UNIVERSIDADE DE SÃO PAULO

FACULDADE DE FILOSOFIA, LETRAS E CIÊNCIAS HUMANAS

DEPARTAMENTO DE LETRAS CLÁSSICAS E VERNÁCULAS

PROGRAMA DE PÓS-GRADUAÇÃO EM FILOLOGIA E LÍNGUA PORTUGUESA

MANUELE BANDEIRA DE MENEZES

A adaptação de empréstimos recentes no papiamentu moderno

(VERSÃO CORRIGIDA) 
UNIVERSIDADE DE SÃO PAULO

FACULDADE DE FILOSOFIA, LETRAS E CIÊNCIAS HUMANAS

DEPARTAMENTO DE LETRAS CLÁSSICAS E VERNÁCULAS

PROGRAMA DE PÓS-GRADUAÇÃO EM FILOLOGIA E LÍNGUA PORTUGUESA

\section{A adaptação de empréstimos recentes no papiamentu moderno} (VERSÃO CORRIGIDA)

Dissertação apresentada ao Programa de PósGraduação em Filologia e Língua Portuguesa do Departamento de Letras Clássicas e Vernáculas da Faculdade de Filosofia, Letras e Ciências Humanas da Universidade de São Paulo, para a obtenção do título de Mestre em Filologia e Língua Portuguesa. Essa dissertação é uma versão corrigida, o exemplar original se encontra disponível no CAPH da FFLCH (Centro de Apoio à Pesquisa Histórica).

Orientador: Prof. Dr. Gabriel Antunes de Araujo 


\section{Sumário}

Agradecimentos ................................ vi

Resumo ................................

Abstract ................... ix

Lista de Abreviaturas e Símbolos . . . . . . . . . . . . . . . . . . x

1 Introdução 1

1.1 Formação do corpus . . . . . . . . . . . . . . . . . . . . 2

1.1 .1 Metodologia ..................... 6

1.2 O papiamentu e Curaçao . . . . . . . . . . . . . . . . . . . 10

1.2 .1 Origens do papiamentu . . . . . . . . . . . . . . 14

2 Papiamentu... 18

2.1 Papiamentu: fonologia . . . . . . . . . . . . . . . . . . . . 19

2.1.1 Sistema vocálico . . . . . . . . . . . . . . . . . . . . . . 19

2.1 .2 A distribuição de vogais . . . . . . . . . . . . . . . . . . 21

2.1.3 Sistema consonantal . . . . . . . . . . . . . . . . . 22

2.1.4 A distribuição das consoantes nasais . . . . . . . . . . . . . . 24

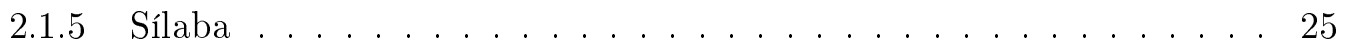

2.2 Acento e tom . . . . . . . . . . . . . . . . . . . 28

2.3 Grafia: aspectos gerais . . . . . . . . . . . . . . . . . . 30

2.4 Prefixos e Sufixos . . . . . . . . . . . . . . . . . . 40

2.5 Estudos prévios . . . . . . . . . . . . . . . . . . . . . 43

2.5.1 Papiamentu: estudos linguísticos prévios . . . . . . . . . . 43

3 Adaptação de Empréstimos $\mathbf{5 2}$

3.1 Empréstimo: correntes teóricas . . . . . . . . . . . . . . . . 54

3.1.1 Adaptação através da percepção . . . . . . . . . . . . . . . . . 59

3.1 .2 Adaptação através da produção . . . . . . . . . . . . . . . . 61

3.1.3 Adaptação através da percepção e produção . . . . . . . . . . . . . 65

3.1.4 Adaptação baseada na similaridade perceptual . . . . . . . . . . 66

4 Análise dos dados $\quad 69$

4.1 Fontes lexicais . . . . . . . . . . . . . . . . . . . 70

4.2 As restrições na nativização/adaptação de empréstimo . . . . . . . . . . 74

4.3 Processos segmentais . . . . . . . . . . . . . . . . . . 80

4.3.1 Ensurdecimento . . . . . . . . . . . . . . . . . 80

4.3 .2 Palatalização . . . . . . . . . . . . . . . . . . . . . . . 82

4.3 .3 Falsa iotização . . . . . . . . . . . . . . . . . . 83

4.3 .4 Velarização . . . . . . . . . . . . . . . . . . 84

4.3 .5 Assimilação . . . . . . . . . . . . . . . . . . . . . . . . . 84

4.3 .6 Nasalização . . . . . . . . . . . . . . . . . . . . . . . . . 86

4.3 .7 Alçamento . . . . . . . . . . . . . . . . . 86 
4.3.8 Falso betacismo . . . . . . . . . . . . . . . . . 87

4.3 .9 Aférese . . . . . . . . . . . . . . . . . . . 88

4.3 .10 Síncope . . . . . . . . . . . . . . . . . . . . 89

4.3 .11 Apócope . . . . . . . . . . . . . . . . . . . 90

4.3 .12 Redução de ditongo . . . . . . . . . . . . . . . . . . . . . 92

4.3 .13 Epêntese . . . . . . . . . . . . . . . . . . 93

4.3 .14 Metátese . . . . . . . . . . . . . . . . . . 94

4.4 Ressilabificação . . . . . . . . . . . . . . . . . . . . 95

4.4.1 A existência do $/ \mathrm{v} /$ no papiamentu . . . . . . . . . . . . . . 95

4.4 .2 Vogais arredondadas . . . . . . . . . . . . . . . . . 98

4.5 Processos morfológicos . . . . . . . . . . . . . . . . . . . 98

4.6 Variação lexical . . . . . . . . . . . . . . . . . . . . . . . . . 102

4.7 Algumas observações sobre a grafia . . . . . . . . . . . . . . . . . . . 104

4.8 Síntese . . . . . . . . . . . . . . . . . . . 106

5 Considerações Finais $\quad 111$

6 Referências bibliográficas $\quad 115$

$\begin{array}{ll}\text { A Corpus } & 121\end{array}$ 
"Mais do que qualquer outra problemática, as opiniões sobre a introdução de palavras

estrangeiras parecem induzir a posições pessoais e provocar pareceres que vão muito além de qualquer modo de ver puramente linguístico". Wolfgang Roth 


\section{Agradecimentos}

A minha mãe, Marluce, e irmão, Pedro, pelo carinho, amor e por todo o apoio que me foram dados: conselhos, sugestões e firmeza nos momentos em que precisei, sendo muito mais que uma família, verdadeiros incentivadores. Ao meu pai, por ser também um sustentáculo e por ter me dedicado seu afeto.

Agradeço ao professor Dr. Gabriel Antunes de Araujo pela orientação, sempre vigilante e atenciosa, contribuindo de forma incalculável na discussão dos dados e na elaboração de toda a pesquisa. Agradeço não só a Gabriel, mas a Daniela, Olivia e Pedro Crocco, por terem cedido um cantinho da sua casa e dos seus corações, sendo mais do que amigos, uma família.

A Barbara Perquin e Epifanio Claresa por terem me recebido em Curaçao com tanto cuidado e atenção, buscando facilitar ao máximo minha estadia na ilha. Agradeço a Monica Armenta, por sua amizade e ajuda. A professora Luisette Sambo e aos alunos da University of Curaçao, por terem me auxiliado na coleta e gravação dos dados. Aos profissionais da Biblioteca Mongi Maduro que, tão gentilmente, me cederam seu material bibliográfico.

A todos os meus professores, pelo conhecimento e, em especial, ao professor Dr. Paulo Chagas pelas sugestões e observações para o melhor desenvolvimento do estudo. Agradeço também à banca examinadora, constituída pela professora Dra. Gladis Massini-Cagliari e pelo professor Dr. Mario Viaro, que me ofereceu importantes contribuições acerca do trabalho e seus possíveis desdobramentos

Gostaria de agradecer ao Grupo de Estudos de Linguas em Contato (GELIC) e aos membros de audiência de todos os encontros acadêmicos dos quais eu participei pelas intervenções valiosas que tanto aprimoraram a pesquisa. Agradeço especialmente aos doutorandos Antônio Félix de Souza Neto e Shirley Freitas, pela leitura atenta e pelas sugestões para o meu estudo.

A professora Dra. Márcia Oliveira, pela preocupação e pelo carinho que, durante toda a minha estadia em São Paulo, tem dispensado a mim.

A minha amiga/irmã, Shirley Freitas, pela sua amizade perene. Faltam-me palavras para agradecer a uma pessoa que tanto me apoiou e ainda me apoia. Shika, saiba que seu auxílio no campo pessoal e profissional foram fundamentais para a realização do trabalho.

Desejo agradecer a todos os meus amigos soteropolitanos que, mesmo longe, souberam se fazer perto, especialmente a Tamires, a Laila, a Karlinha, a Carine, a Andrea e a Liliane. Aos amigos feitos em Sampa que tanto me deram apoio e estímulo; agradeço especialmente a Edu, Gabi, Aninha Fred, Nati, Livia, João, Sassá, por formarem juntos comigo uma linda família de nômades. Gostaria de agradecer especialmente a Aluísio por todo o apoio e incentivo que me ofereceu. 
Ao Conselho Nacional de Desenvolvimento Cientifico e Tecnológico (CNPq) pela concessão da bolsa de mestrado através da qual a pesquisa foi viabilizada. Agradeço também à Universidade de São Paulo (USP), pelo seu incentivo à pesquisa e ao conhecimento.

Enfim, muito obrigada por viabilizarem essa experiência tão enriquecedora e de grande importância para a minha formação como pesquisadora.

É importante salientar que todas as pessoas que ajudaram ou leram o meu trabalho não são, de forma alguma, responsáveis pelos eventuais erros que permanecerem. 


\section{Resumo}

No presente estudo, são investigados os processos fonológicos e morfológicos na adaptação/nativização de itens lexicais, incorporados no século XX, provenientes de outras línguas (sobretudo do espanhol, holandês, inglês e português) para o papiamentu moderno, língua falada nas ilhas de Aruba, Bonaire e Curaçao por mais de 200 mil pessoas. A partir do corpus formado pela seleção de aproximadamente mil palavras de nativização recente, este trabalho limitou-se aos domínios lexicais do Esporte, Política, Economia, Tecnologia e Desenvolvimento. A escolha teve por objetivo limitar os dados obtidos para apenas itens de empréstimos recentes, ou seja, constituir um corpus com palavras incorporadas a partir do século XX em diante. O material utilizado para pesquisa foi retirado de fontes como manuais e livros de esporte (DANIELS, 1986; PERSAUD, 1992; COSTER, 2010); guias e livros sobre politica e economia (HOYER, 1944; SINDIKATONAN, 1985; HEILIGERSHALABI, 1988; KOMERSIO, 1996); jornal impresso Extra (2011), produzido e vendido em Curaçao; dicionário bilíngue papiamentu/inglês (RATZLAFF-HENRIQUEZ, 2008). A análise de itens lexicais de adaptação recente buscou avaliar se os empréstimos são nativizados segundo o padrão linguístico do papiamentu ou se há uma gramática especial para estas palavras (PARADIS \& LABEL, 1994; PARADIS, 1996; KENSTOWICZ, 2001; KENSTOWICZ \& SUCHATO, 2004) e também buscou identificar os padrões fonológicos e morfológicos existentes na adaptação. Para realizar tais propósitos, os itens lexicais coletados das fontes escritas foram gravados com pelo menos dois falantes nativos (para cada palavra). Posteriormente, deu-se início ao processo de análise de dados que foi baseado em padrões de correspondência de som entre palavras do papiamentu e palavras de empréstimo de outras línguas. Foram coletados 930 itens relativos ao empréstimo recente. Desse número total, pôde-se traçar, em 892 palavras, uma única língua fonte, enquanto que 38 itens ou são palavras resultantes do processo de hibridismo, em que o item lexical é formado por palavras fontes de duas ou mais línguas ou possuem mais de um étimo possível. Ao analisar os números obtidos pelo espanhol e português em todos os campos lexicais, constata-se que tais línguas são as que mais participam no processo de empréstimo de itens lexicais para o papiamentu. Esse predomínio sinaliza que o papiamentu moderno ainda é influenciado pelas línguas que formaram o seu superstrato, embora não se possa ignorar a presença de um número significativo de itens de étimo holandês e inglês na formação de seu vocabulário recente. Tendo como embasamento teórico a Teoria de Restrições e Estratégias de Reparo (TCRS), proposta por Paradis (1988) e a Teoria da Similaridade Perceptual (STERIADE, 2002; FLEISCHHACKER, 2001, 2002; WALKER 2003), o estudo confirmou que a informação segmental tende a ser maximamente preservada. O apagamento não foi o recurso mais usado, ocorrendo apenas quando era necessário evitar a violação de uma restrição na L1. Além disso, os falantes tendem a maximizar a similaridade perceptual entre a forma adaptada e o input estrangeiro nos processos de empréstimo.

Palavras-chave: Papiamentu moderno; Adaptação; Empréstimo; Padrões de adaptação; Similaridade. 


\section{Abstract}

This study investigates the phonological and morphological processes involved in the adaptation/nativization of lexical items from other languages (especially Spanish, Dutch, English, and Portuguese) incorporated during the twentieth century into modern Papiamentu, a language spoken on the islands of Aruba, Bonaire and Curaçao by over 200 thousand people. Based on a corpus made up of a selection of approximately a thousand recently nativized words, the study limits itself to the lexical domains of Sport, Politics, Economics, Technology, and Development. The choice aimed to limit data obtained to only items of recent loans, that is, the aim was to constitute a corpus of words incorporated from the twentieth century onwards. The material used for the study was taken from sources such as sports manuals and books (DANIELS, 1986; PERSAUD, 1992; COSTER, 2010); guides and books on politics and economics (HOYER, 1944; SINDIKATONAN, 1985; HEILIGERSHALABI, 1988; KOMERSIO, 1996); the newspaper Extra (2011), produced and sold in Curaçao; and a Papiamentu/English bilingual dictionary (RATZLAFF-HENRIQUEZ, 2008). The analysis of recently adapted lexical items seeks to evaluate whether the loanwords studied were nativized according to the linguistic patterns of Papiamentu, or if there is a special grammar for these words. (PARADIS \& LABEL, 1994; PARADIS, 1996; KENSTOWICZ, 2001; KENSTOWICZ \& SUCHATO, 2004) and it also seeks to identify the existing phonological and morphological patterns in the adaptation. In order to achieve these aims, the lexical items collected from the written sources were recorded by at least two native speakers (for each word). Then, a process of data analysis was initiated, based on patterns of sound correspondence between Papiamentu words and loanwords from other languages. A total of 930 items were collected in relation to recent loans. Of these, a single language source can be traced in 892 words, while 38 items are either words formed by hybridism, in which the lexical item is formed by source words from two or more languages, or words with more than one possible etymon. In the analysis of the numbers obtained relating to Spanish and Portuguese in all the lexical fields, it can be seen that these two languages are the ones with the largest part in the process of loaning of lexical items to Papiamentu. This predominance indicates that modern Papiamentu continues to be influenced by the languages that framed its superstratum, although the presence in recent Papiamentu vocabulary of a significant number of items with Dutch and English etymons should also not be ignored. Taking as a theoretical framework the Theory of Constraints and Repair Strategies (TCRS), proposed by Paradis (1988) and the Theory of Perceptual Similarity (STERIADE, 2002; FLEISCHHACKER, 2001, 2002; WALKER 2003), this study attests that segmental information tends to be maximally preserved. Deletion was not the most commonly used resource, apparently occurring only when there was a need to avoid violation of a restriction in the L1. Additionally, speakers tend to maximize the perceptual similarity between the adapted from and the foreign input in the loan processes.

Keywords: Modern Papiamentu; Adaptation; Loanwords; Patterns of adaptation; Similarity. 


\section{Lista de Abreviaturas e Símbolos}

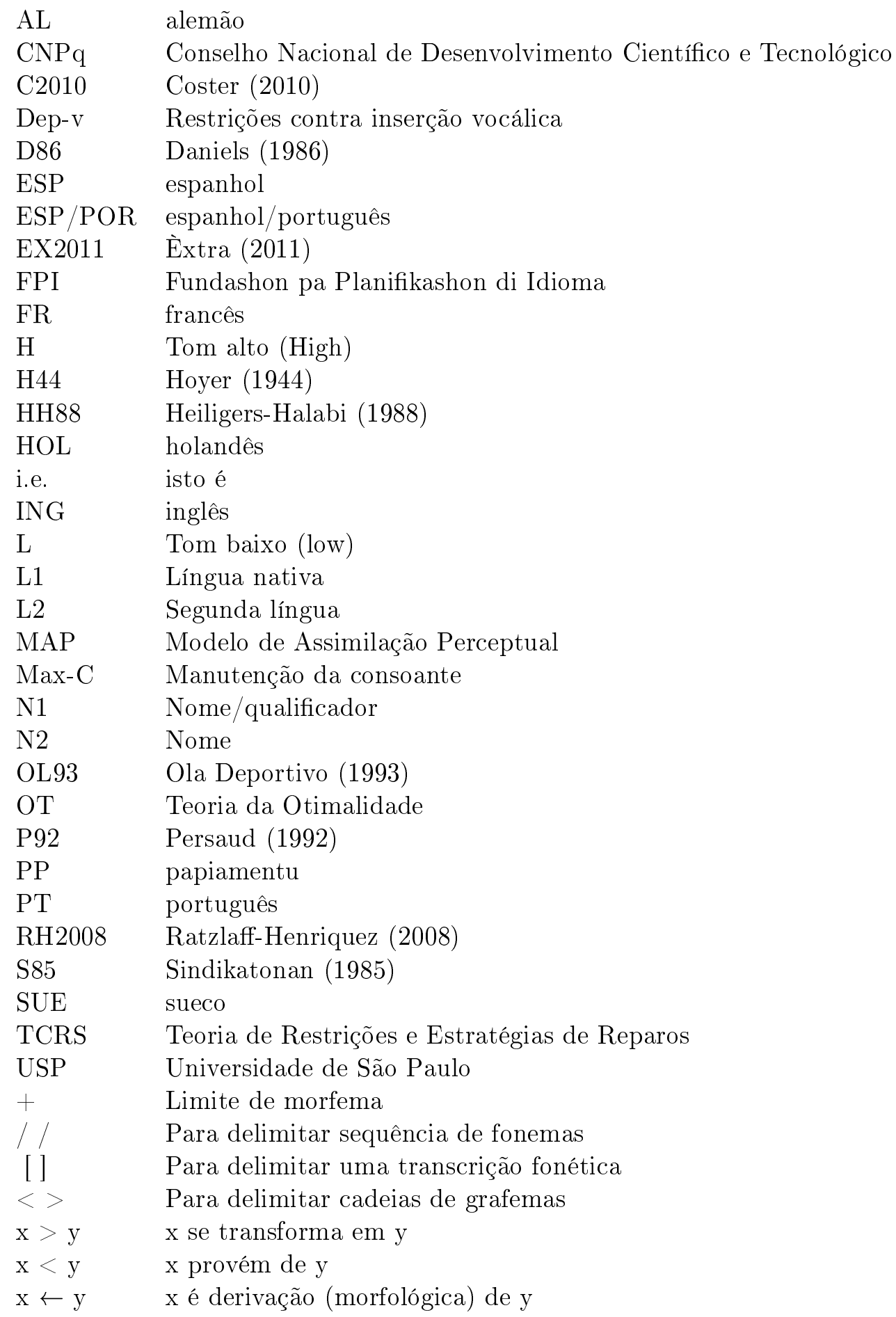




\section{Lista de Tabelas}

2.1 Vogais . . . . . . . . . . . . . . . . . . 20

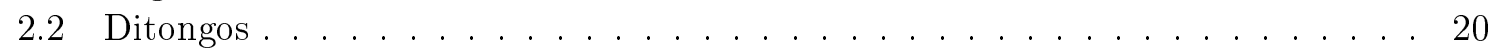

2.3 A distribuição das vogais . . . . . . . . . . . . . . . . . . . . 22

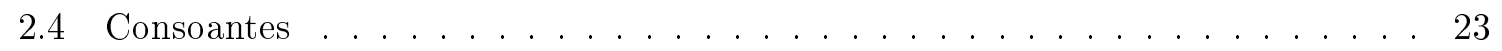

2.5 A distribuição das consoantes nasais . . . . . . . . . . . . . . 25

2.6 A distribuição do cluster no papiamentu . . . . . . . . . . . . . . . 27

2.7 Clusters na coda. . . . . . . . . . . . . . . . . . . . . 28

2.8 Exemplos de palavras que sofreram hispanização segundo Martinus (1990). . . . 34

4.1 Prováveis fontes lexicais de empréstimo do papiamentu . . . . . . . . . . . . 71

4.2 Itens com mais de um étimo possível . . . . . . . . . . . . . . . . . 71

4.3 Palavras adaptadas ao papiamentu que sofrem pouca ou nenhuma alteração. . . 75

4.4 Itens lexicais do espanhol que foram submetidos ao processo de apagamento do

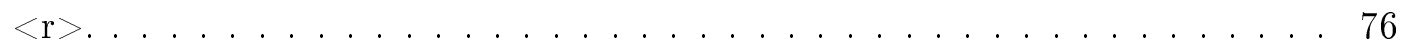

4.5 Processo de ensurdecimento de obstruintes sonoras. . . . . . . . . . . . . 79

4.6 Exemplos de palavras em variação no papiamentu. . . . . . . . . . . . . . . 103

4.7 Processos de adaptação encontrados na análise dos dados. . . . . . . . . . . . 108 


\section{Capítulo 1}

\section{Introdução}

O presente estudo busca investigar os processos fonológicos e morfológicos na adaptação/nativização de palavras originadas de outras línguas (sobretudo do espanhol ${ }^{1}$, holandês, inglês e português ${ }^{2}$ no papiamentu moderno ${ }^{3}$ com os seguintes objetivos: (i) avaliar se os empréstimos são nativizados segundo o padrão linguístico do papiamentu ou se há uma gramática especial para estas palavras (PARADIS \& LABEL, 1994; PARADIS, 1996; KENSTOWICZ, 2001; KENSTOWICZ \& SUCHATO, 2004); (ii) identificar os padrões fonológicos e morfológicos existentes na adaptação de empréstimos no papiamentu.

\footnotetext{
${ }^{1}$ Nem sempre é possível definir se uma palavra é de origem espanhola ou portuguesa no papiamentu, assim preferiu-se adotar o termo espanhol/português. Segundo Birmingham (1970 apud LIPSKI, 2008), cerca de sessenta por cento do léxico do papiamentu tem origem no espanhol ou no português. Por exemplo, hasi "fazer", bieu "velho", mucho "muito", traha "trabalhar" são de origem espanhola, ao passo que bai "vai", trese "trazer", nasementu "nascimento" e papia "falar" são de origem portuguesa. Contudo há palavras, como frio "frio", largu "longo" e boka "boca", que podem ser originárias de qualquer uma das duas línguas ibéricas. Quando não era possível saber se a palavra era proveniente do espanhol ou do português, preferiu-se usar a nomenclatura espanhol/português.

${ }^{2}$ Não se pode afirmar com precisão qual português teve e ainda tem contato com o papiamentu. Sabe-se que a companhia holandesa Shell, em 1915, ao se instalar em Curaçao, levou para a ilha trabalhadores do mundo todo, incluindo países como o Brasil e Portugal. Devido aos fatores históricos, como a presença provável de judeus sefarditas lusofalantes que saíram de Pernambuco, após a expulsão dos holandeses, em direção a Curaçao; a fatores geográficos, como a proximidade física; e às relações comerciais existentes, o português do Brasil seria o candidato natural, no entanto não se pode descartar a possibilidade de influência do português europeu.

${ }^{3}$ Em Aruba, emprega-se uma grafia etimológica e, em Curaçao, uma grafia de motivação fonológica. Assim, o dialeto de Aruba, por exemplo, restringe /u/ para a posição não final de palavra e tem /o/ no que o dialeto de Curaçao tem / $\mathrm{u} /$ final de palavra, como em papiamento/papiamentu. Desse modo, o primeiro mantém -o final na grafia oficial do país, enquanto que o último preserva o -u no mesmo contexto em sua grafia. Além dessa distinção, existem inúmeras outras, como a diferença entre o $<\mathrm{c}>$, comum na escrita de Aruba, e o $<\mathrm{k}>$, comum na grafia de Curaçao.
} 
A partir de um corpus composto por itens lexicais incorporados a partir da segunda metade do século XX, analisar-se-ão palavras pertencentes aos campos lexicais de Esporte, Política, Economia, Tecnologia e Desenvolvimento. Serão investigadas alterações fonológicas e morfológicas nos itens lexicais das línguas emprestadoras para a língua-alvo (o papiamentu). Tal estudo é importante, pois a nativização de palavras de origem estrangeira é, como afirmam Calabrese \& Wetzels (2009), um locus privilegiado para a observação do funcionamento do sistema linguístico da língua receptora. Ao investigar como o papiamentu adapta palavras emprestadas, é possível também analisar como a dada língua funciona sob uma abordagem linguística sincrônica.

Para realizar tal intento, este capítulo introdutório será disposto da seguinte maneira: na seção 1.1 e na subseção 1.1.1, serão descritas as fontes a partir das quais o material foi coletado para essa pesquisa, assim como o método utilizado, respectivamente; na seção 1.2, poderá ser visto um breve histórico de Curaçao, assim como o status político da antiga Antilhas Holandesas; por fim, em 1.2.1, serão apresentadas as hipóteses sobre as possíveis origens do papiamentu.

\subsection{Formação do corpus}

Os dados utilizados para esse estudo foram compostos por palavras dos seguintes campos lexicais: Esporte, Política, Economia, Tecnologia e Desenvolvimento4. A escolha por esses campos lexicais tem por objetivo formar um corpus de adaptação recente, ou seja, coletar palavras incorporadas a partir do século XX.

Uma das principais razões para se investigar um corpus formado por palavras de adaptação recente se deve ao fato de que tais palavras podem demonstrar os processos de

\footnotetext{
4 Tecnologia e Desenvolvimento foram considerados como um campo lexical único, uma vez que possuem um recorte lexical muito próximo, até mesmo semelhante em alguns aspectos.
} 
nativização sincrônica no papiamentu. Assim, dois objetivos primordiais guiaram essa investigação: (i) investigar os processos fonológicos e morfológicos de adaptação/nativização de empréstimos recentes no papiamentu moderno; (ii) avaliar se os empréstimos são nativizados segundo o padrão linguístico do papiamentu ou se há uma gramática especial para estas palavras (PARADIS \& LABEL, 1994; PARADIS, 1996; KENSTOWICZ, 2001; KENSTOWICZ \& SUCHATO, 2004).

O material utilizado para essa pesquisa foi retirado das seguintes fontes: manuais e livros de esporte (DANIELS, 1986; PERSAUD, 1992; COSTER, 2010); guias e livros sobre política e economia (HOYER, 1944; SINDIKATONAN, 1985; HEILIGERS-HALABI, 1988; KOMERSIO, 1996); jornal impresso Èxtra (2011), produzido e vendido em Curaçao; dicionário bilíngue papiamentu/inglês (RATZLAFF-HENRIQUEZ, 2008). Todos os materiais supracitados foram escritos em papiamentu. Foram utilizados, como base de dados, livros e manuais sobre Esporte, Política e Economia. Em relação ao Esporte, três manuais usados para o corpus abordavam temáticas distintas: o primeiro trata dos fundamentos básicos para a prática do beisebol (DANIELS, 1986); o segundo é referente ao Comitê Olímpico Internacional (PERSAUD, 1992); e o último trata da Copa do Mundo da FIFA 2010, organizada pela FIFA (COSTER, 2010).

Daniels (1986) escreve um dos primeiros manuais em papiamentu para iniciantes do beisebol. Nesse manual, são dadas informações básicas sobre o esporte, tais como: a maneira como o campo de beisebol se divide; os nomes dos jogadores e das possíveis jogadas; o regulamento e as penalidades existentes.

No manual elaborado por Persaud (1992), são abordados os jogos olimpícos. Ao falar sobre o Comitê Olímpico Internacional, Persaud (1992) traz, em seu manual, dados históricos sobre as Olimpíadas, os esportes praticados desde o início da realização dos jogos, países que sediaram o torneio, a polêmica em torno do dopping, entre outras coisas. Por 
fim, em FIFA Kopa Mundial 2010 i su anfitrión ("Copa do Mundo da FIFA 2010"), Coster (2010) aborda, de forma breve, as principais informações referentes ao torneio de futebol mundial, organizado pela FIFA, ocorrido na África do Sul, no ano de 2010, tais como: times participantes, tabelas de jogos, cidades que sediaram os jogos, escalações das seleções, os jogadores que melhor atuaram no torneio etc.

Quanto aos manuais e livros a respeito de Política, foram utilizadas duas fontes. A primeira consiste em um pequeno guia inglês-papiamentu escrito por Hoyer (1944). Esse guia oferece listas de vocabulário básico em papiamentu, as listas mais significativas para esse estudo foram as listas sobre cargos políticos. A segunda fonte se trata de um manual escrito por grupos de sindicalistas de Curaçao, Na kaminda pa un era nobo: Alternativa sosio-ekonómiko di sindikatonan uni di Korsou ("No caminho para uma nova era: alternativa sócio-econômica de sindicatos unidos de Curaçao"). Nesse guia, os sindicalistas discutem possíveis alternativas políticas e econômicas que deveriam ser reivindicadas.

No tocante à Economia, foi utilizado um guia para empresários de pequenas empresas. O guia escrito por Bernadette Heiligers-Halabi (1988) dá orientações para os procedimentos nos primeiros estágios para formação do negócio. Um guia semelhante ao de Halabi sobre economia é o manual, intitulado: Bon Komèrsio. Mas trabou. Mihó Kòrsou ("Bom comércio. Mais trabalho. Melhor Curaçao"). Nesse manual (KOMERSIO, 1996), são discutidos os benefícios para o povo curaçolenho ao desenvolver de forma eficiente suas atividades econômicas, como o turismo.

Para a busca por itens de todos os campos lexicais, utilizaram-se o Dicionário papiamentu-inglês de Betty Ratzlaff-Henriquez (2008) e o jornal Èxtra (2011). O Èxtra foi fundado em março de 1976. Sua primeira edição possuía apenas dez páginas. Após mais de trinta anos, o jornal hoje apresenta 56 páginas em sua edição. O Ėxtra é formado por uma equipe de dez jornalistas, dentre esses, há um jornalista especial para o esporte e 
outros para notícias internacionais, provenientes da agência de notícias Associated Press e traduzidas e adaptadas para o papiamentu (HISTORIA, 2007).

De acordo com as informações fornecidas através do site do jornal, todos os jornalistas submetem seu texto aos corretores (em papiamentu, korektris) via e-mail. Após as correções e o processamento gráfico, o jornal vai para a impressão. Todos os dias, o Ėxtra finaliza o jornal por volta das três da manhã (HISTORIA, 2007). A maioria dos membros do jornal fez cursos que visam "aprimorar" as habilidades de escrever em papiamentu segundo a grafia oficial. Sobre esse aprimoramento em relação à escrita, nas palavras do próprio Ėxtra: "[..] a maioria de nós fez cursos para aprender a escrever em papiamentu segundo a grafia, assim o povo que tem que aprender sua língua bem e escrever de forma ótima pode usar nosso jornal para saber como fazer isso da melhor maneira possível." ${ }^{5}$ (HISTÓRIA, 2007). Essa afirmação do Ėxtra merece atenção, uma vez que o jornal atribui a si a tarefa pedagógica de ensinar a grafia da língua.

O Dicionário papiamentu-inglês de Betty Ratzlaff-Henriquez, desde sua primeira publicação em 1992, já foi submetido a duas reedições e, por mais de quinze anos, tem sido um guia de referência importante para cidadãos locais e negociantes que lidam com o mundo falante de inglês, bem como para os recém-chegados às ilhas de Aruba, Bonaire e Curaçao (ilhas ABC) (RATZLAFF-HENRIQUEZ, 2008). A presente pesquisa utilizou, como base para coleta de vocábulos, a segunda edição do referido dicionário. Tal edição contém 20.000 palavras com um adendo de mais de cem entradas adicionais, omitidas na primeira edição.

\footnotetext{
5 “[...] mayoria di nos a bai kursonan pa siña skibi papiamentu segun ortografia, ya asina e pueblo ku tin di siña su lenga bon i skibié optimal por usa nos korant pa sa kon ta hasi esaki mihó posibel."
} 


\subsubsection{Metodologia}

Tendo apresentado de forma geral o corpus do estudo, resta descrever como os dados obtidos foram analisados pela pesquisa. Primeiramente, houve o levantamento de dados, em que, a partir das fontes citadas anteriormente, foram selecionados os vocábulos pertencentes aos campos de Esporte, Política, Economia, Tecnologia e Desenvolvimento.

Após o levantamento, as palavras foram divididas nos seus respectivos campos lexicais. Em seguida, os itens lexicais coletados das fontes escritas foram gravados com pelo menos dois falantes nativos (para cada palavra). No processo de gravação, as palavras foram lidas pelos falantes, a partir da escrita, de forma isolada. As gravações com falantes nativos de papiamentu foram necessárias para se verificar os processos fonéticos na nativização. Além disso, uma determinada palavra pode ser escrita de uma forma não prevista no sistema gráfico da língua. Desta maneira, muito embora a grafia do papiamentu de Curaçao seja de inspiração fonológica, ou seja, o sistema é baseado, mormente, no princípio 'um fonema, um grafema', há exceções (cf. RATZLAFF-HENRIQUEZ, 2008). Por exemplo, uma palavra como vershon pode ser escrita com o grafema $<\mathrm{v}>$, porém pode ser realizada foneticamente com [f] ou [b], uma vez que o segmento fricativo labiodental sonoro em papiamentu ainda não é comum na fala de todos os habitantes de Curaçao.

Posteriormente, iniciou-se o processo de análise de dados que foi baseado em padrões de correspondência de som entre palavras do papiamentu e palavras de empréstimo de outras línguas. Um exemplo ${ }^{6}$ de como funcionaria a análise baseada em um padrão de correspondência pode ser visto no item lexical geplaatst kapitaal ${ }_{291}$ "capital emitido" encontrado no papiamentu. Ao buscar, em outras línguas, vocábulos relacionados a tal significado, verifica-se que, no holandês, há essa mesma forma gráfica também referente a

\footnotetext{
${ }^{6}$ Todos os itens pertencentes ao corpus e citados ao longo da dissertação terão um número subscrito que indica sua localização no apêndice.
} 
“capital emitido" (geplaatst kapitaal). Uma vez que não há, em outras línguas investigadas, o mesmo vocábulo ou algo semelhante, define-se a fonte lexical da referida palavra. Nesse caso, o holandês. Contudo nem sempre foi possível definir com segurança a fonte lexical das palavras coletadas, sobretudo, devido à semelhança de vocábulos e forma fonológica entre determinadas línguas. Como, por exemplo, a palavra coach "técnico", adaptada para o papiamentu, que pode ser proveniente tanto do holandês, quanto do inglês, haja vista que ambos possuem tal palavra em seu léxico. E mesmo se formos comparar a realização fonética desse vocábulo no papiamentu e nas duas línguas citadas, tal comparação não dirime a imprecisão da fonte lexical, uma vez que a pronúncia nas três línguas é bastante similar.

Assim, após a coleta de dados e atribuição da palavra fonte ${ }^{7}$, a etapa seguinte para a investigação constituiu-se em estabelecer algumas regras a que palavras emprestadas pareciam estar sujeitas quando entram no léxico do papiamentu. Por exemplo, tem-se a palavra bateadó 37 "batedor", do espanhol bateador. Ao comparar a palavra fonte e a adaptada, percebe-se que houve o apagamento do -r final (apócope). Ao observar os nomes terminados em - dor que foram adaptados para o papiamentu, percebe-se que todos, sem exceção, sofrem o processo de apócope. Dessa forma, pode-se concluir que o apagamento do -r final no segmento - dor é uma regra da língua nativa (L1), que é aplicada às palavras provenientes de empréstimo que possuem tal segmento.

Ao analisar esses empréstimos, este estudo também buscou identificar a língua fonte para a palavra nativizada em papiamentu. Tarefa de difícil execução, uma vez que a

\footnotetext{
${ }^{7}$ O sentido de palavra fonte está ligado ao conceito definido por Viaro (2011: 99) acerca de étimo: "[...] é a forma equivalente da mesma palavra, imediatamente anterior numa sincronia pretérita qualquer." Viaro (2011) também faz uma distinção importante entre étimo e origem. Segundo o autor, quando se afirma que um dado item é de étimo francês, por exemplo, indica-se que o item foi emprestado dessa língua e, a partir dela, correspondentes em outras línguas foram formados. Dessa maneira, percebe-se que investigar o étimo das palavras não é o mesmo que pesquisar a origem do item.
} 
semelhança de um mesmo vocábulo em duas línguas diferentes nem sempre significa empréstimo, como afirma Viaro (2011: 98): "Dadas duas línguas quaisquer, se um elemento de seu vocabulário é parecido ou idêntico, tanto no significante, quanto no significado, isso pode dever-se basicamente a três fatores distintos: coincidência, empréstimo ou origem comum."

A coincidência formal, segundo Viaro (2011), é um fenômeno muito comum. O autor dá como exemplo dessa coincidência o nome para "olho" que, em grego moderno, é máti e, em malaio, mata. Contudo essa semelhança não reflete uma origem comum entre essas línguas, pois, ao se investigar o passado à procura de documentos ou valendo-se de outras línguas afins, constata-se que não houve empréstimo. Em relação a esse último conceito, Viaro afirma:

O empréstimo ocorre quando línguas estiveram comprovadamente em contato direto, envolvendo ou não bilinguismo (como ocorreu com o português e o espanhol nos séculos XVI e XVII) ou quando uma delas teve algum prestígio e influência cultural e, nesse caso, não supõe necessariamente contiguidade espacial (como com o português e o italiano no século XVI ou com o francês em toda a história do português até o início do século XX). De fato, é preciso observar que algumas línguas como o francês e o inglês tiveram ampla difusão por todo o mundo e muitas vezes os étimos são ligados a elas. (grifo do autor) (VIARO, 2011:99)

E, por último, há a semelhança por origem comum, um dos objetos de estudo frequente da Etimologia. Assim, tendo em vista que os falantes do papiamentu conviveram e ainda convivem em um ambiente multilinguístico ${ }^{8}$, estando as seguintes línguas muito presentes:

\footnotetext{
8 Para identificar as línguas que tiveram maior contato com o papiamentu e, por essa razão
} contribuíram para a formação do seu léxico, é necessário pensar sobre os segmentos sociais que 
espanhol, holandês, inglês e português, sendo a última língua mais recorrente no passado

histórico da ilha, a análise buscou correspondências de som entre palavras dessa língua

crioula e das línguas supracitadas. É importante salientar que nem sempre apenas esse

procedimento é suficiente para afirmar com precisão a língua emprestadora de cada item

lexical, assim o estudo poderá ser revisto no momento em que houver maiores pesquisas

na área.

Embora seja difícil atribuir a origem lexical de alguns itens analisados, a dificuldade

pode se tornar menor se as condições do contato e das influências possíveis forem ana-

lisadas. Mesmo que o papiamentu tenha recebido contribuições do espanhol, holandês,

inglês, português e francês em sua formação, pode-se dizer que as línguas que hoje têm

mais contato com o papiamentu moderno são o espanhol, holandês e inglês ${ }^{9}$. Assim, as

faziam parte da sociedade curaçolenha dos primeiros séculos (XVII e XVIII). Segundo Andersen (1974), havia dois grupos distintos no que tange à colaboração de itens lexicais. O primeiro grupo se constituiria por participantes ativos na sociedade de Curaçao (os holandeses, os judeus e os escravos africanos); já o segundo grupo seria constituído por participantes que tinham um papel marginal e passivo na sociedade de Curaçao (marinheiros visitantes, soldados, comerciantes e negociantes, padres falantes de espanhol do continente, traficantes). Além disso, é preciso lembrar das situações em que residentes de Curaçao tiveram contato com falantes de outras áreas do Caribe, América Latina e Holanda e consequentemente adquiriram vocabulário dessas pessoas (tal contato ocorre com muita frequência mesmo atualmente, o que explica a forte presença de vocábulos do inglês, hoje uma língua internacional de comunicação).

Quanto à contribuição de itens lexicais do holandês para o papiamentu, de acordo com Wood (1970), a grande maioria dos empréstimos veio de dialetos não-padrão do século XVII falados por soldados, marinheiros, comerciantes e artesãos etc. Palavras de origem hispânica foram introduzidas igualmente por pessoas do nordeste da Espanha e Portugal - pessoas que falavam catalão, galego etc. Também se deve mencionar o papel relevante do espanhol latino-americano - empresários e padres do continente e das ilhas do Caribe, mas provavelmente em maior número os trabalhadores, marinheiros, comerciantes e traficantes que falavam espanhol não-padrão. Essa influência de áreas falantes de espanhol da América Latina e Caribe tem crescido consideravelmente durante os últimos 150 anos, o que torna difícil avaliar a importância do espanhol latino-americano, como oposto às línguas e dialetos do nordeste da Espanha e Portugal, sem mencionar o papel do português, na formação do vocabulário nativo do papiamentu.

Segundo Andersen (1974), o que todos os possíveis colaboradores de itens lexicais para o papiamentu têm em comum são as relações de transação e comércio que dominaram Curaçao e que dependeram de um amplo número de trabalhadores de classes inferiores e, por outro lado, de um pequeno número de supervisores. Assim, é possível especular que o léxico inicial do papiamentu foi constituído dessa gama de atividades que se permeavam na interação de principalmente judeus e outras pessoas em posições similares (talvez principalmente os holandeses), juntamente com as massas de classes econômicas inferiores, falantes de holandês, espanhol, português, galego, catalão etc. e um amplo número de escravos africanos.

${ }^{9}$ A presença desses diferentes segmentos sociais e culturais resultou hoje em um multilinguismo em Curaçao, já notado na década de setenta por Lessa (1975): 
incertezas acerca da fonte lexical terminam por se restringir se a palavra é proveniente do holandês ou inglês, como no caso da palavra $\operatorname{coach}_{921}$ "técnico"; ou se a palavra é proveniente do espanhol ou português, como a palavra atleta $_{561}$, por exemplo. Não ocorreu uma única vez a situação da origem de uma palavra poder ser atribuída às quatro línguas. Foi encontrada apenas uma palavra proveniente do francês.

Após o estabelecimento das mudanças fonológicas e morfológicas a que as palavras de adaptação recente foram submetidas, o passo seguinte foi organizar os vocábulos em formato de tabelas. Foram coletados 930 dados distribuídos nos quatro campos lexicais, já citados. Cada palavra foi apresentada em formato de tabela. Quanto à organização das tabelas, na primeira coluna, tem-se a forma gráfica, baseada na grafia oficial de Curaçao, e sua transcrição fonética. Na segunda coluna, tem-se a possível palavra fonte do empréstimo em itálico seguida pela língua fonte provável do item. Na terceira coluna, apresenta-se o significado do item. E, por fim, na quarta coluna, a fonte da qual foi retirada a palavra. As palavras pertencentes ao corpus foram divididas por língua fonte (espanhol, holandês, inglês, espanhol/português e português) e organizadas em ordem alfabética (ver apêndice A).

\subsection{O papiamentu e Curaçao}

A ilha de Curaçao está localizada no sul do mar do Caribe, próximo à Costa da Venezuela.

De acordo com os primeiros resultados do Censo de 2011, realizado pelo Central Bureau

Eles falam normalmente várias línguas. O holandês, no qual aprendem a ler, o inglês, veículo universal de comunicação, o espanhol, tradição que vem do século XVI e instrumento diário de entendimento com turistas sul-americanos e em particular com o turista, o comerciante e o embarcado venezuelanos, de grande presença em todo o Caribe. (LESSA, 1975: 11)

De acordo com Lessa (1975: 14), no final do século XIX, houve um intenso período de influência cultural venezuelana (as ilhas estão a menos de 100 quilômetros do continente). A partir de 1914, a revolução econômica trazida pelas refinarias de petróleo não só identificou melhor Curaçao na transação comercial, como favoreceu o contato com outras línguas, tais como o espanhol. 
of Statistics de Curaçao (STATISTICS, 2012), 150.563 pessoas vivem na ilha, sendo que 68.848 são homens e 81.715 são mulheres. Segundo o Censo, entre o período de 2001 a 2011, houve um aumento de 19.936 pessoas (8.339 homens e 11.597 mulheres). Esse aumento populacional de $15.3 \%$ pode ser atribuído, segundo os pesquisadores, ao aumento natural (número de nascimentos superior às mortes), mas também devido à imigração que significativamente excedeu a emigração durante os últimos dez anos.

O fluxo imigratório entre 2001 e 2011 implicou o aumento do número de pessoas nãonascidas em Curaçao. Segundo o Censo (STATISTICS, 2012), enquanto em 2001, 80.5\% da população tinha nascido em Curaçao, em 2011, esse número caiu para 75.8\%. A porcentagem de pessoas nascidas em qualquer outra ilha das antigas Antilhas Holandesas ou Aruba também caiu de 3.5\%, em 2001, para 2.9\% em 2011. Em contrapartida, o número de pessoas nascidas fora de Curaçao e das antigas Antilhas Holandesas e Aruba tem crescido. Em 2011, pessoas nascidas na Holanda já representavam 6\% da população (comparado ao 4.2\% em 2001). Depois da Holanda, os países que possuem o maior número de migrantes residentes em Curaçao são: a República Dominicana e Colômbia, com 3.6\% e 3.0\% respectivamente. No geral, o número de pessoas nascidas fora de Curaçao cresceu de $19.5 \%$ em 2001 para 24.2\% em 2011. Em suma, os números do fluxo imigratório, no século XXI, indicam que não se pode ignorar a presença significativa de pessoas que certamente não são falantes de papiamentu como os holandeses (6\%), dominicanos (3.6\%), colombianos (3\%), haitianos (1.2\%), venezuelanos (1\%) e jamaicanos $(0.7 \%)$.

No Censo de 2011, os entrevistados foram questionados sobre a língua que mais falavam em seus lares. Os resultados revelaram que o papiamentu é falado na maioria das casas, com $78.4 \%$, seguido pelo holandês (9.5\%), espanhol (6.1\%), inglês (3.5\%) e outras línguas (2.4\%). De acordo com os números obtidos pela Central Bureau of Statistics (2012), em 2001, a média de casas em que se falava papiamentu era de $80.3 \%$. O que nos leva a concluir 
que, além do leve declínio do número de lares com falantes de papiamentu nos últimos dez anos, a porcentagem de lares com falantes de outras línguas tem crescido (STATISTICS, 2012).

Em relação à educação, o número de pessoas que frequentam uma escola cresceu de 36.122, em 2001, para 39.483 em 2011. Além disso, em 2011, 96.1\% das pessoas jovens entre 4 e 18 anos (idade relativa à educação compulsória segundo o Censo) estava frequentando a escola, número quase idêntico ao obtido em 2001 (95.7\%). O Censo de Curaçao (STATISTICS, 2012) afirma que, segundo a UNESCO, a média de participação escolar para educação básica (4-13 anos) na região da América Latina e Caribe é de 94\%. Comparado à região, a média de participação escolar de Curaçao, para a mesma faixa, de $98.9 \%$ pode ser descrita como excelente.

Quanto à sua formação histórica, sabe-se que Curaçao esteve sob dominação espanhola no período de 1499 até 1634, embora tenha sido ocupada minimamente por espanhóis durante esse período. Em 1634, quando os holandeses tomaram a ilha, havia apenas trinta e dois espanhóis e cerca de mil quatrocentos indígenas segundo Navarro (1951: 188). Os espanhóis e a grande maioria dos indígenas desocuparam a ilha em direção ao continente. De acordo com Wijk (1958: 176), os índios que chegavam ao continente falavam um "puro espanhol".

Em 1635, permaneciam na ilha apenas setenta e cinco indígenas (NAVARRO, 1951: 188). Em outubro daquele ano, havia 462 habitantes em Curaçao: sendo 412 europeus e 50 indígenas (ANDERSEN, 1974). De acordo com Navarro (1951: 188), em 1695, todos os índios tinham desaparecido de Curaçao, contudo alguns historiadores acreditam que havia ainda índios vivendo na ilha durante um bom tempo.

Em 1638, havia apenas oito escravos africanos em Curaçao, mas, após o ano de 1641, com o estabelecimento de Curaçao como entreposto de escravos, um amplo número de 
escravos começou a chegar à ilha. Além do contingente escravo, é preciso salientar a entrada dos judeus em Curaçao. A partir de 1650 e em diante, um número significativo de judeus falantes de português se estabelece na ilha (KARNER, 1968: 9-10). A maioria deles veio de territórios que foram dominados outrora por holandeses no Nordeste brasileiro. E muitos desses judeus chegavam diretamente do Brasil ou por meio de Amsterdam. Para Lessa (1975), a presença do português está relacionada ao estabelecimento dos judeus luso-falantes na ilha no século XVII.

Em 1700, segundo Hartog (1968: 134), havia 2.400 escravos e um número grande de escravos particulares. Os escravos, em pouco tempo, eram maioria se comparados aos europeus. O comércio de escravos persistiu até 1778 (LAUFFER, 1971: 13 apud ANDERSEN, 1974).

Em relação a seu status político, o papiamentu hoje é falado nas ilhas de Aruba, Bonaire, Curaçao, São Martinho (Saint Maarten), Santo Eustáquio, Saba e na Holanda. Até 1986, tais ilhas faziam parte da federação das Antilhas Holandesas (VAN ALLER, 1994; HILLEBRINK, 2008 apud ARAUJO, 2011). Em 1996, a ilha de Aruba passou a ser oficialmente um país, mas dentro do Reino dos Países Baixos. No ano de 2010, as Antilhas Holandesas deixaram de existir com a declaração do estatuto de nação por São Martinho e Curaçao. Quanto às ilhas de Bonaire, Saba e Santo Eustáquio, elas se tornaram municipalidades da Holanda. Assim, o Reino dos Países Baixos passou a ser constituído por quatro países no dia dez de outubro de 2010: Holanda, Aruba, Curaçao e São Martinho. O Reino possui quatro línguas oficiais: o holandês, o inglês (língua veicular em São Martinho, Saba e Santo Eustáquio), o frísio e o papiamentu (língua veicular em Aruba, Curaçao e Bonaire) (ARAUJO, 2011). 


\subsubsection{Origens do papiamentu}

Há basicamente quatro hipóteses no que diz respeito à gênese do papiamentu. A primeira afirma que ele pode ser resultado de uma relexificação de um proto-crioulo afro-português, como acreditam Lenz (1928) e Martinus (1996). A segunda hipótese supõe que o papiamentu seria genuinamente um crioulo de base portuguesa, formado em Curaçao, no final do século XVII, devido à chegada de judeus sefarditas, falantes do português, provenientes do nordeste brasileiro, acompanhados, por sua vez, de escravos (SMITH, 1999). Finalmente, a terceira hipótese defende que o papiamentu era originalmente um crioulo de base espanhola, cujos elementos portugueses foram trazidos pelos judeus sefarditas (Cf. MUNTEANU, 1996). Jacobs (2009) apresenta, entretanto, uma quarta possibilidade: o nascimento do papiamentu na ilha de Santiago, no arquipélago de Cabo Verde, seguida pela migração para Curaçao.

Segundo Araujo (2011), as hipóteses que defendem a existência de um proto-crioulo afro-português, no século XV, e o surgimento das línguas crioulas de base portuguesa tendo como causa o mesmo proto-crioulo se baseiam em semelhanças lexicais e gramaticais entre os vários crioulos de origem portuguesa. Essa hipótese foi primeiramente formulada por Naro (1978 apud ARAUJO, 2011), que defendia o desenvolvimento de um pidgin afroportuguês em Lisboa, no século XV, em comunidades onde se reuniam os primeiros escravos de procedência africana.

Paul Teyssier (1959) chamava tal variedade de Língua de Pretu, já para Naro, Língua de Reconhecimento. Tal Lingua de Reconhecimento era utilizada pelos navegadores europeus nos primeiros anos da colonização da região da Alta Guiné e do Golfo da Guiné. Há, contudo aspectos que os estudiosos defensores de tal proto-crioulo não conseguiram explicar de forma eficiente, aspectos esses que são discutidos por Araujo (2011): 
Aprendida pelos escravos portugueses, este proto-crioulo foi relexificado (crioulizado) pelas populações escravizadas e difundido, todas as vezes em que os escravos eram transplantados. Se, de fato, o proto-crioulo foi uma língua emergencial (um pidgin), com pouca complexidade gramatical, a coincidência entre as semelhanças do sistema de tempo, aspecto e modo entre os crioulos de Santiago (Cabo Verde) e de Bissau (Guiné-Bissau) não pode ser explicada pela nativização do proto-crioulo, posto que falantes de outras línguas teriam que, aleatoriamente, fazer as mesmas escolhas gramaticais encontradas nestas variedades (ARAUJO, 2011: 15).

Assim, de acordo com Jacobs (2009), as similaridades entre os crioulos da Alta Guiné, em um ponto da África, e do Golfo da Guiné, em outro ponto, evidenciam que os crioulos se desenvolveram independentemente, mesmo com a base lexical portuguesa, sendo transmitidos por falantes nativos. Para Araujo (2011:15), deve ter existido uma Língua de Reconhecimento em Lisboa, no século XV, contudo esta língua não reuniu condições sócio-históricas favoráveis para o desenvolvimento como uma língua crioula, não havendo fatos comprobatórios de que ela tenha sido levada às regiões insulares coloniais portuguesas no Atlântico.

Em relação à segunda hipótese, sabe-se que, com a tomada da ilha de Curaçao em 1634 até a expulsão dos holandeses de Pernambuco em 1650, um grande número de judeus sefarditas imigrou para Curaçao, levando consigo escravos de casa e de campo (ARAUJO, 2011). Os escravos eram provenientes de territórios portugueses da costa atlântica da África e, após permanecerem por um tempo em Pernambuco, possuíam um contato com o português.

A língua falada pela comunidade imigrante sefardita ainda é uma questão em aberto e não consensual entre os pesquisadores. Para Joubert \& Perl (2007: 48 apud ARAUJO, 
2011), é difícil saber precisamente que língua era falada por essa comunidade sefardita, embora Emmanuel (1957) tenha mostrado que, das 2.500 lápides do antigo cemitério judaico de Willemstad, 1.668 lápides foram escritas em português e a mais antiga lápide esculpida na referida língua data de 1685. Para Araujo (2011: 16), tais lápides seriam uma evidência de que o português teria alto prestígio na comunidade, "ao ponto de ser a língua transmitida ao futuro, em memória do desaparecido". Em contrapartida, para Maurer (1986:98), mesmo que o português circulasse na comunidade sefardita, o número de escravos, seja de casa ou de campo, geralmente não passava de $15 \%$ do total de escravos na ilha.

Sobre a afirmação de Maurer, Araujo (2011) oferece um contra-argumento, chamando atenção para o prestígio da comunidade sefardita, sua relação com os escravos negociados no varejo e o impacto linguístico dos escravos ladinos dos sefarditas nos escravos novos (boçais). Além disso, é preciso reconhecer também, segundo Araujo (2011), o papel das amas-de-leite negras na criação das crianças judaicas e demais crianças brancas de alta classe. Quanto ao uso do papiamentu pela comunidade sefardita, a ausência de descrições acerca do português da comunidade, especialmente a variedade do século XVII e sua relação com o papiamentu, impede uma conclusão, uma vez que não há provas empíricas (ARAUJO, 2011).

Em relação à possibilidade de o papiamentu ser um crioulo de base espanhola, Mcwhorter (1995) defende que não é possível ter havido crioulos de base espanhola no Atlântico. Segundo o estudioso, o papiamentu não pode possuir tal base, uma vez que os espanhóis, por estarem limitados pelo Tratado de Tordesilhas, não puderam criar condições sóciohistóricas necessárias para o surgimento de línguas crioulas no Atlântico Ibérico. Além disso, o interesse da colonização espanhola na América dos séculos XVI e XVII eram as riquezas minerais, não o comércio de escravos. Diante disso, apenas na segunda metade 
do século XVII, os espanhóis criam as condições para o surgimento de línguas crioulas, como, por exemplo, o palenquero, na cidade de Palenque de San Basílio na Colômbia. De qualquer modo, Lipski (2008) argumenta que a influência atual da língua espanhola no papiamentu torna difícil investigar com exatidão a fonte dos vocábulos portugueses no papiamentu (ARAUJO, 2011).

Por fim, Jacobs (2009) defende, com base em características linguísticas e históricas, que a origem do papiamentu está relacionada à região da Alta Guiné. Como argumento, Jacobs mostra que as características semelhantes compartilhadas pelo papiamentu, pelo crioulo de Santiago, em Cabo Verde, pelo crioulo guineense e por algumas línguas da África Ocidental somente são explicadas quando se analisa a estadia do crioulo de Santiago na cidade de Cachéu (na Guiné Bissau), fundada por uma comunidade originária de Santiago e falante do crioulo santiaguense (ARAUJO, 2011). Dessa maneira, sob influência do Mandinga e do Wolof, este crioulo (ou proto-crioulo) foi, em seguida, levado, juntamente com seus falantes, para Curaçao, transplantando consigo traços santiaguenses.

Como se pôde observar, há centros de desacordo com relação à origem do papiamentu. Todas as hipóteses, contudo compartilham a base ibérica de seu léxico, sobretudo portuguesa, sendo influenciada pelo espanhol dos séculos XVII e XVIII. Segundo Holm (2004), o papiamentu apresenta um léxico ibérico parcialmente reestruturado por não se tratar de uma língua crioula típica de uma plantation ou de um quilombo e por estar separado geograficamente e politicamente da base lexical que contribuiu para sua origem.

Após a discussão acerca da história de Curaçao, formação do papiamentu e descrição do corpus e método utilizado; o universo de observação do estudo, o papiamentu, será o foco principal do próximo capítulo. Assim, a seguir, veremos como essa língua crioula se estrutura fono e morfologicamente; os principais estudos linguísticos realizados sobre essa língua; bem como se estrutura sua grafia. 


\section{Capítulo 2}

\section{Papiamentu}

O objetivo deste estudo é investigar os processos fonológicos e morfológicos de adaptação de palavras provenientes de outras línguas (espanhol, holandês, inglês, espanhol/português e português) para o papiamentu moderno. A questão de diferentes línguas terem atuado na formação dessa língua não altera o fato de que o papiamentu é "uma língua bem definida com sua própria característica e identidade fonológica" (MARTINUS, 1990: 138). Kouwenberg \& Muysken (1995: 218) afirmam que, embora o papiamentu seja uma língua já conhecida e relativamente bem descrita, ainda não há um estudo padrão em inglês que lide plenamente com a complexidade da língua. Maurer (1988), segundo os autores, trabalha com o tempo, modo e aspecto de forma bastante detalhista. Sobre o estudo de Dijkhoff (1993), Kouwenberg e Muysken (1995) definem como um estudo significativo acerca da morfologia nominal, já para Kouwenberg \& Murray (1994), seria útil um esboço geral. Desde 1995, o quadro pouco se modificou, não havendo ainda uma descrição completa da fonologia do papiamentu. Tal descrição torna-se assim uma meta importante para os estudos sobre o papiamentu que deve ser alcançada nos próximos anos.

De acordo com Holm (2000: 64), o desafio mais básico para os crioulistas do século XXI é escrever descrições linguísticas e socioculturais de todas as línguas pidgin e crioulas 
conhecidas, bem como de seus dialetos. Assim, descrever os processos fonológicos e morfológicos da adaptação de palavras de outras línguas para o papiamentu permitirá contribuir para a ampliação do entendimento sobre as línguas crioulas em geral.

Visando contribuir para a aumento do conhecimento acerca da fonologia e morfologia do papiamentu, o presente estudo requer que, primeiramente, seja exposto o que já se sabe no tocante aos níveis da língua supracitados, o que será visto nas próximas seções. Assim, na seção 2.1, serão apresentados aspectos no tocante à fonologia do papiamentu, como o sistema vocálico (seção 2.1.1), a distribuição de vogais (seção 2.1.2), o sistema consonantal (seção 2.1.3), a distribuição das consoantes nasais (seção 2.1.4) e a sílaba (seção 2.1.5). Na seção 2.2, será descrito, brevemente, a atribuição de acento e tom. Em 2.3, aspectos da grafia e sua padronização serão analisados. Na seção 2.4, serão discutidos algumas questões acerca dos prefixos e sufixos. Por fim, na seção 2.5, serão apresentados alguns dos estudos linguísticos mais relevantes sobre o papiamentu.

\subsection{Papiamentu: fonologia}

As características gerais com relação à fonologia do papiamentu serão expostas a seguir. As próximas seções serão apresentadas na seguinte ordem: primeiramente, o sistema vocálico. Em seguida, a distribuição das vogais, posteriormente será descrito o sistema consonantal e sua distribuição. Por fim, a estrutra silábica da língua.

\subsubsection{Sistema vocálico}

O papiamentu possui sete vogais /i/, /e/, / $/ /, / \mathrm{a} /, / \mathrm{\jmath} /, / \mathrm{o} /, / \mathrm{u} /$, que são comuns aos sistemas vocálicos dos crioulos de base portuguesa da África Ocidental (MAURER, 1995). Muitas palavras de origem holandesa, contudo apresentam vogais arredondadas ${ }^{10}[\mathrm{y}, \varnothing]$. O

${ }^{10}$ Cf. Kouwenberg \& Murray (1994: 6). 
estatuto do quadro vocálico do papiamentu é controverso na literatura, uma vez que alguns autores desconsideram as vogais arredondadas anteriores (cf. LENZ, 1928; HARRIS, 1951; DIJHKOFF, 1993; LIPSKY, 2008), afirmando que a ocorrência de tais vogais seriam provenientes de empréstimos ou devido ao contato linguístico com o holandês, o inglês e o espanhol. A distribuição das vogais pode ser vista na Tabela 2.1:

Tabela 2.1: Vogais

$$
\begin{array}{ccc}
\mathrm{i} & (\mathrm{y}) & \mathrm{u} \\
\mathrm{e}, \varepsilon & (\varnothing) & \text { o, } \supset
\end{array}
$$

a

A Tabela 2.2, elaborada a partir do que propõem Harris (1951) e Kouwenberg \& Murray (1994), apresenta os ditongos que podem ocorrer no papiamentu ${ }^{11}$. O primeiro elemento vocálico nesses ditongos é silábico. O segundo elemento é a contraparte nãosilábica das vogais altas $/ \mathrm{i} / \mathrm{ou} / \mathrm{u} /$. O contraste entre as vogais médias posterior e anterior é neutralizado nos contextos de ditongo. Os segmentos que se encontram entre diples $(<>)$ referem-se ao formato gráfico dos ditongos.

Tabela 2.2: Ditongos

$\begin{array}{ccc}\text { V1: anterior } & & \text { iw }<\text { iu }> \\ & \text { ej }<\text { ei }> & \text { ew }<\text { eu }> \\ & (\varnothing j)<\mathrm{uii}> & \\ \text { V1: posterior } & \text { oj }<\text { oi }> & \text { ow }<\text { ou }> \\ & \text { uj }<\text { ui }> & \\ \text { V1: baixa } & \text { aj }<\text { ai }> & \text { aw }<\text { ou }>\end{array}$

11 O papiamentu ainda não possui uma descrição completa de todos os ditongos possíveis na língua. Embora Kouwenberg \& Murray (1994) e Harris (1951) demonstrem uma tentativa de delineamento do inventário dos ditongos, em algumas palavras como prueba "prova", residuo "resíduo" e kontinuo "contínuo", percebe-se que o papiamentu possui mais encontros vocálicos do que o previsto pelos autores, o que sinaliza a necessidade de maiores estudos acerca desses segmentos. 
Um exemplo do ditongo formado por $<$ ai $>$ [aj] pode ser visto nas palavras bai "ir", gai "galo", tai "cintura" e baiskel "bicicleta". O ditongo escrito graficamente como < ou $>$ pode ser pronunciado de forma similar como [ow] (dou ['dow] "dado" e tou ['tow] "rebocar"), mas pode ser pronunciado também como [aw]12: blou ['blaw] "azul", kòrsou ['kohsaw] "Curaçao", rou ['xaw] "manhã". O ditongos formado por [oj] <oi > encontra-se em palavras como roi ['xoj] "riacho", hoi ['hoj] "feno" e ploi ['ploj] "trança ou placa". O ditongo <ei $>$

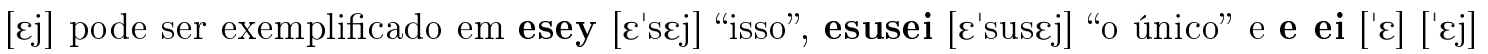
"aquele". O ditongo <eu $>$ [ew] encontra-se em itens lexicais como leu ['lew] "distante", breu ['brew] "alcatrão" e kangreu ['kãgrew] "caranguejo". O ditongo [iw] <iu > pode ser visto em friu ['friw] "frio", riu ['xiw] "rio", hudiu [hu'diw] "judeu" e skiu ['skiw] "tímido, temeroso". Em relação ao ditongo formado por [øj] -ùi pode ser encontrado em itens como brùit ['brøjt] "noiva" e flùit "assobio" ['fløjt]. Por fim, o ditongo formado por [uj] -ui pode ser visto em palavras como brui ['bruj] "fritar ovos", pui ['puj] "picar" e fui ['fuj] "expressão de descontentamento".

\subsubsection{A distribuição de vogais}

As restrições fonotáticas são de dois tipos: restrições na distribuição de vogais individuais e restrições com relação à coexistência de vogais em palavras. Por exemplo, em palavras de duas sílabas, há uma restrição na combinação das vogais que podem ocorrer na mesma palavra (ver Tabela ${ }^{13}$ 2.3).

A tabela demonstra que as vogais médias frontais mais altas e mais baixas encontramse em distribuição complementar: as vogais [e] e [ə] não podem aparecer combinadas em

12 Talvez essa realização do ditongo esteja relacionado à influência do holandês na pronúncia dos falantes nativos de papiamentu, uma vez que, em holandês, por exemplo, 'azul' é pronunciado como blauw ['blaw].

${ }^{13}$ Essa tabela foi baseada no estudo de Kouwenberg \& Murray (1994). 
Tabela 2.3: A distribuição das vogais

\begin{tabular}{|l|l|l|}
\hline $\begin{array}{l}\text { Meio da } \\
\text { palavra }\end{array}$ & Final de palavra /e, $\boldsymbol{\varepsilon} /$ & Final de palavra /o, $\mathbf{o} /$ \\
\hline$/ \mathrm{i} /$ & firme "firme" & dicho "provérbio" \\
\hline$/ \mathrm{e} /$ & debe "dívida" & eko "eco" \\
\hline$/ \varepsilon /$ & prèkè "alfinete" & - \\
\hline$/ \mathrm{a} /$ & dande "canção de ano novo" & ganso "ganso" \\
\hline$/ \mathrm{J} /$ & - & bòngò "mármore grande" \\
\hline$/ \mathrm{o} /$ & morde "morder" & boto "barco" \\
\hline$/ \mathrm{u} /$ & muhé "mulher" & busto "busto" \\
\hline
\end{tabular}

uma mesma palavra em associação com as vogais $[\varepsilon]$ e [o]. Além disso, a vogal [u] não ocorre em uma palavra com -e $[\varepsilon]$ final, exceto quando essa vogal recebe acento (muhé [mu'he] "mulher").

Segundo Kouwenberg \& Murray (1994:7), as vogais anteriores arredondadas são as mais severamente restritas e uma explicação possível estaria em transformações muito recentes. Elas, geralmente, ocorrem em palavras monossilábicas do holandês e do inglês e estão frequentemente em variação com vogais não-arredondadas. Tal domínio restrito dessas vogais pode indicar duas possibilidades: (i) talvez as vogais arredondadas não pertencem ao inventário fonológico do papiamentu, ou seja, tais vogais não seriam distintivas para os falantes nativos e são, por essa razão, restritas às palavras de empréstimo do holandês, tais como: hür [hyr] "alugar, aluguel" e brug [brøx] "ponte"; ou (ii) tais vogais estão sendo introduzidas no inventário fonológico muito recentemente e, por essa razão, ainda não são tão comuns. Segundo Souza Neto (em preparação), é possível encontrar realizações de vogais arredondadas em itens com mais de uma sílaba (ver subseção 4.4.2).

\subsubsection{Sistema consonantal}

O sistema consonantal do papiamentu é formado por dezoito consoantes, considerando fonemas. Os símbolos na Tabela 2.4 são os mesmos do IPA (International Phonetic 
Alphabet) ${ }^{14}$; símbolos gráficos, se diferentes, são dados em parênteses. Todas as consoantes têm status fonêmico.

Tabela 2.4: Consoantes

\begin{tabular}{|l|l|l|l|l|l|l|}
\hline & Labial & Dental & $\begin{array}{l}\text { Alveo- } \\
\text { palatal }\end{array}$ & Palatal & Velar & Glotal \\
\hline \hline Oclusivas & $\mathbf{p}, \mathbf{b}$ & $\mathbf{t}, \mathbf{d}$ & & & $\begin{array}{l}\mathbf{k}, \mathbf{g} \quad(\mathrm{g}, \\
\mathrm{gu})\end{array}$ & \\
\hline Fricativas & $\mathbf{f}(\mathbf{v})^{15}$ & $\mathbf{s}, \mathbf{z}$ & $\begin{array}{l}\mathbf{f}(\mathrm{sh}, \mathrm{si}) \\
\mathbf{3}\end{array}$ & & $\mathbf{x}(\mathrm{g})$ & $\mathrm{h}$ \\
\hline Africadas & & & & & & \\
\hline Nasais & $\mathbf{m}$ & $\mathbf{n}$ & & $\mathbf{n}(\tilde{\mathrm{n}})$ & & \\
\hline Líquidas & & $\mathbf{l}, \mathbf{r}$ & & & & \\
\hline
\end{tabular}

Quanto à representação gráfica das obstruintes, a oclusiva velar sonora é escrita como $<$ gu $>$ antes de vogais anteriores, por exemplo sigui "seguir", guepi "peixe guppy ou lebiste (Poecilia reticulata)", e como $<\mathrm{g}>$ em outros contextos, como: gordo "gordo". A fricativa velar é também representada graficamente como $\langle\mathrm{g}>$. Ela ocorre no início de sílaba antes de vogais anteriores não-arredondadas, por exemplo, general"general" e pagina "página", e final de palavra, como: lèg "deitar, tirar uma soneca" (KOUWENBERG \& MURRAY, 1994).

Já a fricativa [J] é representada graficamente pelo $<$ sh $>$, como em shimis "vestidos". Na grafia, busca-se diferenciar também o som de [j] e [t $\left.\int\right]$, o primeiro, como dito, representa-se através do -sh e o segundo é representado pelo $<\mathrm{ch}>$ como em chapi ([t]]api) "prateleira" e karpachi (karpa[t]]i) "crânio". O som fricativo [3] é representado graficamente com o segmento <zj> como em zjilea ([3]ilea) "geléia" zjurnalismo 890 ([3]ornalismo) "jornalismo". O segmento gráfico $<$ dj $>$ é utilizado para representar o som africado [d3], como em djóp ([d3]óp) "trabalho" e indjan (in[dz]an) "indiano".

${ }^{14}$ Os símbolos fonéticos utilizados pelo estudo correspondem ao padrão IPA, exceto no que tange à transcrição das semivogais que, nesse estudo, são registradas como [j] e [w].

15 Sobre o estatuto fonêmico do /v/, ver subseção 4.4.1. 
Em relação aos segmentos nasais, o som palatal [n] pode ser representado pelo $<\tilde{n}>$, como em ñapa ([n]apa) e ñetu ([n]etu) "neto". A nasal alveolar [n] (pèn (pè[n]) "caneta") e a nasal velar [y] (pan (pa[y]) "pão") são representadas com um único grafema $<\mathrm{n}>$.

Ao analisar o sistema e estudos acerca do papiamentu, pode-se dizer que ainda não há um consenso se tal língua contém ou não a série de fonemas fricativos sonoros. Tal série ocorre de forma marginal e é encontrada em poucas palavras. O que ocorre, na maioria das vezes quando um nativo pronuncia uma palavra com um segmento da referida série fonológica, é uma adaptação dessa série. Tal adaptação implicará a escolha por uma série sonora, mas com outro ponto de articulação. Por essa razão, muitas palavras contêm a invariante /f/ ou /b/ (prifatisashon-pribatizashon "privatização" / solfensia - solbensia "solvência"), que derivam historicamente do /v/ das línguas lexificadoras.

\subsubsection{A distribuição das consoantes nasais}

As consoantes nasais podem ocorrer nas posições de onset e coda, como se pode ver na Tabela $^{16}$ 2.5. Como se pôde observar, o som nasal bilabial $[\mathrm{m}]$ pode aparecer na posição de ataque no início da palavra (midi) e em posição medial (cama). Mesmo em posição de coda, o segmento tem seu ponto de articulação preservado, mantendo-se bilabial, seja em posição medial (lampi) ou no final da palavra (róm). A nasal alveolar [n] pode ser prevista na posição de onset no início da palavra, como em nada, ou em posição medial (duna). Tal segmento também aparece em posição de coda medial (lanta) ou em coda final de palavra (hoben).

O número de palavras que contém a nasal palatal é reduzido no papiamentu, especialmente na posição inicial de palavra (ñèñè "vinho"). Alguns estudiosos, a exemplo de

${ }^{16}$ Os exemplos foram retirados de Kouwenberg \& Murray (1994). 
Tabela 2.5: A distribuição das consoantes nasais

\begin{tabular}{|l|l|l|l|l|}
\hline & Início de palavra & Meio de palavra & Pré-consonantal & Final de Palavra \\
\hline \hline Bilabial m & midi "medir" & kama "cama" & $\begin{array}{l}\text { lampi "lâm- } \\
\text { pada" }\end{array}$ & róm "quarto" \\
\hline \hline Alveolar $\mathbf{n}$ & nada "nada" & duna "dar" & lanta "levantar" & hoben "jovem" \\
\hline Palatal $\mathbf{n}$ & ñèñè "vinho" & liña "linha" & - & - \\
\hline Velar $\mathbf{y}$ & - & - & ranka "puxar" & bòn "bom" \\
\hline
\end{tabular}

Kouwenberg \& Murray (1994), acreditam que n é a realização da consoante dental /n/ e a vogal palatal $/ \mathrm{i} /$.

No final de palavra, o ponto de articulação do -n é sempre velar, exceto em palavras que terminam em [ən], tais como hoben "jovem". Pode-se argumentar que essas palavras contêm apenas a consoante nasal na rima, subjacentemente. O contraste que pode ser observado entre bòn ['bon] "bem" e ['boy] "bom" é devido à adoção de alguns empréstimos holandeses com retenção de uma nasal alveolar final de acordo com Harris (1951) e Kouwenberg \& Murray (1994).

\subsubsection{Sílaba}

Em relação à estrutura silábica, a sílaba mínima consiste de uma vogal (núcleo), como em e "ele/ela", podendo conter também um onset (On) e uma coda, como em bul.pes "chicote". A consoante no onset, seja no início ou no meio da palavra, pode ser qualquer uma das consoantes fonêmicas citadas na Tabela 2.4. Para que fique mais claro, exemplos ${ }^{17}$ de $(\mathbf{a}-\mathbf{e})$.

(a) Oclusivas: /b/ bul.pes "açoite", /p/ pa.ña "roupa", /t/ te.ne "manter", /d/ dan.ki "obrigado", /k/ ku.min.sá "começar", /g/ gal "bile";

${ }^{17}$ Exemplos retirados de Kouwenberg \& Murray, 1994: 9-10. 
(b) Fricativas: /f/ fal.su "falso", /s/ su.ku "açúcar", /x/ gi.ter "regador";

(c) Nasais: /m/ ma.sal "numeroso", /n/ te.ne "manter";

(d) Liquidas: /1/ lim.piá "limpar", /r/ ròm "rum";

(e) Glotal: /h/ ko.hin "almofada".

As possíveis combinações entre os grupos consonânticos no papiamentu são listadas na

Tabela 2.6. Um número significativo desses encontros é formado por dígrafos (sequências gráficas de dois grafemas que representam um único som) (exemplos i-iii).

(i) $<$ sh $>$, fricativa $/ \mathrm{J} /$, como em shimis "vestido";

(ii) $<$ ch $>$, africada /t $\int /$, como em chiste "piada"; $<\mathrm{dj}>$, africada /d3/, como em djaka "rato";

(iii) $<\tilde{\mathrm{n}}>$, a nasal palatal, /n/, como em ñetu "neto".

A representação gráfica tem refletido a correlação demonstrada nos exemplos citados, mas não consistentemente: /si/ pode ser representado por 'sh' ou 'si' na grafia, /ti/ por 'ch' ou 'ti', /di/ por 'dj' ou 'di', /ni/ por 'ñ' ou 'ni'. Exemplos dos dois casos são demonstrados na Tabela 2.5. Foneticamente, esses dígrafos são $\left[\int\right],[\mathrm{tj}] \sim[\mathrm{t} f],[\mathrm{dj}] \sim[\mathrm{d} 3]$, e $[\mathrm{n}] \sim[\mathrm{j}]$, respectivamente. A variação na grafia entre dígrafos e sequências da forma Consoante $+i$ não tem base fonética e pode ser devido à fonte etimológica (espanhol).

A coda da sílaba pode ser preenchida com a maioria dos clusters $\mathrm{CC}^{18}$. As consoantes que podem aparecer na coda são um subconjunto das consoantes fonêmicas da Tabela 2.4.

${ }^{18}$ Segundo Souza Neto (em preparação), é possível encontrar itens que permitem até 4 consoantes além do núcleo, como hèrfst / herfst / "outono", o que mostra que pode haver mais clusters do que os previstos na Tabela $\mathbf{2 . 6}$. 
Tabela 2.6: A distribuição do cluster no papiamentu

\begin{tabular}{|c|c|c|c|}
\hline C1 & C2: líquida & C2: outros & Exemplos \\
\hline $\mathbf{p}$ & $\begin{array}{l}1 \\
\mathrm{r}\end{array}$ & & $\begin{array}{l}\text { supla "assoprar", } \\
\text { presta "emprestar" }\end{array}$ \\
\hline $\mathbf{b}$ & $\begin{array}{l}1 \\
\mathrm{r}\end{array}$ & & $\begin{array}{l}\text { blas "balão" } \\
\text { sembra "semear" }\end{array}$ \\
\hline $\mathbf{t}$ & $\mathrm{r}$ & & traha "trabalho" \\
\hline d & $\mathrm{r}$ & & weldro "solda" \\
\hline $\mathbf{k}$ & $\begin{array}{l}1 \\
\mathrm{r}\end{array}$ & & $\begin{array}{l}\text { klaro "claro" } \\
\text { kriminal "criminal" }\end{array}$ \\
\hline $\mathrm{g}$ & $\begin{array}{l}1 \\
\mathrm{r}\end{array}$ & & $\begin{array}{l}\text { glas "copo" } \\
\text { gritaria "gritaria" }\end{array}$ \\
\hline $\mathrm{s}$ & 1 & $\begin{array}{l}- \\
\mathrm{p} \\
\mathrm{t} \\
\mathrm{k} \\
\mathrm{n} \\
\mathrm{m}\end{array}$ & $\begin{array}{l}\text { sla "mossa" } \\
\text { spera "esperar" } \\
\text { stima "amar" } \\
\text { skak "xadrez" } \\
\text { snechi "fatia" } \\
\text { smak "sabor" }\end{array}$ \\
\hline C1 & $\begin{array}{l}\text { C2: oclu- } \\
\text { siva }\end{array}$ & C3: líquida & Exemplos \\
\hline $\mathrm{s}$ & $\mathrm{p}$ & $\begin{array}{l}1 \\
\mathrm{r}\end{array}$ & $\begin{array}{l}\text { splika "explicar" } \\
\text { sprùit "perder, disparar" }\end{array}$ \\
\hline $\mathrm{s}$ & $\mathrm{t}$ & $\mathrm{r}$ & strepi "linha" \\
\hline $\mathrm{s}$ & $\mathrm{k}$ & $\begin{array}{l}1 \\
\mathrm{r}\end{array}$ & $\begin{array}{l}\text { sklabitut "escravidão" } \\
\text { skruf "parafuso" }\end{array}$ \\
\hline
\end{tabular}

O papiamentu não permite obstruintes sonoras na coda. Nos itens de 1-4, há exemplos de coda que possui uma única consoante ${ }^{19}$.

(1) Oclusivas: /p/ teip "tipo", /t/ bèt "aposta", /k/ pik "bico";

(2) Fricativas: /f/ zueif "flutuar", /s/ lès "lição";

19 Exemplos retirados de Kouwenberg \& Murray (1994). 
(3) Nasais: /m/ bòm "bomba", /n/ pin.ta "pintar", len.ga "língua", /n/ final de palavra, como em ha.bon "livre".

(4) Aproximantes: /l/ bèl "sino", /r/ li.ber "livre".

Tabela 2.7: Clusters na coda.

\begin{tabular}{|l|l|l|}
\hline C1 & C2 & Exemplos \\
\hline \hline $\mathbf{r}$ & $\mathrm{p}$ & wèrp "gota" \\
$\mathbf{m}$ & & pòmp "bomba" \\
\hline $\mathbf{k}$ & $\mathrm{t}$ & kontrakt "contrato" \\
$\mathbf{f}$ & & kaft "capa de livro" \\
$\mathbf{~}$ & & test "teste" \\
$\mathbf{l}$ & & vèlt "campo" \\
$\mathbf{r}$ & & spart "respingar" \\
$\mathbf{n}$ & & karènt "uva-passa desi- \\
& & dratada" \\
\hline $\mathbf{l}$ & $\mathrm{k}$ & spalk "tala" \\
$\mathbf{r}$ & & hùrk "atarracado" \\
$\mathbf{n}$ & & krènk "manivela" \\
\hline $\mathbf{( l )}$ & $\mathrm{f}$ & valf "válvula" \\
$\mathbf{r}$ & & dùrf "provocação" \\
\hline $\mathbf{p}$ & $\mathrm{s}$ & djaweps "quinta-feira" \\
$\mathbf{k}$ & & buks "soco" \\
$\mathbf{l}$ & & bals "goma de mascar" \\
$\mathbf{r}$ & & mòrs "vazamento" \\
$\mathbf{m}$ & & dams "senhorita" \\
$\mathbf{n}$ & & stèns "contar (com)" \\
\hline
\end{tabular}

\subsection{Acento e tom}

O acento é, segundo Goilo (1974), importante no que se refere ao papiamentu. Muitas palavras alteram-se semanticamente conforme o acento que levam. Para o estudioso, seria difícil estabelecer uma regra geral de acento em papiamentu, porque haveria muitas exceções, contudo Goilo encontra duas regularizações:

1 Quando a palavra termina em consoante, o acento cai na última sílaba. 
Também as palavras que terminam em $\mathbf{n}$ e $\mathbf{s}$ com exceções naturalmente ${ }^{20}$.

2 As palavras que terminam em vogal levam o acento na penúltima sílaba²1.

(GOILO, 1974: 9)

Segundo Kouwenberg \& Muysken (1995: 207-08), há dois padrões de acento em papiamentu, são eles: paroxítono e oxítono. A paroxítona é um padrão regular para palavras que terminam em vogais ou em $<\mathrm{er}>,<\mathrm{el}>,<\mathrm{em}>$ (em que e representa o schwa em vez de uma vogal plena): kuminda "comida", korda "lembrar", liber "livre". Palavras que terminam em qualquer outra consoante geralmente têm acento na última sílaba: kantor "escritório", kurason "coração", robes "errado". O maior grupo de exceções é composto por verbos de três ou quatro sílabas, que são distintos de outras palavras do mesmo número de sílabas pelo fato de que os verbos geralmente são acentuados na sílaba final; isso é indicado na grafia do papiamentu por meio de um acento agudo: kumindá "cumprimentar", ekiboká "errar" de acordo com Kouwenberg \& Muysken (1995). Há também um número considerável de exceções bissilábicas, tais como: doló "dor", muhé "mulher", mashá "muito", piská "pescar". Através da análise dos dados, observou-se que nem sempre os verbos apresentam o acento na última sílaba, sendo mais comum com verbos de fonte "ibérica". Verbos de étimo holandês, por exemplo, são monossilábicos e não acentuados como skaf $_{366}$ "aplainar" (< schaaf) e spar $_{375}$ "poupar" (< sparen). Segundo Kouwenberg \& Murray (1994: 13-15), os verbos dissilábicos no infinitivo e no presente recebem acento na primeira, já as formas deverbais, sem clíticos, recebem acento na última silaba. Com a presença do clítico, o acento na penúltima sílaba é predominante, tal como em dúna e dunábo.

20 Exemplos: ruman "irmão" e frances "francês".

${ }^{21}$ Exemplos: awa "água", biña "vinho", bibida "bebida". 
Quanto ao sistema tonal, Römer (1991) encontrou tons de nível High e Low que, em muitos - mas não em todos - casos, correspondem a sílabas acentuadas e não acentuadas, respectivamente. Uma classe maior de exceções é formada por verbos bissilábicos. Eles têm padrão High Low com um tom Low realizado na sílaba acentuada, como em pone "colocar", kwèrdè "enrolar", laba "lavar". Há palavras tais como papa "mingau" com um padrão High Low e papa "papai" com padrão tonal Low High (RÖMER, 1991).

Joubert (1991) lista 251 pares de palavras bissilábicas que podem ser distintas apenas pelos seus padrões de tons. Na ampla maioria desses casos (menos que 230), o padrão Low High sobre a palavra bissilábica é um verbo, o padrão High Low é um substantivo: biaja (Low High) "viajar"/[High Low] "viagem", warda [Low High] "esperar, manter, guardar" [High Low] "vigia, guarda". Entretanto, a alternância de tom não pode ser apenas resultado de uma regra derivacional (por exemplo, nominalização através de mudança tonal). Para 85 desses pares, não há relação lexical entre verbo e substantivo: sala [Low High] "saltar"/ [High Low] "sala", para [Low High] "parar"/ [High Low] "pássaro"22.

\subsection{Grafia: aspectos gerais}

Em 1915, G. J. Eybers e Paulus J. Poiesz se destacavam por defender o papiamentu como língua autônoma. Em uma época em que os falantes nativos não se colocavam em defesa da língua crioula, o pastor protestante, Eybers, e o padre católico, Poiesz, holandeses e excelentes utentes do papiamentu, fizeram sua defesa da língua em séries polêmicas no jornal holandês Amigoe di Curaçao (atualmente esse jornal é chamado apenas de Amigoe) (MARTINUS, 1990).

${ }^{22}$ De acordo com a hipótese formulada por Souza Neto (em preparação) acerca do peso silábico, é preciso considerar o étimo e a influência do adstrato, uma vez que processos de ressilabificação têm indicado que predominam os pés troqueu moraicos, cabeça à esquerda conforme os referidos fatores. 
Em contrapartida estava o frei W. J. Walboomers, que defendia a visão de que falantes europeus de uma língua de "cultura", tal como o holandês, não deviam levar a sério uma língua "bruta" como o papiamentu. Para Martinus (1990), o que mais impressiona, ao observar tal polêmica, não seria a postura racista nos argumentos de Walboomers, mas a visão linguística de Eybers. Sua opinião é válida até hoje, uma vez que, em 1915, ele já defendia a ideia de que todas as línguas deveriam ser consideradas iguais se elas oferecem uma adequada comunicação entre seus falantes.

De acordo com Martinus (1990), a defesa do papiamentu por falantes nativos somente aconteceu trinta anos depois, por meio do trabalho de Pierre Lauffer. A atitude dos falantes nativos do papiamentu, seja intelectuais ou populares, no tocante ao papiamentu tem sido sempre dualística e, de certa forma, hesitante segundo Martinus (1990). Sobre tal atitude, Martinus comenta:

On the one hand the language is genuinely cherished by literally everybody and the foreign visitor in the Antilles will often be entertained with: "Nos dushi papiamentu" ("Our beloved papiamentu"), but when it comes to official recognition, they hesitate. This is the case, for example, with the law proposal to make papiamentu an official language in addition to Dutch and the efforts to make papiamentu the language of instruction in schools, which has been the most important issue in education for the last twenty years ${ }^{23}$ (MARTINUS, 1990: 139).

A explicação para essa atitude não é simples. Martinus (1990) afirma que o primeiro

23 Por uma lado, a língua é genuinamente estimada por literalmente todas as pessoas e o visitante estrangeiro nas Antilhas será frequentemente recebido com: "nosso amado papiamentu", mas, no que diz respeito ao reconhecimento oficial, eles hesitam. Esse é o caso, por exemplo, da proposta de lei para tornar o papiamentu uma língua oficial ao lado do holandês e dos esforços para tornar o papiamentu uma língua de instrução nas escolas, que tem sido a questão mais importante na educação pelos últimos vinte anos (tradução nossa). 
fator estaria ligado a razões socioculturais, tais como a longa dominação holandesa; uma outra razão seria o fato de os falantes acreditarem que o meio de comunicação deve ser completamente instrumentalizado, como as línguas europeias em sua maioria, antes que eles possam chamá-lo de língua. Outro fator importante trata-se das visões sobre a origem do papiamentu e sua relação inexorável com a escravidão. Parece difícil aceitar uma herança da escravidão com uma das maiores expressões de sua cultura tanto para quem se considera descendente dos senhores (colonizadores) como para quem pertence à classe de pessoas sem poder.

Segundo Martinus (1990), durante anos, muitos estudiosos evitavam relacionar o papiamentu à teoria do pidgin afro-português, assim tal grupo preferiu aderir à teoria de uma gênese espanhola. O fato de a teoria de um afro-português ter se generalizado nos círculos linguísticos apenas durante os últimos trinta anos ou mais fez com que o conceito do papiamentu como derivação, se não um dialeto do espanhol, influenciasse de forma determinante na padronização e instrumentalização do papiamentu durante a maior parte do século XX (MARTINUS, 1990: 139).

Os escritores da década de trinta que iniciaram a literatura do papiamentu de maneira significativa tinham certeza de que o desenvolvimento dessa língua crioula estava relacionado diretamente ao espanhol. Diante disso, como muitos escritores europeus renascentistas que tinham o Latim ou Italiano como seu ideal, como afirma Martinus (1990), os escritores de trinta não hesitaram em usar o espanhol como modelo de escrita do papiamentu. Tal postura parece ter sobrevida ainda no presente século:

This has remained the habit since then, with the exception of Pierre Lauffer, who died some years ago, and of a small group that he influenced. This habit is more than anywhere else manifest in the four papiamentu daily newspapers which have a total circulation of perhaps thirty thousand. Their journalists 
not only take to the Spanish dictionary when they do not know the word in papiamentu for a certain concept, they often ignore an existing papiamentu term in preference to a Spanish one. (MARTINUS, 1990: 140)24

Para o autor, tal utilização do espanhol como referencial ortográfico tem como consequência uma relexificação de campos semânticos inteiros sem uma necessidade clara. Martinus (1990) dá alguns exemplos dessa relexificação, tais como potrèt, que foi e é uma palavra tradicional para fotografia, porém cada vez mais os jornais têm preferido gráfiko; um agente di polis, que, de termo original, tornou-se um efectivo policial. Nos domínios do futebol e beisebol, em que a terminologia veio do inglês, a hispanização começou a acontecer, o que resultaria em um efeito ridículo segundo Martinus (1990).

Embora Martinus (1990) afirme que a terminologia esportiva referente ao futebol e beisebol tenha vindo do inglês, o presente estudo encontrou exatamente o oposto. Das 335 palavras do corpus de esporte, 201 vocábulos são do espanhol/português, mais de $50 \%$ do total, enquanto o inglês detém $23,2 \%$ do total do léxico esportivo.

A outra razão para a recorrência da hispanização seria devido ao fato de ela ser usada como uma forma de conter a influência do holandês que muitos antilhanos, recém-chegados da Holanda, traziam para o papiamentu. Em alguns momentos, essa prática traz consigo insinuações políticas como um meio, segundo Martinus (1990: 140), "de se libertar do holandês." Tal visão política gera novamente uma substituição de palavras que já eram aceitas. Martinus dá alguns exemplos:

\footnotetext{
${ }^{24}$ Tem permanecido um hábito desde então, com a exceção de Pierre Lauffer, que morreu anos atrás, e um pequeno grupo por ele influenciado. Esse hábito mais do que em qualquer outro lugar se manifesta nos quatro jornais diários de papiamentu que têm circulação total de quase trinta mil (exemplares). Seus jornalistas não apenas usam o dicionário de espanhol quando não sabem a palavra em papiamentu para um certo conceito e frequentemente ignoram um termo existente em preferência a uma palavra em espanhol. (Adaptação nossa.)
} 
Tabela 2.8: Exemplos de palavras que sofreram hispanização segundo Martinus (1990).

\begin{tabular}{|l|l|l|}
\hline Origem - holandês & Palavra hispanicizada & Glosa \\
\hline \hline Dirèkt & Direkto & "Direto" \\
\hline Architèkt & Arkitekto & "Arquiteto" \\
\hline Sport & Deporte & "Esporte" \\
\hline Refri & Arbitro & "Árbitro" \\
\hline Portrèt & Grafiko & "Retrato" \\
\hline
\end{tabular}

As palavras dirèkt e direkto, refri e arbitro, portrèt e grafiko, sport e deporte coexistem ainda hoje no léxico do papiamentu, sendo que todas foram encontradas no livro dedicado à grafia oficial do papiamentu Ortografia i Lista de palabra (FPI, 2009). No caso das palavras architèkt e arkitekto, encontrou-se registro apenas da última, o que nos leva a crer que o item architèkt tenha sido banido, pelo menos, da lista da grafia oficial.

Às vezes, de acordo com Martinus (1990), as palavras que já tinham sido adaptadas ao formato fonológico do papiamentu são emprestadas mais uma vez, supostamente para restabelecer a verdadeira ligação com o espanhol, como estudiante para studiante "estudante"; enseñansa para siñansa "educação"; servicio para serbishi "serviço".

Além da forte orientação em direção ao espanhol no desenvolvimento do papiamentu, há um movimento mais jovem e possivelmente menos poderoso que lutava pela autenticação, começando na década de 1950, com as atividades do poeta Pierre Lauffer (1920-1981) (MARTINUS, 1990). Intencionalmente, Lauffer visitou e conversou com moradores das áreas mais isoladas a fim de ampliar seu vocabulário com palavras e ditos populares. Sua poesia e prosa são ricas em folclore e ritmo da língua. A única dificuldade, contudo é que Lauffer não oferece significados para o vocabulário que usa, assim o leitor, muitas vezes, não tem certeza se entendeu o sentido de uma palavra não conhecida ou não. Por 
essa razão o uso ativo de palavras aprendidas através do estudo de Lauffer não foi feito (MARTINUS, 1990).

Durante o século XIX e a primeira parte do século XX, a grafia do papiamentu seguia princípios etimológicos, isto é, a grafia era feita de acordo com a origem da palavra. Assim, se uma palavra veio do espanhol, por exemplo, casa, grafava-se cas. Em 1915, segundo Pieters (1993), houve uma discussão pública em Amigoe di Curaçao quanto à escrita em papiamentu. De 1915 em diante, travou-se uma luta constante de quase 60 anos acerca da grafia. Em 1918, W.M. Hoyer chegou a escrever um livro intitulado Papiamentoe $i$ su manera di scirbié.

Em 1953, Antoine Maduro escreveu sobre o assunto no livro Ensayo pa yega na un ortografia uniforme pa nos papiamentu riba un base etimológiko ${ }^{25}$. De acordo com Martinus (1990), o ímpeto final para a padronização do papiamentu veio da área de Educação. Um importante fator para a padronização foi o pleito da UNESCO, lançado no começo da década de cinquenta, para que o ensino nas escolas fosse feito em língua materna, o que trouxe um apoio importante às línguas crioulas e outras línguas minoritárias por todo o mundo. Além disso, segundo Pieters (1993), houve estudos e relatórios sobre educação nas próprias Antilhas Holandesas que apontavam para uma situação linguística não muito comum nas instituições de ensino devido à pouca produção na educação.

Assim, diante da necessidade de uma grafia padrão, em 1961, a comissão Fo 'i hopi un so, sob a presidência de Luis Daal, entregou o seu relatório final do estudo de uma grafia para o papiamentu ao Governo Central (PIETERS, 1993: 9). Em 1963, Raul Römer, um linguista, recebeu a tarefa do Governo de desenvolver uma grafia uniforme para as Antilhas Holandesas. Após um estudo intensivo, ele formulou suas ideias em sua obra

${ }^{25}$ Ensaio para se chegar em uma ortografia uniforme para nosso papiamentu segundo uma base etimológica. 
chamada: Ontwerp voor een Spelling voor het Papiamento "Projeto para uma ortografia do papiamentu". Römer, segundo Pieters (1993), tomou como base uma análise fonológica do papiamentu.

Römer possuía grande prestígio nos ciclos acadêmicos de Amsterdam, mas, diferente da maioria dos antilhanos, ele era defensor da Teoria do afro-português. Sua convicção provavelmente estava ligada ao fato de que, na década de 50, ele tinha descoberto que o papiamentu era uma língua tonal. Os exemplos existentes no papiamentu acerca da diferenciação do tom são controversos e não comprovam que o papiamentu seria de fato língua tonal, tais como: papa "mingau", que possui um padrão acentual paroxítono, tom alto-baixo e papa "pai", que contém um padrão acentual oxítono, tom baixo-alto (exemplos retirados de Kouwenberg \& Murray (1994: 12). Pode-se dizer que essa diferença de significado não ocorre devido ao tom, mas sim devido ao acento.

Influenciado por sua visão particular acerca do papiamentu e também pelas grafias fonológicas que estavam sendo concebidas por outras línguas crioulas no momento, tais como o sranan no Suriname e o crioulo haitiano, Römer cometeu uma falha. O estudioso ignorou o fato de que o papiamentu era uma língua que já tinha sido grafada por pelo menos cem anos com uma grafia que, embora inconsistente, estava funcionando (MARTINUS, 1990: 142).

Apesar do radicalismo do seu ponto de vista, a grafia de Römer tinha a vantagem de facilitar a alfabetização nas escolas, uma vez que a meta de comissionar a grafia era a introdução do papiamentu nas escolas nos primeiros anos. Em 1969, Raul Römer entregou o ensaio para o Governo Central. Tal grafia foi bem recebida em Curaçao. Essa receptividade não ocorreu em Aruba, em que a grafia proposta foi considerada um ataque à cultura e tradição de Aruba (MARTINUS, 1990).

Posteriormente, o Governo decidiu fazer um estudo sobre a proposta de Römer e, em 
meados de 1970, instalou uma comissão conhecida como Komishon Maduro "Comissão Maduro", sob a presidência de Antoine Maduro, para modificar a grafia de Römer. Em setembro de 1970, a comissão entregou suas recomendações para o Ministério da Educação. Embora houvesse uma boa recepção das modificações na grafia pelas autoridades de Curaçao, Aruba não se mostrou favorável à proposta. Assim, o Governo Central permitiu que a decisão final fosse de cada ilha, que poderia ter sua própria grafia.

Em 1975, o Governo de Curaçao reuniu uma comissão de consultoria para analisar o trabalho feito pela Comissão Maduro. Essa nova comissão, sob a presidência de Silvio Jonis, entregou suas modificações da grafia Römer-Maduro para o representante de Educação de Curaçao em junho de 1975 (PIETERS, 1993). Finalmente, no ano de 1976, o governo de Curaçao aceitou a recomendação e adaptações que resultaram da grafia Römer-MaduroJonis. Nesse mesmo ano, o Conselho da ilha de Curaçao conseguiu permissão do governo federal para experimentar a grafia modificada de Römer com o objetivo de introduzir o papiamentu nas escolas. Aruba ilegalmente proclamou a sua própria grafia com base na etimologia. As diferenças entre Aruba e Curaçao estavam sendo debatidas acerca da grafia até janeiro de 1986, quando Aruba obteve o direito de secessão e se tornou um país no reino dos Países Baixos (MARTINUS, 1990: 143).

E, em 1983, de acordo com essa grafia, foi publicado o livro Ortografia di papiamentu. Em 1986, o governo de Curaçao instalou uma outra comissão para continuar a observar a grafia vigente. De acordo com Pieters (1993), as discussões acerca da grafia não cessaram.

Em dezembro de 2008, confirmou-se a grafia oficial do papiamentu, falado em Curaçao, sob um decreto governamental. Como a grafia atual do papiamentu é de motivação fonológica, há uma tentativa de se relacionar tanto quanto o possível um grafema a um som. Há algumas combinações de grafemas que representam um som, por exemplo, o $<\mathbf{c h}>$ representa o som de $\left[\int\right]$. O alfabeto do papiamentu consiste nos seguintes grafemas: $<$ a, 
$\mathbf{b}, \mathbf{c}, \mathbf{d}, \mathbf{e}, \mathbf{f}, \mathbf{g}, \mathbf{h}, \mathbf{i}, \mathbf{j}, \mathbf{k}, \mathbf{l}, \mathbf{m}, \mathbf{n}, \mathbf{o}, \mathbf{p}, \mathbf{q}, \mathbf{r}, \mathrm{s}, \mathrm{t}, \mathrm{u}, \mathrm{v}, \mathrm{w}, \mathrm{x}, \mathrm{y}, \mathrm{z}>$. Quanto às vogais e consoantes modificadas, têm-se: $<\grave{\mathbf{e}}, \grave{\mathbf{o}}, \mathbf{u}, \ddot{\mathbf{u}}, \tilde{\mathbf{n}}>$. Assim, o alfabeto é constituído por 31 grafemas, 9 vogais e 22 consoantes (FPI, 2009).

As nove vogais do papiamentu são: $(<\mathbf{a}>/ \mathbf{a} /$ bals "chiclete" $-<\mathbf{e}>/ \mathbf{e} /$ sker "quebra"- $<\mathbf{i}>/ \mathbf{i} /$ tin "tem"- $<\mathbf{o}>/ \mathbf{o} /$ bonchi "feijão"- $<\mathbf{u}>/ \mathbf{u} /$ muf "mover-se"-

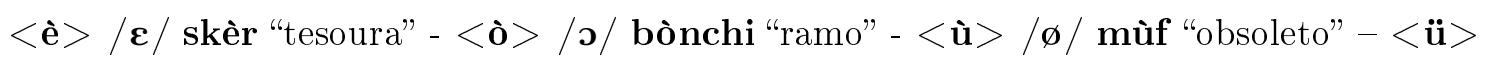
/y/ püs "roxo"). A vogal dobrada é usada em contextos específicos, pronunciando-a de forma separada: ko-operá "cooperar"; re-editá "reeditar"; o-ochi "gêmeo"; shi-ita "xiita". O schwa tem o som representado pelo grafema e e os exemplos são os seguintes: mangel "doce"; laken "lençol de cama".

Quanto às consoantes, o papiamentu possui 22 , sendo que as consoantes $<\mathbf{c}, \mathbf{j}, \mathbf{x}\rangle$ são usadas apenas na combinação com outras consoantes (como $\mathbf{c h}, \mathbf{d j}$ e zj). Segundo FPI (2009: 15), tais consoantes são usadas nos seguintes contextos:

(a) Na matemática, química etc;

(b) No começo de parágrafos de uma cláusula de artigos;

(c) Em nomes próprios (Cornelia' $\left.{ }^{26}\right)$;

(d) Em nomes geográficos adotados de outros idiomas que tiveram sua forma gráfica mantida (Connecticut);

(e) Palavras adotadas de outros idiomas e consideradas "estrangeiras" (centerfielder, x-ray).

Além disso, na grafia do papiamentu, nenhuma palavra termina com: $<\mathbf{b}-\mathbf{d}-\mathbf{h}-\mathbf{v}-\mathbf{w}-$ $\mathbf{y}-\mathbf{z}>$. Uma palavra pode terminar $\operatorname{com}<\mathbf{c h}>\mathrm{e}<\mathbf{s h}>$, como em: sèntwich "sanduíche"

${ }^{26}$ Apelidos carinhosos, contudo são adaptados para a grafia nativa como Koni para "Cornelia". (FPI, 2009). 
e kèsh "caixa". No papiamentu, não se escrevem, em geral, consoantes dobradas, contudo há exceções. Quando a forma de plural está em uma palavra que termina com grafema $<\mathbf{n}>$, o $<\mathbf{n}>$ é dobrado, por exemplo: sèn - sènnan "centavo - centavos"; ruman rumannan "irmão -irmãos". E, por fim, quando uma palavra tem o acréscimo do prefixo in e essa palavra começa com o grafema $<\mathbf{n}>$, assim tal letra dobra-se também: nesesario -innesesario "necessário -desnecessário" (PIETERS, 1993).

A consoante $<\mathbf{g}>$ constituiria uma das exceções à regra de grafia fonológica que possui a premissa segundo a qual cada grafema representa um som. De acordo com Pieters (1993), o grafema $<\mathbf{g}>$ representa dois sons: o sonoro (vozeado) e o surdo (desvozeado). Diante de $<\mathbf{a}, \mathbf{o}, \mathbf{u}, \mathbf{l}, \mathbf{r}>$, tem-se o $\mathbf{g}$ sonoro: gaba "gabar-se"; gol "gol"; guli "engulir"; glas "vidro"; grandi "grande".

Em contrapartida, diante de $<\mathbf{e}, \mathbf{i}, \grave{\mathbf{u}}>$, tem-se o g surdo: general "geral"; giro "giro"; ougùrk "picles". No final de palavra, pode haver um g surdo, como em: brùg "ponte". Para se ter um $\mathbf{g}$ sonoro diante de $u$ m $<\mathbf{e}>$ ou de $\mathbf{u m}<\mathbf{i}>$, deve haver o grafema $<\mathbf{u}>$ após $<\mathbf{g}>$ : guera "guerra"; sigui "seguir". O grafema $<\mathbf{u}>$, segundo Pieters (1993), nesse caso não tem som, o $<\mathbf{u}>$ é mudo e só cumpre a função de sinalizar a mudança de som do g-surdo para o g-sonoro. Se após o $<\mathbf{g}>$ estiver o grafema $<\mathbf{e}>$ seguido por $<\mathbf{l}>$ ou $<\mathbf{r}>$, o som será sonoro, como nas palavras angel "anjo" e sanger "sangue".

Para Joubert (1991:156), a busca pela padronização da grafia do papiamentu enfrenta problemas ainda hoje ao lidar com palavras provenientes de empréstimo. A comissão responsável pela padronização gráfica constantemente se vê em um dilema: ou escolhe uma única palavra emprestada entre um conjunto de palavras emprestadas ou aceita todas como palavras da língua. Caso a segunda opção seja escolhida, a palavra fonte do empréstimo é submetida às adaptações gráficas necessárias para que seja considerada por todos como um item lexical nativo. 


\subsection{Prefixos e Sufixos}

Segundo Goilo (1953), no papiamentu, é muito comum a derivação de palavras através do uso de afixos (ver exemplos). Embora Goilo defenda a existência de tais afixos, são elementos de difícil comprovação. No caso de palavras como mudanza "mudança", por exemplo, não é possível afirmar com certeza se anza é um afixo no papiamentu ou a palavra como um todo foi tomada de empréstimo seja do português ou espanhol. Desse modo, é possível que todos os vocábulos citados como exemplos da presença de afixos por Goilo sejam, na verdade, exemplos de vocábulos que chegaram ao papiamentu sob um formato e foram mantidos assim. Logo, tais "afixos" nada mais são do que partes "congeladas" ou cristalizadas dos itens lexicais emprestados. O autor cita exemplos tais como:

1. anza: muda (verbo) - mudanza "mudança'.

2. or, dor: skirbir (verbo) - skirbidor "escritor".

3. bel, ble: aborecé (verbo) - aborecibel ou aborecible "aborrecível".

4. ción: tenta (verbo) - tentación "tentação".

5. mentu: casa (verbo) - casamentu "casamento".

6. ida: bebe (verbo) - bebida "bebida".

7. ada: pica (verbo) - picada "picada".

8. oso: odia (verbo) - odioso "odioso".

9. ente: pretendé (verbo) - pretendiente "pretendente". (GOILO, 1974: 40)

Os sufixos variam semanticamente, como se pode notar através dos exemplos.

- ada pode denotar (GOILO, 1974: 40) 
1. Capacidade: tonelada "tonelada";

2. Duração: temporada "temporada;

3. Golpe: puñalada "punhalada";

4. Qualidade abstrata: soquetada "estupidez";

5. Instituição: embahada "embaixada".

- al denota geralmente qualidade: mortal "mortal"; carnal "carnal".

- anu pode denotar pertencimento, como em: coreanu "coreano"; arubianu "árabe".

- ante geralmente se refere à ocupação, como em: comediante "comediante"; estudiante "estudante".

- ario pode se referir à profissão, como em: empresario "empresário".

(-) ero, era se refere à profissão, como em: costurera "costureira".

(-) eño, anu, es, ense, ayo denotam nacionalidade: porto-riqueño "porto-riquenho", curazoleño "curaçolenho", arubiano "árabe", hulandés "holandês", chinés "chinês", costaricense "costa riquense".

Uma questão no estudo de Goilo (1974) é o fato de ele fundamentar toda sua análise em uma gramática tradicional espanhola que, por ser prescritiva, não poderia ser o seu único embasamento teórico. Além disso, o autor faz afirmações acerca dos morfemas sem demonstrar qualquer base empírica. Apesar das falhas apontadas, o presente estudo analisa o trabalho de Goilo, por ser um dos poucos a lidar com o problema da morfologia no papiamentu, sobretudo no que tange à existência ou não de afixos como -mentu e -do na língua. 
Em relação aos sufixos, há uma grande soma de palavras que terminam com -mentu, o que revela sua alta produtividade (MULLER, 2007: 55-57). De acordo com Muller (2007), geralmente tais palavras são fruto da combinação de verbo somado ao sufixo supracitado que, em conjunto, forma um nome. Na maioria das vezes, a combinação de uma palavra verbal e esse sufixo pode expressar atividade física, como em: balia - baliamentu "dançar - dança"; hari - harimentu "rir - riso"; kore - korementu "correr - corrida". Tal combinação, contudo pode indicar também uma atividade relacionada a um processo mental: pensa - pensamentu "pensar - pensamento"; skucha - skuchamentu "ouvir audição". Além de atividade física e mental, palavras com -mentu podem indicar um processo: kima - kimamentu "queimar - queima"; lèk -lekmentu "escapar - escapamento"; sufri - sufrimentu "sofrer - sofrimento".

Alguns verbos não aceitam a derivação através do sufixo -mentu, tais como: eksistí, konmové, sosodé "existir", "mover", "acontecer", respectivamente. Por outro lado, há verbos que aceitam não só o -mentu, como também -shon. A maioria desses verbos possui duas sílabas: splika, splikamentu, splikashon "explicar" e "explicação" (MULLER, 2007). Segundo Muller (2007: 56), “[...] várias palavras que terminam com -shon são tomadas diretamente do espanhol, naturalmente com a combinação necessária para passar pela estrutura do papiamentu."

Segundo Goilo (1974: 45-46), quanto aos prefixos, devido à forte presença ibérica no papiamentu, é possível encontrar muitos de origem latina (antayera "anteontem"; circunstancia "circunstância"). Contudo não há razão para considerar que tais morfemas existam no papiamentu como prefixos, pois eles se encontram cristalizados nos vocábulos. Em outras palavras, tais prefixos são encontrados apenas nos vocábulos tomados de empréstimo do português e do espanhol, não é possível encontrá-los em vocábulos nativos ou em outros itens lexicais que não tenham relação com palavras de origem ibérica. 


\subsection{Estudos prévios}

Entre as línguas crioulas, o papiamentu dificilmente pode ser visto como uma língua negligenciada, uma vez que tem despertado o interesse de estudiosos. Durante o último século até o momento, tem-se um número significativo de artigos, teses e dissertações. Alguns desses trabalhos que contribuíram de forma significativa para o estudo do papiamentu e, que são relevantes para o presente estudo, serão revistos e discutidos na subseção seguinte. Importante salientar que serão contemplados na discussão apenas os estudos que foram mais relevantes para a pesquisa.

\subsubsection{Papiamentu: estudos linguísticos prévios}

Rodolfo Lenz (1928), a bordo de um navio cruzeiro que o levaria à Europa, trabalhando apenas com um informante, foi um dos primeiros a escrever sobre o papiamentu. Ainda que Maduro (1967) aponte inúmeras falhas no trabalho de Lenz, ele também reconhece a importância do estudo e seu empenho ao produzir uma análise com poucos recursos. Uma das principais contribuições desse estudioso é a sua tese de que o papiamentu se originou de um pidgin afro-português falado no Oeste da África, posteriormente, segundo Lenz (1928), ele adquiriu novo vocabulário do espanhol e holandês em seu novo cenário e, como resultado, teria perdido a maioria dos seus itens lexicais originais africanos.

Em 1951, Charles Cleland Harris escreveu sua tese de doutorado sobre a fonologia do papiamentu. Seu estudo se baseou em dados produzidos por um informante de vinte e três anos, pertencente à alta classe, nativo de Curaçao, que estava vivendo nos Estados Unidos por dois anos no momento em que o material foi gravado. Seus dados consistiam de duas mil declarações curtas, setecentas sentenças e trinta minutos de conversa livre entre dois informantes anônimos. Seu estudo faz uma análise sincrônica da fonologia sob 
a perspectiva estruturalista predominante no momento do seu trabalho. Sua pesquisa foi um dos estudos pioneiros no que diz respeito à fonologia do papiamentu.

Em seu artigo Observaciones sobre el papiamentu, Navarro (1951) afirma que o papiamentu seria, inicialmente, um dialeto afro-português que se desenvolveu em Curaçao desde o século XVII sob o domínio holandês. O estudioso não considerava o papiamentu uma língua crioula de base espanhola. Em seu trabalho, com base no estudo de Lenz (1928), Navarro reúne dados e evidências que poderiam dar suporte a sua afirmação: (1) palavras do papiamentu que poderiam ser de origem portuguesa; (2) nasalização de vogais no papiamentu; (3) as similaridades entre o português e o papiamentu como opostas ao espanhol, haja vista que tanto o português quanto o papiamentu têm vogais altas (i, u) em muitas palavras em que o espanhol tem vogais médias (e, o); (4) em palavras com suposta origem espanhola, Navarro afirma que tais palavras seriam de origem portuguesa e que, após sofrerem mudanças fonológicas no papiamentu, passaram a se assemelhar mais ao espanhol. O estudo de Navarro é frequentemente citado como evidência para (i) origem do papiamentu a partir de um pidgin afro-português; (ii) prova de que o papiamentu tem sido hispanizado. Uma falha na argumentação de Navarro é o fato de ele não apresentar fatos para nenhuma das duas evidências.

No que tange ao estudo de empréstimo, Richard Wood fez significativas contribuições sobretudo no que diz respeito às influências do holandês para essa língua (1970, 1972a), embora Wood também discuta sobre a origem (1972b), a hispanicização do papiamentu e os aspectos linguísticos da educação em Curaçao. O estudo sobre as contribuições do holandês no papiamentu $(1970,1972 a)$ representa uma das partes mais importantes do seu trabalho, haja vista que, nesses trabalhos, ele oferece etimologias e notas extensivas para 558 itens lexicais de origem holandesa. Wood afirma que muitos termos técnicos holandeses 
estariam entrando no papiamentu principalmente nos campos lexicais que dizem respeito à política e à administração.

Antoine Maduro publicou inúmeros trabalhos sobre o papiamentu, tais como estudos etimológicos $(1953,1966)$; uma coleção de excertos reimpressos de livros, artigos e cartas relacionados à origem do papiamentu, com comentários em papiamentu (1965); observações em relação ao trabalho de Lenz (MADURO, 1967); uma crítica do papiamentu usado pelos anunciantes de rádio e televisão e, especialmente, em jornais (1971); e outras inúmeras publicações. Embora não seja linguista, Maduro buscou fazer uma pesquisa sobre possíveis fontes para o vocabulário do papiamentu. Em seu trabalho (1953), Maduro lista 2.500 itens lexicais no papiamentu acompanhados da etimologia. Em 1966, acrescenta mais entradas lexicais e uma discussão mais detalhada de cada item.

A grande maioria de suas publicações começa com Maduro apresentando uma tentativa de refutar a hipótese afro-portuguesa, defendida por Lenz (1928), Navarro (1951) e outros. Ele indica inúmeros erros nos dados desses autores com respeito às etimologias portuguesas que eles atribuem e mostra também que a maioria dos itens lexicais que é usada para provar a origem do papiamentu a partir do português pode ser facilmente relacionada a uma origem catalã ou galega ou ter se originado em algum dialeto espanhol peninsular. E quanto aos outros itens supostamente de origem portuguesa, para Maduro, esses seriam devido à presença dos judeus luso-falantes que começaram a chegar a Curaçao em meados do século XVII.

De acordo com Maduro, formas do galego, catalão e de vários dialetos do espanhol peninsular foram emprestadas sem qualquer modificação para o papiamentu. De acordo com o estudioso, o papiamentu teria feito tais empréstimos linguísticos através de marinheiros, comerciantes e negociantes que falavam essas línguas e dialetos em vez de um castelhano padrão, haja vista que, segundo Maduro, todas essas línguas e dialetos eram falados em 
regiões com portos marinhos. Percebe-se que ainda faltava uma análise linguística adequada dos dados que Maduro oferece como suporte de suas afirmações, análise essa que tem sido feita por Freitas (em preparação) com base na lista Maduro.

Estudos posteriores, tais como o de Wood $(1970,1972)$ e Andersen (1974), são sistemáticos em suas descobertas. Quanto à nativização e adaptação de empréstimos, Wood (1972), ao fazer uma análise sobre a presença do inglês no léxico do papiamentu, constata que os empréstimos de palavras do inglês ocupam a terceira posição de importância no léxico (1\%) depois do ibérico (espanhol, português), que possui $90 \%$ e do holandês $(+/-$ 9\%). Ele também observa que empréstimos africanos são menos significativos do que em outros crioulos do Atlântico, tais como os crioulos sranan, haitiano ou crioulo jamaicano. Exemplos de palavras emprestadas adaptadas para o sistema fonológico do papiamentu são os seguintes: blufein "relativo a varizes" do inglês blue vein; scubadaifer $_{513}$ "mergulho com botija" do inglês scubadiver. Wood também faz menção às palavras do inglês tais como: shap "taverna; bar" e skars "escasso", que aparecem em derivações com sufixos em espanhol.

Andersen (1974) analisa o léxico do papiamentu do ponto de vista da sociolinguística, estabelecendo regras de nativização do espanhol, holandês, inglês e palavras africanas e outras línguas que contribuíram para o léxico do papiamentu. De acordo com Andersen, a adaptação fonológica de empréstimos no curso da história do papiamentu e a variação fonológica no léxico do presente dia submetem-se a algumas restrições. A fim de distinguir entre um item lexical nativo e um emprestado, ele estabeleceu diversos critérios fonológicos que identificariam um item lexical nativo. Eles são os seguintes:

(a) Restrição de mesma altura, por exemplo: o do espanhol /su'dor/ torna-se /so'do/ "suor"; 
(b) Formato canônico de CV como o tipo de sílaba mais nativo: por exemplo, o do espanhol apos.tar torna-se pus.ta "apostar";

(c) A predominância de palavras dissilábicas: o do espanhol se.ma.na se adapta como si.man²7; o do espanhol a.tre.bi.do se adapta para tri.bí "atrevido";

(d) A predominância do acento penúltimo, acompanhado por um certo padrão de comprimento tonal e queda de tom na sílaba da penúltima vogal; tom crescente na sílaba final: o do espanhol komprár torna-se no papiamentu kúmpra "comprar";

(e) Eliminação de encontros consonantais não permitidos: do espanhol guapo é adaptado para wapu'28 "bonito" no papiamentu;

As restrições de (a) até (e) também funcionam como algum tipo de filtro que, ao lado de regras de conversão, se aplicam para absorver palavras de empréstimo do espanhol, holandês e outras palavras de empréstimo em sistema fonológico nativo. Andersen dá muitos exemplos de variação fonológica no papiamentu do presente dia que refletem essas restrições. As mais frequentes são as seguintes:

(a) A tendência à assimilação como em: limonada > lumunada "limonada";

(b) A tendência para produzir padrões $C V$ por um apagamento de consoante, inserção de vogal e elisão de sequências VV em fim de palavra, como em: mester > mesté "dever"; sanger > sangr > sangu "sangue"; for di > fo'i "de; desde";

(c) A tendência a reduzir palavras trissilábicas em dissilábicas é vista como resultado de uma regra geral que favorece palavras de duas sílabas, como em: $\operatorname{siman}<\operatorname{semana;}$

${ }^{27}$ Nesse exemplo, nota-se algo que pode ser um equívoco de Andersen, pois o que acontece é o apagamento da vogal átona final, não necessariamente o caso de haver ou não duas sílabas em si.man < se.ma.na "semana".

${ }^{28}$ Segundo Lipski (2007), no espanhol do Caribe, é possível encontrar o < gu > pronunciado como [w], o que contraria Andersen (1974). 
(d) O apagamento do pós-consonantal ou pré-consonantal -r, e o apagamento do glide, como em: skirbi > skibi "escrever"; piedra > pieda "pedra"; despues > despué $>$ despé "depois"; aunke $>$ ounke $>$ anke $>$ ònke "se". (ANDERSEN, 1974: $82-26)$

Embora Andersen afirme que os seus critérios se aplicam a todas as palavras nativizadas, tais critérios não parecem se aplicar tão bem assim. Um exemplo pode ser visto em palavras como kiper $_{471}$ "goleiro" em papiamentu que não sofreu o processo de apagamento do segmento final -r mesmo havendo a tendência de se produzir o padrão CVCV.

Além disso, outra falha no texto de Andersen é o fato de que ele não parece considerar que as palavras de L2 entraram em várias fases do papiamentu e, por essa mesma razão, tais palavras estavam sujeitas a conjuntos de regras de nativização específicas de cada tempo. Assim, é preciso ter cuidado ao fazer generalizações de regras que abranjam um período de época muito grande como um século por exemplo.

Ainda no tocante ao empréstimo, Philippe Maurer, em El papiamento de Curazao: um idioma verdaderamente americaño (1991), apresenta exemplos que comprovam a influência não-ibérica não só no léxico, mas também na gramática do papiamentu. Para o autor, tais exemplos mostram como a língua crioula tem alcançado autonomia diante do espanhol, língua que outrora cedeu grande parte do seu léxico segundo o autor.

Outro estudo representativo sobre o papiamentu, sobretudo em relação às hipóteses de sua origem, encontra-se no livro The kiss of slave de Martinus (1996), que teve como objetivo precípuo apresentar novas evidências comprovadoras da teoria crioula de um protoafro-português. Ademais, o estudo de Martinus (1996) busca demonstrar que o papiamentu iniciou sua formação nas antigas Antilhas Holandesas por volta de 1640 como uma "mistura" de diversos dialetos do afro-português. Anteriormente, tal "mistura" foi levada da costa oeste da África através do comércio escravo para o mundo colonial. Com base em 
uma comparação fonológica e histórica entre dados do papiamentu, crioulos de Cabo Verde e o crioulo da Guiné-Bissau, o estudioso demonstra mais de oitenta ligações entre essas línguas.

Na primeira parte do livro, Martinus discute as principais hipóteses que dizem respeito à origem do papiamentu. Na segunda parte da obra, são abordadas as ligações linguísticas, históricas, demográficas entre o papiamentu e os crioulos de base portuguesa. Já a terceira e última parte busca descrever os crioulos do Oeste africano envolvidos na formação do Guene de Curaçao. Por meio de exemplos, Martinus faz comparações extensivas de mudanças de som dos crioulos do oeste africano e caribenho a fim de estabelecer diferentes graus de conexão.

Outro estudo relacionado à investigação da possível origem do papiamentu é o de Bart Jacobs (2009) em um artigo chamado The Upper Guinea origins of papiamentu: linguistic and historical evidence. Esse artigo enfoca as origens afro-portuguesas do papiamentu. Nesse trabalho, Jacobs propõe a hipótese de que os crioulos de Cabo Verde, Guiné-Bissau, Casamansa e o papiamentu possuem uma origem comum. Para comprovar essa hipósese, Jacobs compara palavras de cinco categorias gramaticais pertencentes aos crioulos supracitados. Nessa comparação, o autor demonstra que a maioria das palavras funcionais do papiamentu se assemelham às palavras dos crioulos de base portuguesa da Alta Guiné tanto na forma, mas também quanto à semântica e uso sintático. Assim, o estudo de Jacobs contribui para a discussão acerca da origem dessa língua crioula. Questão essa que ainda é um ponto de grande debate.

É importante também mencionar que muitos estudos foram realizados a respeito da grafia do papiamentu. Uma dessas análises pode ser vista no artigo intulado La estandarización de una lengua criolla: el papiamento, de Sidney Joubert (1991). Neste artigo, 
Joubert trata da história da padronização do papiamentu, do seu estado atual e dos resultados alcançados nos últimos anos. A discussão empreendida por Joubert aborda questões bastante pertinentes quanto à padronização de uma língua, como, por exemplo, os principais critérios envolvidos no processo, que são a frequência, a adaptabilidade, a produtividade e a transparência de uma palavra a ser padronizada graficamente. Todos os critérios são discutidos no texto, tendo em vista as palavras do papiamentu. Além disso, Joubert elenca e debate, nesse trabalho, os problemas mais comuns encontrados pela comissão de estandardização.

O estudo desenvolvido por Kouwenberg \& Murray no livro Papiamentu (1994) é leitura obrigatória para aqueles que têm interesse em conhecer a fonologia, morfologia e sintaxe da referida língua. Segundo os autores, parte das informações dispostas no livro esteve baseada nas intuições oferecidas pelos falantes nativos do papiamentu de Curaçao e Aruba. O estudo se divide basicamente em três partes. A primeira, dedicada à fonologia, trata dos sistemas vocálico e consonantal do papiamentu; da estrutura silábica e há também uma seção extensa sobre tom e acento. A segunda parte do livro concentra-se na morfologia, abordando questões como a flexão; a reduplicação; as formações de nomes através do uso dos sufixos -mentu e -dó; os processos de prefixação e compostos frasais. E, por fim, tem-se o capítulo dedicado à sintaxe, em que podemos ver como se dá a formação de questionamento, foco, processos de transformação de uma frase ativa em passiva, reflexivos, as construções de cópula, entre outros processos comuns no âmbito sintático.

Em Linguistic Studies on Papiamentu (FARACLAS, SEVERING, WEIJER \& ECHTELD, 2008), é possível conhecer resultados de estudos de diversas áreas acerca do papiamentu. Os treze artigos encontrados nessa compilação são versões atualizadas de ensaios apresentados em uma conferência internacional de línguas crioulas, realizada em Curaçao 
em 2004. Neste livro, encontram-se estudos pontuais acerca de temáticas que, mesmo variadas, abordam questões de grande interesse do meio acadêmico, tais como o uso, atitude e identidade da língua entre falantes do papiamentu, escrito por Hélène Garret; a presença do português em Curaçao por Joubert e Matthias Perl e artigos como o de Rivera-Castillo e Lucy Pickering que falam sobre os correlatos fonéticos de tom e acento no papiamentu de Curaçao.

Após esse breve panorama dos estudos linguísticos realizados sobre papiamentu, esperase que a presente pesquisa também possa contribuir para a ampliação dos conhecimentos acerca da referida língua. Antes que a análise de dados comece a ser feita, faz-se necessário que, previamente, sejam discutidas as principais teorias a respeito de empréstimo linguístico e sua adaptação fonológica e morfológica, o que será realizado no próximo capítulo. 


\section{Capítulo 3}

\section{Adaptação de Empréstimos}

Neste capítulo, serão discutidas as principais correntes linguísticas que tem como objeto de estudo o empréstimo e sua adaptação na língua recipiente. Na subseção 3.1, serão levantadas questões a respeito da importância desses estudos e as razões pelas quais pesquisas nessa área têm aumentado. Na subseção 3.1.1, os estudos de empréstimo baseados na percepção serão discutidos. Em seguida, na subseção 3.1.2, examinar-se-ão as pesquisas que estudaram o empréstimo sob a ótica da produção. Posteriormente, serão demonstradas as análises que buscam unir a produção e a percepção. Na subseção 3.1.3, serão apresentados os estudos baseados na percepção e na produção, contudo, em níveis distintos. Na subseção 3.1.4, demonstrar-se-á outra possibilidade de análise linguística que são os estudos sob a perspectiva da similaridade perceptual.

No que diz respeito aos estudos da fonologia de empréstimo, a pronúncia de palavras emprestadas tende a ser submetida a adaptações sistemáticas ou nativização. Neste estudo, o termo empréstimo, como definido em (1), é aqui empregado como item(ns) lexical (is) introduzido(s) na língua alvo (L1) por falantes nativos que têm acesso à língua emprestadora (L2). A nativização ou a adaptação dos empréstimos de L2 em L1 são regidas por padrões fonológicos de L1, padrões impostos pelos falantes de L1 (PARADIS \& LABEL, 1994). 
(1) Empréstimo: uma palavra simples ou composta, ou uma sentença oriunda de L2, incorporada ao discurso de L1 (PARADIS \& LABEL, 1994).

Em relação aos empréstimos, Paradis (1996) afirma que os falantes de L1 tendem a interpretar a estrutura de L2 conforme a estrutura de L1. Além disso, os falantes de L1 frequentemente descartam, das palavras incorporadas via empréstimo, informações, contidas em L2, percebidas como redundantes do ponto de vista de L1. No percurso de L2 (nesse caso, espanhol, português, holandês e inglês) até L1 (papiamentu) ocorre uma série de modificações, uma vez que a estrutura linguística dessas línguas é diferente.

De acordo com Strange (1995) e Holt (2008), pode-se caracterizar a fala humana por meio da falta de constância, isto é, nem sempre há uma correspondência direta de um para um entre fonemas e categorias fonéticas ${ }^{29}$. Ainda que a inconstância pareça conferir dificuldades no estabelecimento de categorias fonéticas, os humanos apresentam uma grande capacidade de discriminar sons de fala de forma categórica, como, por exemplo, discriminar as categorias fonéticas entre as oclusivas vozeadas /b/, /d/ ou /g/ (Cf. REIS, 2010). Tal capacidade pode também ser observada nas adaptações de empréstimo. A forma emprestada resultante, com frequência, não só se conforma à fonologia nativa de L1, quanto carrega uma similaridade com a forma original na medida do possível. A adaptação de empréstimo pode envolver estruturas fonológicas em vários níveis, variando de traços segmentais a regras fonotáticas e padrões prosódicos (Cf. WEINREICH, 1968; HOCK \& JOSEPH, 1996; CAMPBELL, 1998).

Um exemplo de adaptação pode ser visto na palavra provinda do inglês blog ['blag], que, ao ser tomada de empréstimo para o português brasileiro (PB), foi nativizada como ['blogi] blogue (PRADO \& MASSINI-CAGLIARI, 2011:27). Observa-se que houve adição

${ }^{29}$ Lotto e Sullivan (2007 apud REIS, 2010) descrevem a categorização fonética como o processo pelo qual ouvintes interpretam e avaliam múltiplas pistas presentes nos sons da fala, processo que é finalizado com a determinação de um segmento fonético ao som ouvido. 
de uma vogal paragógica para que fosse atendida a restrição no PB que proíbe consoantes oclusivas na coda silábica.

Ao analisar casos como o da palavra blogue, adaptada para o português, constata-se que a nativização de empréstimos em uma língua não é feita de forma aleatória ou imotivada, mas guiada por restrições ${ }^{30}$ fonológicas presentes na língua nativa. Diante de um fenômeno com fatores múltiplos, o objetivo primordial da pesquisa consiste em investigar fatores perceptuais e fonológicos que regulariam a variabilidade da adaptação de empréstimo no papiamentu moderno.

\subsection{Empréstimo: correntes teóricas}

Quanto à importância do estudo de empréstimos, Calabrese \& Wetzels (2009) afirmam que a análise de empréstimos em uma língua nos oferece uma janela direta tanto para o estudo de como os signos acústicos são categorizados em termos de traços distintivos relevantes para o sistema fonológico de L1, como para o estudo da fonologia sincrônica de L1 ao observar seu processo fonológico em ação. Nas duas últimas décadas, segundo Kenstowicz (2004), observou-se que o estudo de empréstimos linguísticos evoluiu de uma curiosidade mínima para um fenômeno merecedor de estudos sérios e contínuos. Para o pesquisador, a motivação mais significativa tem sido, sem dúvida, a mudança conceitual no campo de regras para um modelo de reparos e restrições de mudança fonológica.

\footnotetext{
${ }^{30}$ Segundo a perspectiva da OT, toda gramática de uma língua é um sistema de forças conflitantes. Essas forças são incorporadas por restrições, cada uma delas requisita algum aspecto das formas de outputs gramaticais. Restrições são tipicamente conflitantes, no sentido de que satisfazer uma restrição implica a violação de outra. Diante do fato de que nenhuma forma pode satisfazer todas as restrições simultaneamente, deve haver um mecanismo que seleciona formas que incorrem menos violações de restrição de outras que aplicam violações mais sérias. Esse mecanismo seletivo envolve ranking hierárquico de restrições, tais como aquelas restrições posicionadas mais altas no ranking têm prioridade em relação aos posicionados mais abaixo. Enquanto restrições são universais, os rankings não são: as diferenças no ranking são a fonte da variação entre línguas (KAGER, 1999: 4).
} 
Além disso, a fonologia de empréstimos linguísticos toma o status de algo semelhante a uma "experiência" ao permitir investigar a competência fonológica (KENSTOWICZ, 2004). Por essa razão, para Kenstowicz, diversas questões metodológicas têm emergido nessa tentativa, tais como a distinção entre empréstimos integrados e "on-line", o papel da grafia, bem como a natureza frequentemente variável dos dados que necessitam de generalizações e tendências estatísticas em vez de regras categóricas. E, por fim, segundo o autor, há, em um número significativo, casos de adaptações que convergem em estratégias de reparo que carecem de um precedente no sistema nativo e, às vezes, podem mesmo contradizer reparos de L1, criando enigmas para os estudiosos. Um exemplo desse enigma pode ser visto na língua hmong, que possui um formato silábico restrito $\mathrm{CV}(\mathrm{V})$ e não apresenta alternâncias que envolvam apagamento ou epêntese em palavras nativas (GOLSTON \& YANG, 2001). Tal característica muda no tocante aos empréstimos. Em palavras emprestadas, ocorre com frequência o apagamento segmental. Por exemplo, a palavra [pe.si] é uma adaptação da palavra pepsi do inglês. De acordo com Peperkamp \& Dupoux (2001), se se pensar sob uma abordagem baseada em regras, o apagamento da consoante na coda pode ser explicado por uma regra que estaria ausente no sistema fonológico da língua nativa. Por outro lado, se pensarmos sob a perspectiva desenvolvida por Prince \& Smolensky (1993) na Teoria da Otimalidade, podemos supor que, embora as restrições sejam universais e as adaptações estejam ausentes na fonologia nativa, as restrições fazem com que as últimas estejam presentes.

De acordo com Kenstowicz (2001), há ao menos três fatores que motivam o estudo da fonologia de empréstimo de palavras. Primeiro, empréstimos de palavras têm sido usados para testar a produtividade de regras e restrições fonológicas. Em alguns casos, empréstimos oferecem uma evidência crucial para definir a análise de dados, que de outro modo permaneceria inconclusiva do ponto de vista do sistema nativo (L1) (SHINOHARA, 1997). 
Segundo, quando empréstimos acontecem em uma escala massiva, a língua doadora pode partilhar aspectos de sua fonologia com o sistema nativo que necessitam de setores distintos do léxico com suas próprias mini-fonologias. Há um debate sobre até que ponto isso desafia a noção de uma única gramática (WEINREICH, 1953; ITÔ \& MESTER, 1995) e representa a intrusão de acidentes da história em sistema uniforme e, do contrário, "limpo". Finalmente e mais recentemente, padrões de adaptação têm sido descobertos para o que o sistema nativo não oferece orientação ou, mesmo, se contradiz profundamente, colocando um questionamento acerca da capacidade de aprendizado semelhante aos processos naturais causados pela aquisição de língua primária de Stampe (1972). Tal questionamento sobre o aprendizado dos mecanismos de empréstimos ocorre, pois se discute como as crianças podem distinguir palavras emprestadas das palavras nativas e, em seguida, aprender as transformações aplicadas a tais palavras.

Embora não haja muitos pontos de acordo sobre determinadas questões acerca da adaptação de empréstimo, as razões pelas quais o falante faz tal empréstimo é bastante consensual no âmbito da linguística:

Speakers borrow words from other languages to fill gaps in their own lexical inventory. The reasons for such lexical gaps vary greatly: cultural innovation may introduce objects or actions that do not have a name in the native language; native words may be perceived as non-prestigious; names of foreign cities, institutions, and political figures which were once unknown may have entered the public eye; new words may be introduced for play, etc. (CALABRESE \& WETZELS, 2009: 1) ${ }^{31}$.

${ }^{31}$ Falantes tomam emprestado palavras de outras línguas para preencher lacunas em seu próprio inventário lexical. As razões para tais lacunas lexicais variam grandemente: inovação cultural pode introduzir objetos e ações que não tenham um nome na língua nativa; palavras nativas podem ser percebidas como sem prestígio; nomes de cidades, instituições e figuras políticas estrangeiras que 
Para os referidos estudiosos, os empréstimos de palavras podem acontecer em dois possíveis e diferentes cenários. No primeiro, o empréstimo pode ser implementado por um falante bilíngue que preenche uma lacuna em uma das línguas que ele conhece, L1, a língua recipiente, ao tomar uma palavra de outra língua que ele conhece, L2, a língua doadora. Nesse caso, a suposição comum é que o falante recupera a representação subjacente da palavra emprestada do seu dicionário mental (o armazenamento de memória de longo prazo para itens lexicais) para L2 e gera sua representação superficial enquanto falante de L1. Se a representação superficial da palavra é gerada ao usar o sistema fonológico ou, mais geralmente, o sistema gramatical de L1, a palavra sofre adaptações e ajustes e é nativizada de acordo com a gramática de L1. Essa situação é chamada pelos autores de nativização através da produção (CALABRESE \& WETZELS, 2009).

Em outro cenário, o empréstimo é implementado por um falante que preenche uma lacuna em sua língua ao tomar uma palavra de outra língua que ele conhece parcamente ou de maneira nenhuma. Nesse caso, ele precisa aprender a palavra relevante. Uma vez aprendida a palavra, seja usada publicamente ou mesmo silenciosamente apenas pelo falante, tal vocábulo é um empréstimo. Considerando que o indivíduo não fala a segunda língua bem, a palavra apresentará ajustes e adaptações. Presume-se que essas modificações já ocorrem durante a aprendizagem e percepção. Esse caso é chamado de nativização através da percepção (CALABRESE \& WETZELS, 2009).

Apesar de ambos os modelos parecerem, no primeiro momento, inconciliáveis, para Calabrese \& Wetzels (2009), a percepção e produção não podem ser separadas no estudo de nativização de empréstimos, mas, em vez disso, devem ser vistas em sua interação cooperativa:

foram outrora desconhecidos podem ter se tornado de domínio público; novas palavras podem ter sido introduzidas por divertimento, etc. (Tradução nossa) 
In this nativization scheme, a bilingual borrower first produces the word in L2 and then uses that surface representation as input to the nativization process, which is phonological. If this is correct, the perceptual stance and phonological stance models no longer need be contrasted, and could be largely unified: the input to nativization is always phonetic, the word as it is "heard". The treatment, on the other hand, is always phonological and it can occur either during perception or during production ${ }^{32}$ (CALABRESE \& WETZELS, 2009: 10).

Conclui-se que a questão central na fonologia de empréstimo é investigar que mecanismos dirigem a adaptação da pronúncia de L2. Em particular, as questões que geram discussão dizem respeito ao fato de se a adaptação de empréstimo existe em função da percepção ou da produção e se os processos de adaptação são fonológicos em natureza ou sensíveis a detalhes fonéticos da língua fonte.

Além da distinção dos cenários em que ocorre o empréstimo e sua adaptação, há também uma outra distinção no que se refere às palavras emprestadas. Muitos linguistas (SHINOHARA, 1997; KENSTOWICZ \& SOHN, 2001; PEPERKAMP \& DUPOUX, 2001) consideram importante diferenciar dois tipos de empréstimo: os históricos e as adaptaçôes on-line. Os empréstimos históricos são palavras que, após terem sido emprestadas, são comumente usadas por falantes monolíngues. Os falantes monolíngues que fazem uso dessas palavras emprestadas não tiveram contato com as formas fontes e, por essa razão, segundo Peperkamp \& Dupoux (2001), não há como supor uma forma subjacente que difira da forma do output em sua gramática. Um análise estritamente fonológica das adaptações

\footnotetext{
32 Nesse esquema de nativização, o tomador de empréstimo bilíngue primeiro produz a palavra em L2 e então usa essa representação de surpefície como input para o processo de nativização, que é fonológico. Se isso estiver correto, os modelos de estância perceptual e de estância fonológica não mais precisarão ser contrastados, e poderiam ser amplamente unificados: o input para nativização é sempre fonético, a palavra como é "ouvida". O tratamento, por uma lado, é sempre fonológico e pode ocorrer seja durante a percepção ou durante a produção.
} 
dessas palavras sofreria duras críticas, pois esse empréstimo linguístico não tem uma realidade mental. Por isso, convém uma interpretação diacrônica, na qual entende-se que as adaptações realizadas foram introduzidas pelos falantes que fizeram os empréstimos originalmente.

Um exemplo de uma análise baseada em empréstimos históricos pode ser vista na tese de doutorado, ainda em andamento, feita por Freitas (no prelo), em que são estudadas palavras pertencentes ao léxico básico do papiamentu que foram provenientes de línguas ibéricas, em especial do português e do espanhol. Ainda hoje o espanhol exerce influência sobre o papiamentu, devido à contiguidade e à presença de hispanofalantes na ilha. Influência essa que o português não mais tem sobre a língua nativa comparado ao período de formação do papiamentu. O estudo de Freitas concentra-se em uma análise diacrônica em que, através de pesquisas etimológicas, a linguista pode observar as adaptações de empréstimo ocorridas no passado da língua.

O segundo tipo de empréstimos, as adaptações on-line, é constituído por palavras estrangeiras que são emprestadas "aqui e agora" (SHINOHARA, 1997; KENSTOWICZ \& SOHN, 2001). Tal empréstimo, além de ser recente, ocorre em contextos em que os falantes nativos têm acesso à forma original. Para Peperkamp \& Dupoux (2001), é possível estudar os dois tipos de empréstimo em conjunto, assumindo, para tanto, que os empréstimos históricos refletem adaptações on-line feitas por falantes que outrora introduziram essas palavras.

\subsubsection{Adaptação através da percepção}

No tocante ao papel da percepção na adaptação, tem-se o modelo desenvolvido por Best, Womer \& Queen (1994) chamado de Modelo de Assimilação Perceptual (MAP). O MAP tem como objetivo explicar os efeitos da experiência da língua materna (L1) na percepção 
de contrastes fonéticos da L2. Esse modelo parte do pressuposto de que os segmentos da L2 tendem a ser percebidos de acordo com suas semelhanças e diferenças com os padrões articulatório-gestuais mais próximos das categorias da L1.

De acordo com Best, Womer \& Queen (1994), o segmento não nativo pode ser percebido sob três formas distintas que estão sujeitas à distância entre os segmentos da L1 e da L2 no espaço fonológico nativo: (i) como segmento categorizável, no qual as invariantes gestuais das duas línguas podem ser notadas como semelhantes, sendo que neste caso o som de L2 é assimilado numa categoria da L1; (ii) como segmento incategorizável, no qual o som da L2 é percebido como um gesto de fala, mas sua organização não é assimilada a nenhuma categoria específica de L1; e (iii) como não-assimilável, no momento em que o segmento da L2 não é percebido como um som de fala, a sua organização gestual ocupa uma área externa ao espaço fonológico nativo, não sendo, por sua vez, assimilado a qualquer categoria de L1 (BEST, WOMER, QUEEN, 1994).

Para entender melhor a perspectiva desenvolvida pelo MAP, primeiramente é necessário se ter em mente o conceito de substituição diferencial. Tal conceito se relaciona às diferentes formas de realizações fonéticas de um mesmo segmento, quer numa mesma língua, quer em línguas diferentes. Um exemplo de substituição diferencial é o segmento / $\theta$ / presente no inglês que é geralmente substituído por [t] por falantes de francês canadense (BRANNEN, 2002), do português brasileiro (REIS, 2010), e substituído por [s] por falantes de francês europeu (BRANNEN, 2002) e de alemão (HANCIN-BHATT, 1994). Motivações perceptuais são indicadas como provável explicação para substituição diferencial de $/ \theta /$.

Defensores da corrente de empréstimo baseada na percepção, Peperkamp \& Dupoux (2001) criticam fortemente as abordagens sustentadas por regra e restrições (PARADIS, 1996). Os autores afirmam que há razões experimentais para acreditar que a suposição de que os falantes copiam fielmente a forma de output da língua fonte em seu léxico subjacente 
está errada. Para Peperkamp \& Dupoux (2001), há fidelidade, contudo ela é pesadamente influenciada pela língua nativa. Além disso, ouvintes/falantes têm dificuldade em perceber constrastes segmentais e suprasegmentais não nativos (BEST \& JONES, 1998).

Apesar da influência inegável da percepção no processo de nativização e adaptação de empréstimo, a percepção de fala é bastante complexa para ser entendida por uma única teoria (Cf. STERNBERG, 2003). Além disso, a abordagem baseada apenas na percepção generaliza, de forma equivocada, todos os cenários em que ocorre o empréstimo, uma vez que supõe que os falantes de L1 não possuem grande domínio do inventário fonológico de L2. Em outras palavras, tal abordagem faz análises baseadas em uma realidade linguística monolíngue. É claro que o empréstimo pode ser realizado por pessoas que falam apenas uma língua, contudo, no caso do papiamentu, tal realidade não se aplica. Além do papiamentu, os falantes da ilha de Curaçao possuem contato com outras três línguas que são o inglês, o holandês e o espanhol (STATISTICS, 2012). Logo, percebe-se que, no caso dos curaçolenhos, falantes multilíngues, não se pode propor um desconhecimento das formas de L2 emprestadas ao menos para o papiamentu moderno. Portanto, é necessário que as pesquisas desenvolvidas conforme a percepção não ignorem as línguas que convivem em um cenário multilinguístico, o que tem ocorrido frequentemente.

\subsubsection{Adaptação através da produção}

Os defensores de uma abordagem baseada apenas na produção afirmam que adaptação de empréstimo é fonológica por natureza e está apenas em função da gramática de produção

(Cf. PARADIS, 1996; PARADIS \& LACHARITÉ, 1997). Seguindo essa perspectiva, Paradis (1996) e Paradis \& LaCharité (1997) propõem a Teoria de Restrições e Estratégias de Reparos (TCRS).

Com a finalidade de investigar as estratégias usadas no processo de nativização, a partir 
da análise de quatro corpora constituídos de empréstimos, LaCharité \& Paradis (2005) coletaram 4.031 palavras emprestadas em quatro diferentes línguas: inglês no francês de Quebec e francês no àrabe marroquino, kinyarwanda e fula. A estatística geral indicou que o apagamento segmental é raro $(4,1 \%$ dos casos). O apagamento do segmento devido à presença de um segmento mal formado, isto é, por razões fonológicas, é ainda mais raro, com 2,3\% dos casos (Cf. LACHARITÉ \& PARADIS, 2005).

Paradis (1996) demonstra que segmentos mal formados contidos em empréstimos são adaptados, isto é, redistribuídos em formatos diferentes $(85,2 \%$ dos casos) ou se mantêm não adaptados (10,7\% dos casos) - se eles são importados - em vez de serem apagados. O apagamento de segmento induzido fonologicamente representa apenas $2,3 \%$ dos casos, um fato que é atribuído ao princípio da Teoria de Restrições e Estratégias de Reparos (TCRS) (PARADIS, 1988), o Princípio da Preservação. Tal Princípio estabelece que a informação segmental não é arbitrariamente destruída (PARADIS, 1996):

(2) Princípio da Preservação: A informação segmental é maximamente preservada, dentro do Princípio do Limiar.

O resgate de um segmento (ou seja, ao menos seu nó de raiz) falha somente quando sua retenção seria muito custosa. O Princípio do Limiar (PARADIS, 1996) postula que todas as línguas impõem um limite para preservação do segmento. O limiar de modificações é um conjunto de dois passos. Uma vez que a preservação de segmentos excede o limiar, o apagamento ocorrerá, como no caso de um segmento que é ausente no inventário nativo e, entretanto, está em uma posição fonotática ilícita.

Alguns outros estudos propõem uma análise da adaptação de empréstimo orientada pela produção com base na Teoria da Otimalidade (OT) (PRINCE \& SMOLENSKY, 1993; MCCARTHY \& PRINCE, 1994). O pressuposto básico da OT é que cada output linguístico 
é ótimo, no sentido de que ele incorre violações mínimas de um conjunto de restrições conflitantes. Por um dado input, a gramática gera e então avalia um conjunto infinito de candidatos a output, do qual a gramática seleciona o candidato ótimo, que é o output atual. A avaliação acontece em um conjunto de restrições hierarquicamente classificadas em um ranking, cada uma pode eliminar alguns outputs candidatos até o ponto em que apenas um candidato a output sobrevive. O candidato ótimo é aquele que é mais harmônico com respeito a um conjunto de restrições classificadas por ranking. "Harmonia" é um tipo de boa-formação relativa, levando em conta a severidade das violações de restrições individuais, como determinado pelo ranking de hierarquia (Cf. KAGER, 1999).

Em outras palavras, de acordo com Kager (1999), a violação de uma restrição acima na classificação implica uma custo maior à harmonia do que a violação de restrição abaixo no ranking. Por conseguinte, uma restrição abaixo no ranking pode ser violada para evitar a violação de uma restrição mais alta, mas a violação é sempre evitada ao máximo, devido ao requisito de harmonia máxima.

Por definição, restrição é um requisito estrutural que pode ser ou satisfeito ou violado por uma forma de output. Uma forma satisfaz uma restrição se ela atende, de alguma maneira, à exigência estrutural. Quando uma forma não atende a essa exigência, afirma-se que há violação. A OT reconhece dois tipos de restrições, as restrições de marcação e de fidelidade. Cada restrição individual avalia um aspecto específico da marcação ou fidelidade do output. Restrições de marcação exigem que formas de output atendam a algum critério de boa formação estrutural. Restrições de fidelidade exigem que outputs preservem as propriedades de suas formas (lexicais) básicas, exigindo algum tipo de similaridade entre output e seu input. Restrições de fidelidade são, estritamente falando, restrições de outputs "não puras", desde que elas levam em conta elementos em dois níveis: input e output. Em 
contraste, restrições de marcação jamais levam em conta elementos no input (KAGER, 1999: 4-10).

Em um contexto de empréstimo, segundo a perspectiva da OT, se a palavra emprestada estiver de acordo com o formato silábico e prosódico da língua nativa e não desrespeitar nenhuma regra fonotática em L1, espera-se que tal palavra seja preservada o máximo possível em seu formato fonológico. Essa preservação ocorre, uma vez que o ranking de restrições de L1 não sofreu alteração, pois não houve violação de restrição ou também porque ocorreu uma similaridade entre o input e output, que são a forma fonte (L2) e a palavra emprestada na L1, respectivamente. No entanto, se um empréstimo possui um formato silábico ilícito em L1, ocorre obviamente violações de restrições do inventário nativo. No momento em que ocorre violação, a forma ótima é escolhida tendo como base a hierarquia no ranking de regras de L1. Assim, a forma emprestada (input) é adaptada, levando em considerações tal ranking. A forma que viola o menor número possível de regras é escolhida como output, que é o segmento emprestado adaptado.

Como bem afirma Peperkamp \& Dupoux (2001), muitos aspectos não podem ser explicados por uma ótica puramente fonológica, uma vez que algumas adaptações não são fonologicamente motivadas. Em línguas com epêntese vocálica em palavras emprestadas, por exemplo, a escolha da vogal epentética não seria motivada pela fonologia segundo os estudiosos. De acordo com Shinohara (1997), em empréstimos, o japonês usa principalmente o [u] como elemento epentético, já o português brasileiro utiliza o [i] em palavras emprestadas de acordo com Parlato-Oliveira (2007). Para Peperkamp \& Dupoux (2001), não haveria motivo para afirmar que tanto o [u] quanto o [i] sejam fonologicamente vogais não marcadas no japonês e no português brasileiro.

Diante desses exemplos de irregularidade na adaptação, é possível concluir que uma análise que apenas considere regras e restrições fonológicas como únicas responsáveis no 
processo complexo que é a nativização de empréstimo estará limitada. Tendo em vista que, em muitas línguas, as restrições operam de uma forma em palavras nativas e de outra em palavras emprestadas, é necessário conjugar outros fatores que não apenas o fonológico na análise de empréstimo.

\subsubsection{Adaptação através da percepção e produção}

Uma outra forma de explicar a adaptação de empréstimos considera tanto a percepção, quanto a produção, contudo as aborda em níveis separados regidos por gramáticas distintas (KENSTOWICZ, 2003b). Entre os pesquisadores dessa frente de análise, é consesual que os falantes da língua recipiente não têm acesso à pronúncia da língua doadora. O input para os processos no nível de produção é o output do nível de percepção e daí uma forma modificada da pronúncia fonte.

Kenstowicz (2003b) afirma que, na adaptação de empréstimos do francês em fon, as gramáticas da percepção e da produção consistem em hierarquias de restrições distintas. Na gramática da percepção, a restrição contra a inserção vocálica (Dep-V) tem prioridade mais alta do que o apagamento consonantal (Max-C), o que torna possível para as consoantes serem apagadas no nível de percepção (ex. "poste" /post/ > /pos/). Na gramática de produção, Max-C domina Dep-V, o que motiva a preferência pela inserção da vogal em detrimento do apagamento da consoante no nível de produção (ex. /pos/ > /posu/).

Embora essa corrente tenha o benefício de unir, mesmo que em níveis distintos, a produção e a percepção e, por sua vez, a fonologia e a fonética, ela comete o mesmo equívoco das correntes perceptuais e de produção que é o de ignorar o bilinguismo. Afirmar que os falantes, em um empréstimo, jamais têm acesso à pronúncia de L2 é demasiadamente limitado para realidades linguísticas como as de Curaçao, em que há a coexistência de duas ou mais línguas. 


\subsubsection{Adaptação baseada na similaridade perceptual}

Fleischhacker (2001, 2002), Steriade (2002) e Walker (2003) integram a similaridade perceptual à gramática de produção. Os estudos que seguem essa linha defendem que os processos de empréstimo tendem a maximizar a similaridade perceptual entre a forma adaptada e o input estrangeiro (KANG, 2003; KENSTOWICZ, 2003a; ADLER, 2004).

Sobre as adaptações das palavras do inglês em fiji, Kenstowicz (2003a) argumenta que a saliência auditiva e a similaridade possuem um papel crucial. Segmentos ou estruturas salientes tendem a ser preservados em processos de adaptação e, quando reparos são necessários, modificações serão evitadas o quanto possível.

Outro estudo desenvolvido sob essa perspectiva é o feito por Kang, Kenstowicz \& Ito (2008). Eles apresentam, em um artigo, os principais resultados de um estudo com mais de quinhentas palavras emprestadas do inglês, com influências do japonês, para o coreano. Foi examinada a distribuição de dez características fonológicas de empréstimos influenciados pelo japonês. Os resultados gerais demonstram que os traços do japonês que pertencem às vogais não-epentéticas são mais propensos a serem mantidos do que aqueles que pertencem à epêntese vocálica e consonântica. Assim, Kang, Kenstowicz \& Ito (2008) observaram que houve retenções diferenciais de traços do japonês (KANG, KENSTOWICZ \& ITO, 2008: 314). Segundo Kang, Kenstowicz \& Ito, as características do japonês são mais facilmente eliminadas nos contextos em que os falantes do coreano estão mais seguros de que não é um padrão aparente de empréstimo do inglês.

A corrente baseada na similaridade perceptual, ao aliar os dois níveis de percepção e produção, oferece novas possibilidades de pesquisas linguísticas, uma vez que não restringe o estudo de empréstimo a apenas um nível. Diante da complexidade envolta no processo de empréstimo, nem sempre é possível explicá-lo usando apenas regras fonológicas de restrição (produção) ou relacionando a adaptação às saliências perceptuais (percepção). Além disso, 
não se pode atribuir ao falante de L1 um papel passivo no processo de adaptação, uma vez que o adaptador não é um recipiente passivo do módulo da percepção de fala, mas exerce controle ativo sobre a gramática nativa ao formatar o empréstimo, assim como possivelmente recorre ao conhecimento implícito da similaridade fonética para adaptações de forma que carecem de um precedente no sistema nativo (Cf. KENSTOWICZ, 2004).

O processo de adaptação pode também levar em conta uma variedade de fatores para encontrar a melhor combinação para a palavra fonte. Um desses fatores pode ser a grafia, uma vez que os empréstimos podem ser pensados não só sob a ótica de sua integração fonética, fonológica e morfológica, mas também sob a perspectiva da sua integração através de signos gráficos. Há casos em que itens lexicais são adaptados via escrita e, a partir dela, espraiam-se pela língua, seguindo regras que ligam a escrita à pronúncia. Segundo Roth (1980), esse aspecto tem sido negligenciado pelos linguistas. De acordo com o estudioso, a inobservância da influência da escrita na adaptação de empréstimo se deve ao papel marginal que a grafia desempenha nos estudos linguísticos em geral.

Roth (1980: 167-168), ao falar sobre a influência da representação gráfica na acomodação do empréstimo, afirma que a própria grafia do inglês pode facilitar ou dificultar a assimilação no português do Brasil. Um amostra da punjança da escrita sobre a adaptação de empréstimo é a palavra fricot [fRi'ko] do francês que foi nativizado no português como fricote [fri'kst $\left.\int \mathrm{I}\right]$. Tal palavra foi nativizada provavelmente através da escrita, uma vez que a pronúncia da forma adaptada se aproxima muito mais da grafia do item lexical francês do que da sua realização fonética. O mesmo não ocorre com a palavra tricot [tRi'ko] também do francês, que é adaptada para o português como tricô [tri'ko]. Observa-se que o referido item se assemelha à forma como se pronuncia no francês, afastando-se de sua realização gráfica, o que nos leva a concluir que o empréstimo desse item ocorreu através da oralidade, e não via escrita. 
Diante disso, essa dissertação objetiva discutir os padrões de adaptação de empréstimo no papiamentu moderno a partir da perspectiva não só da similaridade perceptual, mas também do papel das restrições fonológicas no processo de adaptação (PARADIS, 1988). Seguindo teóricos como Kang (2003), podemos supor que a fonologia de empréstimo produz uma forma adaptada que é percebida pelos falantes da língua recipiente como a mais similar à pronúncia da forma fonte. No entanto, para este estudo, considera-se que a adaptação e a busca pela maior similaridade são também regidas pelas restrições fonotáticas existentes no inventário fonológico nativo. 


\section{Capítulo 4}

\section{Análise dos dados}

Com base nos conceitos teóricos discutidos no capítulo $\mathbf{3}$ e tendo em vista também as características principais dos sistemas vocálico, consonantal e silábico do papiamentu vistos no capítulo 2, neste capítulo, será analisado como tem sido feita a adaptação fonológica e morfológica em palavras oriundas de empréstimos recentes de outras línguas (português, espanhol, holandês e inglês) para o papiamentu.

No capítulo 1, vimos que o corpus foi constituído por itens lexicais dos campos do Esporte, Política, Economia, Tecnologia e Desenvolvimento, que, primeiramente, foram retirados de materiais escritos em papiamentu, como o jornal impresso Exxtra, produzido e vendido em Curaçao; manuais e livros de esporte (COSTER, 2010; PERSAUD, 1992; DANIELS, 1986); guias e livros sobre economia e politica (HEILIGERS-HALABI, 1988; SINDIKATONAN, 1985; KOMERSIO, 1996; HOYER, 1944); dicionário bilíngue papiamentu/inglês (RATZLAFF-HENRIQUEZ, 2008). Com os itens lexicais devidamente selecionados, iniciou-se o processo de gravação dos dados, em que falantes nativos de papiamentu liam e pronunciavam, da maneira mais natural possível, os itens lexicais, dispostos em material escrito. As palavras foram lidas pausadamente e de forma isolada. Após a gravação dos dados, foram utilizados, como metodologia de análise, padrões de correspondência de som entre palavras do papiamentu e os itens de empréstimo de outras línguas ${ }^{33}$.

${ }^{33}$ A pesquisa coletou 930 itens lexicais para a constituição do corpus. No entanto houve 27 dados 
Para que os itens lexicais de adaptação recente sejam analisados, é preciso que, antes, sejam discutidas as fontes lexicais desses itens (seção 4.1) e as restrições relacionadas ao processo de nativização, o que será feito na seção 4.2. Em seguida, serão descritos os padrões encontrados na análise dos dados e os processos segmentais mais frequentes no corpus (seção 4.3). Na seção 4.4, discutir-se-ão alguns aspectos a respeito do inventário fonológico do papiamentu, tais como o estatuto fonêmico da fricativa labiodental sonora [v] (subseção 4.4.1) e das vogais arredondadas $[\varnothing]$ e $[y]$ (subseção 4.4.2). Na seção 4.5, serão descritos os processos morfológicos envolvidos na criação de itens lexicais no papiamentu, tais como a derivação através da adição de sufixos e a nativização de itens por meio do processo de decalque. Posteriormente, serão vistos os itens nativizados, que se encontram em variação no vocabulário do papiamentu (seção 4.6). Na seção 4.7, alguns aspectos no tocante à grafia e as dificuldades encontradas na padronização dos itens de entrada lexical recente, frutos de empréstimo, serão demonstrados. Por fim, na seção 4.8, será realizada uma síntese da discussão empreendida ao longo do capítulo.

\subsection{Fontes lexicais}

Na Tabela 4.1, encontra-se, em números, o resultado obtido na definição do étimo dos vocábulos de empréstimo recente. Na Tabela 4.2, encontram-se discriminados os dados que têm a possibilidade de provir de mais de um étimo. Quanto à organização das informações, é importante dizer que, na primeira coluna, estão as línguas fontes das quais os itens de adaptação recente foram tomados de empréstimo, são elas: espanhol, holandês,

aos quais não foi possível atribuir um étimo provável. Em muitos desses itens, embora houvesse uma palavra próxima em uma das línguas fontes, não havia uma relação semântica entre o provável étimo e a palavra no papiamentu, como os itens ganashi ${ }_{946}$ "gasto", shòbel ${ }_{954}$ "embaralhar", fungo g $_{45}$ "forma de bater a bola". Diante disso, optou-se, no presente estudo, pelo não estabelecimento do étimo. Esses 27 itens encontram-se elencados no final do apêndice, a partir do número 931 (ver apêndice $\mathbf{A}$ ). 
inglês, espanhol/português, português e francês. Na primeira linha, estão distribuídos, respectivamente, os campos de Esporte, Economia, Tecnologia e Desenvolvimento e Política. Assim, em cada coluna correspondente ao campo lexical, há o número de dados obtidos em cada língua ou em cada conjunto de línguas (caso da Tabela 4.2).

Tabela 4.1: Prováveis fontes lexicais de empréstimo do papiamentu

\begin{tabular}{|l|l|l|l|l|l|}
\hline $\begin{array}{l}\text { Lingua/ } \\
\text { Campo lexical }\end{array}$ & Esporte & Economia & Tecnologia & Política & $\begin{array}{l}\text { Total abso- } \\
\text { luto }\end{array}$ \\
\hline \hline ESP $/$ POR & $\mathbf{9 9}(29,2 \%)$ & $\mathbf{1 1 4}(49,1 \%)$ & $\mathbf{1 2 0}(40,7 \%)$ & $\mathbf{2 1}(72,4 \%)$ & $\mathbf{3 5 4}(39,6 \%)$ \\
\hline Espanhol & $\mathbf{1 0 2}(30,1 \%)$ & $\mathbf{8 0}(34,4 \%)$ & $\mathbf{6 5}(22,2 \%)$ & $\mathbf{6}(20,6 \%)$ & $\mathbf{2 5 3}(28,3 \%)$ \\
\hline Holandês & $\mathbf{5 7}(17 \%)$ & $\mathbf{2 8}(12 \%)$ & $\mathbf{7 3}(24,7 \%)$ & $\mathbf{2}(7 \%)$ & $\mathbf{1 6 0}(18 \%)$ \\
\hline Inglês & $\mathbf{7 7}(23,2 \%)$ & $\mathbf{9}(4 \%)$ & $\mathbf{3 4}(11,7 \%)$ & - & $\mathbf{1 2 0}(13,5 \%)$ \\
\hline Português & $\mathbf{2}(0,5 \%)$ & - & $\mathbf{2}(0,7 \%)$ & - & $\mathbf{4}(0,5 \%)$ \\
\hline Francês & - & $\mathbf{1}(0,5 \%)$ & - & - & $\mathbf{1}(0,1 \%)$ \\
\hline Total & $\mathbf{3 3 7} / \mathbf{8 9 2}$ & $\mathbf{2 3 2} / \mathbf{8 9 2}$ & $\mathbf{2 9 4} / \mathbf{8 9 2}$ & $\mathbf{2 9} / \mathbf{8 9 2}$ & $\mathbf{8 9 2}(100 \%)$ \\
\hline
\end{tabular}

Tabela 4.2: Itens com mais de um étimo possível

\begin{tabular}{|l|l|l|l|l|l|}
\hline Linguas/Campo lexical & Esporte & Economia & Tecnologia & Política & Total \\
\hline \hline Espanhol + Holandês & $\mathbf{3}$ & $\mathbf{2}$ & $\mathbf{5}$ & $\mathbf{1}$ & $\mathbf{1 1}$ \\
\hline Holandês + ESP/POR & $\mathbf{1}$ & $\mathbf{2}$ & $\mathbf{7}$ & - & $\mathbf{1 0}$ \\
\hline Holandês + Inglês & $\mathbf{6}$ & - & - & - & $\mathbf{6}$ \\
\hline Espanhol + Inglês & $\mathbf{4}$ & - & - & - & $\mathbf{4}$ \\
\hline Inglês + ESP/POR & $\mathbf{2}$ & - & - & - & $\mathbf{2}$ \\
\hline ESP/POR + Espanhol & - & $\mathbf{1}$ & - & - & $\mathbf{1}$ \\
\hline ESP/POR+Espanhol + Holandês & $\mathbf{1}$ & - & - & - & $\mathbf{1}$ \\
\hline Inglês/Português & $\mathbf{1}$ & - & - & - & $\mathbf{1}$ \\
\hline Holandês/Português & $\mathbf{1}$ & - & - & - & $\mathbf{1}$ \\
\hline Holandês/Sueco & - & - & $\mathbf{1}$ & - & $\mathbf{1}$ \\
\hline Total & $\mathbf{1 9 / 3 8}$ & $\mathbf{5 / 3 8}$ & $\mathbf{1 3 / 3 8}$ & $\mathbf{1} / \mathbf{3 8}$ & $\mathbf{3 8}$ \\
\hline
\end{tabular}

Antes de analisar os resultados obtidos, é preciso tecer algumas considerações sobre o número de dados. Foram coletados 930 itens relativos a empréstimos recentes. Desse número total, pôde-se traçar, em 892 palavras, uma única língua fonte (ver Tabela 4.1), enquanto que 38 itens ou são palavras resultantes do processo de hibridismo, em que o item lexical é formado por palavras fontes de duas ou mais línguas, ou possuem mais de um étimo possível (ver Tabela 1.2). A grande maioria dos itens lexicais analisados (892) 
apresentou apenas um étimo possível. Um exemplo desse conjunto de itens é a palavra bateadó $_{21}$ "batedor", que seguramente é uma adaptação da palavra bateador do espanhol. Alguns itens (38) foram formados a partir de palavras de línguas fontes diferentes, como na palavra hür di edifisio 910 "seguro de edifício" que é formada pela palavra huur "seguro" do holandês e edifício/edificio do espanhol/português. Nesse conjunto de 38 itens, há também palavras a que se pode ser atribuído mais de um étimo possível, como na palavra coach $_{921}$ "técnico", que pode ser proveniente de coach do inglês ou coach do holandês.

Ao analisar a Tabela 4.1, é possível verificar que o espanhol e o português ainda se mantêm prevalecentes no léxico do papiamentu. Em todos os campos lexicais, se se analisarem os números obtidos pelo espanhol/português ${ }^{34}$ juntamente com o português e o espanhol isoladamente, constata-se que os últimos foram as línguas fontes das quais o papiamentu tomou mais itens lexicais de empréstimo. No campo do Esporte, nota-se que, dos 337 dados, 99 vocábulos são provenientes do espanhol/português (29,2\%), 102 itens são emprestados do espanhol $(30,1 \%)$ e 2 itens certamente são provenientes do português $(0,5 \%)$, representando cerca de $59,8 \%$ do total, ao serem somados todos esses dados. A hipótese levantada por Martinus (1990:134) de que estaria ocorrendo uma hispanização em campos semânticos inteiros exige cautela, sobretudo no campo esportivo, em que o inglês $(23,2 \%)$ e o holandês (17\%) ainda exercem certo predomínio com 134 dados somados, representando $40,2 \%$ do total.

No campo da Economia, de um total de 232 palavras, os itens do espanhol/português demonstraram um predomínio ainda maior do que ocorreu no campo de Esporte, com 34,4\% para o espanhol, 49,1\% para o espanhol/português, demonstrando um predomínio quase absoluto com 83,5\% do total, somando-se os dados supracitados. Tal preponderância

\footnotetext{
${ }^{34}$ Muitas vezes, o étimo da palavra não pôde ser atribuído somente ao espanhol, mas também ao português, por essa razão preferiu-se utilizar a nomenclatura espanhol/português nesses casos.
} 
do espanhol/português em palavras referentes à economia pode ser melhor entendida devido à própria proximidade com o mundo espanhol e por causa dos fortes laços comerciais com a Venezuela e Colômbia, sobretudo devido à contiguidade.

No campo da Tecnologia e Desenvolvimento, encontrou-se novamente um predomínio do espanhol/português, com a porcentagem de $62,9 \%$ se forem somados as porcentagens obtidas pelo espanhol/português, espanhol e português, isoladamente. Contudo não se pode ignorar a presença significativa de palavras do inglês e do holandês, que juntos representam $36,4 \%$ do total. A alta porcentagem de palavras do espanhol/português pode ser explicada pelas mesmas razões por que houve uma maior presença desse étimo em itens da economia: proximidade comercial e revolução econômica. Dois fatores que estão ligados intrinsecamente ao maior desenvolvimento tecnológico e, como consequência, a uma ampliação do léxico relacionado à tecnologia. Quanto ao inglês e holandês, já era esperado que ambos tivessem participação em itens relacionados ao mundo tecnológico, uma vez que o primeiro é uma língua de grande alcance mundial e usada como meio de interação entre grandes corporações na criação de programas de computação e similares. Já o holandês foi não só a língua do colonizador, mas também foi, durante muito tempo, a língua daqueles que pertenciam às classes econômicas mais altas em Curaçao e, por esse motivo, tais segmentos tinham maior acesso a bens tecnológicos. Esse maior acesso talvez tenha ajudado a promover uma maior proliferação de itens lexicais em holandês, tais como vidiorikòrder 399 "máquina filmadora" [fidiori'kohdeh], do holandês videorecorder.

No tocante ao domínio lexical da Política, embora tenha havido um número expressivo de palavras do espanhol e do português, com 93\% do total, não é possível afirmar, com tão poucos vocábulos, o predomínio do espanhol/português também nesse campo. 


\subsection{As restrições na nativização/adaptação de empréstimo}

Kenstowicz (2003a) afirma que segmentos ou estruturas salientes tendem a ser preservadas em processos de adaptação e, quando reparos são necessários, modificações serão evitadas o quanto possível. Seguindo essa mesma linha, está Paradis (1996) que defende um conceito chamado Princípio de Preservação, em (1). Tal princípio estabelece que a informação segmental não é arbitrariamente destruída (PARADIS, 1996):

(1) Princípio da Preservação: A informação segmental é maximamente preservada, dentro do Princípio do Limiar (Threshold Principle).

O Princípio do Limiar, em (2), postula que todas as línguas impõem um limite para preservação de segmentos, tal princípio não excede dois processos dentro de um dado domínio de restrição.

(2) Príncipio do Limiar: Todas as línguas têm um limiar de tolerância para a preservação do segmento. Esse limiar é estabelecido em dois passos (ou dois reparos) dentro de um dado domínio de restrição (PARADIS \& LACHARITÉ, 1997).

Além disso, há também a Estratégia de Reparo, definida em (3).

(3) Estratégia de Reparo: Operação fonológica não contextual ${ }^{35}$ e universal que é engatilhada por uma violação de uma restrição fonológica e que insere, apaga segmento ou estrutura para garantir a conformidade com a restrição (PARADIS, 1996).

O Princípio de Preservação se aplica ao papiamentu, pois em palavras, fruto de empréstimo, que possuem estrutura silábica e fonemas semelhantes à língua crioula, nota-se que o vocábulo se manteve bastante similar ou mesmo idêntico:

\footnotetext{
35 A caracterização da estratégia de reparo como não contextual demanda cautela, uma vez que, no caso da apócope do -r em palavras terminadas em -dó em papiamentu, a estratégia foi contextual, ou seja, ocorreu sempre em final de palavra.
} 
Tabela 4.3: Palavras adaptadas ao papiamentu que sofrem pouca ou nenhuma alteração.

$\begin{array}{lll}\text { PAPIAMENTU } & E S P / P O R & \text { GLOSA } \\ \text { 4. } \text { Aporte }_{551} & \text { Aporte } & \text { "Aporte" } \\ \text { [a'pohte] } & \text { [a'porte] / [a'pohti] } & \\ \text { 5. Tarifa } & \text { Tarifa } & \text { "Tarifa" } \\ \text { [ta'rifa] } & \text { [ta'rife] } & \\ \text { 6. Atleta } 561 & \text { Atleta } & \text { "Atleta" } \\ \text { [a'tleta] } & \text { [a'tleta] / [a'tlete] } & \\ \text { 7. Logístiko } & \text { Logístico } & \text { "Logístico" } \\ \text { [lo'histiku] [lo'xistiku] } & \text { [lo'xistiko] / [lo'zist fikv] } & \end{array}$

Nos exemplos (4) e (5), nota-se que houve uma manutenção dos segmentos da(s) palavra(s) fonte(s), excetuando-se os róticos, em (4), que estão sujeitos à variação em sua realização fonética no espanhol e no português, nesse item, o papiamentu opta pela realização glotal [h]. O exemplo (6) apresentou uma realização fonética mais similar à realização no espanhol do que no português, devido à presença da vogal média alta $([\mathrm{e}])^{36}$. Em (7), uma variação que chama atenção entre as duas possíveis palavras fontes e a forma adaptada no papiamentu é a realização do [y]. No português, o grafema $<\mathrm{g}>$ pronuncia-se como pós-alveolar [3], no espanhol, pronuncia-se como velar [x] e, no papiamentu, realizouse tanto como glotal surda [h], quanto como velar [x]. Segundo Lipski (2007), o $<\mathrm{r}>$ pode ser pronunciado como $[\mathrm{h}]$ ou $[\mathrm{x}]$ no espanhol falado na zona caribenha, incluindo a costa do México, Colômbia e Venezuela, sendo um traço característico dessa região.

Por outro lado, ao serem analisadas as palavras que sofreram alterações no processo de nativização, nota-se que o apagamento ocorreu com menor frequência, contudo de forma bastante pontual e com a mesma finalidade: evitar a violação de uma restrição no papiamentu. Em todos os verbos no infinitivo e nomes formados pelo nominalizador deverbal

36 Tal vogal não se constitui evidência suficiente para conjecturar um étimo espanhol, uma vez que pode ter havido um fechamento da vogal média baixa $([\varepsilon]>[\mathrm{e}])$ se tal palavra for proveniente do português. 
$<-d o r>$, todos do espanhol/português, notou-se o apagamento do segmento sonoro final de palavra $^{37}$, nesse caso o -r final, como se observa de (8-10):

Tabela 4.4: Itens lexicais do espanhol que foram submetidos ao processo de apagamento do $<\mathrm{r}>$.

\begin{tabular}{|c|c|c|}
\hline PAPIAMENTU & Espanhol & Glosa \\
\hline $\begin{array}{l}\text { 8. Adiestrad } \boldsymbol{o}_{2} \\
\text { [adjestra'do] }\end{array}$ & Adiestrador [aðjestra'ðor] & "Treinador" \\
\hline $\begin{array}{l}\text { 9. Bateadó } \\
\text { [batea'do] }\end{array}$ & $\begin{array}{l}\text { Bateador } \\
\text { [batea'ðor] }\end{array}$ & "Batedor" \\
\hline $\begin{array}{l}\text { 10. Entrenad } \boldsymbol{o}_{92} \\
\text { [ẽtrena'do] }\end{array}$ & Entrenador [entrena'ðor] & "Treinador" \\
\hline
\end{tabular}

Assim, podemos conjecturar uma regra de conversão que, nesse caso, pode ser estabelecida da seguinte forma:

(11) Em nomes formados por agentivos -dó e verbos no infinitivo de étimo espanhol/português, aplica-se a seguinte regra: $\mathbf{r} \#>\emptyset$

Exemplo: Arbitrar (espanhol/português) > Arbitrá552 (papiamentu)

Em termos de restrição, o parâmetro negativo ${ }^{38}$ em relação ao segmento final -r poderia ser o seguinte:

(12) Parâmetro: Consoante [r] em posição final de palavra?

português: Sim

espanhol: Sim

papiamentu: Não

\footnotetext{
37 Viaro (2011) já havia observado quanto os processos de apócope são comuns não só no português, como também no papiamentu: "Outros -r de nomes e verbos também desapareceram, mas têm distribuição variada e são menos aceitos na norma culta brasileira. O mesmo ocorre com os -1 e os -s: Essas apócopes também foram testemunhadas em muitos outros lugares da Lusofonia (no falar barraquenho, em Macau, no malaio-português, assim como no papiamento) [...]." (VIARO, 2011: 154).

38 Os parâmetros relacionados ao papiamentu, aqui expostos, foram postulados a partir da análise dos dados e com base em Paradis (1996) e Paradis \& Lacharité (1997).
} 
Nos itens analisados por esta pesquisa, não foi encontrada a fricativa labiodental sonora $(/ \mathrm{v} /)$ em nenhuma posição silábica. ${ }^{39}$ Em relação à existência da fricativa labiodental nas línguas emprestadoras (português, espanhol, holandês e inglês), foram estabelecidos os parâmentros em (13) e (14):

(13) Parâmetro: Fricativa labiodental sonora em posição de onset?

português: Sim

espanhol: Não

holandês: Sim

inglês: Sim

(14) Parâmetro: Fricativa labiodental sonora em posição de coda?

português: Sim

espanhol: Não

holandês: $\operatorname{Sim}^{* 40}$.

inglês: Sim

$\mathrm{Na}$ análise dos dados, observou-se uma adaptação categórica do segmento fricativo sonoro, em que uma Estratégia de Reparo foi acionada através da substituição da fricativa sonora pelas obstruintes surdas. Nos exemplos, em (15), houve uma nova estruturação (v $>\mathbf{f})$. De $\mathbf{a}-\mathbf{b}$, há apenas exemplos de itens que foram emprestados do inglês, uma vez que apenas as palavras desse étimo possuem seguramente a realização fonética dessa consoante (dirv]e e scuba di[v]er).

39 Sobre o estatuto do [v], ver subseção 4.4.1.

$40 \mathrm{O}$ holandês possui nove fricativas: $/ \mathrm{f} /, / \mathrm{v} /, / \mathrm{s} /, / \mathrm{z} /, / \mathrm{f} /, / 3 /, / \mathrm{x} /, / \mathrm{y} / \mathrm{e} / \mathrm{h} /$. Segundo Loo \& Smit (2008), as fricativas desvozeadas são permitidas em posição inicial, medial e final (fier "orgulhoso", tafel "mesa", lief "doce"). Já as fricativas e outras obstruintes vozeadas não são permitidas em posição final de palavra (vier "quatro", haven "porto", *liev) (LOO \& SMIT, 2008: 15). 
$(15) * \mathrm{v}>\mathrm{f}$

$\begin{array}{lll}\text { INGLESS } & \text { PAPIAMENTU } & \text { GLOSA } \\ \text { a. Dive ['dajv] } & \text { Daif }_{424} & \text { "Mergulhar" } \\ \text { b. Scuba diver ['dajver] } & {\text { Scubadaif } \text { er }_{513}}^{\text {S }} & \text { "Mergulhador" }\end{array}$

Outra restrição no papiamentu está relacionada à impossibilidade de haver obstruintes sonoras ([b], [d], [g], [z], [v]) em posição de coda como em (16):

(16) i Parâmetro: Codas?

inglês: Sim

papiamentu: Sim

ii Parâmetro: Obstruintes sonoras em posição de coda?

inglês: Sim

papiamentu: Não

Mais uma vez, a Estratégia de Reparo é requerida, como em (17):

(17) d. $>$ t.

\section{INGLÊS PAPIAMENTU GLOSA}

Badminton Bat.men.tòn 39 "Badminton"

Na impossibilidade de haver obstruintes sonoras ([d], [b], [g], [z], [y]) em posição de coda, o papiamentu adapta tais segmentos de L2 como obstruintes surdas ([t], [p], [k], [s], [x]) respectivamente. É importante dizer que não é a sonoridade da consoante no onset seguinte que influencia o processo. Nos itens de (18) a (23), encontram-se exemplos dessa adaptação no papiamentu:

Os itens de (18) a (20) referem-se ao ensurdecimento das obstruintes em posição de coda não-final. No exemplo (18), a oclusiva bilabial sonora [b] foi adaptada para sua contraparte 
Tabela 4.5: Processo de ensurdecimento de obstruintes sonoras.

\begin{tabular}{|c|c|c|}
\hline & Coda não-final & \\
\hline PAPIAMENTU & $L 2$ & Glosa \\
\hline 18. Su[p].si.dio 844 & $\begin{array}{l}\text { Su/b]sídio } \\
(E S P / P O R)\end{array}$ & "Subsídio" \\
\hline 19. A[t].mi.nis.trá ${ }_{564}$ & $\begin{array}{l}\text { A/d]ministrar } \\
(E S P / P O R)\end{array}$ & "Administrar" \\
\hline \multirow[t]{2}{*}{ 20. A[t].mi.nis.tra.bel ${ }_{565}$} & $\begin{array}{l}\text { A/d]ministrável } \\
(E S P / P O R)\end{array}$ & "Administrável" \\
\hline & Coda final & \\
\hline 21. Kon.ta.bi.li.da[t $]_{149}$ & $\begin{array}{l}\text { Contabilida[d] } \\
\text { (espanhol) }\end{array}$ & "Contabilidade" \\
\hline 22. $\mathbf{L e}[\mathbf{k}]_{480}$ & $\begin{array}{l}L e[g] \\
\text { (inglês) }\end{array}$ & "Etapa" \\
\hline 23. Homeklu[p $]_{460}$ & $\begin{array}{l}\text { Home Clu/b] } \\
\text { (inglês) }\end{array}$ & $\begin{array}{l}\text { "Equipe que começa } \\
\text { primeiro (beisebol)" }\end{array}$ \\
\hline
\end{tabular}

surda [p]. Em (19) e (20), a oclusiva dental [d] é adaptada para [t]. Já os exemplos de (21) a (23) também demonstram o ensurdecimento das obstruintes com o diferencial de que tal processo ocorre em posição de coda final. Em (21), a oclusiva [d] é adaptada para [t]. Em (22), a consoante velar sonora [g] também é substituída, no papiamentu, pelo seu par surdo [k]. E, por fim, no item (23), a consoante oclusiva sonora [b] é substituída pelo [p].

Como esperado, a limitação se restringe apenas à sonoridade, pois não há violação de restrição em palavras emprestadas com obstruinte surda na coda, como se pode ver em kòrf.bal ${ }_{314}$ que é proveniente do holandês korfbal "corfebol (esporte)". Neste exemplo, percebe-se que a fricativa labiodental surda [f] foi mantida na mesma posição. Além disso, em todas as palavras do espanhol, em que havia a oclusiva velar surda na coda, como ele[k].ción "eleição", o papiamentu manteve a consoante, como nas palavras elekshon 74 "eleição" que é pronunciada [elek'fõ] e elektrifiká 75 "eletrificado", nativizada da palavra ele[k]trificado, que é pronunciada como [elektrifi'ka]. 


\subsection{Processos segmentais}

Ao analisar os itens pertencentes ao corpus, foi possível depreender um conjunto regular de processos fonológicos e morfológicos de adaptação de empréstimos. Nas subseções seguintes, serão descritas, primeiramente, as adaptações realizadas no nível segmental, tais como: ensurdecimento, palatalização, falsa iotização, velarização, assimilação, nasalização, alçamento, falso betacismo. Em seguida, serão vistos processos que ocorrem no nível silábico, como aférese, síncope, apócope, redução de ditongo, epêntese e metátese.

\subsubsection{Ensurdecimento}

Um processo regular no corpus foi o ensurdecimento de obstruintes em posição de coda, uma vez que, no papiamentu, duas restrições atuam nesse processo: (i) a não-manutenção da consoante fricativa labiodental sonora ([v]) na adaptação de empréstimo; (ii) a impossibilidade de haver obstruintes sonoras em posição de coda. Diante disso, ocorre a adaptação para um segmento surdo (ver exemplos 24-29). Ainda que o papiamentu seja bastante refratário à presença de obstruintes sonoras na referida posição silábica, não houve, na base de dados, ocorrências de apagamento do segmento sonoro equivalente.

Em (24) e (25), há a substituição da oclusiva dental sonora [d] por sua contraparte surda [t]. Em (26) e (27), nota-se que o papiamentu substituiu a oclusiva bilabial sonora [b] para uma oclusiva bilabial surda [p]. Em (28), ocorre a dessonorização da fricativa sonora [v] em posição de coda, o [v] é substituído por uma consoante com traços mais similares que, nesse caso, é a sua contraparte surda [f]. Por fim, no exemplo (29), a oclusiva velar sonora [g] é substituída pela consoante surda [k].

Itens lexicais, como félt 285 do holandês veld "campo" e rònt 355 "assalto, no pugilismo", do holandês rond não podem ser considerados exemplos de ensurdecimento ([d]> $[\mathrm{t}])$, uma vez que o grafema $<\mathrm{d}>$ é pronunciado já no holandês como [t]. Dessa maneira, pode-se 


\begin{tabular}{|c|c|c|}
\hline PAPIAMENTU & $L 2$ & Glosa \\
\hline 24. Han[t].granat 299 & $\begin{array}{l}\text { Han[d].granaat } \\
\text { (holandês) }\end{array}$ & $\begin{array}{l}\text { "Granada de } \\
\text { mão" }\end{array}$ \\
\hline 25. Hè[t].fon 456 & $\begin{array}{l}\text { Hea/d].phone } \\
\text { (inglês) }\end{array}$ & $\begin{array}{l}\text { "Fones de ou- } \\
\text { vido" }\end{array}$ \\
\hline 26. Homeklu[p] $]_{460}$ & $\begin{array}{l}\text { Home Clu[b] } \\
\text { (inglês) }\end{array}$ & $\begin{array}{l}\text { "Equipe que } \\
\text { começa pri- } \\
\text { meiro" (beise- } \\
\text { bol) }\end{array}$ \\
\hline 27. Su[p].sidiá 843 & $\begin{array}{l}\text { Su/b].sidiar } \\
(E S P / P O R)\end{array}$ & "Subsidiar" \\
\hline 28. Dai $[\mathbf{f}]_{424}$ & $\begin{array}{l}\text { Di[v]e } \\
\text { (inglês) }\end{array}$ & "Mergulhar" \\
\hline 29. $\mathbf{L e}[\mathbf{k}]_{480}$ & $\begin{array}{l}L e[g] \\
\text { (inglês) }\end{array}$ & "Etapa" \\
\hline
\end{tabular}

concluir que, neste dois exemplos, houve a nativização através da pronúncia, via oral. A oralidade foi o meio de nativização mais observado na análise dos dados. Em contrapartida, no papiamentu, há exemplos de palavras que foram nativizadas via escrita como amatúr $\mathbf{a}_{16}$ do espanhol amateur [ama'ter] que foi adaptada como [ama'tuh]. Nota-se que a palavra amatúr $_{16}$ se aproxima mais da forma escrita do espanhol do que da sua pronúncia, o que sugere uma adaptação via escrita. Segundo Roth (1980: 167-168), a nativização da palavra fricot [fRi'ko] do francês para fricote [fri'kst fI] no português é também um exemplo de adaptação por meio da escrita, haja vista que a pronúncia da forma adaptada se aproxima muito mais da grafia do item lexical francês do que da sua realização fonética (ver subseção 3.1.4).

O ensurdecimento das consoantes sonoras na coda foi categórico em todas as palavras adaptadas de L2 que possuíam tal segmento, contudo houve dois casos em que ocorreu o 
ensurdecimento em posição de ataque como em genera[d]or, do espanhol ${ }^{41}$ que resultou em genera[t]or 103 "gerador" e camina[d]a que é adaptada como kamina[t] $\mathbf{a}_{131}$ "caminhada". Nesse caso, não há uma razão fonotática aparente, uma vez que, em papiamentu, é possível que a oclusiva sonora dental ocupe a posição de onset.

\subsubsection{Palatalização}

A palatalização foi bastante recorrente na análise dos dados, sobretudo nos contextos em que a palavra fonte, proveniente do espanhol ou do espanhol/português, possuía o segmento fônico [ $\theta]$ ou [s] diante do glide [j], como nos itens de (30) a (33) ou, em contextos em que a palavra fonte apresentava encontros vocálicos formados por -ia ([ja]), como em (34). Nos itens de adaptação recente, observou-se a palatalização da fricativa, seja ela dental

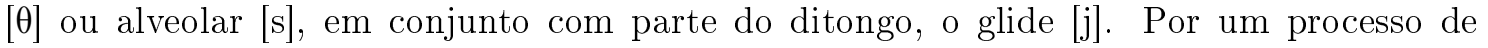
palatalização, -si torna-se -sh ([f]).

\begin{tabular}{|c|c|c|}
\hline PAPIAMENTU & L2 & Glosa \\
\hline 30. Vota[S]on 251 & 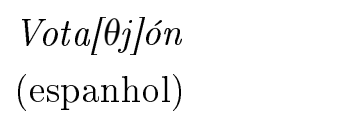 & "Votação" \\
\hline 31. Ehersita[f] $\operatorname{on}_{65}$ & $\begin{array}{l}\text { Ejercita }[\theta j] \text { on } \\
\text { (espanhol) }\end{array}$ & "Aptidão física" \\
\hline 32. Federa $\left[\int\right] \operatorname{on}_{96}$ & 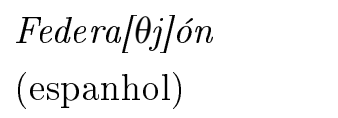 & "Federação" \\
\hline 33. Infrak[J]on 120 & 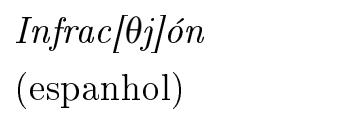 & "Falta cometida" \\
\hline 34. Interferen[$\left[\int\right] \mathbf{a}_{665}$ & $\begin{array}{l}\text { Interferên }[s j] /[\theta j] a \\
(E S P / P O R)\end{array}$ & $\begin{array}{l}\text { "Relativo ao bei- } \\
\text { sebol" }\end{array}$ \\
\hline
\end{tabular}

Com base na análise do corpus, observou-se a adaptação regular dos ditongos formados por -ia [ja], -io [jo], -iẽ [jẽ]. A adaptação desses ditongos ocorreu de duas maneiras: (a) a palatalização do -cia/sia $[\theta j \mathrm{j}]$ resultando em -sha $\left[\int \mathrm{a}\right] /$-cio $[\theta j o]$ resultando em -sho

${ }^{41}$ Segundo Lipski (2007: 392), no espanhol da zona dialetal do Caribe, existe uma tendência de que o -d mantenha sua pronúncia oclusiva antes de consoantes não-nasais. 


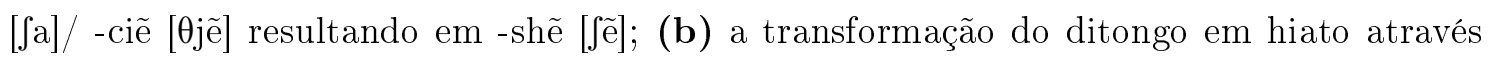
da ressilabificação (será discutido na seção 4.3). Exemplos de palatalização podem ser vistos no exemplo (34) e na palavra elektricien, do holandês, "eletricista" que é nativizada elektrishèn 273 .

Embora o segmento -shon esteja bastante presente no corpus, devido ao número significativo de palavras do espanhol que terminam em - ción que foram, por sua vez, adaptadas conforme dito no parágrafo anterior, não foi observado o uso do -shon como um sufixo derivacional. Todas as palavras com essa terminação em papiamentu são resultado do processo de palatalização da fricativa diante do glide, isto é, [ $\theta \mathrm{j}]$. Em palavras como votashon 251 "votação" e identifikashon ${ }^{42}$, por exemplo, não se pode dizer que houve derivação sufixal do verbo votá e identifiká no papiamentu, uma vez que, em espanhol, existem as palavras votación e identificación.

\subsubsection{Falsa iotização}

A iotização se refere à passagem de qualquer fonema vocálico ou consonântico para a semivogal /j/. No primeiro momento, poder-se-ia pensar que esse processo ocorreu no papiamentu ao se adaptarem itens de L2 como caballeria do espanhol que foi nativizado como kaba[j]eria ${ }_{129}$. Contudo, de acordo com Lipiski (2007: 382), o fonema lateral palatal não aparece na maior parte da Venezuela. Além disso, segundo o estudioso, no espanhol do Caribe, é comum que o $<\mathrm{ll}>$ seja pronunciado como [j]. Logo, o que poderíamos supor como processo de iotização no papiamentu é, de fato, uma manutenção da iode do espanhol, como se pode ver nos exemplos de (35) a (38).

42 Essa palavra não pertence ao corpus. 
PAPIAMENTU

35. Desaro[j] $\mathbf{a}_{55}$

36. Desaro[j] $\mathbf{o}_{56}$

37. Kaba[j] eria 129

38. Meda[j] ista 729

\section{L2}

Desaro[j]ar

(espanhol)

Desarro[j]o

(espanhol)

Cabalj]ería

(espanhol)

Meda[j]ista

(espanhol)
Glosa

"Desenvolver"

"Desenvolvimento"

"Cavalaria"

"Medalhista"

\subsubsection{Velarização}

A velarização é a passagem de um segmento fônico não-velar para um som velar, devido à mudança do ponto de articulação principal em direção ao palato mole. No papiamentu, tal passagem foi recorrente em itens lexicais referentes ao esporte, como podemos observar em (39) e (40):
$I N G L \hat{E} S$
PAPIAMENTU
Glosa
39. Go[l]f
Go[t] $\mathbf{f}_{452}$
"Golf"
40. Goa/l]keeper
Go[t] $\operatorname{kiper}_{453}$
"Goleiro"

A pronúncia velarizada dessas palavras também pode ser vista também em outras palavras adaptadas do espanhol para o papiamentu, em que havia [1] em posição de coda, como em (41), (42) e (43):

$\begin{array}{lll}\text { ESPANHOL } & \text { PAPIAMENTU } & \text { Glosa } \\ \text { 41. Fútbo[l] } & \text { Futbò[t] }]_{637} & \text { "Futebol" } \\ \text { 42. Futsa[l] } & \text { Futsa[t] }]_{639} & \text { "Futsal" } \\ \text { 43. Go[l] } & \text { Go[t] }]_{646} & \text { "Gol" }\end{array}$

\subsubsection{Assimilação}

Segundo Andersen (1974), haveria regras de conversão que adaptam itens lexicais que violem a restrição de mesma altura para formas que não violem. Por exemplo, a palavra do 
espanhol [su'dor] tornou-se em papiamentu [so'do], nota-se que o papiamentu assimila a vogal para altura da vogal acentuada seguinte. Segundo Viaro (2011: 179), na assimilação, "sons distintos aproximam seus pontos articulatórios ou acabam por tornar-se idênticos." Na análise de palavras de adaptação recente, observa-se a aplicação dessa regra de conversão, em que a altura da vogal da sílaba acentuada é assimilada pela vogal que a antecede, como se observa em (44) e (45):

\begin{tabular}{|c|c|c|}
\hline PAPIAMENTU & L2 & Glosa \\
\hline 44. [o]utomashon 180 & $\begin{array}{l}\text { [a]utomatización } \\
\text { (espanhol) }\end{array}$ & "Automatização" \\
\hline 45. [o]utomátiko 768 & $\begin{array}{l}\text { [a]utomático } \\
(E S P / P O R)\end{array}$ & "Automático" \\
\hline
\end{tabular}

Em (44) e (45), a vogal baixa [a] assimilou a altura da vogal [o] da sílaba seguinte, tornando-se [o] também. Foi possível notar que a assimilação de altura ocorreu não só em palavras como outomashon 180 "automatização" e outomátiko 768 "automático, mas em todos os itens lexicais que tinham o prefixo auto- presente na palavra fonte, como se pode ver nos exemplos de (46) a (50).

\begin{tabular}{|c|c|c|}
\hline PAPIAMENTU & $L 2$ & Glosa \\
\hline 46. [o]utomatisá 769 & $\begin{array}{l}\text { la]utomatizar } \\
(E S P / P O R)\end{array}$ & "Automatizar" \\
\hline 47. [o]utomatisashon ${ }_{181}$ & $\begin{array}{l}\text { [a]utomatización } \\
\text { (espanhol) }\end{array}$ & "Automatização" \\
\hline 48. [o]utomatismo 770 & $\begin{array}{l}\text { [a]utomatismo } \\
(E S P / P O R)\end{array}$ & "Automatismo" \\
\hline 49. [o]utomobil ${ }_{339}$ & $\begin{array}{l}\text { [a/utomobiel } \\
\text { (holandês) }\end{array}$ & "Automóvel" \\
\hline 50. [o]utomobilista 771 & $\begin{array}{l}\text { [a]utomobilista } \\
(E S P / P O R)\end{array}$ & "Automobilista" \\
\hline
\end{tabular}

Os itens de (46) a (50) têm em comum a presença do segmento outo- que é resultado do processo de assimilação, em que a vogal [a] de auto- (L2) torna-se [o], resultando na mudança do segmento para outo- em papiamentu. Como foi dito na subseção 2.1.1, o ditongo escrito graficamente como <ou $>$ pode ser pronunciado como [ow] (d[ow] "dado" e 
t[ow] "rebocar"), ou pronunciado também como [aw]: bl[aw] "azul", Kòrs[aw] "Curaçao", r[aw] "manhã". Embora haja essas duas possibilidades, os itens aqui analisados foram todos pronunciados com o [ow]. Essa pronúncia do $<$ ou $>$ pode revelar uma tendência que favorece a vogal média fechada [o], em detrimento da vogal [a] no papiamentu. Ao analisar os itens de adaptação recente que continham o $<$ ou $>$, notou-se que o ditongo foi sempre pronunciado como [ow], não como [aw]. Talvez a pronúncia remanescente de $<$ ow $>$ como [aw], em alguns itens, seja um fóssil linguístico.

\subsubsection{Nasalização}

O processo de nasalização, sobretudo vocálica, ocorreu pontualmente nos itens lexicais dispostos de (51) a (54). Em (51) e (52), a vogal alta [u], do espanhol, passa pelo processo de nasalização e torna-se [ũ]. O exemplo em (53) mostra que, mesmo quando o item passa pelo processo de derivação (adição do sufixo -mentu), o [ũ] da palavra mantém-se nasal. Em (54), além de ter ocorrido a crase que é fusão de duas vogais iguais (contra-atacante), houve também o alçamento da vogal [a] que passa a [î].

\begin{tabular}{|c|c|c|}
\hline PAPIAMENTU & L2 & Glosa \\
\hline 51. $\mathbf{H}[\tilde{\mathbf{u}}] \mathbf{g} \mathbf{a}_{112}$ & $\begin{array}{l}J[u] g a r \\
\text { (espanhol) }\end{array}$ & "Jogar" \\
\hline $52 . \mathbf{H}[\tilde{\mathbf{u}}]$ gadó ${ }_{113}$ & $\begin{array}{l}\text { J/u]gador } \\
\text { (espanhol) }\end{array}$ & "Jogador" \\
\hline 53. $\mathbf{H}[\tilde{\mathbf{u}}]$ gamentu $\mathbf{g}_{114}$ & $\begin{array}{l}\text { J/u]gar } \\
\text { (espanhol) }\end{array}$ & "Jogo" \\
\hline 54. Kontr[ĩ $]$ kante $\mathbf{e}_{703}$ & $\begin{array}{l}\text { Contra(-)atacante } \\
(E S P / P O R)\end{array}$ & "Contra-atacante" \\
\hline
\end{tabular}

\subsubsection{Alçamento}

No momento em que vogais de uma certa abertura tornam-se mais fechadas, diz-se que tais vogais sofreram alçamento (VIARO, 2011: 166). Na análise, foram encontrados itens 
que foram submetidos a esse processo, como nos exemplos de (55) a (57). Em (55), a vogal média fechada é adaptada para [i]. Em (56) e (57), a vogal nasal [ẽ] eleva-se para [ĩ].

\section{PAPIAMENTU}

55. A[i]ropuerto 10

56. [î1]presario 653

57. [ĩ]presa 652

\section{L2}

A/e]ropuerto (espanhol) [ẽ]pres(á)rio $(E S P / P O R)$

[ẽ]presa $(E S P / P O R)$
Glosa

"Aeroporto"

"Empresário

"Empresa"

\subsubsection{Falso betacismo}

O betacismo é um fenômeno conhecido como a alternância de pronúncias entre o [b] e

[v]. Inicialmente, ao se observarem itens como buelo ${ }_{47}$ "voo" (<vuelo, espanhol), aktivo

fiho $_{14}$ "ativo fixo" (< activos fijos, "espanhol") e aviashon 26 "aviação" ( < aviación, espanhol), pode-se supor que tais palavras seriam exemplos dessa alternância de [b] e [v]. Entretanto, ao se ter acesso às pronúncias do espanhol venezuelano ${ }^{43}$, observa-se que todas as palavras citadas possuem, onde se encontra o grafema $\langle\mathrm{v}\rangle$, a fricativa bilabial sonora ([ß]). Assim,como se pode notar, o betacismo não ocorre.

\begin{tabular}{|c|c|c|}
\hline PAPIAMENTU & L2 & Glosa \\
\hline 58. A[b]ioneta 28 & $\begin{array}{l}\text { A[B]ioneta } \\
\text { (espanhol) }\end{array}$ & "avião" \\
\hline 59. [b]uèltu $\mathbf{u}_{49}$ & $\begin{array}{l}\text { [B/uelto } \\
\text { (espanhol) }\end{array}$ & "troco" \\
\hline 60. [b]uelo 47 & $\begin{array}{l}\text { [B]uelo } \\
\text { (espanhol) }\end{array}$ & "voo" \\
\hline 61. [f]]èlt $t_{285}$ & $\begin{array}{l}\text { [f]eld } \\
\text { (holandês) }\end{array}$ & "campo" \\
\hline 62. [f] riser $_{286}$ & $\begin{array}{l}\text { [f]riezer } \\
\text { (holandês) }\end{array}$ & "congelador" \\
\hline 63. [f] isitante $_{887}$ & $\begin{array}{l}{[v / \beta] \text { isitante }} \\
(E S P / P O R)\end{array}$ & "visitante" \\
\hline
\end{tabular}

${ }^{43}$ Considera-se o espanhol venezuelano, em detrimento das outras variedades do espanhol, devido à contiguidade e à constante presença de venezuelanos em Curaçao. Para as características fonológicas do espanhol da Venezuela, este estudo utilizou como base Lipski (2007) que afirma que o espanhol venezuelano pertence à zona dialetal do Caribe. 
Os itens de (58) a (60) mostram que palavras de étimo espanhol, ao serem adaptadas, sofrem uma oclusivização, pois o papiamentu substitui a fricativa [ $[\beta]$ pela oclusiva [b]. Nos exemplos (61) e (62), encontram-se palavras emprestadas do holandês, em que o $<\mathrm{v}>$ gráfico é pronunciado como [f]. A pronúncia do $\langle\mathrm{v}\rangle$ gráfico como [f] foi mantida no papiamentu nesses exemplos de étimo holandês e nos outros itens do holandês que traziam o $<\mathrm{v}>$ em sua grafia.

Nas palavras provenientes do espanhol/português, como em (63), encontrou-se a adaptação do $<\mathrm{v}\rangle$ gráfico para a fricativa surda [f]. Tendo em vista que o étimo espanhol/português pode se referir não só ao espanhol, mas também ao português, não se sabe ao certo se os itens, como visitante 887 no papiamentu, em que o $<\mathrm{v}>$ se pronuncia [f], é uma adaptação do étimo do português, no qual há a realização do [v]; ou se é uma adaptação do espanhol, em que o $<\mathrm{v}>$ é pronunciado como [ $\beta]$. Por essa razão, é difícil definir se itens de étimo espanhol/português são submetidos ao processo de ensurdecimento da fricativa $[\mathrm{v}]$, se forem provenientes do português $([v]>[\mathbf{f}])$, ou se passam por mudança no ponto de articulação da fricativa bilabial sonora para a fricativa labiodental surda $([\beta]$ $>$ [f]) se forem itens nativizados do espanhol.

\subsubsection{Aférese}

A aférese é um processo de subtração de um segmento fônico ou, às vezes, de sílabas inteiras no início dos vocábulos. Tal processo incide principalmente sobre vogais átonas, geralmente em sílabas sem coda (VIARO, 2011: 139). Ao se analisarem os itens de (64) a (67), nota-se que as palavras adaptadas para o papiamentu que sofreram aférese possuem as características descritas por Viaro (2011): são palavras iniciadas por vogais átonas e núcleo de sílabas sem coda e, nesses exemplos, sem onset.

Em (64) e (65), temos duas palavras que pertencem ao mesmo conjunto de cognatos. 
PAPIAMENTU

\section{4. [ø]probechá 205 \\ 65. [ø]probechadó 206 \\ 66. [ø]pustamentu $u_{797}$ \\ 67. [ø]kremenchá 710}

$\begin{array}{ll}\text { L2 } & \text { Glosa } \\ \text { [a]provechar (espanhol) } & \text { "Lucrar" } \\ \text { [a]provechador (espanhol) } & \text { "Aquele que lu- } \\ & \text { cra" } \\ & \text { "Apostar" } \\ {[\text { a }] \text { postar }(E S P / P O R)} & \text { "Poupar" }\end{array}$

L2

Esses dois itens sofreram apagamento da vogal [a]. Em (66), além da derivação através da adição do sufixo -mentu, houve o apagamento da vogal que inicia a palavra. Por fim, em (67), a vogal nasal [ĩ] é submetida ao processo de aférese.

\subsubsection{Síncope}

Síncope é a eliminação de segmentos fônicos ou sílabas no interior da palavra. Esse processo foi encontrado nos itens lexicais de adaptação recente. Nos exemplos de (68) a (70) e em muitos itens do espanhol, ocorreu o apagamento do glide [j] nos sufixos -miento. É provável que todas as palavras com - miento sejam convertidas para -mentu, porque este é o sufixo produtivo no papiamentu ${ }^{44}$.

\section{PAPIAMENTU}

68. Adiestramentu $u_{3}$

69. Entrenamentu $u_{93}$

70. Kayentamentu $u_{137}$

\section{ESPANHOL}

Adiestram[j]ento

Entrenam[j]ento

Calentam $[j]$ ento
Glosa

"Treinamento"

"Treinamento"

"Aquecimento"

Além da síncope nos segmentos formados por - mientu do espanhol, houve outros casos de apagamento no interior da palavra, como se pode observar nos exemplos de (71) a (73):

\footnotetext{
${ }^{44}$ Nos exemplos dessa subseção, o -mentu não pode ser considerado como sufixo no papiamentu, uma vez que foi trazido em conjunto com o item para a língua. No entanto, não se pode afirmar, com isso, que o -mentu não seja sufixo em outros itens, como dèkmentu 267 "cobertura", em que a palavra dèk $_{266}$, do holandês $d e c$, foi submetida ao processo de derivação através da adição do -mentu. Tal derivação certamente ocorreu, uma vez que não há, no holandês, uma palavra semelhante à dèkmentu ${ }_{267}$.
} 
PAPIAMENTU

71. man.ten.' shon $_{167}$

72. bò.ks.'dós 578

73. rè.'fri $\mathbf{f}_{22}$

\section{L2}

ma.n[u].ten.ción

(espanhol)

bo.xe.[a].dor

(ESP/POR)

re.f[e].rí

(espanhol)
Glosa

"Manutenção"

"boxeador"

"Árbitro"

Neste subconjunto de itens (71) a (73), nota-se que os segmentos apagados se encontram sempre antecedendo a sílaba tônica da palavra. O apagamento implicou também uma redução silábica. Em (71) e (72), palavras que, no espanhol e no espanhol/português, possuem quatro sílabas, com a síncope de um elemento, passaram a três sílabas. Em (73), a síncope fez com que a palavra trissilábica do espanhol/português se tornasse dissilábica.

\subsubsection{Apócope}

O apagamento do -r em final de palavra foi frequentemente acionado nos seguintes contextos: a) nos infinitivos verbais do espanhol/português; b) em palavras terminadas com o sufixo do espanhol/português -dor. Os dois contextos serão analisados separadamente.

O primeiro contexto favorecedor para o apócope do -r final encontra-se nos infinitivos verbais do espanhol/português. Verbos como ahorar do espanhol, arbitrar do espanhol/português, ao serem adaptados para o papiamentu, sofrem o apagamento (ahorá / arbitrá $_{552}$ ). A apócope ocorreu todas as vezes em que o verbo apresentava o $-\mathrm{r} \#$. Não houve, no corpus, ocorrência de verbos que fossem adaptados para o papiamentu com o -r realizado no final da última sílaba. Assim, tal apagamento segmental mostrou-se categórico (ver exemplos (74-78)).

A apócope do -r final foi regular apenas nos infinitivos verbais do espanhol/português talvez pelo fato de o -r final não ser marcado já nas línguas fontes e, por essa razão, 
PAPIAMENTU

74. Ahorá $[\varnothing]_{7}$

75. Barahá[ø] $]_{32}$

76. Ehersitá $[\varnothing]_{64}$

77. Arbitrá $[\varnothing]_{552}$

78. Eskalá \lceil]$_{618}$
L2

Ahora[r] (espanhol)

Baraja[r] (espanhol)

Ejercita[r] (espanhol)

Arbitra/r] (ESP/POR)

Escala[r] (ESP/POR)
Glosa

"Poupar"

"Embaralhar"

"Exercitar"

"Arbitrar"

"Escalar"

essa a presença do rótico nessa posição seja variável em itens de outros étimos, como o holandês ( spar $_{375}$ [is'pah] "poupar", do holandês spaar). Em formas verbais do holandês, por exemplo, o -r foi mantido na coda, como em $\operatorname{stir}_{381}$ ( $<$ steer, "dirigir"). A apócope do -r\# também ocorreu, de forma frequente, em palavras emprestadas com o sufixo do espanhol/português -dor, como em abridor, do espanhol, que vira abridó ${ }_{1}$. Todas as palavras emprestadas com esse afixo foram adaptadas com o apagamento (ver exemplos (79-81)). Mesmo em palavras como distribuidor 594 e embahador $_{86}$ que mantiveram o segmento - dor integralmente na grafia, notou-se que tal manutenção ocorreu apenas no âmbito gráfico, pois, nas gravações dos dados, o -r não foi pronunciado. Logo, as exceções são expressas somente na grafia, haja vista que, na pronúncia, o apagamento apresentou-se como categórico.

PAPIAMENTU

79. Emprendedó[ø] 611

80. Kontadó $[\varnothing]_{702}$

81. Finansiadó $[\varnothing]_{630}$
$E S P / P O R$

Empre(e)ndedo[r]

Contado[r]

Financiado[r]
Glosa

"Empreendedor"

"Contador"

"Financiador"

Além desses dois contextos, ocorreu o apagamento segmental em palavras terminadas com o particípio -ado, como, por exemplo, em armado, do espanhol/português, que foi natizado como armá556 "armado". Tanto no português quanto no espanhol, o particípio é uma das formas nominais que apresenta características de nome e de verbo. No papiamentu, todos os itens que sofreram tal adaptação apresentaram apenas a função de nome, 
sendo qualificadores mais precisamente (João ta stropiá / João está nocauteado). Com frequência, o -ado foi, em parte, apagado no processo de nativização (ver exemplos (82-84)) e só foi mantido em uma única palavra do corpus: impulsado ${ }^{45} 654$.

\begin{tabular}{|c|c|c|}
\hline PAPIAMENTU & $L 2$ & Glosa \\
\hline 82. Armá[ø] 556 & $\begin{array}{l}\text { Arma/ðo/dv] } \\
(E S P / P O R)\end{array}$ & "Armado" \\
\hline 83. Elektrifiká $[\varnothing]_{75}$ & $\begin{array}{l}\text { Electrifica/ðo] } \\
\text { (espanhol) }\end{array}$ & "Eletrificado" \\
\hline 84. Emití $[\varnothing]_{608}$ & $\begin{array}{l}\text { Emiti/ðo/dv] } \\
(E S P / P O R)\end{array}$ & "Transmitido" \\
\hline
\end{tabular}

\subsubsection{Redução de ditongo}

O processo de redução de ditongo também foi observado (ver exemplos (85) e (86)).

$\begin{array}{lll}\text { PAPIAMENTU } & \text { ESP/POR } & \text { Glosa } \\ \text { 85. distrib[i]dó } & \begin{array}{l}\text { distrib/wi]dor } \\ \text { distrib/i]dor }\end{array} & \text { "Distribuidor" } \\ \text { 86. hidr[ग]liko } & \text { hidr[aw]lico } & \text { "Hidráulico" }\end{array}$

Em (85), o glide [w] é apagado, fazendo com que o ditongo seja reduzido ([i] $<$ [wi]) se for considerado que, na palavra fonte, há o ditongo, no entanto é possível que o apagamento já tenha ocorrido na língua fonte. Em (86), o ditongo formado por [aw] torna-se [ə]. Como discutido na seção 2.1, segundo Kouwenberg \& Murray (1994), o papiamentu possui as seguintes possibilidades de ditongo: [aj] -ai, [aw] -ou, [cj] -ei, [ew] -eu, [iw] -iu, [oj] -oi, [ow] -ou, [øj] -ùi e [uj] -ui. Embora haja a tentativa de Kouwenberg \& Murray (1994) e Harris (1951) em descrever o sistema vocálico, nota-se que o papiamentu ainda não possui uma descrição completa de todos os ditongos possíveis na língua. Ainda que os estudiosos esbocem uma tentativa de delineamento do inventário dos ditongos, em algumas palavras,

45 Os exemplos de (79) a (81) não apresentam o elemento dó como sufixo, mas como parte integrante do item lexical em questão. No entanto o dó pode ser encontrado como sufixo em itens como stirdó 382 "motorista" que deriva do holandês steer. 
como prueba "prova", residuo "resíduo" e kontinuo "contínuo", percebe-se que há mais encontros vocálicos do que o previsto pelos autores.

\subsubsection{Epêntese}

O acréscimo de sons no interior do item lexical foi verificado durante a pesquisa. Nos casos analisados (ver exemplos (87) a (90)), os acréscimos de segmento não se devem à restrição no inventário do papiamentu. No primeiro exemplo (87), embora seja possível um cluster entre a consoante velar surda e a vibrante no papiamentu (krant, holandês), ocorre uma epêntese vocálica, desconstruindo a formação do cluster (korant ${ }_{313}$ ). A adição da vogal -o ocorre a fim de manter a estrutura de duas sílabas. Os exemplos de (88) a (90) possuem, em comum, a adaptação do prefixo aéreo/aero- através da epêntese consonantal. Em (88) e (89), houve a adição da fricativa velar surda [x] que passa a ocupar o onset silábico. Em (90), há adição do tepe [r] também na posição de ataque. Mesmo a palavra aeropuerto 4 "aeroporto" que é pronunciada sem qualquer alteração no prefixo [a'eropuehto], talvez por ser um item lexical já consolidado e de uso mais frequente, encontra-se em variação com airopuerto $_{10}$, o que mostra a instabilidade na adaptação desse afixo, em particular, no papiamentu.

\begin{tabular}{|c|c|c|}
\hline PAPIAMENTU & $L 2$ & Glosa \\
\hline 87. K[o] rant $_{313}$ & $\begin{array}{l}\text { Krant } \\
\text { (holandês) }\end{array}$ & "Jornal" \\
\hline 88. A[xe]rodinámiko 539 & $\begin{array}{l}\text { A/E/e/rodinámico } \\
(E S P / P O R)\end{array}$ & "Aerodinâmico" \\
\hline 89. A[xe]ronóutika 540 & $\begin{array}{l}\text { A/E/e/ronáutica } \\
(E S P / P O R)\end{array}$ & "Aeronáutica" \\
\hline 90. A[re]reo 536 & $\begin{array}{l}\text { A/E/e/reo } \\
(E S P / P O R)\end{array}$ & "Aéreo" \\
\hline
\end{tabular}

Nos exemplos (91) e (92), observa-se a presença de uma vogal epentética [i] no interior da palavra formada através da derivação sufixal. O [i], ao ser acrescentado, atua 
PAPIAMENTU

91. Shòp[i]mentu $u_{365}$

92. Dèk[i]mentu 267
L2

Schop (holandês)

Dec (holandês)
Glosa

"Chute"

"Cobertura"

(esporte)

como elemento que liga a base da palavra ao sufixo. Esse tipo de epêntese vocálica só foi observado nos contextos em que a base terminava com um elemento consonântico na coda, excetuando-se os casos em que a consoante se tratava de um rótico, como em ja[h]mentu 305 "caça", do holandês, jacht e sti[h]mentu 383 "direção", do holandês, steer, itens em que não houve epêntese.

\subsubsection{Metátese}

O processo de transposição de segmentos no interior da palavra foi também observado nos itens analisados, tais como nas palavras em (93) e (94).

$\begin{array}{lll}\text { PAPIAMENTU } & \text { L2 } & \text { Glosa } \\ \text { 93. eliome[tre] }]_{434} & \begin{array}{l}\text { heliome[te.l. } \\ \text { (inglês) }\end{array} & \text { "Heliômetro" } \\ \text { 94. farma[sue]tiko } 624 & \begin{array}{l}\text { farma/s/Aew]tico } \\ (E S P / P O R)\end{array} & \text { "Farmacêutico" }\end{array}$

Em (93), a metátese causou a formação de um encontro consonantal ([tre] $<$ [ter]). Em (94), o ditongo [ew], proveniente do espanhol/português, passa pela transposição silábica, tornando-se [ue]. Com a metátese, há também a eliminação do ditongo, uma vez que as vogais $[\mathrm{u}]$ e $[\mathrm{e}]$ encontram-se em sílabas distintas. 


\subsection{Ressilabificação}

O processo de ressilabificação foi bastante pontual nos contextos em que havia ditongos formados por -ia [ja] e -io [jo] nas palavras fontes. A partir da análise dos dados, observouse a transformação desses ditongos em hiato através do processo de ressilabificação, como se pode ver nos itens de (95) a (98) ${ }^{46}$. Em fuego ar.ti.fi.ci.al ${ }_{100}$ "fogos de artifício" do espanhol fuego ar.ti.fi.ci.al, nota-se que não houve a palatalização ou ressilabificação, uma vez que os segmentos -i e -a não formam ditongo na palavra fonte, encontrando-se em sílabas distintas.

$\begin{array}{lll}\text { PAPIAMENTU } & \text { L2 } & \text { Glosa } \\ \text { 95. sol.ven.si.a } 836 & \text { sol.vên.cia }(E S P / P O R) & \text { "Solvência" } \\ \text { 96. no.ti.si.a } 760 & \text { no.ti.cia }(E S P / P O R) & \text { "Notícia" } \\ \text { 97. tra.pe.si.o }{ }_{247} & \text { tra.pe.cio (espanhol) } & \text { "Trapézio" } \\ \text { 98. pre.si.den.si.a } \text { a }_{793} & \text { pre.si.dên.cia }(E S P / P O R) & \text { "Presidência" }\end{array}$

\subsubsection{A existência do / $/$ no papiamentu}

A definição do [v] como um fonema no papiamentu ainda é um fator que gera discussão nos estudos já realizados na língua. Kouwenberg \& Muysken (1995) afirmam que o [v] já é passível de ser encontrado no papiamentu, mas ainda não é um fonema e possivelmente foi incorporado há pouco tempo. Por outro lado, os mesmos autores admitem que o $<\mathrm{v}>$ encontrado na grafia pode ser lido como [b] ou [f]. Souza Neto (em preparação) afirma que a fricativa sonora deve ser considerada um fonema, uma vez que, em sua análise, foram encontrados contrastes como ['fe] /fe/ "fé" e [ve] / ve/ "letra v"; ['fi.a] /fi.a/ "emprestar" e ['vi.a] /vi.a/ "via, através, por"; [fer.'bal] /fer.bal/ 'mandado policial' e [ver.'bal] /ver.bal/ "verbal". O segmento fricativo labiodental não foi registrado sequer uma vez em todo o

${ }^{46}$ É possível encontrar ditongos formados por esses segmentos em itens do léxico do papiamentu, como konfia [kõ.'fja] "confiar", no entanto a adaptação desses ditongos nos itens de nativização recente foi categórica. 
corpus. Na realização da pesquisa de campo, observou-se que, em Curaçao, os falantes, no momento da gravação dos dados, não pronunciavam a fricativa sonora, recorrendo ao uso do [f], como em break-even 418 ['brejk] ['ejfẽ] "ponto de equilíbrio (economia)" do inglês breakeven. A ausência do $<\mathrm{v}>$ no corpus pode levar à constatação de que, se o [v] for um fonema de fato, a nativização/adaptação recente no papiamentu parece não analisar esse segmento como tal. Desse modo, espera-se que sejam realizados maiores estudos sobre essa questão para que afirmações mais definitivas possam ser feitas.

No tocante à adaptação do [v] nos itens analisados, é preciso considerar as palavras emprestadas do inglês, em detrimento das palavras de empréstimo do português, espanhol, espanhol/português ou holandês. As razões pelas quais apenas as palavras de étimo inglês funcionam como prova da adaptação do [v] de itens recentes no papiamentu residem nos seguintes pontos:

(-) Nas palavras de étimo espanhol, sabe-se que, onde há grafado o $<\mathrm{v}>$, pronunciase [ß] na referida língua (LIPSKI, 2007). Logo, ao adaptar palavras como aviación

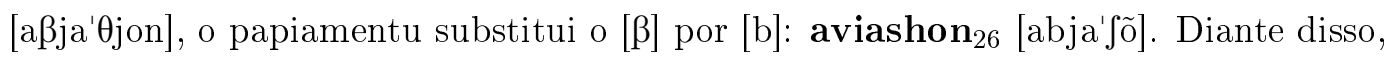
não há como comprovar que o papiamentu não pronuncia [v] nessas palavras, onde há o $<\mathrm{v}>$ gráfico, por não analisar a consoante como fonema, mas por já tomar de empréstimo palavras do espanhol, em que não se pronuncia tal segmento como fricativa labiodental sonora.

(-) Nas palavras do holandês com o $<\mathrm{v}>$ gráfico, esse $<\mathrm{v}>$ foi pronunciado como [f] nos itens analisados, como kon[f]ooi "ônibus". A pronúncia do $<\mathrm{v}>$ gráfico como [f] foi mantida no papiamentu nesse item, adaptado para kon[f] $] \mathbf{o i}_{312}$ e em todos outros itens do holandês, pertencentes ao corpus, que possuíssem o $<\mathrm{v}>$ em sua grafia. 
Desse modo, mais uma vez, não se pode dizer que houve adaptação do som do [v], pois tal fricativa não é pronunciada mesmo na palavra fonte.

(-) Nas palavras provenientes do espanhol/português, foi encontrada a adaptação do $<\mathrm{v}>$, que pode ser apenas gráfico ou não, para a fricativa labiodental surda [f]. Como o étimo espanhol/português pode se referir não só ao espanhol, mas também ao português, resta a dúvida de se, por exemplo, a palavra visitante 887 no papiamentu, em que o $<\mathrm{v}>$ se pronuncia [f], é uma adaptação do étimo do português, no qual o $<\mathrm{v}>$ é não só gráfico, como fonético; ou se é uma adaptação do espanhol, em que o $<\mathrm{v}>$ é pronunciado como [ $\beta]$. Diante desse impasse, torna-se difícil afirmar se itens do espanhol/português são submetidos ao processo de ensurdecimento da fricativa labiodental sonora, caso sejam provenientes do português $([v]>[\mathbf{f}])$, ou se passam por ensurdecimento e mudança no ponto de articulação da fricativa bilabial sonora para a fricativa labiodental surda $([\beta]>[\mathbf{f}])$ caso sejam originárias do espanhol.

(-) Nas palavras provenientes do inglês, foi observado que o [v], que não é só gráfico, mas realizado como fricativa sonora, foi sempre adaptado como outro segmento. Os itens com a consoante [v] podem ser considerados como os itens mais favoráveis à manutenção da fricativa sonora no papiamentu se, claro, esse segmento fosse analisado como fonema no processo de nativização. No entanto, em todas as palavras do inglês com o segmento [v], houve a adaptação para o [f], a exemplo de palavras como di[v]e que se nativiza dai[f] $]_{424}$ "mergulhar", scuba di/v]er que é adaptado para skubadai[f] er $_{513}$ "mergulho com botija" e ele[v]ator que se nativiza ele[f] etor $_{433}$ "elevador". A adaptação nesses dados indicariam que o [v] não é analisado como fonema pelos falantes ao menos no processo de nativização de empréstimo recente. 


\subsubsection{Vogais arredondadas}

Em relação às vogais arredondadas holandesas $(y, \varnothing)$, já havia sido levantada a hipótese, no capítulo 2 (subseção 2.1.2), de que essas vogais não fossem distintivas para os falantes nativos e não seriam, por essa razão, fonemas no papiamentu ${ }^{47}$. Segundo Souza Neto (em preparação), é possível encontrar realizações de vogais arredondadas em itens com mais de uma sílaba, como adjùst "ajustar" [a'dzøst] e ougustus [ow'xøstøs] "agosto". Nos dados analisados, a vogal $[\varnothing]$ só foi encontrada nos itens de étimo holandês, como b[ø] $\mathbf{s}_{264}(<$ bus $)$ "ônibus", l[ø]gtpòst ${ }_{319}$ (< luchtpost) "correio aéreo", outob[ø] $\mathbf{s}_{338}$ (< autobus) "ônibus" e

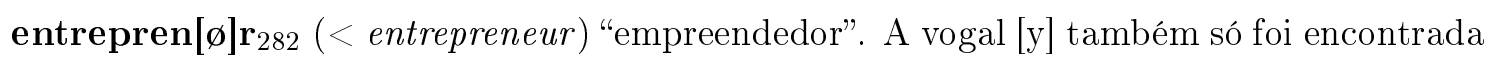
em palavras de étimo holandês, como [y]nifòrm 396 (< uniform) "uniforme", f[y]wèrk 287 $(<$ vuurwerk $)$ "fogos de artifícios" e st[y] $\mathbf{r}_{381}(<$ steer $)$ "dirigir". Assim, devido ao fato de tais vogais só terem sido realizadas em palavras emprestadas do holandês, pode-se propor que o [y] e [ø], como o [v], também não sejam analisados como fonemas pelo falante ao menos no processo de nativização de empréstimos recentes. É preciso que sejam realizados maiores estudos sobre esses aspectos do sistema vocálico da língua para que sejam feitas afirmações mais conclusivas acerca do estatuto fonêmico dessas vogais.

\subsection{Processos morfológicos}

A partir da análise de dados, observou-se a formação de palavras novas por meio da junção de uma forma nativizada recentemente com parte da morfologia do papiamentu, como os sufixos -mentu e -dó. A criação de novos itens lexicais ocorreu sob três maneiras: (a) através da adição de sufixos, (b) a partir da junção de formas apenas de uma língua fonte e (c) a partir da reunião de formas nativizadas de mais de uma língua.

${ }^{47}$ Para Kouwenberg \& Murray (1994), as vogais arredondadas se encontram severamente restritas às palavras monossilábicas do holandês e inglês. 
O papiamentu apresenta, em seu léxico, marcadores derivacionais do português e do espanhol, tais como o -mentu e o agentivo -dó. Inicialmente, pode-se supor que o mentu e o -dó não seriam afixos propriamente ditos, mas emprestados em conjunto com as palavras. Como, por exemplo, estashonamentu $u_{840}$, poder-se-ia dizer que tal palavra foi emprestada como um todo, por essa razão o -mentu não seria um afixo por si só no papiamentu. Entretanto, ao se analisarem vocábulos como dèkmentu 267 "cobertura para outro jogador" e èntermentu 281 "vacinação", nota-se que o -mentu é de fato um afixo formador de palavra (ver nos exemplos de (99) a (101)).

$\begin{array}{lll}\text { PAPIAMENTU } & \text { L2 } & \text { Glosa } \\ \text { 99. Trein[mẽtu }]_{395} & \begin{array}{l}\text { Trein } \\ \text { (holandês) }\end{array} & \text { "Treinamento" } \\ \text { 100. Seil[mẽtu }]_{510} & \begin{array}{l}\text { Sail } \\ \text { (inglês) }\end{array} & \text { "Iatismo" } \\ \text { 101. Jag[mẽtu }]_{305} & \text { Jacht (holandês) } & \text { "Caça" }\end{array}$

O sufixo -mentu esteve presente em um número significativo das palavras analisadas, entretanto, de acordo com os dados, pode-se classificar a sua presença em dois grupos distintos: (i) o -mentu que já foi tomado de empréstimo em conjunto com a palavra de L2; (ii) o -mentu como um sufixo legítimo no papiamentu. Exemplos do grupo (i) podem ser vistos em palavras como lansamentu ${ }_{721}$ "lançamento" que foi tomado de empréstimo do espanhol/português lançamiento/lançamento e adiestramentu "treinamento" proveniente do espanhol adiestramiento. O -mentu nesses vocábulos do grupo (i) não funciona como sufixo, mas como parte integrante da palavra. O mesmo não se pode afirmar de palavras do grupo (ii), como stirmentu 383 "direção" que deriva do holandês steer e kumpramentu 712 "compra" que deriva do espanhol/português comprar. Nessas palavras, nota-se que houve o processo de adição do sufixo -mentu, uma vez que nenhum desses itens ocorre nas línguas fontes. No português e no espanhol, embora seja comum o uso do 
-mento como sufixo, não existe em nenhuma das duas línguas a palavra "compramento" ou "compramiento". Assim como não há, no holandês, "steermento".

A adição do sufixo em palavras de empréstimo recente pode ser vista como um processo de formação de uma nova palavra por meio da derivação sufixal nominal, em que se criou um item novo a partir de um item já nativizado. Quanto à alta produtividade do mentu, Jacobs (2009: 62-63) afirma que o sufixo combina livremente com verbos de todos os étimos, inclusive de étimo holandês. Para o autor, combinações como a da palavra fèrfmentu "ato de pintar" (verve, do holandês "pintar" > férf "pintar") demonstram um traço claro de formação de uma nova palavra no léxico do papiamentu.

Como ocorre com o -mentu, o -dó também pode ser visto em dois grupos a partir dos dados analisados: (i) pode ter sido emprestado em conjunto com a palavra de L2; ou (ii) pode atuar como um sufixo produtivo. Palavras como adiestradó a $_{2}$ do espanhol adiestrador "treinador", arbitradó ${ }_{19}$ também do espanhol arbitrador "árbitro" e atministradó $_{566}$ do espanhol/português administrador pertencem ao grupo (i). Em relação ao grupo (ii), podemos utilizar, como exemplo, palavras como stirdó 382 "motorista" que deriva do holandês steer "dirigir" e skafdó 367 "máquina de aplainar" que deriva do holandês schaaf "avião". Percebe-se, novamente, um processo de formação de uma nova palavra através da adição do sufixo -dó. Sanchez (2005: 67), em um estudo sobre a morfologia do papiamentu, afirma que o -dó seria um exemplo de um morfema com integração limitada, uma vez que é encontrado apenas em raízes ibéricas. A análise dos dados mostra que tal afirmação estaria equivocada, pois o -dó pode ser anexado à grande maioria dos verbos em papiamentu independentemente da língua fonte desses verbos como também acredita Dijkhoff (1993).

Já o -tor, sem a sonorização, não foi encontrado como sufixo no papiamentu, mas como parte integrante do item nativizado. Os dados indicam que o -tor está presente no 
corpus não porque houve sua adição no papiamentu, mas porque tal elemento já veio integrado na palavra emprestada como em: generator 103 "gerador", do espanhol, generador, agrikultor $_{544}$ "agricultor", do espanhol/português, agricultor e lokutor 725 "locutor", do espanhol/português, locutor.

Outra forma de criação de palavras teve como base itens já nativizados no papiamentu, contudo a formação da nova palavra é baseada em itens provenientes de apenas uma língua fonte. Sob essa categoria, observaram-se dois tipos de procedimento. O primeiro tipo está ligado à criação de um novo item através de uma perífrase, por meio da qual o falante, em vez de dizer boormachine do holandês "broca", diz mashin di bora 322. Morfologicamente, percebe-se que o holandês apresenta uma estrutura de nome $(\mathrm{N} 1)+$ nome/qualificador (N2), já o papiamentu apresenta uma estrutura de nome/qualificador (N2) $+\mathbf{d i}+$ nome (N1). Assim, cria-se um novo item, invertendo a ordem (N1) + (N2) para (N2) + conectivo + (N1). O mesmo ocorre com palavras como kopieermachine que se nativiza como mashin di kopia 323 "copiadora"; nietmachine que se nativiza mashin di nit 324 "grampeador"; typemachine que é nativizada como mashin di taip 326 "máquina de escrever".

Segundo Alves (2007), um modo de integração de um item de L2 para L1 pode ocorrer através do que a autora chama de decalque. Esse processo consiste em criar um nova palavra, em L1, baseada na versão literal de um item de L2. Isso pode ser visto no português com a palavra lojas de departamentos que é um sintagma calcado no inglês department stores. Esse processo ocorreu na análise do corpus com itens como boto di motor $_{583}$ "barco a motor" que é resultado do decalque do item, do espanhol/português, barco a motor. Outro exemplo é o item sapatu di bola 817 "chuteira" que é resultado do decalque parcial do item do espanhol botas de fùtbol.

A formação de novas palavras pode também ser realizada através da junção de itens lexicais já tomados de empréstimo com um aspecto importante que os diferencia dos demais 
procedimentos: diferentes étimos atuam na formação do novo item (ver exemplos de (102)

a (107)).

\begin{tabular}{|c|c|c|c|}
\hline PAPIAMENTU & L2 & L2 & Glosa \\
\hline 102. Tiramentu di speer $_{900}$ & $\begin{array}{l}\text { Atiramento } \\
\text { (ESP/POR) }\end{array}$ & Speer (HOL) & $\begin{array}{l}\text { "Lançamento } \\
\text { dardo" }\end{array}$ \\
\hline 103. Hür di edifisio 910 & Huur (HOL) & $\begin{array}{l}\text { Edifício } \\
\text { (ESP/POR) }\end{array}$ & $\begin{array}{l}\text { "Seguro domici- } \\
\text { liar" }\end{array}$ \\
\hline 104. Sistema di huurkoop 917 & $\begin{array}{l}\text { Sistema } \\
\text { (ESP/POR) }\end{array}$ & Huurkoop(HOL) & $\begin{array}{l}\text { "Sistema de arren- } \\
\text { damento" }\end{array}$ \\
\hline 105. Karchi kòra 925 & Kaart (HOL) & Corado (PT) & "Cartão vermelho" \\
\hline 106. Bùs chikí 893 & Bus (HOL) & Chiquito (ESP) & "Microônibus" \\
\hline 107. Wega di floret 907 & Juego (ESP) & Floret (ING) & "Esgrima" \\
\hline
\end{tabular}

Nesse tipo de formação lexical, ocorre a união de duas palavras nativizadas de línguas fontes diferentes que podem ser ligadas através do uso do di como em wega di floret $_{907}$ "esgrima" derivado de juego do espanhol "jogo" e floret, do inglês, "florete" ou, na ausência do conectivo, as palavras de L2 foram adaptadas, lado a lado, como em karchi kòra925 "cartão vermelho", derivado de kaart, do holandês, "cartão" e de corado do português (exemplo (105)). O processo de criação de palavras, nessa categoria, apresentou o mesmo padrão: nome seguido pelo qualificador, sendo que o último poderia estar apenas adjacente ao nome (exemplos (105) e (106)) ou ligado a ele pelo conectivo di (exemplos de (102) a (104) e (107)).

\subsection{Variação lexical}

Outro aspecto da análise do corpus que merece atenção foi a frequente variação de vocábulos para a referência de um mesmo significado, como, por exemplo, aktivo fiho $_{14}$, do espanhol, activos fijos e vaste activa 397 , do holandês, vaste activa que se referem a mesmo termo da Economia, chamado de "ativo fixo", porém são de étimos diferentes. Em 
alguns contextos, essa variação lexical ocorreu com itens de um mesma língua, como arbitrashon $_{21}$ e arbitrahe $_{20}$ "arbitragem", adaptados do espanhol, arbitración e arbitraje, respectivamente.

Além disso, ao observar os itens que se encontram em variação no papiamentu, pode-se constatar um aspecto regular na escolha das formas variantes: das duas formas, em geral, que estão em competição, um item é do espanhol/português e o outro é de étimo holandês ou do inglês. Um exemplo disso pode ser notado no termo da Economia relativo ao que conhecemos como "capital circulante" que, em papiamentu, pode ser adaptado para uma forma do espanhol/português kapital sirkulante 675 ou para a forma com grafia idêntica à holandesa vlottende activa 401 .

Tabela 4.6: Exemplos de palavras em variação no papiamentu.

\begin{tabular}{|c|c|c|}
\hline Variante 1 & Variante 2 & Glosa \\
\hline Ahorá $_{7}<$ Ahorar, ESP & $\operatorname{Spar}_{375}<$ Spaar, HOL & Poupar \\
\hline Billar $_{42}<$ Billar, ESP & $\mathbf{P u l}_{501}<$ Pool, ING & Bilhar \\
\hline $\begin{array}{l}\text { Fuego artifisial }_{100}<\text { Fuego } \\
\text { artificial, ESP }\end{array}$ & $\begin{array}{l}\text { Füwèrk }_{287}<\text { Vuurwerk, } \\
\text { HOL }\end{array}$ & Fogos de artifícios \\
\hline $\begin{array}{l}\text { Hungamentu }_{114} \leftarrow \text { Jugar } \\
\text { ESP }\end{array}$ & Spèl $_{377}<$ Spel, HOL & Jogo \\
\hline $\begin{array}{l}\text { Impuesto }_{117}<\text { Impuesto, } \\
\text { ESP }\end{array}$ & $\begin{array}{l}\text { Belasting }_{261}<\text { Belasting, } \\
\text { HOL }\end{array}$ & Imposto \\
\hline $\begin{array}{l}\text { Invershon }_{125}<\text { Inversión, } \\
\text { ESP }\end{array}$ & $\begin{array}{l}\text { Belleging }_{262}<\text { Belegging, } \\
\text { HOL }\end{array}$ & Investimento \\
\hline Likides $_{157}<$ Liquidez, ESP & $\begin{array}{l}\text { Liquiditeit }_{318}<\text { Liquiditeit, } \\
\text { HOL }\end{array}$ & Liquidez \\
\hline Manehá $_{166}<$ Manejar, ESP & $\begin{array}{l}\text { Stir }_{381} / \text { Stür }_{385}<\text { Steer, } \\
\text { HOL }\end{array}$ & Dirigir \\
\hline $\begin{array}{l}\text { Emprendedó }_{611}<\text { Em- } \\
\text { pre(e)ndedor, ESP/POR }\end{array}$ & $\begin{array}{l}\text { Entreprenùr }_{282}<\text { Entrepre- } \\
\text { neur, HOL }\end{array}$ & Empreendedor \\
\hline
\end{tabular}

Ao analisarmos a Tabela 4.4, nota-se que as formas em variação seguem o mesmo padrão do exemplo anterior: uma das variantes (variante 1) segue um formato ibericizante, até por ser resultado de empréstimo de um item também do espanhol/português, 
e a outra forma (variante 2) corresponderia a um estrutura mais distante do formato do espanhol/português e mais próxima ao formato de palavras do inglês ou do holandês.

\subsection{Algumas observações sobre a grafia}

De acordo com Joubert (1991: 156), a padronização da grafia do papiamentu apresenta irregularidades ao lidar com palavras provenientes de empréstimo. A comissão de padronização da grafia da língua (ver seção 2.3) com frequência opta por dois caminhos: ou escolhe uma única palavra emprestada entre um conjunto de palavras emprestadas ou aceita todas como palavras da língua. Caso a segunda opção seja escolhida, a palavra fonte do empréstimo será então submetida às adaptações gráficas necessárias para que seja tomada por todos como um item lexical nativo.

Joubert sinaliza a preferência geral das comissões de grafia pelo espanhol, devido a sua grafia e "por sua maior afinidade com o papiamentu" (JOUBERT, 1991: 156). Ao analisar os dados, comprovou-se a afirmação de que o espanhol tem sido usado como referencial gráfico, como se pode ver nos exemplos ${ }^{48}$ de (108) a (114).

\begin{tabular}{|c|c|c|}
\hline PAPIAMENTU & ESPANHOL & Glosa \\
\hline 108. $<$ Bate di beisbòl $>_{36}$ & $<$ Bate de béisbol $>$ & "Bastão de beisebol" \\
\hline 109. $<$ Bateadó $>_{37}$ & $<$ Bateador $>$ & "Batedor" \\
\hline 110. $<$ Beisbòl $>_{40}$ & $<$ Béisbol $>$ & "Beisebol" \\
\hline 111. $<$ Defensor $>_{586}$ & $<$ Defensor $>$ & "Zagueiro" \\
\hline 112. $<$ Futbòl $>_{637}$ & $<$ Fútbol $>$ & "Futebol" \\
\hline 113. $<$ Futbolista $>_{101}$ & $<$ Futbolista $>$ & "Jogador de futebol" \\
\hline 114. $<$ Futsal $>_{639}$ & $<$ Futsal $>$ & "Futsal" \\
\hline
\end{tabular}

Os exemplos (115) a (117) demonstram que tais itens passaram por alterações gráficas por possuírem, em sua grafia fonte, os grafemas $<\mathbf{g}>$ e $<\mathbf{j}>$. Assim, palavras como, por exemplo, jugar "jogar" do espanhol foi adaptada graficamente para hungá ${ }_{112}$ e galope

${ }^{48}$ Os exemplos se referem apenas à grafia, não indicam que o étimo de cada palavra apresentada seja também espanhol. 
tornou-se halòp $\mathbf{p}_{108}$. No tocante à grafia das palavras emprestadas do holandês e do inglês, nota-se que elas sofreram pouca ou nenhuma alteração gráfica (exemplos (118) a (121)).

$\begin{array}{lll}\text { PAPIAMENTU } & \text { ESPANHOL } & \text { Glosa } \\ \text { 115. }<\text { Ahustá }>_{9} & <\text { Ajustar }> & \text { "Ajustar" } \\ \text { 116. }<\text { Hungadó }>_{113} & <\text { Jugador }> & \text { "Jogador" } \\ \text { 117. }<\text { Halòp }>_{108} & <\text { Galope }> & \text { "Galope" } \\ \text { 118. }<\text { Aanloopkosten }>_{254} & <\text { Aanloopkosten }>\text { HOL } & \text { "Gasto inicial" } \\ \text { 119. }<\text { Begeleiding }>_{260} & <\text { Begeleiding }>\text { HOL } & \text { "Desenvolvimento da } \\ \text { 120. }<\text { Outfielder }>_{491} & <\text { Outfielder }>\text { ING } & \text { empresa" } \\ & & \text { "Jogadores do campo } \\ \text { 121. }<\text { Burgemeester }>_{263} & <\text { Burgemeester }>\text { HOL } & \text { externo (esporte)" }\end{array}$

A preservação gráfica de itens emprestados, como em (118) a (121), pode demonstrar mais do que uma escolha por uma representação na grafia de uma língua. Quando uma palavra não é submetida a adaptações gráficas no papiamentu, isso pode indicar que tal palavra é considerada "estrangeirismo" e, por essa razão, ela não é vista pelas comissões de padronização da grafia como pertencente ao léxico nativo. Sobre isso, Joubert (1991) afirma:

Ni la comisión de estandarización, ni las proposiciones de personas individuales (Maduro, 1953, Romer, 1969), ni las comisiones de ortografia del papiamento (Daal, 1961, Maduro, 1970, Jonis 1976) han llegado a uma conclusión sobre cuando considerar extranjera una palabra y en qué caso considerarla papiamenta. En la selección de palabras por estandarizar, La Komishon Standarisashon di Papiamentu esquivó este problema, estandarizando muy pocas palabras consideradas extranjerismos ${ }^{49}[\ldots]$. (JOUBERT, 1991: 156)

49 Nem a comissão de padronização, nem as propostas de pessoas individuais (Maduro, 1953, Romer, 1969), nem as comissões de ortografia do papiamentu (Daal, 1961, Maduro, 1970, Jonis 1976) chegaram a uma conclusão sobre quando considerar uma palavra estrangeira e em que caso considerá-la do papiamento. Na seleção de palavras por padronizar, a Comissão de Padronização do Papiamentu se esquivou deste problema, padronizando muito poucas palavras consideradas estrangeirismos. (Tradução nossa) 
Embora nem sempre todas as palavras tomadas de empréstimo sejam submetidas ao processo de padronização do papiamentu por serem consideradas "estrangeirismos", não se deve pensar que itens como burgemeester $_{263}$, outfielder $_{491}$, aanloopkosten $_{254}$, por exemplo, estariam à margem do léxico nativo e usadas, por isso, com pouca frequência. Tendo em vista que as palavras de adaptação recente analisadas neste estudo foram levantadas de materiais como um dicionário bilíngue papiamentu/inglês (RATZLAFFHENRIQUEZ, 2008), manuais e livros (COSTER, 2010; PERSAUD, 1992; DANIELS, 1986) e jornais (ÈXTRA, 2011), constata-se que tais itens não só são usados de forma produtiva na língua, como também já pertecem ao vocabulário nativo. Logo, a manutenção ou mudança na grafia dos itens emprestados não deve ser vista como um indicativo da inclusão ou exclusão desses itens no léxico do papiamentu.

\subsection{Síntese}

Diante da análise dos dados, sob a pespectiva da Teoria de Restrições e Estratégias de Reparos (TCRS), proposta por Paradis (1988), foi possível alcançar o entendimento do processo de adaptação fonológica e morfológica no papiamentu. Tal teoria contudo não é a única a explicar os processos significativos na referida língua. A busca pela maior similaridade na escolha de um segmento em substituição de outro, que é, por alguma razão, ilícito no papiamentu, indica a pertinência de estudos como o de Steriade (2002), Kang (2003) e Kenstowicz (2003a). Eles afirmam que os processos de empréstimo tendem a maximizar a similaridade perceptual entre a forma adaptada e o input estrangeiro.

Além disso, foi possível notar a aplicação e funcionalidade das regras e padrões de adaptação do papiamentu, regras essas que visam adaptar itens lexicais não nativos para nativos no papiamentu. Assim, a partir da análise dos dados, confirmou-se a hipótese inicial de que os empréstimos são nativizados segundo o padrão linguístico do papiamentu. 
Também não se pode negar a influência da grafia e pronúncia do espanhol na adaptação gráfica de itens lexicais recentes. O quadro 4.5 reúne, resumidamente, os padrões encontrados a partir da análise. 
Tabela 4.7: Processos de adaptação encontrados na análise dos dados.

\begin{tabular}{|c|c|c|c|}
\hline $\begin{array}{l}\text { Processos } \quad d e \\
\text { adaptação }\end{array}$ & Contextos & Exemplos & Observações \\
\hline \multirow[t]{3}{*}{$\begin{array}{l}\text { Apagamento } \\
\text { segmental }\end{array}$} & $\begin{array}{l}\text { O }-\mathrm{r} \text { final nos } \\
\text { infinitivos ver- } \\
\text { bais do espa- } \\
\text { nhol/português é } \\
\text { apagado }\end{array}$ & $\begin{array}{l}\text { barahá }_{32} \text { "embaralhar" } \\
<\text { barajar, ESP; de- } \\
\text { toná }{ }_{593} \text { "detonar" < } \\
\text { detonar, ESP/POR }\end{array}$ & $\begin{array}{l}\text { Tal apagamento não } \\
\text { ocorre com verbos de } \\
\text { étimo holandês, em que } \\
\text { o -r permanece como } \\
\text { spar }_{375} \text { "poupar" < spar, } \\
\text { HOL; } \text { stir }_{381} \text { "dirigir" < } \\
\text { steer, HOL }\end{array}$ \\
\hline & $\begin{array}{l}\text { Palavras termina- } \\
\text { das em -dor }\end{array}$ & $\begin{array}{l}\text { eksplotadó } \\
\text { dor" }<\text { explotador, ESP; } \\
\text { finansiadó } \\
\text { fia "finan- } \\
\text { ciador" < financiador, } \\
\text { ESP/POR }\end{array}$ & $\begin{array}{l}\text { O -r foi mantido gra- } \\
\text { ficamente em palavras } \\
\text { como distribuidor } \\
\text { "distribuidor", aviador } \\
\text { "aviador", goberna- } \\
\text { dor }_{644} \text { "governador", no } \\
\text { entanto, tal segmento não } \\
\text { é pronunciado. }\end{array}$ \\
\hline & $\begin{array}{l}\text { Particípios termi- } \\
\text { nados em - ado so- } \\
\text { frem apagamento }\end{array}$ & $\begin{array}{l}\text { stropiá } \\
842<\text { estropiado } \\
\text { "nocauteado", ESP/POR; } \\
\text { armá }_{556<}<\text { armado, } \\
\text { ESP/POR }\end{array}$ & $\begin{array}{l}\text { Em todo o corpus, só } \\
\text { foi encontrada uma pa- } \\
\text { lavra que apresenta a } \\
\text { forma do partícipio do } \\
\text { espanhol/português -ado: } \\
\text { impulsado } \\
\text { (esporte)" }\end{array}$ \\
\hline Ensurdecimento & $\begin{array}{l}\text { Obstruintes sono- } \\
\text { ras em posição de } \\
\text { coda são adapta- } \\
\text { das para um seg- } \\
\text { mento surdo }\end{array}$ & $\begin{array}{l}\text { a[t]versario }{ }_{570} \quad \text { "adver- } \\
\text { sário" < a/d]versário, } \\
\text { ESP/POR; home- } \\
\text { klu[p] }]_{460} \text { "equipe que } \\
\text { começa primeiro" < home } \\
\text { clu[b], ING; le }[\mathbf{k}]_{480}< \\
\text { le }[g], \text { ING }\end{array}$ & - \\
\hline $\begin{array}{l}\text { Manutenção da } \\
\text { oclusiva }\end{array}$ & $\begin{array}{l}\text { Oclusiva velar } \\
\text { surda }[\mathrm{k}] \quad \text { em } \\
\text { posição de coda é } \\
\text { mantida }\end{array}$ & $\begin{array}{l}\text { akshon }_{12} \text { "ação" < } \\
\text { acción, ESP; elektrisi- } \\
\text { dat }_{79} \text { "eletricidade" < } \\
\text { electricidad, ESP }\end{array}$ & - \\
\hline \multirow[t]{2}{*}{-Mentu } & $\begin{array}{l}\text {-mentu como re- } \\
\text { sultado de em- } \\
\text { préstimo }\end{array}$ & $\begin{array}{lr}\text { planeamentu }_{194} & \text { "pla- } \\
\text { nejamento" }< & \text { planea- } \\
\text { miento, ESP; } & \text { desar- } \\
\text { mamentu }_{590} & \text { "desar- } \\
\text { mamento" }_{\text {mam(i)ento, ESP/POR }} & \text { desar- } \\
\text { mar }\end{array}$ & - \\
\hline & $\begin{array}{l}\text {-mentu como su- } \\
\text { fixo produtivo }\end{array}$ & $\begin{array}{l}\text { hungamentu }_{114} \text { "jogo" } \\
\leftarrow \text { jugar, ESP }+ \text {-mentu; } \\
\text { dèkmentu } \\
\text { tura" } \leftarrow \text { dec, } \text { HOL }+ \\
\text {-mentu }\end{array}$ & - \\
\hline
\end{tabular}




\begin{tabular}{|c|c|c|c|}
\hline $\begin{array}{ll}\text { Processos } & \text { de } \\
\text { adaptação } & \end{array}$ & Contextos & Exemplos & Observações \\
\hline \multirow[t]{2}{*}{-Dor/-dó } & $\begin{array}{l}\text {-dor como resul- } \\
\text { tado de emprés- } \\
\text { timo }\end{array}$ & $\begin{array}{l}\text { distribuidor }_{594} \text { "distri- } \\
\text { buidor" < distribuidor, } \\
\text { ESP/POR; eksplo- } \\
\text { tadó }_{71} \text { "detonador" < } \\
\text { explotador, ESP }\end{array}$ & - \\
\hline & $\begin{array}{l}\text {-dor como sufixo } \\
\text { produtivo }\end{array}$ & $\begin{array}{l}\text { skafdó }_{367} \text { "máquina de } \\
\text { aplainar" } \leftarrow \text { schaaf, HOL } \\
+ \text {-dó; stirdó } \\
382 \text { "moto- } \\
\text { rista" } \leftarrow \text { steer, HOL }+ \text { - } \\
\text { dó }\end{array}$ & - \\
\hline $\begin{array}{l}\text { Palatalização } \\
\text { do -ción }\end{array}$ & 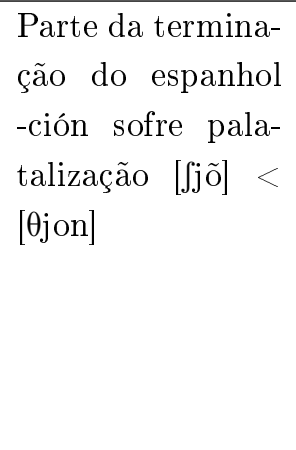 & $\begin{array}{l}\text { telekomunikashon }_{238} \\
\text { "telecomunicação" < } \\
\text { telecomunicación, ESP; } \\
\text { votashon }_{251 \quad \text { "votação" }} \\
<\text { votación, ESP }\end{array}$ & $\begin{array}{l}\text { No papiamentu, tem-se a } \\
\text { palavra importacion } 115 \\
\text { "importação", no entanto } \\
\text { o cion é apenas gráfico, } \\
\text { sendo pronunciado como } \\
\text { shon. Além disso, não } \\
\text { foi encontrado nenhuma } \\
\text { palavra que apresentasse } \\
\text { shon como sufixo. }\end{array}$ \\
\hline \multirow[t]{2}{*}{$\begin{array}{l}\text { Adaptação de } \\
\text { ditongos -ia/-io }\end{array}$} & $\begin{array}{l}\text { Palatalização da } \\
\text { consoante que an- } \\
\text { tecede o ditongo } \\
\text { em conjunto com } \\
\text { o glide -sha/o <- } \\
\text { cia/-cio }\end{array}$ & $\begin{array}{l}\text { interferensha } 665 \\
\text { terferência" } \quad<\quad \text { inter- } \\
\text { ferência } \quad \text { ESP } / \text { POR; } \\
\text { elektrishèn } 273 \quad \text { "ele- } \\
\text { tricista" < elektricien, } \\
\text { HOL }\end{array}$ & - \\
\hline & $\begin{array}{l}\text { Ressilabificação: } \\
\text { ditongo vira } \\
\text { hiato }\end{array}$ & $\begin{array}{l}\text { solvensi.a } 836 \text { "solvência" } \\
<\quad \text { solvên.cia/solven.cia, } \\
\text { ESP/POR; trapesi.o } 247 \\
\text { "trapézio" }<\text { trape.cio, } \\
\text { ESP }\end{array}$ & - \\
\hline \multirow[t]{2}{*}{$\begin{array}{l}\text { Formação de um } \\
\text { novo item }\end{array}$} & $\begin{array}{l}\text { Criação de uma } \\
\text { nova palavra a } \\
\text { partir de itens } \\
\text { emprestados de } \\
\text { uma única língua }\end{array}$ & $\begin{array}{l}\text { mashin di stènsil } \\
325 \\
\text { "mimeógrafo" } \leftarrow \text { stencil- } \\
\text { machine, HOL; mashin } \\
\text { di bora } 322 \text { "broca" } \leftarrow \text { bo- } \\
\text { ormachine, HOL }\end{array}$ & - \\
\hline & $\begin{array}{l}\text { Criação de uma } \\
\text { nova palavra a } \\
\text { partir de itens } \\
\text { emprestados de } \\
\text { mais de uma } \\
\text { língua }\end{array}$ & $\begin{array}{l}\text { tiramentu di } \text { speer }_{900} \\
\text { "lançamento de dardo" } \leftarrow \\
\text { tirar, ESP / speer, HOL; } \\
\text { mashin di kose } 895 \text { "má- } \\
\text { quina de costura" } \leftarrow \text { ma- } \\
\text { chine, HOL / coser, ESP }\end{array}$ & - \\
\hline
\end{tabular}




\begin{tabular}{|c|c|c|c|}
\hline $\begin{array}{l}\text { Processos de } \\
\text { adaptação }\end{array}$ & Contextos & Exemplos & Observações \\
\hline Vogais [ø] e [y] & $\begin{array}{l}\text { As vogais arredondadas }[\varnothing] \\
\text { e [y], presentes em palavras } \\
\text { do holandês, foram manti- } \\
\text { das no papiamentu }\end{array}$ & 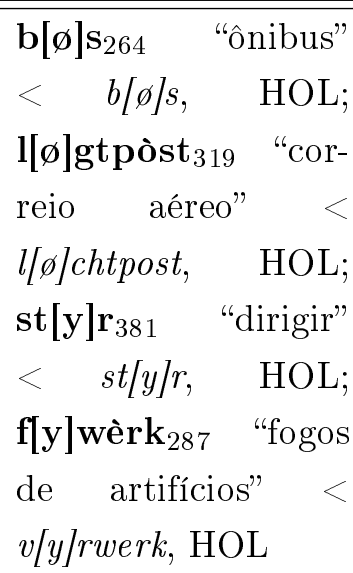 & $\begin{array}{l}\text { O }[\varnothing] \text { e }[y] \\
\text { não foram } \\
\text { encontrados } \\
\text { em outras } \\
\text { palavras em- } \\
\text { prestadas de } \\
\text { outras línguas, } \\
\text { apenas nas } \\
\text { palavras de } \\
\text { étimo holandês }\end{array}$ \\
\hline \multirow[t]{4}{*}{$\begin{array}{l}\text { Estatuto do } \\
/ \mathrm{v} /\end{array}$} & $\begin{array}{l}\text { Nas palavras de étimo es- } \\
\text { panhol, o }<\mathrm{v}>\text { é apenas } \\
\text { gráfico e realizado como }[\beta] \\
\text { que foi adaptado como [b] } \\
\text { no PP }\end{array}$ & 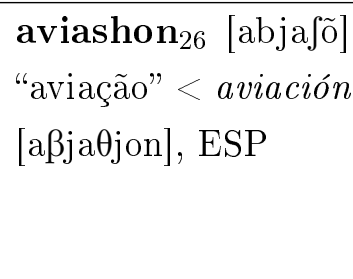 & - \\
\hline & $\begin{array}{l}\text { Nas palavras do holandês, } \\
\text { o }<\mathrm{v}>\text { foi realizado como } \\
\text { [f] e tal realização é man- } \\
\text { tida no PP }\end{array}$ & $\begin{array}{l}\text { kon[f]]oi }{ }_{312} \text { "ônibus" } \\
<\text { kon[f]ooi, HOL }\end{array}$ & - \\
\hline & $\begin{array}{l}\text { As palavras do espa- } \\
\text { nhol/português, se prove- } \\
\text { nientes do POR, passarão } \\
\text { por ensurdecimento da } \\
\text { fricativa sonora, }([\mathrm{v}]>[\mathrm{f}]) \text {; } \\
\text { se provenientes do ESP, } \\
\text { passarão por processos de } \\
\text { oclusivização da consoante } \\
\text { fricativa }([\beta]>[\mathrm{f}])\end{array}$ & $\begin{array}{l}\text { pri[f]atizar } \\
\text { "privatizar" } \\
\text { pri[B]atizar, ESP ou } \\
<\text { prilv]atizar, POR }\end{array}$ & \\
\hline & $\begin{array}{l}\text { Nas palavras do inglês, o } \\
\text { [v] foi adaptado como [f] }\end{array}$ & $\begin{array}{lr}\text { dai[f] }]_{424} & \text { "mer- } \\
\text { gulhar" }< & \text { di }[v] e ; \\
\text { skuba dai[f] } & \text { er } 513 \\
\text { "mergulho } & \text { com } \\
\text { botija" }< & \text { scuba } \\
\text { difv]er } & \end{array}$ & - \\
\hline
\end{tabular}




\section{Capítulo 5}

\section{Considerações Finais}

A nativização de palavras de origem estrangeira é, como afirmam Calabrese \& Wetzels (2009), um locus privilegiado para a observação do funcionamento do sistema linguístico da língua receptora. Ao estudar como o papiamentu adapta palavras emprestadas, é possível também analisar como a dada língua funciona sob uma abordagem linguística sincrônica. O processo de nativização está relacionado à adaptação de um item lexical de L2 em L1 por indivíduos que estão expostos à língua emprestadora, L2, e é regido por restrições fonológicas de L1, conforme discutido ao longo do presente estudo. A partir da análise de palavras de empréstimos de línguas estrangeiras dos campos de Esporte, Política, Economia, Tecnologia e Desenvolvimento no papiamentu, tal constatação foi reafirmada, uma vez que os itens analisados também foram nativizados segundo o padrão linguístico do papiamentu.

Considerando a Teoria de Restrições e Estratégias de Reparo (TCRS), proposta por Paradis (1988), confirmou-se que a informação segmental tende a ser maximamente preservada. Portanto, o apagamento não foi o recurso mais usado, ocorrendo apenas quando era necessário evitar a violação de uma restrição na L1. Também não se pode negar o papel condicionante da similaridade perceptual sobre cada adaptação de empréstimo realizada (FLEISCHHACKER, 2001, 2002; STERIADE, 2002; WALKER 2003). Notou-se que os falantes tendem a maximizar a similaridade perceptual entre a forma adaptada e o input 
estrangeiro nos processos de empréstimo. Um exemplo foi a adaptação das obstruintes sonoras em posição de coda. Como o papiamentu não admite segmentos sonoros nessa posição, ao tomar de empréstimo um item lexical que apresentava tal contexto, observouse que o falante buscou um segmento com mais traços semelhantes que, no caso, foi a contraparte surda (homeklup 460 "equipe que começa primeiro no beisebol" < home club).

Apesar de o papiamentu ser uma das línguas oficiais das ilhas de Aruba, Bonaire e Curaçao e conviver com o holandês, a proximidade com a América do Sul fez com que o léxico do papiamentu fosse influenciado pelo espanhol sul-americano. A influência do espanhol e também do português no léxico do papiamentu foi constatada, uma vez que, dos $888^{50}$ vocábulos de adaptação recente coletados pela pesquisa, 602 palavras tiveram seu étimo atribuído ao espanhol, português ou ao espanhol/português, na falta de uma definição mais precisa na escolha entre as duas línguas citadas. Em todos os campos lexicais, se analisarmos os números obtidos pelo espanhol/português juntamente com o português e o espanhol separadamente, constata-se que os últimos foram as línguas fontes das quais o papiamentu tomou mais itens lexicais de empréstimo.

Sobre os padrões de adaptação encontrados, observou-se que, em todos os verbos no infinitivo e nomes formados pelo nominalizador deverbal -dor, houve o processo de apagamento do segmento sonoro final de palavra, nesse caso o -r (barahá 32 "embaralhar" < barajar, espanhol / finansiadó 630 "financiador" < financiador, espanhol/português). Itens do espanhol/português formados pelo particípio regular -ado também passaram pelo processo de apagamento, em que o segmento -ado foi parcialmente apagado (armá 556 "armado" $<$ armado, espanhol/português).

\footnotetext{
${ }^{50}$ Foram obtidos 930 itens na formação do corpus, no entanto, 38 itens ou são palavras resultantes do processo de formação de uma nova palavra, em que o item lexical é criado através de palavras fontes de duas ou mais línguas, ou são palavras que possuem mais de um étimo possível. Desse modo, para uma análise comparativa, só foram considerados os dados que apresentaram apenas uma possibilidade quanto ao étimo (888).
} 
Durante a análise, observou-se um ensurdecimento regular em contextos em que havia obstruintes sonoras em posição de coda nos itens lexicais de L2. Diante da proibição do traço de sonoridade na coda, o papiamentu adaptou o segmento sonoro pelo seu par surdo (a[t]ministrá 564 "administrar" < ald]ministrar, espanhol/português; le[k] $]_{480}$ "etapa" < $l e[g]$, inglês).

Em relação aos sufixos, é possível encontrar itens do papiamentu que possuem o -mentu $(<$ miento/mentu $)$ e o -dó $(<$ dor $)$ como resultado de empréstimo (desarmamentu 590 "desarmamento" < desarmam(i)ento, espanhol/português; distribuidor $_{594}$ "distribuidor" < distribuidor, espanhol/português). Por outro lado, há itens que demonstram que o-mentu e -dor são sufixos produtivos no papiamentu (hungamentu u $_{14}$ "jogo" < jugar, espanhol + -mentu; stirdó 382 "motorista" < steer, holandês + -dó) .

Outro processo comum foi a palatalização categórica do segmento [өj] da terminação

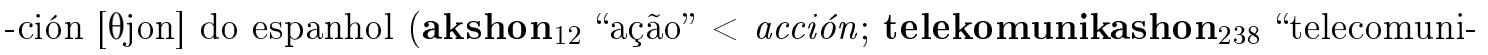
cação" < telecomunicación; votashon 251 "votação" < votación $)$.

Diante de encontros vocálicos formados por -ia/-io, o papiamentu apresentou duas formas de adaptação: a palatalização da consoante que antecede o ditongo em conjunto com o glide (interferensha 665 "interferência" < interferência, espanhol/português; elektrishèn ${ }_{273}$ "elitricista" < elektricien, holandês) ou a ressilabificação, em que o ditongo se transforma em hiato (solvensi.a836 "solvência" < solvên.cia/solven.cia, espanhol/português; trapesi.o 247 "trapézio" < trape.cio, espanhol).

O processo morfológico de criação de um novo item lexical demonstrou certa regularidade, podendo ocorrer a partir de itens tomados de empréstimo de uma única língua (mashin di stènsil 325 "mimeógrafo" < stencilmachine, holandês) ou a partir de itens provenientes de mais de uma língua (tiramentu di speer 900 "lançamento de dardo" < 
tirar, espanhol + speer, holandês; mashin di kose 895 "máquina de costura" < machine, holandês + coser, espanhol).

Além disso, a presente pesquisa constatou que, embora as vogais arredondadas $[\varnothing]$ e $[y]$, presentes em palavras do holandês, tenham sido mantidas no papiamentu, elas só foram realizadas foneticamente em itens de étimo holandês (b[ø] $\mathbf{s}_{264}$ "ônibus" $<$ b[ø]s, holandês; st[y] $\mathbf{r}_{381}$ "dirigir" < st/y]r, holandês), o que nos leva a supor que tais vogais possam não são analisadas como fonemas no processo de nativização de empréstimos recentes.

Houve também uma frequente variação de itens para a referência de um mesmo significado, como, por exemplo, aktivo fiho ${ }_{14}$ do espanhol activos fijos e vaste activa 397 do holandês vaste activa que se referem ao mesmo termo da Economia, chamado de "ativo fixo". Essa variação apresentou um aspecto regular: das duas formas, em geral, que estão em variação, um item é do espanhol/português e o outro é de étimo holandês ou inglês. Em outras palavras, a variação de itens seguiu um padrão, em que uma palavra era de étimo espanhol/português e a outra palavra foi proveniente do inglês ou do holandês.

De todo modo, pode-se afirmar que a discussão teórico-metodológica desta análise não se esgota, de maneira alguma, aqui. Assim como foi possível, ao analisar todo o corpus, verificar conjuntos de padrões de adaptação, sabe-se que no momento em que for observado um número maior de itens lexicais nativizados no papiamentu, haverá também uma ampliação do panorama linguístico, sobretudo em relação ao empréstimo e sua acomodação na língua. 


\section{Capítulo 6}

\section{Referências bibliográficas}

ADLER, Allison N. 2004. Faithfulness and perception in loanword adaptation: A case study from Hawaiian. Phonology generals paper. MIT.

ALVES, Ieda Maria. 2007. Neologismo: criação lexical. São Paulo, Ática.

ANDERSEN, Roger W. 1974. Nativization and hispanization in the Papiamentu of Curaçao, N. A.: A sociolinguistic study of variation. [Unpublished $\mathrm{PhD}$ dissertation, University of Texas at Austin.]

ARAUJO, Gabriel. 2011. Três Textos em Papiamentu Clássico. São Paulo, USP, Tese de Livre-docência.

BEST, C. T.; JONES, C. 1998. Stimulus-alternation preference procedure to test infant speech discrimination. Infant Behavior and Development, 21 (Special Issue), 295.

BEST, C. T.; WOMER, J. S.; QUEEN, H. F. 1994. Hemispheric Asymmetries in Adults' Perception of Infant Emotional Expressions. Journal of Experimental Psychology: Human Perception and Performance, 20(4), 751-765.

BRANNEN, Kathleen. 2002. The role of perception in differential substitution. Canadian Journal of Linguistics, 47, 1-46.

CALABRESE, Andrea; WETZELS, W. Leo (eds.). 2009. Loan Phonology. Amsterdam; Philadelphia: John Benjamins Pub. Co., p. 1-10.

CAMPBELL, Lyle. 1998. Historical linguistics: An introduction. Cambridge, MA: The MIT Press.

COSTER, Erwin J. 2010. FIFA Kopa Mundial 2010 i su anfitrión. Kòrsou: De Curaçaosche Courant.

DANIELS, Henky. 1986. ABC di Beisbol pa Hubentut. Curaçao: [s.n.]. 184 p.

DIJKHOFF, Marta B. 1993. Papiamentu Word Formation. Ph.D. Thesis: University of Amsterdam.

EMMANUEL, Isaac S. 1957. Precious Stones of the Jews of Curacao. Curacaon Jewry 1656-1957. New York: Bloch Publishing Company.

ÈXTRA, Korant. 2011. p. 1- 55. Korsòu. 14 out 2011.

FARACLAS, Nicholas G.; SEVERING, Ronald; WEIJER, Christa M. Rouse; ECHTELD, L. 2008. Linguistic Studies on Papiamentu. Curaçao: Fundashon pa Planifikashon di Idioma. 
FLEISCHHAKER, Heidi. 2002. Onset transfer in reduplication. Paper presented at LSA annual meeting. San Francisco: January 3-6, 2002. Retrieved September 6, 2005, from http://www.linguistics.ucla. edu/people/grads/fleischhacker/2002lsapaper.pdf

FLEISCHHACKER, Heidi. 2001. Cluster-dependent epenthesis asymmetries. In ALBRIGHT, Adam; CHO, Taehong (eds.), UCLA Working Papers in Linguistics 7, Papers in Phonology 5, pp. 71-116.

FPI. 2009. Ortografia i lista di palabra Papiamentu. Kòrsou: Fundashon pa Planifikashon di Idioma.

FREITAS, Shirley. (em preparação). Origens do papiamentu: Etimologia comparada do papiamentu e das línguas crioulas da Alta Guiné (caboverdiano e kriyol) e do Golfo da Guiné (santome, principense, angolar e fa d'ambô). Tese de doutorado.

GOILO, E. R. 1974. Hablemos papiamento. Aruba: De Wit.

GOILO, E.R. 1953. Gramática Papiamentu. Curaçao: Hollandsche Boekhandel.

GOLSTON, C.; YANG, P. 2001. White Hmong loanword phonology. In: FÉRY; C; GREEN, A.; VAN DE VIJVER, R.(eds.) Proceedings of HILP 5, 40-57. Potsdam: University of Potsdam

HANCIN-BHATT, Barbara. 1994. Segment transfer: A consequence of a dynamic system. Second Language Research, 10, 241-269.

HARRIS, Charles C. 1951. Papiamentu Phonology. Ithaca, N.Y., Cornell University Ph. D. Dissertation.

HARTOG, Johan. 1968. Curaçao, From Colonial Dependence to Autonomy. Aruba: De Wit.

HEILIGERS-HALABI, Bernadette. 1988. Guia pa empresa chiki. Kòrsou: Fundashon Empresa Chikí Kòrsou i Korpodeko. 55 p.

HISTORIA. 2007. Historia di Extra. Disponível em: <http://www.extra.an/index.php? option $=$ com_content $\&$ task=view\&id $=42 \&$ Itemid $=48>$. Acesso: 2 maio 2010.

HOCK, Hans Henrich; JOSEPH, Brian D.. 1996. Language history, language change, and language relationship: An introduction to historical and comparative linguistics. Berlin: Mouton de Gruyte.

HOLM, John. 2004. Languages in Contact. The Partial Restructuring of Vernaculars. Cambridge: Cambridge University Press.

HOLM, John. 2000. An Introduction to Pidgins and Creoles. Cambridge University Press.

HOLT, L. L. Speech Perception: Adult. In: SQUIRE, L. R (Ed.). Encyclopedia of Neuroscience, 9. Oxford: Academic Press, 2008. p. 219-226.

HOYER, W. M. 1944. Papiamentoe I su manera di skirbi. Bethencourt.

ITÔ, Junko; MESTER, Armin. 1995. Core-periphery structure of the lexicon and constraints on reranking. University of Massachusetts Occasional Papers in Linguistics 18, 181-209. Amherst.

JACOBS, Bart. 2009. The Upper Guinea origins of Papiamentu. Linguistic and historical evidence. Diachronica 26:3, 319-379. 
JOUBERT, S.M. 1991. Dikshonario Papiamentu-Hulandes - Handwoordenboek Papiaments-Nederlands. Curacao: Fundashon di Leksikografia.

KAGER, Rene. 1999. Optimality theory. Cambridge: Cambridge University Press.

KANG, Yoonjung; KENSTOWICZ, Michael; ITO, Chiyuki. Hybrid loans: a study of English loanwords transmitted to Korean via Japanese. JEAL 17, 299-316.

KANG, Yoonjung. 2003. Perceptual similarity in loanword adaptation: English postvocalic word-final stops in Korean. Phonology, 20, 219-273.

KARNER, Francis P. 1968. The sephardics of Curaçao. Assen, The Netherlands: Van Gorcum e Co.

KENSTOWICZ, Michael. 2004. Quality-sensitive stress [abridged]. In: MCCARTHY, JOHN J. (ed.). Optimality Theory in Phonology: A reader. Oxford: Blackwell, 191-201

KENSTOWICZ, Michael; SUCHATO, Atiwong. 2004. Issues in Loanword Adaptation: a Case Study from Thai. Manuscript. 2001. The role of perception in loanword phonology. In: Studies in African Linguistics, 32: 95-112.

KENSTOWICZ, Michael; SOHN, H. S. 2001. Accentual adaptation in North Kyungsang Korean. In: KENSTOWICZ, Michael (ed.) Ken Hale. A Life in Language, 239-270. Cambridge, MA: MIT Press.

KENSTOWICZ, Michael. 2003b. The role of perception in loanword phonology. A review of Les emprunts linguisiques d'origine europénne en Fon by Flavien Gbe to, Köln: Rüdiger Köppe Verlag, 2000. Studies in African Linguistics, 32, 95-112.

KENSTOWICZ, Michael. 2003a. Salience and similarity in loanword adaptation: A case study from Fijian. Unpublished manuscript, MIT. Retrieved August 11, 2005. Acesso em: 14 out 2012. Disponível em: <http://web.mit.edu/linguistics/www/ kenstowicz/kenstowicz-'03.pdf>

KENSTOWICZ, Michael. 2001. The role of perception in loanword phonology. In: Studies in African Linguistics, 32: 95-112.

KOMERSIO, Bon. 1986. Mas Trabou. Miho Kòrsou. Kòrsou: Kámara di Komersio i Industria.

KOUWENBERG, Silvia; MUYSKEN, Pieter. 1995. Papiamentu. In. ARENDS, Jacques; MUYSKEN, Pieter; SMITH, Norval. 1995. Pidgins and creoles: an introduction. Amsterdam: John Benjamins.

KOUWENBERG, Silvia; MURRAY, Eric. 1994. Papiamentu. Languages of the World/Materials 83. München: Lincom Europa.

LA CHARITÉ, Darlene; PARADIS, Carole. 2005. Category preservation and proximity versus phonetic approximation in loanword adaptation. Linguistic Inquiry, 36: 223258.

LENZ, Rodolfo. 1928. El Papiamentu: la lengua criolla de Curazao. Santiago de Chile: Balcells \& Cia.

LESSA, Orígenes. 1975. Presença do português no papiamento. Livraria editora Cátedra.

LIPSKI, John M. 2008. Spanish-Based Creoles in the Caribbean. In: KOUWENBERG, 
Silvia; SINGLER, John Victor (eds.). The Handbook of Pidgin and Creole Studies. Oxford: Wiley-Blackwell, 543-564.

LIPSKI, John M. 2007. El español de América. Madrid: Ediciones Cátedra S.A.

LOO, Inge; SMIT, Annina. 2008. The nature of L1 transfer and the influence of regional variation. Acesso em: 15 set 2012. Disponível em: <http://igiturarchive.library.uu.nl/student-theses/2008-1128-200401/masterscriptie.pdf $>$

MADURO, Antoine J.. 1971. Bon papiamentu (i un appendix interesante). Curaçao. Privately printed.

MADURO, Antoine J.. 1967. Observacion - $i$ apuntenan tocante 'El Papiamento, la lengua criolla de Curazao' Santiago de Chile - 1928 di Dr Rodolfo Lenz. Corsou: Edição do autor.

MADURO, Antoine J. 1966. Procedencia di palabranan papiamentu i otro anotacionnan. 2 vols. Curaçao. Privately printed.

MADURO, Antoine J. 1965. Papiamentu: origin i formacion. Curaçao. Privately printed.

MADURO, Antonie Johannes. 1953. Ensayo pa Yega na un Ortografia Uniforme pa nos Papiamentu. Willemstad: Edição do autor.

MARTINUS, Frank. 1996. The kiss of a slave: Papiamentu's West-African connections. Amsterdam: Universiteit van Amsterdam.

MARTINUS, Frank. 1990. Papiamentu: the Road to Emancipation. Language Reform: History and Future, vol. V ed. István Fodor \& Claude Hagège, 127-149. Hamburg: Helmut Buske Verlag.

MAURER, Philippe. 1995. L'Angolar: un créole afro-portugaise parlé à São Tomé. Hamburg: Helmut Buske Verlag.

MAURER, Philippe. 1991. El papiamentu de Curazao: un idioma verdaderamente americaño. PAPIA: Revista Brasileira de Estudos Crioulos e Similares, v. 1, n. 2.

MAURER, Philippe. 1988. Les modifications temporelles et modales du verb dans le papiamento de Curaçao (Antilles Néerlandaises). Hamburg: Helmut Buske.

MAURER, Philippe. 1986. Le papiamento de Curaçao: un cas de creolisation atypique. Etudes creoles 9/1, 97-113.

MCCARTHY, John; PRINCE, Alan. 1994. Prosodic Morphology. In: GOLDSMITH, John (ed.). A Handbook of Phonological Theory. Basil Blackwell, Oxford. Pp. $318-366$.

MCWHORTER, John. 1995. The scarcity of Spanish-based creoles explained.Language in society 24: 213-244.

MULLER, Enrique. 2007. Algun fenómeno den desaroyo di Papiamentu. Korsou: Fundashon pa Planifikshon di Idioma.

MUNTEANU, Dan. 1996. El papiamentu, lengua criolla hispánica. Madrid: Gredos.

NAVARRO, Tomás. 1951. Observaciones sobre el Papiamento. Nueva revista de filología hispánica.7: 183-189.

PARADIS, Carole; LACHARITÉ, Darlene. 1997. Preservation and minimality in loanword adaptation. Journal of Linguistics 33:379-430. 
PARADIS, Carole. 1996. The inadequacy of filters and faithfulness in Loanword Adaptation. In: Durand, Jacques \& Bernard Las. 1996. Current trends in phonology. Salford: University of Salford Publications.

PARADIS, Carole; LABEL, Caroline. 1994. Contrasts from Segmental Parameter Settings in Loanwords: Core and Periphery in Quebec French. Proceedings of the MOT Conference on Contrasts in Phonology. Toronto Working Papers in Linguistics 13: 75- 94 .

PARADIS, Carole. 1988. On constraints and repair strategies. The Linguistic Review 6, 71-97.

PARLATO-OLIVEIRA, Erika. Investigação do fenômeno de epêntese em crianças monolíngües e bilíngues: a influência da percepção na aquisição fonológica. Letras de Hoje. v. 42, n. 1. Porto Alegre, março, 2007, p. 169-178.

PEPERKAMP, S.; DUPOUX, E. 2001. Loanword adaptations: three problems for phonology. Laboratoire de Sciences Cognitives et Psycholinguistique, Paris.

PERSAUD, Ranjit. 1992. Komishon Olimpiko internashonal, kiko esei ta?Kòrsou: Fundashon Guia di Deporte. Serie: Olímpiko nr.2 ISBN 99904-9-026-1

PIETERS, Marlene. 1993. Ortografia di Papiamentu. Kòrsou: Fundashon pa Planifikashon di Idioma.

PRADO, Natália Cristine; MASSINI-CAGLIARI, Gladis. 2011. A presença de palavras de origem inglesa nos dicionários de português brasileiro: questões de identificação cultural. ReVEL, v. 9, n. 17, 2011.

PRINCE; Alan; SMOLENSKY, Paul. 1993. Optimality Theory: Constraint Interaction in Generative Grammar. Rutgers University Center for Cognitive Science Technical Report 2.

RATZLAFF-HENRIQUEZ, Betty. 2008. Dikshonario Papiamentu-Ingles/InglesPapiamentu. Bonaire: Jong Bonaire.

REIS, M. S. 2010. The perception and production of the English voiceless interdental fricative / T/ by speakers of European French and Brazilian Portuguese. Tese (Doutorado em Letras). Universidade Federal de Santa Catarina, Florianópolis.

RÖMER, Raúl G. 1991. Studies in Papiamentu Tonology. Caribean Culture Studies 5. Amsterdam/Kingston: University of the West Indies.

ROTH, Wolfgang. 1980. O empréstimo como problema de lingüística comparada. In: Alfa, Revista de Linguística, n. 24, São Paulo, UNESP, pp.157-177.

SANCHEZ, Tara S. 2005. Constraints on Structual Borrowing in a Multilingual Contact Situation. PhD dissertation, University of Pennsylvania.

SHINOHARA, S. 1997. Analyse phonologique de l'adaptation japonaise de mots étrangers. Doctoral dissertation, Université de Paris III.

SOUZA NETO, Antonio Felix. (em preparação). Fonotática do papiamentu. Tese de doutorado. USP.

STAMPE, David. 1972. On the natural history of diphthongs, Papers from the 8th regional meeting, ed. by P.M.Peranteau et al, 578-90. Chicago Linguistic Society.

STERNBERG, R. J. Cognitive Psychology. Belmont: Thompson Wadsworth, 2003 
STRANGE, W. 1995. Cross-language studies of speech perception: A historical view. In: STRANGE, W. (Ed.). Speech perception and linguistic experience: Issues in crosslanguage research. Timonium, MD: York Press, p.3-45.

SINDIKATONAN. 1985. Na kaminda pa un era nobo: Alternativa sosio-ekonómiko di sindikatonan uni di Korsou. Curaçao: SUK.

SMITH, Norval. 1999. Pernambuco to Surinam 1654-65? The Jewish slave controversy. In: HUBER, Magnus; PARKVALL, Mikael. Spreading the word: the issue of diffusion among Atlantic creoles. London: University of Westminster Press. p. 251-298.

STATISTICS, Central Bureau of. 2012. First results census 2011- Curaçao. Antilhas Holandesas. Acesso em: 14 out 2012. Disponível em: <http://www.cbs.cw/cbs/themes/ Census\%202001/Publications/Census\%202001-20121023105057.pdf>

STERIADE, Donca. 2002. The phonology of perceptibility effects: The Pmap and its consequences for constraint organization. Unpublished manuscript, UCLA. Retrieved September 6, 2005. Acesso em: 15 mai 2012. Disponível em: <http://www.linguistics.ucla.edu/people/-steriade/ papers/Pmapfor_phonology.doc $>$

TEYSSIER, Paul. 1959. La langue de Gil Vicente. Paris: Librairie C. Klincksieck.

VIARO, Mário Eduardo. 2011. Etimologia. São Paulo: Contexto, 331p.

WALKER, Rachel. 2003. Nasal and oral consonant similarity in speech errors: Exploring parallels with long-distance nasal agreement. Retrieved August 11, 2005. Acesso em: mai 2011. Disponível em: <http://www-rcf.usc.edu/ rwalker/SLIPS.pdf >

WEINREICH, Uriel. 1968. Languages in contact. The Hague: Mouton Publishers.

WEINREICH, Uriel. 1953. Languages in Contact: Findings and Problems. Publications of the Linguistics Circle of New York, no. 1.

WIJK, Henri Louis Anne van. 1958. Orígenes y evolución del Papiamentu. Neophilologus $42,169-182$

WOOD, Richard E. 1972b. The hispanization of a creole language: Papiamento. Hispania 55/4: 857-864.

WOOD, Richard. 1972a. New light on the origins of Papiamento: an Eigheenth Century Letter. Neophilologus, LVI.

WOOD, Richard E. 1970. Papiamentu: Dutch contributions. Indiana dissertation. 


\section{Apêndice A}

\section{Corpus}

Neste apêndice, encontra-se o corpus coletado. São 930 dados classificados de acordo com o campo lexical (Esporte, Economia, Tecnologia e Desenvolvimento e Política). Os dados foram distribuídos em formato de tabelas, divididos por sua etimologia provável (espanhol, holandês, inglês, espanhol/português, português e francês ${ }^{51}$ ) e organizados em ordem alfabética.

Quanto à organização das tabelas, na primeira coluna, tem-se a forma gráfica, baseada na grafia oficial de Curaçao, e sua transcrição fonética. Na segunda coluna, tem-se a possível palavra fonte do empréstimo, em itálico, seguida pela língua fonte provável do item. Nessa coluna, há três símbolos distintos para indicar o étimo provável e a mudança formal. Foi usada a seta $(\mathrm{x} \longleftarrow \mathrm{y})$ em uma direção que demonstra que $\mathrm{x}$ é derivação (morfológica) de $y^{52}$. Logo, quando houve derivação da palavra fonte, como em kumpramentu $\mathbf{u}_{712}$ "compra", por exemplo, foi utilizada a seta, pois tal item é derivado da palavra comprar do espanhol/português. O outro símbolo utilizado foi o menor que $<$, demonstrando que x provém de y. Assim, em abridó 1 , por exemplo, foi usado o símbolo $<$ antecedendo a palavra fonte abridor do espanhol, uma vez que o item do papiamentu é proveniente da

51 Só houve apenas um dado de étimo francês.

52 Retirado de Viaro (2011: 13). 
palavra do espanhol. Foi utilizado o símbolo $\Leftarrow$ demonstrando que x é afetado analogicamente por y. Assim, em mashin di bora 322 , foi usado o símbolo $\Leftarrow$ antes da palavra fonte boormachine do holandês, pois o item foi natizado através de um processo de analogia da palavra fonte. Na terceira coluna, apresenta-se o significado do item e, entre parêntese, tem-se o campo lexical ao qual o item pertence. E, por fim, na quarta coluna, a fonte da qual foi retirada a palavra.

Todas as fontes do materiais utilizados foram abreviadas. Assim, para o processo de abreviação foram utilizados as letras iniciais do(s) nome(s) do(s) autor(es) somadas ao ano de publicação. Desse modo, a referência à fonte de Coster (2010) foi abreviada como C2010; Daniels (1986) foi abreviado como D86; Hoyer (1944) foi abreviado como H44, Heiligers-Halabi (1988) foi abreviado como HH88; Ola Deportivo (1993) foi abreviado como OL93; Persaud (1992) foi abreviado como P92; Ratzlaff-Henriquez foi abreviado como RH2008; e, por fim, Sindikatonan (1985) foi abreviado como S85.

O primeiro conjunto de tabelas a ser apresentado, do número 1 ao 253, trata-se dos itens que são provenientes do espanhol. Em cada conjunto de itens provenientes do mesmo étimo, as palavras encontram-se organizadas por ordem alfabética. Do número 254 a 413, encontram-se os itens de étimo holandês. Do número 414 a 533, encontram-se os itens do inglês. Do número 534 ao 887, são apresentados os itens do espanhol/português. Do número 888 ao 891 , são apresentados os itens do português. No número 892, encontra-se um item de étimo francês. A partir do número 893, apresentam-se os itens que são provenientes de mais de um étimo. Os étimos envolvidos na formação da palavra são indicados no começo de cada conjunto de tabelas. A partir do número 931 a 957, são apresentados os itens cujo étimo é desconhecido para o presente estudo.

\section{ESPANHOL}




\begin{tabular}{|l|l|l|l|}
\hline Palavra & Etimologia provável & Significado & Fonte \\
\hline $\begin{array}{l}\text { Abridó } \\
\text { [abri'do] }\end{array}$ & $<$ Abridor & $\begin{array}{l}\text { No beisebol, espécie de jo- } \\
\text { gador que inicia o jogo } \\
\text { (abridor) (Esporte) }\end{array}$ & D86: 162 \\
\hline
\end{tabular}

2 .

\begin{tabular}{|l|l|l|l|}
\hline Palavra & Etimologia provável & Significado & Fonte \\
\hline $\begin{array}{l}\text { Adiestradó } \\
\text { 53 } \\
\text { adjestra'do }]\end{array}$ & $<$ Adiestrador, a & Treinador (Esporte) & RH2008: 3 \\
\hline
\end{tabular}

3.

\begin{tabular}{|l|l|l|l|}
\hline Palavra & Etimologia provável & Significado & Fonte \\
\hline $\begin{array}{l}\text { Adiestramentu } \\
\text { [adjestra'mẽtu }]\end{array}$ & $<$ Adiestramiento & Treinamento (Esporte) & RH2008: 3 \\
\hline
\end{tabular}

4.

\begin{tabular}{|l|l|l|l|}
\hline Palavra & Etimologia provável & Significado & Fonte \\
\hline $\begin{array}{l}\text { Aeropuerto }^{\mathbf{5 5}} \\
\text { [aero'pwehto] }\end{array}$ & $<$ Aeropuerto & $\begin{array}{l}\text { Aeroporto (Tecnologia e } \\
\text { Desenvolvimento) }\end{array}$ & RH2008: 03 \\
\hline
\end{tabular}

5.

\begin{tabular}{|l|l|l|l|}
\hline Palavra & Etimologia provável & Significado & Fonte \\
\hline $\begin{array}{l}\text { Aerospasio } \\
\text { [acros'pasio] }\end{array}$ & $<$ Aeroespacio & $\begin{array}{l}\text { Aeroespaço (Tecnologia e } \\
\text { Desenvolvimento) }\end{array}$ & RH2008: 03 \\
\hline
\end{tabular}

6.

\begin{tabular}{|l|l|l|l|}
\hline Palavra & Etimologia provável & Significado & Fonte \\
\hline $\begin{array}{l}\text { Ahedres }^{56} \\
\text { [ahe'dres }]\end{array}$ & $<$ Ajedrez & Xadrez (Esporte) & RH2008: 04 \\
\hline
\end{tabular}

7.

\begin{tabular}{|l|l|l|l|}
\hline Palavra & Etimologia provável & Significado & Fonte \\
\hline $\begin{array}{l}\text { Ahorá } \\
\text { [aho'ra }]\end{array}$ & $<$ Ahorrar & Poupar (Economia) & RH2008: 05 \\
\hline
\end{tabular}

8.

\begin{tabular}{|l|l|l|l|}
\hline Palavra & Etimologia provável & Significado & Fonte \\
\hline $\begin{array}{l}\text { Ahoro }^{\mathbf{5 8}} \\
\text { [a'horo }]\end{array}$ & $<$ Ahorro & Poupança (Economia) & RH2008: 05 \\
\hline
\end{tabular}

9.

\begin{tabular}{|l|l|l|l|}
\hline Palavra & Etimologia provável & Significado & Fonte \\
\hline $\begin{array}{l}\text { Ahustá } \\
\text { [ahus'ta }]\end{array}$ & $<$ Ajustar & Ajustar (Economia) & EX2011: 03 \\
\hline
\end{tabular}

53 Varia com entrenadó 92 e treiner $_{526}$.

54 Varia com treinmentu $u_{395}$.

55 Varia com airopuerto ${ }_{10}$.

56 Varia com chès $_{423}$.

57 Varia com kremenchá ${ }_{710}$ e spar $_{375}$.

58 Varia com spar $_{375}$ e sam $_{953}$. 
10.

\begin{tabular}{|l|l|l|l|}
\hline Palavra & Etimologia provável & Significado & Fonte \\
\hline $\begin{array}{l}\text { Airopuerto } \\
\text { 59 }\end{array}$ & $<$ Aeropuerto & $\begin{array}{l}\text { Aeroporto (Tecnologia e } \\
\text { Desenvolvimento) }\end{array}$ & RH2008: 03 \\
\hline
\end{tabular}

11.

\begin{tabular}{|l|l|l|l|}
\hline Palavra & Etimologia provável & Significado & Fonte \\
\hline $\begin{array}{l}\text { Akrobasia } \\
\text { [akro'basia }]\end{array}$ & $<$ Acrobacia & Acrobacia (Esporte) & RH2008: 5 \\
\hline
\end{tabular}

12.

\begin{tabular}{|l|l|l|l|}
\hline Palavra & Etimologia provável & Significado & Fonte \\
\hline $\begin{array}{l}\text { Akshon } \\
{\left[\text { ak' } \int \tilde{0}\right]}\end{array}$ & $<$ Acción & $\begin{array}{l}\text { Ação (bolsa de valores) } \\
\text { (Economia) }\end{array}$ & RH2008: 06 \\
& & & \\
\hline
\end{tabular}

13.

\begin{tabular}{|l|l|l|l|}
\hline Palavra & Etimologia provável & Significado & Fonte \\
\hline $\begin{array}{l}\text { Akshonista } \\
\text { [akfõ'nista }]\end{array}$ & $<$ Accionista & $\begin{array}{l}\text { Acionista (bolsa de valo- } \\
\text { res) (Economia) }\end{array}$ & RH2008: 06 \\
& & & \\
\hline
\end{tabular}

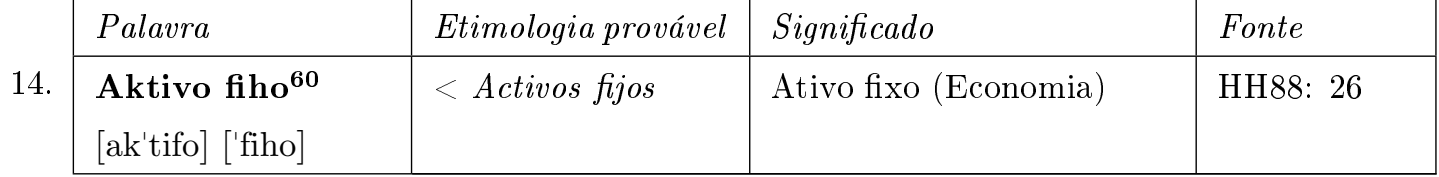

\begin{tabular}{|l|l|l|l|}
\hline Palavra & Etimologia provável & Significado & Fonte \\
\hline $\begin{array}{l}\text { Alkade } \\
\text { [ał'kade }]\end{array}$ & $<$ Alcade & Prefeito (Política) & RH2008: \\
& & & 223 \\
\hline
\end{tabular}

16.

\begin{tabular}{|l|l|l|l|}
\hline Palavra & Etimologia provável & Significado & Fonte \\
\hline $\begin{array}{l}\text { Amatúr } \\
\text { [ama'tuh] }\end{array}$ & $<$ Amateur & Amador (Esporte) & RH2008: 9 \\
\hline
\end{tabular}

\begin{tabular}{|l|l|l|l|}
\hline Palavra & Etimologia provável & Significado & Fonte \\
\hline $\begin{array}{l}\text { Amatúrismo } \\
\text { [ama'turismu }]\end{array}$ & $<$ Amateurismo & Amadorismo (Esporte) & RH2008: 9 \\
\hline
\end{tabular}

59 Varia com aeropuerto .

60 Varia com vaste activa ${ }_{397}$. 


\begin{tabular}{|l|l|l|l|}
\hline Palavra & Etimologia provável & Significado & Fonte \\
\hline $\begin{array}{l}\text { Amortisashon } \\
\text { [amohtisa'fõ] }\end{array}$ & $<$ Amortización & Amortização, redução de & HH88: 26 \\
& & $\begin{array}{l}\text { dívida por meio de paga- } \\
\text { mento parcial ou gradual } \\
\text { acertado entre as partes } \\
\text { (Economia) }\end{array}$ & \\
& & & \\
& & & \\
\hline
\end{tabular}

19.

\begin{tabular}{|l|l|l|l|}
\hline Palavra & Etimologia provável & Significado & Fonte \\
\hline $\begin{array}{l}\text { Arbitradó } \\
\text { [ahbitra'do }]\end{array}$ & $<$ Arbitrador & Árbitro (Esporte) & RH2008: 14 \\
\hline
\end{tabular}

20.

\begin{tabular}{|l|l|l|l|}
\hline Palavra & Etimologia provável & Significado & Fonte \\
\hline $\begin{array}{l}\text { Arbitrahe } \\
\text { [ahbi'trahe }]\end{array}$ & $<$ Arbitraje & Arbitragem (Esporte) & RH2008: 14 \\
\hline
\end{tabular}

21.

\begin{tabular}{|l|l|l|l|}
\hline Palavra & Etimologia provável & Significado & Fonte \\
\hline $\begin{array}{l}\text { Arbitrashon } \\
\text { [ahbitra'fõ }]\end{array}$ & $<$ Arbitración & Arbitragem (Esporte) & RH2008: 14 \\
\hline
\end{tabular}

22 .

\begin{tabular}{|l|l|l|l|}
\hline Palavra & Etimologia provável & Significado & Fonte \\
\hline $\begin{array}{l}\text { Arkeria } \\
\text { [arke'ria] }\end{array}$ & $<$ Arqueria & Arqueria (Esporte) & P92: 25 \\
\hline
\end{tabular}

23.

\begin{tabular}{|l|l|l|l|}
\hline Palavra & Etimologia provável & Significado & Fonte \\
\hline $\begin{array}{l}\text { Arkero } \\
\text { [ar'kero }]\end{array}$ & $<$ Arquero & Arqueiro (Esporte) & RH2008: 15 \\
\hline
\end{tabular}

24.

\begin{tabular}{|l|l|l|l|}
\hline Palavra & Etimologia provável & Significado & Fonte \\
\hline $\begin{array}{l}\text { Arma di Kandela } \\
{[\text { 'arma }]}\end{array}$ & $<$ Arma de candela & Arma de fogo (Tecnologia & RH2008: 15 \\
{$[$ kã'dela $]$} & & e Desenvolvimento) & \\
\hline
\end{tabular}

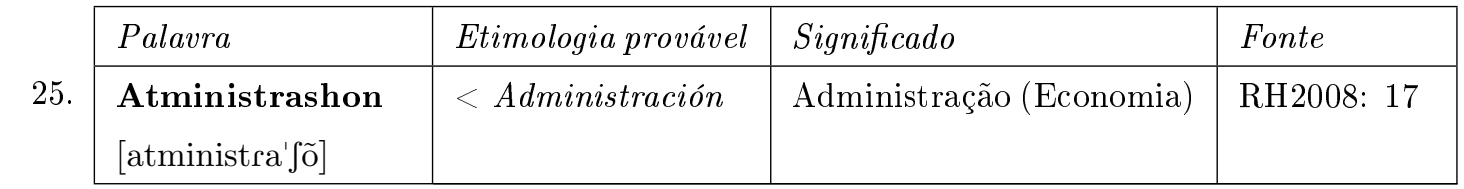

\begin{tabular}{|l|l|l|l|}
\hline 26. & Etimologia provável & Significado & Fonte \\
\cline { 2 - 5 } & $\begin{array}{l}\text { Aviashon } \\
\text { [afia'fõ }]\end{array}$ & $\begin{array}{l}\text { Aviação (Tecnologia e De- } \\
\text { senvolvimento) }\end{array}$ & RH2008: 19 \\
\hline
\end{tabular}

61 Varia com rèfri $i_{221}$.

62 Varia com arbitrashon ${ }_{21}$.

63 Varia com arbitrahe 20. 


\begin{tabular}{|l|l|l|l|}
\hline Palavra & Etimologia provável & Significado & Fonte \\
\hline $\begin{array}{l}\text { Avion } 64 \\
\text { [afi'õ }]\end{array}$ & $<$ Avión & $\begin{array}{l}\text { Avião (Tecnologia e Desen- } \\
\text { volvimento) }\end{array}$ & RH2008: 03 \\
\hline
\end{tabular}

\begin{tabular}{|l|l|l|l|}
\hline Palavra & Etimologia provável & Significado & Fonte \\
\cline { 2 - 4 } & $<$ Avioneta & $\begin{array}{l}\text { Avião (Tecnologia e Desen- } \\
\text { volvimento) }\end{array}$ & RH2008: 19 \\
\hline abio'neta $]$
\end{tabular}

\begin{tabular}{|l|l|l|l|}
\hline Palavra & Etimologia provável & Significado & Fonte \\
\hline $\begin{array}{l}\text { Balansa-di-pago } \\
\text { [ba'lãsa] [di] ['pago] }\end{array}$ & $<$ Balanza de pagos & $\begin{array}{l}\text { Balança de pagamento } \\
\text { (Economia) }\end{array}$ & S85: 18 \\
& & \\
\hline
\end{tabular}

30.

\begin{tabular}{|l|l|l|l|}
\hline Palavra & Etimologia provável & Significado & Fonte \\
\hline $\begin{array}{l}\text { Baló } \\
\text { [ba'lo] }\end{array}$ & $<$ Valor & Valor (Economia) & RH2008: 141 \\
\hline
\end{tabular}

\begin{tabular}{|c|c|c|c|}
\hline Palavra & Etimologia provável & Significado & Fonte \\
\hline $\begin{array}{l}\text { Bará di karta }{ }^{66} \\
\text { [ba'ra }][\text { di }] \text { ['kahta] }\end{array}$ & $<$ Baraja de cartas & $\begin{array}{l}\text { Baralho de cartas (Es- } \\
\text { porte) }\end{array}$ & RH2008: 23 \\
\hline
\end{tabular}

\begin{tabular}{|l|l|l|l|}
\hline 32. & Etimologia provável & Significado & Fonte \\
\hline $\begin{array}{l}\text { Barahá }^{\mathbf{6 7}} \\
\text { [bara'ha] }\end{array}$ & $<$ Barajar & Embaralhar (Esporte) & RH2008: 23 \\
\hline
\end{tabular}

\begin{tabular}{|lr|l|l|l|}
\hline Palavra & & Etimologia provável & Significado & Fonte \\
\hline $\begin{array}{l}\text { Baraha } \\
\text { karta }\end{array}$ di & $<$ Baraja de cartas & Baralho de cartas (Es- & RH2008: 23 \\
porte) & & & \\
[ba'raha $]$ & {$[\mathrm{di}]$} & & & \\
['kahta] & & & & \\
\hline
\end{tabular}

\begin{tabular}{|l|l|l|l|}
\hline Palavra & Etimologia provável & Significado & Fonte \\
\hline $\begin{array}{l}\text { Basketbòl } \\
\text { [basket'boł] }\end{array}$ & $<$ Basquetbol & Basquete (Esporte) & RH2008: 25 \\
\hline
\end{tabular}

\footnotetext{
64 Varia com avioneta $_{28}$, oroplano ${ }_{766}$ e aeroplano 542.

65 Varia com avion $_{27}$, oroplano ${ }_{766}$ e aeroplano ${ }_{542}$.

66 Varia com baraha di karta ${ }_{33}$ e bakarat $_{572}$.

67 Varia com shóbel ${ }_{954}$.

68 Varia com bará di karta $a_{31}$ e bakarat $_{572}$.
} 


\begin{tabular}{|l|l|l|l|}
\hline Palavra & Etimologia provável & Significado & Fonte \\
\hline $\begin{array}{l}\text { Bataso } \\
\text { [ba'tasu }]\end{array}$ & $<$ Batazo & $\begin{array}{l}\text { Bastão de beisebol (Es- } \\
\text { porte) }\end{array}$ & RH2008: 25 \\
\hline
\end{tabular}

36.

\begin{tabular}{|c|c|c|c|}
\hline Palavra & Etimologia provável & Significado & Fonte \\
\hline $\begin{array}{l}\text { Bate di béisbol }{ }^{70} \\
{[\text { ba'te }]} \\
{[\text { bejs'boł }]}\end{array}$ & $<$ Bate de béisbol & $\begin{array}{l}\text { Bastão de beisebol (Es- } \\
\text { porte) }\end{array}$ & RH2008: 25 \\
\hline
\end{tabular}

37.

\begin{tabular}{|l|l|l|l|}
\hline Palavra & Etimologia provável & Significado & Fonte \\
\hline $\begin{array}{l}\text { Bateadó } \\
\text { 71 } \\
\text { [batea'do] }\end{array}$ & $<$ Bateador & Batedor (Esporte) & RH2008: 25 \\
\hline
\end{tabular}

38.

\begin{tabular}{|l|l|l|l|}
\hline Palavra & Etimologia provável & Significado & Fonte \\
\hline $\begin{array}{l}\text { Batidó } \\
\text { [2 } \\
\text { [bati'do] }\end{array}$ & $<$ Batidor & Batedor (Esporte) & RH2008: 25 \\
\hline
\end{tabular}

39.

\begin{tabular}{|l|l|l|l|}
\hline Palavra & Etimologia provável & Significado & Fonte \\
\hline $\begin{array}{l}\text { Batmentòn } \\
\text { [batimẽ'tõ }]\end{array}$ & $<$ Badminton & Badminton (Esporte) & RH2008: 25 \\
\hline
\end{tabular}

40.

\begin{tabular}{|l|l|l|l|}
\hline Palavra & Etimologia provável & Significado & Fonte \\
\hline $\begin{array}{l}\text { Beisbòl } \\
\text { [bejs'boł }]\end{array}$ & $<$ Béisbol & Beisebol (Esporte) & RH2008: 25 \\
\hline
\end{tabular}

41.

\begin{tabular}{|l|l|l|l|}
\hline Palavra & Etimologia provável & Significado & Fonte \\
\hline $\begin{array}{l}\text { Biatlon } \\
\text { [bia'tlõ] }\end{array}$ & $<$ Biatlón & Biathlon (Esporte) & P92:42 \\
\hline
\end{tabular}

42.

\begin{tabular}{|l|l|l|l|}
\hline Palavra & Etimologia provável & Significado & Fonte \\
\hline $\begin{array}{l}\text { Billar } \\
\text { [bi'jah }]\end{array}$ & $<$ Billar & Bilhar (Esporte) & $\mathrm{H} 44: 58$ \\
\hline
\end{tabular}

\begin{tabular}{|l|l|l|l|}
\hline Palavra & Etimologia provável & Significado & Fonte \\
\hline Blankeo & $<$ Blanqueo & Momento em que um lan- & D86:164 \\
& & $\begin{array}{l}\text { çador não permite que o } \\
\text { time contrário pontue (bei- } \\
\end{array}$ & \\
& & sebol) (Esporte) & \\
& & & \\
\hline
\end{tabular}

69 Varia com bate di beisbòl ${ }_{36}$.

70 Varia com bataso 35 .

71 Varia com batidó 38 .

72 Varia com bateadó 37.

73 Varia com $p u l_{501}$. 


\begin{tabular}{|c|c|c|c|}
\hline Palavra & Etimologia provável & Significado & Fonte \\
\hline Bòkseo $^{74}$ & $<$ Boxeo & Pugilismo (Esporte) & RH2008: 32 \\
\hline ['bokisew] & & & \\
\hline
\end{tabular}

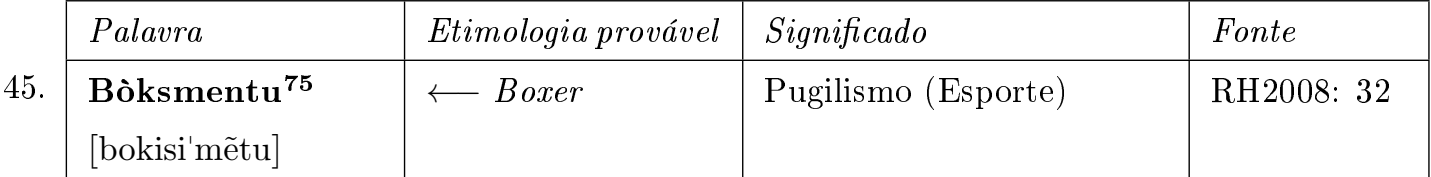

\begin{tabular}{|c|c|c|c|}
\hline Palavra & Etimologia provável & Significado & Fonte \\
\hline $\begin{array}{l}\text { Bombardeo } \\
\text { [bõbah'deo] }\end{array}$ & $<$ Bombardeo aéreo & $\begin{array}{l}\text { Bombardeio aéreo (Tecno- } \\
\text { logia e Desenvolvimento) }\end{array}$ & RH2008: 33 \\
\hline
\end{tabular}

\begin{tabular}{|l|l|l|l|}
\hline Palavra & Etimologia provável & Significado & Fonte \\
\cline { 2 - 4 } & $\begin{array}{l}\text { Buelo } \\
\text { ['bwelu] }\end{array}$ & $\begin{array}{l}\text { Voo (Tecnologia e Desen- } \\
\text { volvimento) }\end{array}$ & RH2008: 36 \\
\hline
\end{tabular}

\begin{tabular}{|l|l|l|l|}
\hline Palavra & Etimologia provável & Significado & Fonte \\
\cline { 2 - 4 } & $\longleftarrow$ Vuelto \\
['buèlta
\end{tabular}

49 .

\begin{tabular}{|l|l|l|l|}
\hline Palavra & Etimologia provável & Significado & Fonte \\
\hline $\begin{array}{l}\text { Buèltu } \\
\text { ['bwełtu }\end{array}$ & $<$ Vuelto & Troco (Economia) & RH2008: 36 \\
\hline
\end{tabular}

50.

\begin{tabular}{|l|l|l|l|}
\hline Palavra & Etimologia provável & Significado & Fonte \\
\hline $\begin{array}{l}\text { Bula } \\
\text { [bu'la }]\end{array}$ & $<$ Volar & $\begin{array}{l}\text { Explodir (Tecnologia e De- } \\
\text { senvolvimento) }\end{array}$ & RH2008: 65 \\
\hline
\end{tabular}

51.

\begin{tabular}{|l|l|l|l|}
\hline Palavra & Etimologia provável & Significado & Fonte \\
\hline $\begin{array}{l}\text { Delegashon } \\
\text { [delega'fõ] }\end{array}$ & $<$ Delegación & Delegação (Esporte) & P92: 28 \\
\hline
\end{tabular}

52.

\begin{tabular}{|l|l|l|l|}
\hline Palavra & Etimologia provável & Significado & Fonte \\
\hline $\begin{array}{l}\text { Deporte }^{\mathbf{7 8}} \\
\text { [de'pohte] }\end{array}$ & $<$ Deporte & Esporte (Esporte) & RH2008: 48 \\
\hline
\end{tabular}

\footnotetext{
74 Varia com bòksmentu 45 .

75 Varia com bòkseo 44 .

76 Varia com buèltu 49 .

77 Varia com buèlta $a_{48}$.

78 Varia com deportivo e spòrt.
} 


\begin{tabular}{|l|l|l|l|}
\hline 53. & Etimologia provável & Significado & Fonte \\
\cline { 2 - 4 } & $\begin{array}{l}\text { Deportista } \\
\text { [depoh'tista }]\end{array}$ & Esportista (Esporte) & RH2008: 48 \\
\hline
\end{tabular}

54.

\begin{tabular}{|l|l|l|l|}
\hline Palavra & Etimologia provável & Significado & Fonte \\
\hline $\begin{array}{l}\text { Deportivo }^{\mathbf{7 9}} \\
\text { [depoh'tifo] }\end{array}$ & $<$ Deportivo & $\begin{array}{l}\text { Esportivo, esporte (Es- } \\
\text { porte) }\end{array}$ & RH2008: 48 \\
& & & \\
\hline
\end{tabular}

55.

\begin{tabular}{|l|l|l|l|}
\hline Palavra & Etimologia provável & Significado & Fonte \\
\hline $\begin{array}{l}\text { Desaroyá } \\
{[\text { desaxoj'a }]}\end{array}$ & $<$ Desarrollar & Desenvolver (Economia) & EX2011: 04 \\
\hline
\end{tabular}

56.

\begin{tabular}{|l|l|l|l|}
\hline Palavra & Etimologia provável & Significado & Fonte \\
\hline $\begin{array}{l}\text { Desaroyo } \\
\text { [desa'xojo] }\end{array}$ & $<$ Desarrollo & $\begin{array}{l}\text { Desenvol-vimento (Econo- } \\
\text { mia) }\end{array}$ & EX2011: 04 \\
& & & \\
\hline
\end{tabular}

57.

\begin{tabular}{|l|l|l|l|}
\hline Palavra & Etimologia provável & Significado & Fonte \\
\hline $\begin{array}{l}\text { Desfalko } \\
\text { [des'fałko] }\end{array}$ & $<$ Desfalco & $\begin{array}{l}\text { Desfalque, desvio de fun- } \\
\text { dos (Economia) }\end{array}$ & RH2008: 50 \\
& & & \\
\hline
\end{tabular}

58.

\begin{tabular}{|l|l|l|l|}
\hline Palavra & Etimologia provável & Significado & Fonte \\
\hline $\begin{array}{l}\text { Deskuento } \\
\text { [des'kwẽto] }\end{array}$ & $<$ Descuento & Desconto (Economia) & RH2008: 50 \\
\hline
\end{tabular}

59.

\begin{tabular}{|l|l|l|l|}
\hline Palavra & Etimologia provável & Significado & Fonte \\
\hline $\begin{array}{l}\text { Detonashon } \\
\text { [detõna'fõ] }\end{array}$ & $<$ Detonación & $\begin{array}{l}\text { Detonação (Tecnologia e } \\
\text { Desenvolvimento) }\end{array}$ & RH2008: 53 \\
\hline
\end{tabular}

60.

\begin{tabular}{|l|l|l|l|}
\hline Palavra & Etimologia provável & Significado & Fonte \\
\hline $\begin{array}{l}\text { Doblete } \\
\text { [do'blete }]\end{array}$ & $<$ Doblete & $\begin{array}{l}\text { Quando a bola pode ser } \\
\text { jogada pela segunda vez } \\
\text { (beisebol) (Esporte) }\end{array}$ & D86: 165 \\
& & \\
\hline
\end{tabular}

\begin{tabular}{|l|l|l|l|}
\hline Palavra & Etimologia provável & Significado & Fonte \\
\cline { 2 - 4 } & $\begin{array}{l}\text { Ehersé }^{\mathbf{8 0}} \\
\text { [eheh'se] }\end{array}$ & $\begin{array}{l}\text { Exercitar, exercitado (Es- } \\
\text { porte) }\end{array}$ & RH2008: 165 \\
\hline
\end{tabular}

79 Varia com deporte ${ }_{52}$

80 Varia com ehersitá ${ }_{64}$. 


\begin{tabular}{|c|c|c|c|}
\hline Palavra & Etimologia provável & Significado & Fonte \\
\hline $\begin{array}{l}\text { Ehersementu }^{\mathbf{8 1}} \\
\text { [ehehse'mẽtu] }\end{array}$ & $\longleftarrow$ Ejercer & Exercício (Esporte) & RH2008: 63 \\
\hline
\end{tabular}

\begin{tabular}{|l|l|l|l|}
\hline 6alavra & Etimologia provável & Significado & Fonte \\
\cline { 2 - 4 } & $\begin{array}{l}\text { Ehersisio } \\
\text { [eheh'sisio] }\end{array}$ & Exercício (Esporte) & RH2008: 63 \\
\hline
\end{tabular}

\begin{tabular}{|c|c|c|c|}
\hline Palavra & Etimologia provável & Significado & Fonte \\
\hline $\begin{array}{l}\text { Ehersitá }^{83} \\
{[\text { ehehsi'ta] }}\end{array}$ & $<$ Ejercitar & $\begin{array}{l}\text { Exercitar, exercitado (Es- } \\
\text { porte) }\end{array}$ & RH2008: 165 \\
\hline Palavra & Etimologia provável & Significado & Fonte \\
\hline $\begin{array}{l}\text { Ehersitashon } \\
{[\text { ehehsita'fõ] }}\end{array}$ & $<$ Ejercitacion & Aptidão física (Esporte) & RH2008: 63 \\
\hline
\end{tabular}

\begin{tabular}{|l|l|l|l|}
\hline Palavra & Etimologia provável & Significado & Fonte \\
\cline { 2 - 4 } & $\begin{array}{l}\text { Ekipo } \\
\text { [e'kipo] }\end{array}$ & Time (Esporte) & RH2008: 64 \\
\hline
\end{tabular}

\begin{tabular}{|l|l|l|l|}
\hline 6alavra & Etimologia provável & Significado & Fonte \\
\hline $\begin{array}{l}\text { Ekonomisashon } \\
\text { [ekonomiza'Jõ] }\end{array}$ & $<$ Economización & Economia (Economia) & RH2008: 64 \\
\hline
\end{tabular}

\begin{tabular}{|l|l|l|l|}
\hline 6alavra & Etimologia provável & Significado & Fonte \\
\cline { 2 - 4 } & $\begin{array}{l}\text { Eksploshon } \\
{[\text { ekisplo'fõ }]}\end{array}$ & $\begin{array}{l}\text { Explosão (Tecnologia e De- } \\
\text { senvolvimento) }\end{array}$ & RH2008: 54 \\
\hline
\end{tabular}

\begin{tabular}{|c|c|c|c|}
\hline Palavra & Etimologia provável & Significado & Fonte \\
\hline $\begin{array}{l}\text { Eksplotá } \\
{[\text { ekisplo'ta }]}\end{array}$ & $<$ Explotar & $\begin{array}{l}\text { Explodir (Tecnologia e De- } \\
\text { senvolvimento) }\end{array}$ & RH2008: 52 \\
\hline
\end{tabular}

\begin{tabular}{|c|c|c|c|}
\hline Palavra & Etimologia provável & Significado & Fonte \\
\hline $\begin{array}{l}\text { Eksplotabel } \\
\text { [ekisplo'tabeł] }\end{array}$ & $\longleftarrow$ Explotar & $\begin{array}{l}\text { Explosivo (Tecnologia e } \\
\text { Desenvolvimento) }\end{array}$ & RH2008: 65 \\
\hline
\end{tabular}

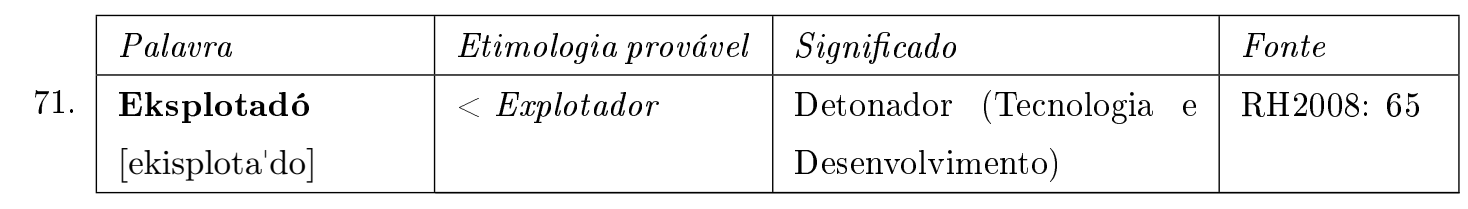

81 Varia com ehersisio $_{63}$.

82 Varia com ehersementu ${ }_{62}$.

83 Varia com ehersé 61 . 


\begin{tabular}{|c|c|c|c|}
\hline Palavra & Etimologia provável & Significado & Fonte \\
\hline $\begin{array}{l}\text { Eksplotashon } \\
\text { [ekisplota'fo] }\end{array}$ & $<$ Explotación & $\begin{array}{l}\text { Explosão (Tecnologia e De- } \\
\text { senvolvimento) }\end{array}$ & RH2008: 65 \\
\hline
\end{tabular}

\begin{tabular}{|c|c|c|c|}
\hline Palavra & Etimologia provável & Significado & Fonte \\
\hline $\begin{array}{l}\text { Electricidad } \\
\text { [elek'trisidat] }\end{array}$ & $<$ Electricidad & $\begin{array}{l}\text { Eletricidade (Tecnologia e } \\
\text { Desenvolvimento) }\end{array}$ & HH88: 44 \\
\hline
\end{tabular}

\begin{tabular}{|l|l|l|l|}
\hline Palavra & Etimologia provável & Significado & Fonte \\
\cline { 2 - 4 } & $\begin{array}{l}\text { Elekshon } \\
{[\text { elek'fõ }]}\end{array}$ & Eleição (Política) & EX2011:05 \\
\hline
\end{tabular}

\begin{tabular}{|c|c|c|c|}
\hline Palavra & Etimologia provável & Significado & Fonte \\
\hline $\begin{array}{l}\text { Elektrifiká } \\
\text { [Elektrifi'ka] }\end{array}$ & $<$ Electrificado & $\begin{array}{l}\text { Eletrificado (Tecnologia e } \\
\text { Desenvolvimento) }\end{array}$ & RH2008: 66 \\
\hline
\end{tabular}

\begin{tabular}{|l|l|l|l|}
\hline 76. & Etimologia provável & Significado & Fonte \\
\cline { 2 - 4 } & $\begin{array}{l}\text { Elektrifiká } \\
\text { [Elektrifi'ka }]\end{array}$ & $\begin{array}{l}\text { Eletrificar (Tecnologia e e } \\
\text { Desenvolvimento) }\end{array}$ & RH2008: 66 \\
\hline
\end{tabular}

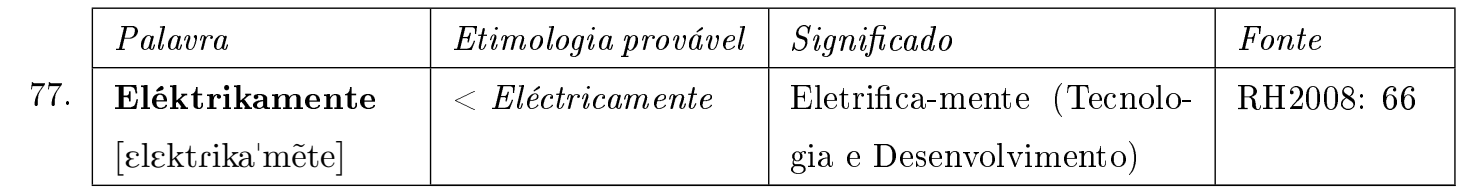

\begin{tabular}{|l|l|l|l|l|}
\hline 78. & Ealavra & Etimologia provável & Significado & Fonte \\
\cline { 2 - 4 } & $\begin{array}{l}\text { Eléktriko } \\
\text { [Elektriko }]\end{array}$ & $\begin{array}{l}\text { Elétrico (Tecnologia e De- } \\
\text { senvolvimento) }\end{array}$ & RH2008: 66 \\
\hline
\end{tabular}

\begin{tabular}{|c|c|c|c|c|}
\hline & Palavra & Etimologia provável & Significado & Fonte \\
\hline 79. & $\begin{array}{l}\text { Elektrisidat } \\
{[\text { Elcktrisi'da }]}\end{array}$ & $<$ Electricidad & $\begin{array}{l}\text { Eletricidade (Tecnologia e } \\
\text { Desenvolvimento) }\end{array}$ & RH2008: 66 \\
\hline
\end{tabular}

\begin{tabular}{|l|l|l|l|}
\hline Palavra & Etimologia provável & Significado & Fonte \\
\hline Elektroense- & $<$ Electroencefalo- & Eletroencefalograma & RH2008: 66 \\
fálogram & grama & $\begin{array}{l}\text { (Tecnologia e Desenvolvi- } \\
\text { mento) }\end{array}$ & \\
{$[$ Ele'trəẽscfalogrãm] } & & & \\
\hline
\end{tabular}

81. \begin{tabular}{|l|l|l|l|}
\hline $\begin{array}{l}\text { Palavra } \\
\text { Elektrokutá } \\
{[\text { Eletroku'ta }]}\end{array}$ & Etimologia provável & Significado & Fonte \\
\hline 82. & $<$ Electrocutado & $\begin{array}{l}\text { Eletrocutado (Tecnologia e } \\
\text { Desenvolvimento) }\end{array}$ & RH2008: 66 \\
\hline \begin{tabular}{l|l|l|l|} 
Elektrokutá \\
[Eletroku'ta $]$
\end{tabular} & Etimologia provável & Significado & Fonte \\
\hline
\end{tabular}




\begin{tabular}{|c|c|c|c|}
\hline Palavra & Etimologia provável & Significado & Fonte \\
\hline $\begin{array}{l}\text { Elektromagnético } \\
\text { [Elcktromagi'nctiko] }\end{array}$ & $<$ Electromagnético & $\begin{array}{l}\text { Eletromag-nético (Tecno- } \\
\text { logia e Desenvolvimento) }\end{array}$ & RH2008: 66 \\
\hline
\end{tabular}

\begin{tabular}{|l|l|l|l|}
\hline 84. & Etimologia provável & Significado & Fonte \\
\cline { 2 - 4 } & $\begin{array}{l}\text { Elektron } \\
{[\text { Elck'trõ }]}\end{array}$ & $\begin{array}{l}\text { Elétron (Tecnologia e De- } \\
\text { senvolvimento) }\end{array}$ & RH2008: 66 \\
\hline
\end{tabular}

\begin{tabular}{|c|c|c|c|}
\hline Palavra & Etimologia provável & Significado & Fonte \\
\hline $\begin{array}{l}\text { Elektróniko } \\
\text { [Elck'trõniko] }\end{array}$ & $<$ Electrónico & $\begin{array}{l}\text { Eletrônico (Tecnologia e } \\
\text { Desenvolvimento) }\end{array}$ & RH2008: 66 \\
\hline
\end{tabular}

\begin{tabular}{|c|c|c|c|}
\hline Palavra & Etimologia provável & Significado & Fonte \\
\hline $\begin{array}{l}\text { Embahador } \\
\text { [ẽmbaha'do] }\end{array}$ & $<$ Embajador & Embaixador (Política) & H44:12 \\
\hline
\end{tabular}

\begin{tabular}{|l|l|l|l|}
\hline 87. & Etimologia provável & Significado & Fonte \\
\hline $\begin{array}{l}\text { Empleo } \\
{[\text { é'pleo] }}\end{array}$ & $<$ Empleo & Emprego (Economia) & S85: 60 \\
\hline
\end{tabular}

\begin{tabular}{|l|l|l|l|}
\hline Palavra & Etimologia provável & Significado & Fonte \\
\hline $\begin{array}{l}\text { Empresa chikí } \\
\text { [ĩm'presa] [t]i'ki] }\end{array}$ & $<$ Empresa chiquito & $\begin{array}{l}\text { Pequena empresa (Econo- } \\
\text { mia) }\end{array}$ & RH2008: 68 \\
& & & \\
\hline
\end{tabular}

89.

\begin{tabular}{|l|l|l|l|}
\hline Palavra & Etimologia provável & Significado & Fonte \\
\hline $\begin{array}{l}\text { Empuha } \\
\text { [ẽpu'ha] }\end{array}$ & $<$ Empujar & $\begin{array}{l}\text { Tipo de jogada em beisebol } \\
\text { (Esporte) }\end{array}$ & D86: 166 \\
& & & \\
\hline
\end{tabular}

90.

\begin{tabular}{|l|l|l|l|}
\hline Palavra & Etimologia provável & Significado & Fonte \\
\hline $\begin{array}{l}\text { Entrada di } \\
\text { benta }\end{array}$ & $<$ Entrada de & Entrada de venda (Econo- & HH88: 10 \\
[ẽ'trada] [di] ['bẽta] & & mia) & \\
\hline
\end{tabular}

\begin{tabular}{|l|l|l|l|}
\hline 9alavra & Etimologia provável & Significado & Fonte \\
\cline { 2 - 4 } & $\begin{array}{l}\text { Entrená } \\
\text { [ẽntrẽ'na] }\end{array}$ & Treinar (Esporte) & RH2008: 70 \\
\hline
\end{tabular}

84 Varia com entrada anual $_{615}$. 


\begin{tabular}{|l|l|l|l|}
\hline 9alavra & Etimologia provável & Significado & Fonte \\
\cline { 2 - 4 } & $\begin{array}{l}\text { Entrenadó } \\
\mathbf{8 5} \\
\text { [ẽntrẽna'do] }\end{array}$ & Treinador (Esporte) & RH2008: 70 \\
\hline
\end{tabular}

\begin{tabular}{|c|c|c|c|}
\hline Palavra & Etimologia provável & Significado & Fonte \\
\hline $\begin{array}{l}\text { Entrenamentu } \\
\text { [ẽtrẽna'mẽtu] }\end{array}$ & $<$ Entrenamiento & Treinamento (Esporte) & RH2008: 70 \\
\hline
\end{tabular}

\begin{tabular}{|l|l|l|l|}
\hline Palavra & Etimologia provável & Significado & Fonte \\
\hline $\begin{array}{l}\text { Eror } \\
{\left[\varepsilon^{\prime} \mathrm{x} \mathrm{h}\right]}\end{array}$ & $<$ Error & Erro no jogo (Esporte) & D86: 166 \\
\hline
\end{tabular}

\begin{tabular}{|l|l|l|l|}
\hline Palavra & Etimologia provável & Significado & Fonte \\
\hline $\begin{array}{l}\text { Establesimentu } \\
\text { [establesi'mẽtu] }\end{array}$ & $<$ Establecimiento & Estabelecimento (Econo- & EX2011: 05 \\
& & mia) & \\
\hline
\end{tabular}

\begin{tabular}{|l|l|l|l|}
\hline 9alavra & Etimologia provável & Significado & Fonte \\
\cline { 2 - 4 } & $\begin{array}{l}\text { Federashon } \\
{[\text { federa'fõ] }}\end{array}$ & Federação (Esporte) & H44: 13 \\
\hline
\end{tabular}

\begin{tabular}{|l|l|l|l|}
\hline Palavra & Etimologia provável & Significado & Fonte \\
\hline Finansiero- & $<\quad$ Financiero- & Financeiro-econômico & EX2011: 04 \\
ekonómiko & econômico & (Economia) & \\
[finãsi'ero] & & & \\
[eko'nomiko] & & & \\
\hline
\end{tabular}

\begin{tabular}{|l|l|l|l|}
\hline 9alavra & Etimologia provável & Significado & Fonte \\
\cline { 2 - 4 } & $\begin{array}{l}\text { Fluktuashon } \\
\text { [flutua'fõ] }\end{array}$ & Flutuação (Economia) & EX2011: 04 \\
\hline
\end{tabular}

\begin{tabular}{|l|l|l|l|l|}
\hline Palavra & Etimologia provável & Significado & Fonte \\
\hline $\begin{array}{l}\text { Fondo } \\
\text { ['fõdo] }\end{array}$ & $<$ Fondo & Fundo (Economia) & HH88: 35 \\
\hline
\end{tabular}

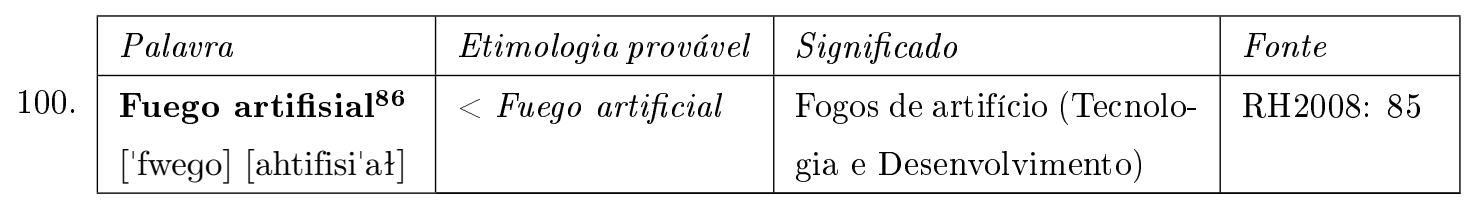

85 Varia com adiestradó 2 e treiner $_{526}$.

86 Varia com füwèrk ${ }_{287}$. 


\begin{tabular}{|l|l|l|l|}
\hline Palavra & Etimologia provável & Significado & Fonte \\
\hline $\begin{array}{l}\text { Futbolista } \\
\text { [futbo'lista }]\end{array}$ & $<$ Futbolista & $\begin{array}{l}\text { Jogador de futebol (Es- } \\
\text { porte) }\end{array}$ & RH2008: 85 \\
\hline
\end{tabular}

\begin{tabular}{|c|c|c|c|c|}
\hline & Palavra & Etimologia provável & Significado & Fonte \\
\hline 102. & $\begin{array}{l}\text { Ganga } \\
\text { ['gãga] }\end{array}$ & $<$ Ganga & $\begin{array}{l}\text { Pechincha (Tecnologia e } \\
\text { Desenvolvimento) }\end{array}$ & RH2008: 87 \\
\hline
\end{tabular}

\begin{tabular}{|c|c|c|c|c|}
\hline \multirow[b]{2}{*}{103.} & Palavra & Etimologia provável & Significado & Fonte \\
\hline & $\begin{array}{l}\text { Generator } \\
{[\text { xene'rejteh }]}\end{array}$ & $<$ Generador & $\begin{array}{l}\text { Gerador (Tecnologia e De- } \\
\text { senvolvimento) }\end{array}$ & EX2011: 11 \\
\hline \multirow[b]{2}{*}{104.} & Palavra & Etimologia provável & Significado & Fonte \\
\hline & $\begin{array}{l}\text { Gimnasia }^{88} \\
\text { [himi'nasia] }\end{array}$ & $<$ Gimnasia & Ginástica (Esporte) & RH2008: 88 \\
\hline
\end{tabular}

\begin{tabular}{|lr|l|ll|l|}
\hline Palavra & & Etimologia provável & Significado & Fonte \\
\hline Gimnasia rít- & $<$ Gimnasia rit- & Ginástica rítmica (Es- & P92: 25 \\
miko & mica \\
[himi'nasia] & ['riti- \\
miko] & & & & \\
\end{tabular}

\begin{tabular}{|l|l|l|l|}
\hline Palavra & Etimologia provável & Significado & Fonte \\
\hline $\begin{array}{l}\text { Gobièrnu } \\
\text { [go'bjehnu }]\end{array}$ & $<$ Gobierno & Governo (Política) & RH2008: \\
& & & 153 \\
\hline
\end{tabular}

\begin{tabular}{|l|l|l|l|}
\hline 107. & Etimologia provável & Significado & Fonte \\
\cline { 2 - 4 } & $\begin{array}{l}\text { Grenadero } \\
\text { [grãna'dero] }\end{array}$ & $\begin{array}{l}\text { Granadeiro (Tecnologia e } \\
\text { Desenvolvimento) }\end{array}$ & RH2008: 91 \\
\hline
\end{tabular}

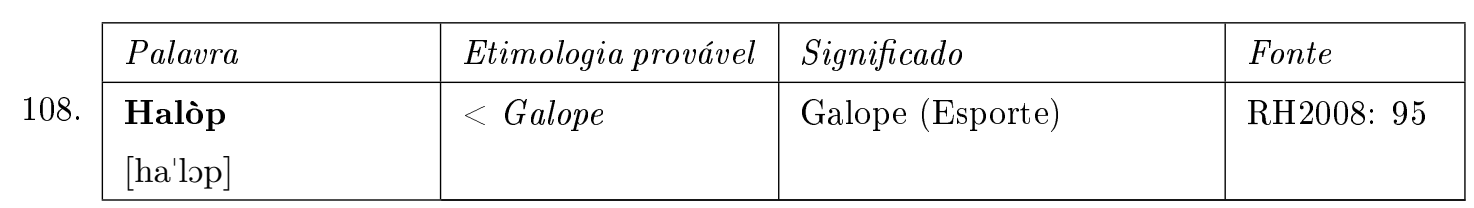

\begin{tabular}{|l|l|l|l|}
\hline Palavra & Etimologia provável & Significado & Fonte \\
\cline { 2 - 4 } & $\begin{array}{l}\text { Halopiá } \\
\text { [halopi 'a] }\end{array}$ & Galopar (Esporte) & RH2008: 95 \\
\hline
\end{tabular}

87 Varia com futbolístiko 638 .

88 Varia com Gemnastik 289 . 


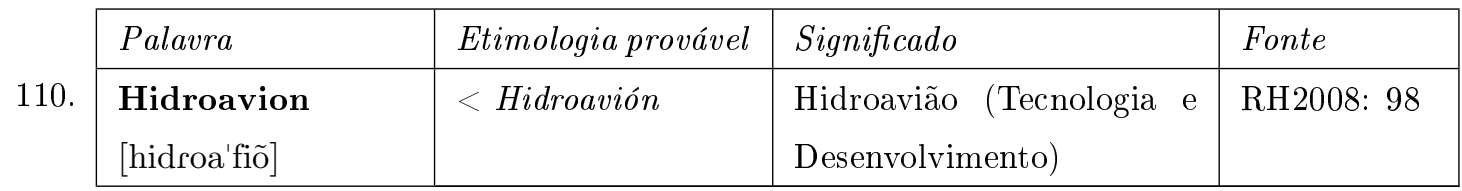

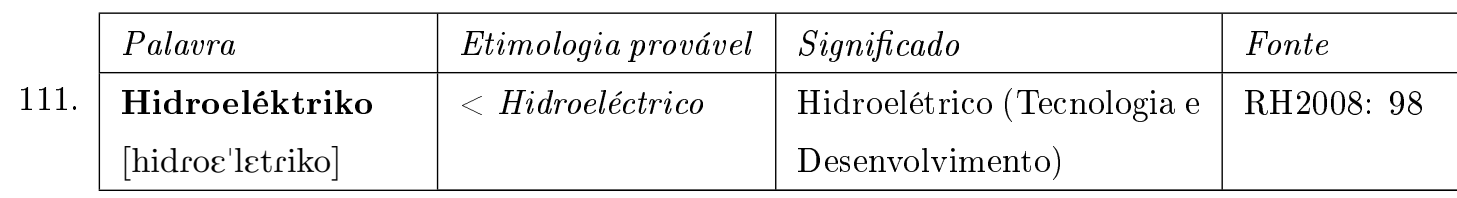

\begin{tabular}{|c|c|c|c|}
\hline Palavra & Etimologia provável & Significado & Fonte \\
\hline 112. $\begin{array}{l}\text { Hungá } \\
{[\text { hũ'ga }]}\end{array}$ & $<$ Jugar & Jogar (Esporte) & RH2008: 101 \\
\hline
\end{tabular}

\begin{tabular}{|l|l|l|l|}
\hline Palavra & Etimologia provável & Significado & Fonte \\
\hline $\begin{array}{l}\text { Hungadó } \\
{[\text { hũga'do }]}\end{array}$ & $<$ Jugador & Jogador (Esporte) & RH2008: 102 \\
\hline
\end{tabular}

\begin{tabular}{|c|c|c|c|c|}
\hline & Palavra & Etimologia provável & Significado & Fonte \\
\hline 114. & $\begin{array}{l}\text { Hungamentu } \\
\text { [hũga'mẽtu] }\end{array}$ & $\longleftarrow$ Jugar & Jogo (Esporte) & RH2008: 102 \\
\hline
\end{tabular}

\begin{tabular}{|c|c|c|c|c|}
\hline & Palavra & Etimologia provável & Significado & Fonte \\
\hline 115. & 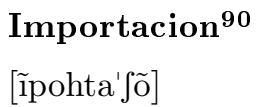 & $<$ Importación & Importação (Economia) & HH88: 59 \\
\hline
\end{tabular}

\begin{tabular}{|l|l|l|l|}
\hline Palavra & Etimologia provável & Significado & Fonte \\
\hline $\begin{array}{l}\text { Importashon 91 } \\
{[\text { ĩpohta'fõ] }}\end{array}$ & $<$ Importación & Importação (Economia) & EX2011: 05 \\
\hline
\end{tabular}

\begin{tabular}{|l|l|l|l|}
\hline 117. & Etimologia provável & Significado & Fonte \\
\hline $\begin{array}{l}\text { Impuesto } \\
\text { [i'pwesto] }\end{array}$ & $<$ Impuesto & Imposto (Economia) & RH2008: 106 \\
\hline
\end{tabular}

\begin{tabular}{|l|l|l|l|}
\hline Palavra & Etimologia provável & Significado & Fonte \\
\hline $\begin{array}{l}\text { Industrialisashon } \\
\text { [̃̃dustrializa'fõ] }\end{array}$ & $<$ Industrialización & $\begin{array}{l}\text { Industrialização (Econo- } \\
\text { mia) }\end{array}$ & RH2008: 107 \\
& & & \\
\hline
\end{tabular}

\footnotetext{
${ }^{89}$ Varia com spèl $_{377}$.

90 Varia com importashon ${ }_{116}$.

91 Varia com importacion 115 .

92 Varia com belasting ${ }_{261}$ e presupuesto $_{203}$.
} 


\begin{tabular}{|c|c|c|c|c|}
\hline & Palavra & Etimologia provável & Significado & Fonte \\
\hline 119. & $\begin{array}{l}\text { Inflashon } \\
\text { [îfla'fõ] }\end{array}$ & $<$ Inflación & Inflação (Economia) & RH2008: 108 \\
\hline
\end{tabular}

120.

\begin{tabular}{|l|l|l|l|}
\hline Palavra & Etimologia provável & Significado & Fonte \\
\hline $\begin{array}{l}\text { Infrakshon } \\
\text { [ĩfrak'fõ] }\end{array}$ & $<$ Infracción & $\begin{array}{l}\text { Infração, falta cometida no } \\
\text { jogo (Esporte) }\end{array}$ & H44:29 \\
\hline
\end{tabular}

121.

\begin{tabular}{|l|l|l|l|}
\hline Palavra & Etimologia provável & Significado & Fonte \\
\hline $\begin{array}{l}\text { Infrastruktura } \\
\text { [̃fraistruk'tura] }\end{array}$ & $<$ Infraestructura & $\begin{array}{l}\text { Infra-estrutura (Econo- } \\
\text { mia) }\end{array}$ & EX2011: 10 \\
\hline
\end{tabular}

122.

\begin{tabular}{|l|l|l|l|}
\hline Palavra & Etimologia provável & Significado & Fonte \\
\hline $\begin{array}{l}\text { Infrastruktural } \\
\text { [̃fraistruk'turał }]\end{array}$ & $<$ Infraestructural & $\begin{array}{l}\text { Infra-estrutural (Econo- } \\
\text { mia) }\end{array}$ & EX2011: 10 \\
\hline
\end{tabular}

123.

\begin{tabular}{|l|l|l|l|}
\hline Palavra & Etimologia provável & Significado & Fonte \\
\hline $\begin{array}{l}\text { Ingeniero } \\
\text { [inh'njero] }\end{array}$ & $<$ Ingeniero & $\begin{array}{l}\text { Engenheiro (Tecnologia e } \\
\text { Desenvolvimento) }\end{array}$ & RH2008: 108 \\
\hline
\end{tabular}

124

\begin{tabular}{|l|l|l|l|}
\hline Palavra & Etimologia provável & Significado & Fonte \\
\hline $\begin{array}{l}\text { Ingreso } \\
\text { [ígreso] }\end{array}$ & $\begin{array}{l}\text { Receita pública (Econo- } \\
\text { mia) }\end{array}$ & RH2008: 108 \\
\hline
\end{tabular}

125.

\begin{tabular}{|l|l|l|l|}
\hline Palavra & Etimologia provável & Significado & Fonte \\
\hline $\begin{array}{l}\text { Invershon } \\
\text { [ĩfeh'fõ }]\end{array}$ & $<$ Inversión & Investimento (Economia) & HH88: 35 \\
\hline
\end{tabular}

126.

\begin{tabular}{|l|l|l|l|}
\hline Palavra & Etimologia provável & Significado & Fonte \\
\hline $\begin{array}{l}\text { Invershon finan- } \\
\text { siero }\end{array} \mathbf{9 4}$ & $<$ Inversión- & Investimento (Economia) & S85: 16 \\
[îfeh'Jõ] [finã'sjero] & financiero & & \\
\hline
\end{tabular}

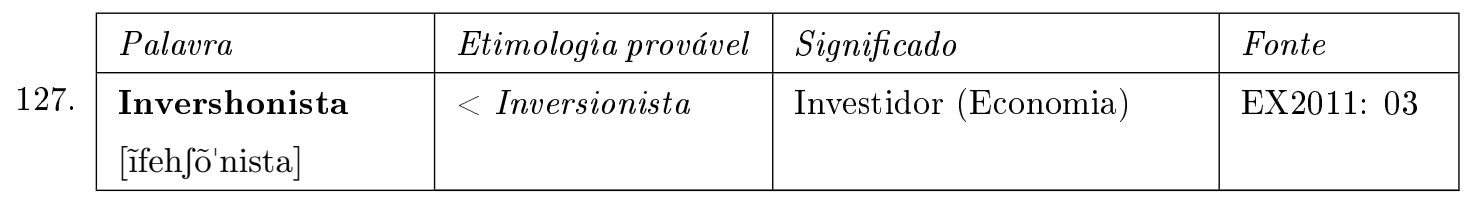

93 Varia com belleging 262 .

94 Varia com belleging 262 . 


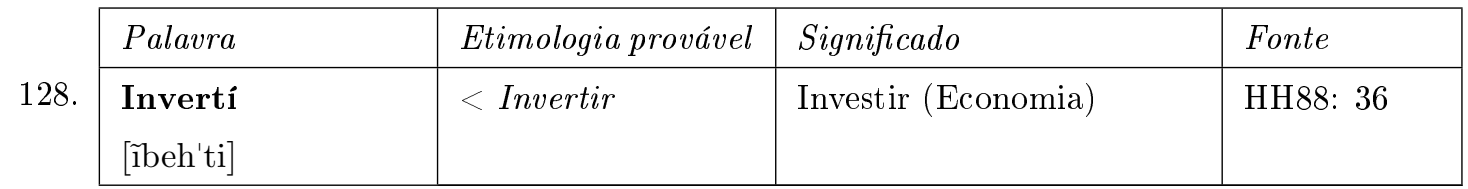

\begin{tabular}{|l|l|l|l|}
\hline Palavra & Etimologia provável & Significado & Fonte \\
\cline { 2 - 5 } & $\begin{array}{l}\text { Kabayeria } \\
{[\text { kabaje'ria }]}\end{array}$ & Cavalaria (Esporte) & RH2008: 115 \\
\hline
\end{tabular}

\begin{tabular}{|l|l|l|l|}
\hline Palavra & Etimologia provável & Significado & Fonte \\
\hline 130. & $\begin{array}{l}\text { Kalkulashon } \\
{[\text { kałkula'fõ }]}\end{array}$ & Cálculo (Economia) & EX2011: 11 \\
\hline
\end{tabular}

\begin{tabular}{|c|c|c|c|c|}
\hline & Palavra & Etimologia provável & Significado & Fonte \\
\hline 131. & $\begin{array}{l}\text { Kaminata }^{95} \\
{[\text { kãmi'nata }]}\end{array}$ & $<$ Caminada & Caminhada (Esporte) & RH2008: 119 \\
\hline
\end{tabular}

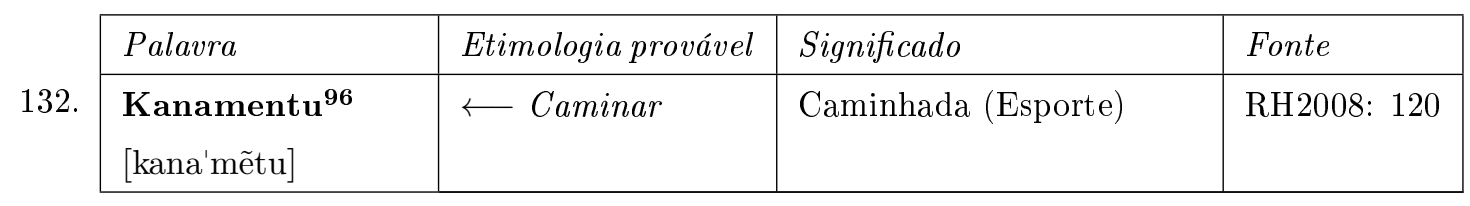

\begin{tabular}{|l|l|l|l|}
\hline Palavra & Etimologia provável & Significado & Fonte \\
\cline { 2 - 4 } & $\begin{array}{l}\text { Kapitan } \\
{[\text { kapi'tã }]}\end{array}$ & Capitão (Esporte) & H44: 28 \\
\hline
\end{tabular}

\begin{tabular}{|l|l|l|l|}
\hline Palavra & Etimologia provável & Significado & Fonte \\
\hline $\begin{array}{l}\text { Karate } \\
\text { [ka'rate] }\end{array}$ & $<$ Kárate, Karate & Karatê (Esporte) & RH2008: 123 \\
\hline
\end{tabular}

\begin{tabular}{|l|l|l|l|}
\hline Palavra & Etimologia provável & Significado & Fonte \\
\hline $\begin{array}{l}\text { Kareda } \\
\text { (ka'reda }]\end{array}$ & $<$ Carrera & Corrida (Esporte) & EX2011: 17 \\
\hline
\end{tabular}

\begin{tabular}{|l|l|l|l|}
\hline Palavra & Etimologia provável & Significado & Fonte \\
\hline Kaseta & $<$ Gaceta & Determinado lugar para se & D86: 170 \\
{$[$ ka'seta $]$} & sentar (beisebol) (Esporte) & \\
& & & \\
\hline
\end{tabular}

\footnotetext{
95 Varia com Kanamentu ${ }_{132}$.

96 Varia com kaminata $a_{131}$.

97 Varia com pustamentu.
} 


\begin{tabular}{|c|c|c|c|}
\hline Palavra & Etimologia provável & Significado & Fonte \\
\hline $\begin{array}{l}\text { 137. } \\
\text { Kayentamentu } \\
\text { [kajẽta'mẽtu }]\end{array}$ & $<$ Calentamiento & Aquecimento (Esporte) & H44: 13 \\
\hline
\end{tabular}

138.

\begin{tabular}{|l|l|l|l|}
\hline Palavra & Etimologia provável & Significado & Fonte \\
\hline $\begin{array}{l}\text { Kentamentu } \\
\text { [kẽta'mẽtu }\end{array}$ & $<$ Calientamento & Aquecimento (Esporte) & OL93: 07 \\
\hline
\end{tabular}

139.

\begin{tabular}{|l|l|l|l|}
\hline Palavra & Etimologia provável & Significado & Fonte \\
\hline $\begin{array}{l}\text { Klasifikashon } \\
{[\text { klasifika'fõ }]}\end{array}$ & $<$ Clasificación & Classificação (Esporte) & OL93: 07 \\
\hline
\end{tabular}

140.

\begin{tabular}{|l|l|l|l|}
\hline Palavra & Etimologia provável & Significado & Fonte \\
\hline $\begin{array}{l}\text { Kolishon } \\
{[\text { koli'fõ }]}\end{array}$ & $<$ Colisión & $\begin{array}{l}\text { Choque entre jogadores } \\
\text { (beisebol) (Esporte) }\end{array}$ & D86: 170 \\
\hline
\end{tabular}

141.

\begin{tabular}{|l|l|l|l|}
\hline Palavra & Etimologia provável & Significado & Fonte \\
\hline $\begin{array}{l}\text { Kombustibel } \mathbf{1 0 0} \\
\text { [kõbus'tibeł }]\end{array}$ & $<$ Combustible & $\begin{array}{l}\text { Combustível (Tecnologia e } \\
\text { Desenvolvimento) }\end{array}$ & EX2011:03 \\
\hline
\end{tabular}

142.

\begin{tabular}{|l|l|l|l|}
\hline Palavra & Etimologia provável & Significado & Fonte \\
\hline $\begin{array}{l}\text { Kombustible } \\
\text { [kõ }\end{array}$ & $<$ Combustible & Combustível (Tecnologia e & RH2008: \\
& & Desenvolvimento) & 133 \\
\hline
\end{tabular}

143

\begin{tabular}{|l|l|l|l|}
\hline Palavra & Etimologia provável & Significado & Fonte \\
\hline $\begin{array}{l}\text { Kompania } \\
\text { [kõpa'nia }]\end{array}$ & $<$ Compañia & $\begin{array}{l}\text { Companhia, comitiva } \\
\text { (Economia) }\end{array}$ & RH2008: 134 \\
& & & \\
\hline
\end{tabular}

144.

\begin{tabular}{|l|l|l|l|}
\hline Palavra & Etimologia provável & Significado & Fonte \\
\hline $\begin{array}{l}\text { Kompania } \\
\text { [kõpa'nia] }\end{array}$ & $<$ Compania & $\begin{array}{l}\text { Companhia (Tecnologia e } \\
\text { Desenvolvimento) }\end{array}$ & EX2011:04 \\
& & & \\
\hline
\end{tabular}

98 Varia com Kentamentu K $_{138}$.

99 Varia com kayentament $u_{137}$.

100 Varia com Kombustible 142 .

101 Varia com Kombustibel Ko1 $_{14}$. 


\begin{tabular}{|l|l|l|l|}
\hline Palavra & Etimologia provável & Significado & Fonte \\
\hline Komputerisá & $<$ Computerizar & Computado-rizar, infor- & RH2008: 134 \\
matizar (Tecnologia e & \\
[kõputeri'sa] & & Desenvolvimento) & \\
& & & \\
\hline
\end{tabular}

\begin{tabular}{|l|l|l|l|}
\hline Palavra & Etimologia provável & Significado & Fonte \\
\hline Komputerisashon & $<$ Computerización & Computado-rização, infor- & RH2008: 135 \\
[kõputerisa'fõ $]$ & & $\begin{array}{l}\text { matização (Tecnologia e } \\
\text { Desenvolvimento) }\end{array}$ & \\
& & & \\
\hline
\end{tabular}

\begin{tabular}{|c|c|c|c|c|}
\hline & Palavra & Etimologia provável & Significado & Fonte \\
\hline 147. & $\begin{array}{l}\text { Komsuptivo } \\
\text { [kõsup'tifo] }\end{array}$ & $<$ Consumptivo & Consumível (Economia) & S85: 05 \\
\hline
\end{tabular}

148.

\begin{tabular}{|l|l|l|l|}
\hline Palavra & Etimologia provável & Significado & Fonte \\
\hline $\begin{array}{l}\text { Konekshon } \\
{\left[\text { kõnek' } \int \tilde{0}\right]}\end{array}$ & $<$ Conexión & $\begin{array}{l}\text { Conexão (Tecnologia e De- } \\
\text { senvolvimento) }\end{array}$ & RH2008: 135 \\
& & & \\
\hline
\end{tabular}

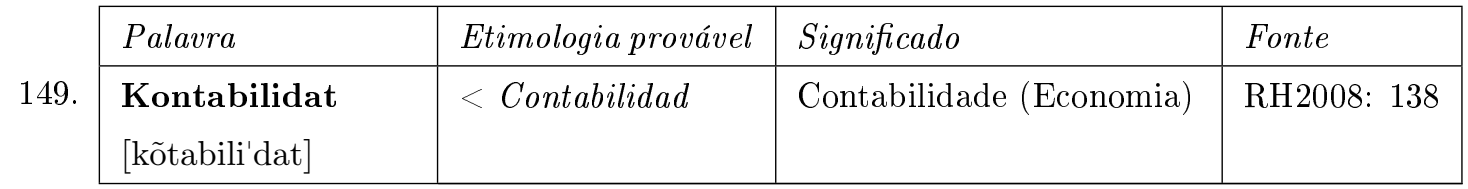

\begin{tabular}{|l|l|l|l|}
\hline Palavra & Etimologia provável & Significado & Fonte \\
\hline Kontrol & $<$ Control & Quando o lançador domina \\
{$[$ kõ'troł $]$} & & Dona de strike (Economia) & 170 \\
& & & \\
\hline
\end{tabular}

\begin{tabular}{|l|l|l|l|}
\hline Palavra & Etimologia provável & Significado & Fonte \\
\hline Koriente & $<$ Corriente & Corrente de eletricidade & RH2008: \\
[ko'rjẽte] & & $\begin{array}{l}\text { (Tecnologia e Desenvolvi- } \\
\text { mento) }\end{array}$ & 139 \\
& & & \\
\hline
\end{tabular}

\begin{tabular}{|c|c|c|c|c|}
\hline \multirow[b]{2}{*}{152.} & Palavra & Etimologia provável & Significado & Fonte \\
\hline & $\begin{array}{l}\text { Korner } \\
\text { ['kohneh] }\end{array}$ & $<$ Córner & Escanteio (Esporte) & $\mathrm{H} 44: 49$ \\
\hline \multirow[b]{2}{*}{153.} & Palavra & Etimologia provável & Significado & Fonte \\
\hline & $\begin{array}{l}\text { Kosto } \\
\text { ['kosto] }\end{array}$ & $<$ Costo & Custo (Economia) & RH2008: 141 \\
\hline
\end{tabular}




\begin{tabular}{|c|c|c|c|}
\hline Palavra & Etimologia provável & Significado & Fonte \\
\hline \begin{tabular}{l|l}
154. & Kosto di bida \\
{$[$ 'kosto $][$ di $][$ 'bida $]$}
\end{tabular} & $<$ Costo de vida & Custo de vida (Economia) & S85: 13 \\
\hline
\end{tabular}

\begin{tabular}{|l|l|l|l|}
\hline Palavra & Etimologia provável & Significado & Fonte \\
\cline { 2 - 4 } & $\begin{array}{l}\text { Kostoso } \\
{[\text { kos'toso }]}\end{array}$ & Custoso (Economia) & RH2008: 141 \\
\hline
\end{tabular}

\begin{tabular}{|c|c|c|c|c|}
\hline & Palavra & Etimologia provável & Significado & Fonte \\
\hline 156. & $\begin{array}{l}\text { Kreket }^{102} \\
\text { ['krekct] }\end{array}$ & $<$ Cricket & Críquete (Esporte) & P92: 48 \\
\hline
\end{tabular}

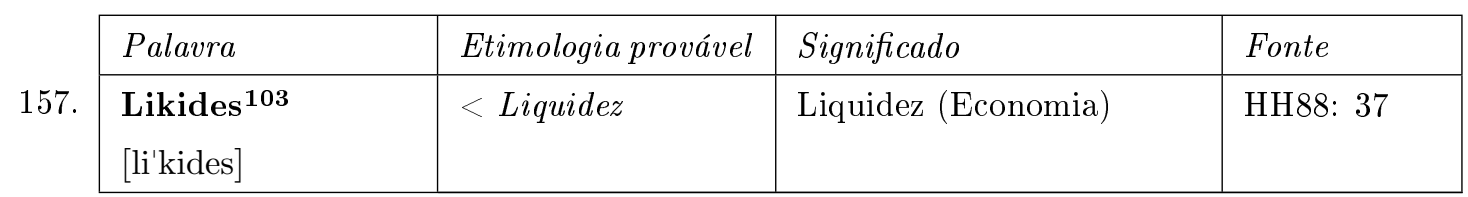

\begin{tabular}{|l|l|l|l|}
\hline Palavra & Etimologia provável & Significado & Fonte \\
\hline Liña & $<$ Liña & Bola que é batida com & D86: 171 \\
muita força (beisebol) (Es- & \\
['lĩna] & & porte) & \\
\hline
\end{tabular}

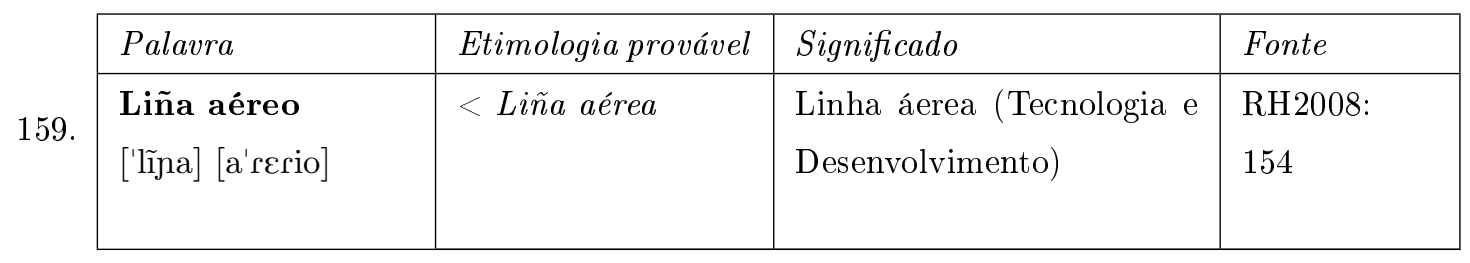

\begin{tabular}{|c|c|c|c|c|}
\hline & Palavra & Etimologia provável & Significado & Fonte \\
\hline 160. & $\begin{array}{l}\text { Liña di banda } \\
\text { ['lĩna] [di] ['bãda] }\end{array}$ & $<\operatorname{Lin} a / B a n d a$ & Linha lateral (Esporte) & H44: 29 \\
\hline
\end{tabular}

\begin{tabular}{|c|c|c|c|c|}
\hline & Palavra & Etimologia provável & Significado & Fonte \\
\hline 161. & $\begin{array}{l}\text { Liña di gol } \\
\text { ['lĩna] [di] ['goł] }\end{array}$ & $<$ Liña de gol & Linha do gol (Esporte) & C2010: 11 \\
\hline
\end{tabular}

\begin{tabular}{|l|l|l|l|}
\hline Palavra & Etimologia provável & Significado & Fonte \\
\cline { 2 - 4 } & $\begin{array}{l}\text { Lucha } \\
\text { ['lutja] }\end{array}$ & Luta (Esporte) & P92: 25 \\
\hline
\end{tabular}

102 Varia com croquet $_{922}$.

103 Varia com liquiditeit ${ }_{318}$. 


\begin{tabular}{|c|c|c|c|c|}
\hline & Palavra & Etimologia provável & Significado & Fonte \\
\hline 163. & $\begin{array}{l}\text { Lus di tráfiko } \\
\text { ['lus][di] ['trafiko] }\end{array}$ & $<L u z /$ Tráfico & $\begin{array}{l}\text { Semáforo (Tecnologia e } \\
\text { Desenvolvimento) }\end{array}$ & $\begin{array}{l}\text { RH2008: } \\
157\end{array}$ \\
\hline & Palavra & Etimologia provável & Significado & Fonte \\
\hline 164. & $\begin{array}{l}\text { Lus eléktriko } \\
\text { ['lus] [E'lektriko] }\end{array}$ & $<$ Luz eléctrica & $\begin{array}{l}\text { Luz elétrica (Tecnologia e } \\
\text { Desenvolvimento) }\end{array}$ & $\begin{array}{l}\text { RH2008: } \\
157\end{array}$ \\
\hline
\end{tabular}

\begin{tabular}{|l|l|l|l|}
\hline Palavra & Etimologia provável & Significado & Fonte \\
\hline Manager & $<$ Mánager & $\begin{array}{l}\text { Autoridade máxima da } \\
\text { equipe de beisebol (Es- } \\
\text { porte) }\end{array}$ & \\
& & & \\
& & & \\
\hline
\end{tabular}

\begin{tabular}{|l|l|l|l|}
\hline 166. & Etimologia provável & Significado & Fonte \\
\hline $\begin{array}{l}\text { Manehá } \\
\text { [mane'ha }]\end{array}$ & $<$ Manejar & $\begin{array}{l}\text { Dirigir (Tecnologia e De- } \\
\text { senvolvimento) }\end{array}$ & $\begin{array}{l}\text { RH2008: } \\
246\end{array}$ \\
\hline
\end{tabular}

\begin{tabular}{|c|c|c|c|c|}
\hline & Palavra & Etimologia provável & Significado & Fonte \\
\hline 167. & $\begin{array}{l}\text { Mantenshon } \\
{[\text { mãtẽ'fõ }]}\end{array}$ & $<$ Manutención & Manutenção (Economia) & S85: 05 \\
\hline
\end{tabular}

\begin{tabular}{|c|c|c|c|c|}
\hline & Palavra & Etimologia provável & Significado & Fonte \\
\hline 168. & $\begin{array}{l}\text { Maraton } \\
\text { [mara'tõ] }\end{array}$ & $<$ Maratón & Maratona (Esporte) & RH2008: 162 \\
\hline
\end{tabular}

\begin{tabular}{|c|c|c|c|c|}
\hline & Palavra & Etimologia provável & Significado & Fonte \\
\hline 169. & $\begin{array}{l}\text { Merkansia } \\
\text { [mehkã'sia] }\end{array}$ & $<$ Mercancias & Mercadoria (Economia) & RH2008: 166 \\
\hline
\end{tabular}

\begin{tabular}{|c|c|c|c|c|}
\hline & Palavra & Etimologia provável & Significado & Fonte \\
\hline 170. & $\begin{array}{l}\text { Miembro di con- } \\
\text { seho } \\
{[\text { 'mjẽbro] }} \\
{[\text { kõ'seho }}\end{array}$ & $\begin{array}{l}<\text { Miembro de con- } \\
\text { sejo }\end{array}$ & Conselheiro (Política) & EX2011:03 \\
\hline \multirow[b]{2}{*}{171.} & Palavra & Etimologia provável & Significado & Fonte \\
\hline & $\begin{array}{l}\text { Moneda } \\
{[\text { mõ'neda] }}\end{array}$ & $<$ Moneda & Moeda (Economia) & RH2008: 169 \\
\hline
\end{tabular}

104 Varia com Stir 381 e Stür 385. 
172

\begin{tabular}{|l|l|l|l|}
\hline Palavra & Etimologia provável & Significado & Fonte \\
\hline $\begin{array}{l}\text { Narkósis } \\
\text { [nah'kosis }]\end{array}$ & $<$ Narcosis & $\begin{array}{l}\text { Narcose (Tecnologia e De- } \\
\text { senvolvimento) }\end{array}$ & RH2008: \\
& & & 174 \\
\hline
\end{tabular}

173

\begin{tabular}{|c|c|c|c|}
\hline Palavra & Etimologia provável & Significado & Fonte \\
\hline $\begin{array}{l}\text { Narkotrafikashon } \\
{[\text { nahkotrafika'fõ] }}\end{array}$ & $\longleftarrow$ Traficación & $\begin{array}{l}\text { Tráfico de entorpecentes } \\
\text { ou drogas (Tecnologia e } \\
\text { Desenvolvimento) }\end{array}$ & $\begin{array}{l}\text { RH2008: } \\
174\end{array}$ \\
\hline
\end{tabular}

174.

\begin{tabular}{|l|l|l|l|}
\hline Palavra & Etimologia provável & Significado & Fonte \\
\hline $\begin{array}{l}\text { Natashon } \\
\text { [nata'fó }]\end{array}$ & $<$ Natación & Natação (Esporte) & P92: 25 \\
\hline
\end{tabular}

175.

\begin{tabular}{|l|l|l|l|}
\hline Palavra & Etimologia provável & Significado & Fonte \\
\hline $\begin{array}{l}\text { Natashon sinkro- } \\
\text { nisá } \\
\text { [nata'fõ] [sĩkrõni'sa] }\end{array}$ & $\begin{array}{l}<\text { Natación sicroni- } \\
\text { zada }\end{array}$ & $\begin{array}{l}\text { Nado sicronizado (Es- } \\
\text { porte) }\end{array}$ & P92: 48 \\
\hline
\end{tabular}

\begin{tabular}{|l|l|l|l|}
\hline Palavra & Etimologia provável & Significado & Fonte \\
\hline $\begin{array}{l}\text { Negoshi por de- } \\
\text { tal } \\
{[\mathrm{ne} \text { 'gJ } \mathrm{i}] \quad[\mathrm{poh}]} \\
{[\mathrm{de} \text { 'tat }]}\end{array}$ & $<$ Negocio por detal & $\begin{array}{l}\text { Negócio por varejo (Econo- } \\
\text { mia) }\end{array}$ & RH2008: 175 \\
\hline
\end{tabular}

177.

\begin{tabular}{|l|l|l|l|}
\hline Palavra & Etimologia provável & Significado & Fonte \\
\hline $\begin{array}{l}\text { Negosiashon } \\
\text { [negosia'fõ] }\end{array}$ & $<$ Negociación & Negociação (Economia) & RH2008: 174 \\
\hline
\end{tabular}

178.

\begin{tabular}{|l|l|l|l|}
\hline Palavra & Etimologia provável & Significado & Fonte \\
\hline $\begin{array}{l}\text { Notisiero106 } \\
\text { [noti'siero] }\end{array}$ & $<$ Noticiero & $\begin{array}{l}\text { Jornalista (Tecnologia e } \\
\text { Desenvolvimento) }\end{array}$ & RH2008: \\
& & 178 \\
\hline
\end{tabular}

179

\begin{tabular}{|l|l|l|l|}
\hline Palavra & Etimologia provável & Significado & Fonte \\
\hline $\begin{array}{l}\text { Omnibùs }{ }^{\mathbf{1 0 7}} \\
\text { [õmini'bøs] }\end{array}$ & $<$ Ómnibus & $\begin{array}{l}\text { Ônibus (Tecnologia e De- } \\
\text { senvolvimento) }\end{array}$ & $\begin{array}{l}\text { RH2008: } \\
181\end{array}$ \\
\hline
\end{tabular}

105 Varia com landamentu ${ }_{720}$.

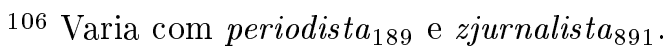

107 Varia com outobùs ${ }_{338}$, konvoi $_{312}$ e bùs ${ }_{264}$. 


\begin{tabular}{|l|l|l|l|}
\hline Palavra & Etimologia provável & Significado & Fonte \\
\hline $\begin{array}{l}\text { Outomashon } \\
\text { [owtoma'fõ }]\end{array}$ & $<$ Automación & $\begin{array}{l}\text { Automação (Tecnologia e } \\
\text { Desenvolvimento) }\end{array}$ & RH2008: \\
& & & 185 \\
\hline
\end{tabular}

\begin{tabular}{|c|c|c|c|c|}
\hline & Palavra & Etimologia provável & Significado & Fonte \\
\hline 181. & $\begin{array}{l}\text { Outomatisashon } \\
\left.\text { [owtomatiza' } \int \tilde{o}\right]\end{array}$ & $<$ Automatización & $\begin{array}{l}\text { Automatização (Tecnolo- } \\
\text { gia e Desenvolvimento) }\end{array}$ & RH2008: 185 \\
\hline
\end{tabular}

182.

\begin{tabular}{|l|l|l|l|}
\hline Palavra & Etimologia provável & Significado & Fonte \\
\hline $\begin{array}{l}\text { Pakete di medida } \\
\text { [pa'kete }] \quad \text { Paquete de me- }\end{array}$ & Pacote de medidas (Econo- & S85: 10 \\
{$[$ me'dida $]$} & & mia) & \\
\hline
\end{tabular}

183

\begin{tabular}{|l|l|l|l|}
\hline Palavra & Etimologia provável & Significado & Fonte \\
\hline $\begin{array}{l}\text { Palabrá } \\
\text { [pala'bra] }\end{array}$ & $<$ Apalabrar & Fazer o acordo verbal- & S85: 10 \\
& & mente (Economia) & \\
\hline
\end{tabular}

\begin{tabular}{|l|l|l|l|}
\hline Palavra & Etimologia provável & Significado & Fonte \\
\hline $\begin{array}{l}\text { Pasahero } \\
\text { [pasa'hero] }\end{array}$ & $<$ Pasajero & $\begin{array}{l}\text { Passageiro (Tecnologia e } \\
\text { Desenvolvimento) }\end{array}$ & 245 \\
\hline
\end{tabular}

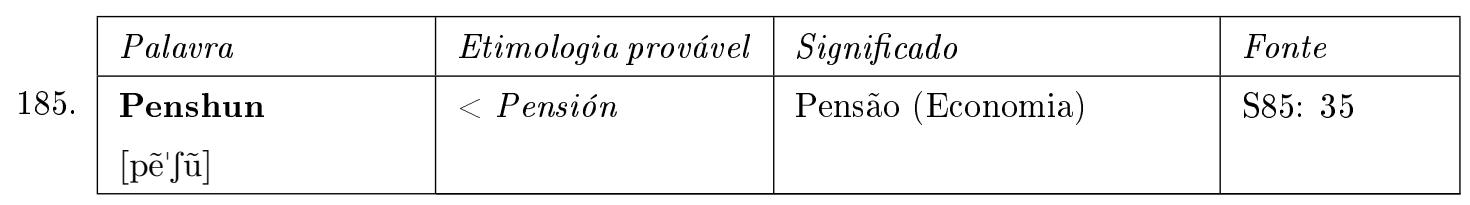

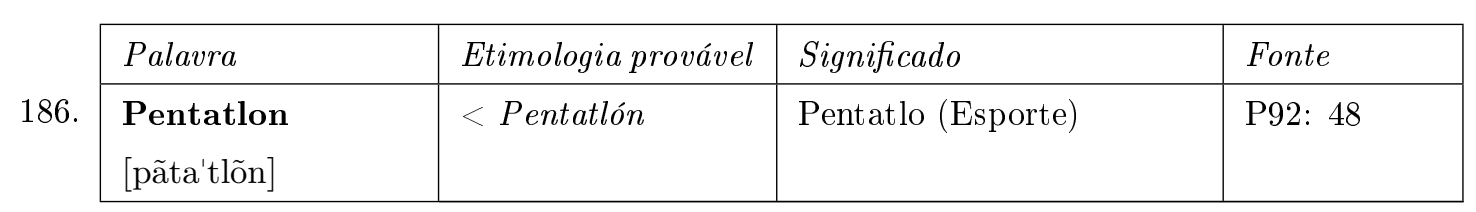

\begin{tabular}{|l|l|l|l|}
\hline Palavra & Etimologia provável & Significado & Fonte \\
\hline $\begin{array}{l}\text { Periódiko } \\
\text { [peri'odiko] }\end{array}$ & $<$ Periódico & $\begin{array}{l}\text { Jornal (Tecnologia e De- } \\
\text { senvolvimento) }\end{array}$ & $\begin{array}{l}\text { RH2008: } \\
195\end{array}$ \\
\hline
\end{tabular}

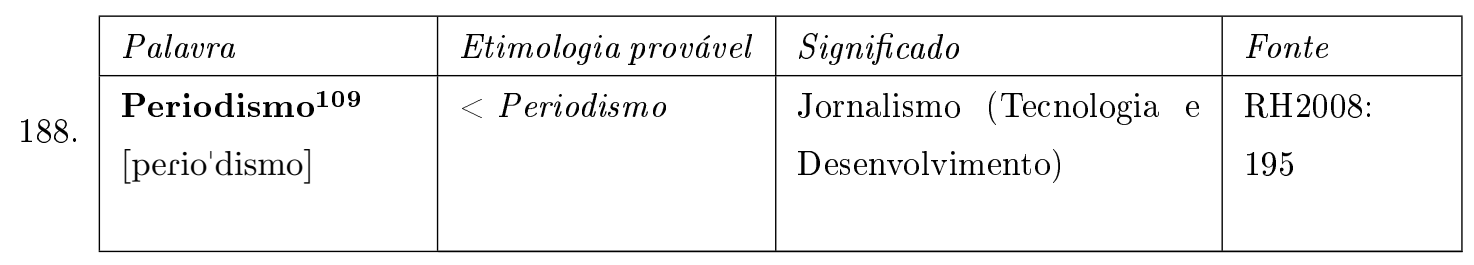

108 Varia com korant 313 .

109 Varia com zjurnalismo 890 . 


\begin{tabular}{|l|l|l|l|}
\hline Palavra & Etimologia provável & Significado & Fonte \\
\hline $\begin{array}{l}\text { Periodista } \\
\text { [110 }\end{array}$ & $<$ Periodista & Jornalista (Tecnologia e & RH2008: \\
& & Desenvolvimento) & 195 \\
\hline
\end{tabular}

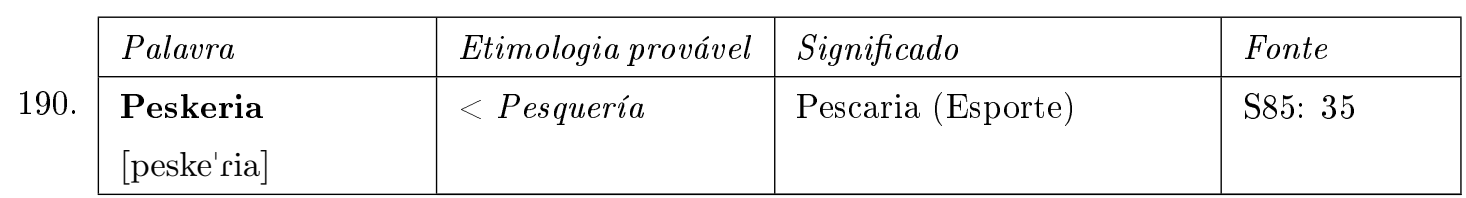

\begin{tabular}{|c|c|c|c|c|}
\hline \multirow[b]{2}{*}{191.} & Palavra & Etimologia provável & Significado & Fonte \\
\hline & 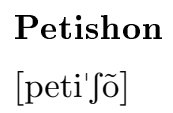 & $<$ Petición & Petição (Economia) & EX2011: 05 \\
\hline \multirow[b]{2}{*}{192.} & Palavra & Etimologia provável & Significado & Fonte \\
\hline & $\begin{array}{l}\text { Picheo } \\
\text { ['pitfew] }\end{array}$ & $<$ Pitcheo & $\begin{array}{l}\text { Arremesso de bola (Es- } \\
\text { porte) }\end{array}$ & RH2008: 197 \\
\hline
\end{tabular}

\begin{tabular}{|c|c|c|c|c|}
\hline & Palavra & Etimologia provável & Significado & Fonte \\
\hline 193. & $\begin{array}{l}\text { Pinpòn } \\
\text { [pĩ'põ] }\end{array}$ & $<$ Ping-pong & Pingue-pongue (Esporte) & RH2008: 199 \\
\hline
\end{tabular}

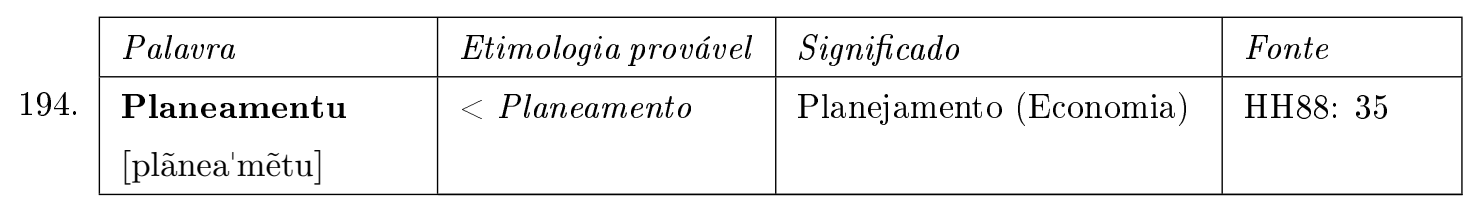

\begin{tabular}{|l|l|l|l|}
\hline Palavra & Etimologia provável & Significado & Fonte \\
\hline $\begin{array}{l}\text { Plaso } \\
{[\text { 'plaso] }}\end{array}$ & $<$ Plazo & Prazo (Economia) & S85: 31 \\
\hline
\end{tabular}

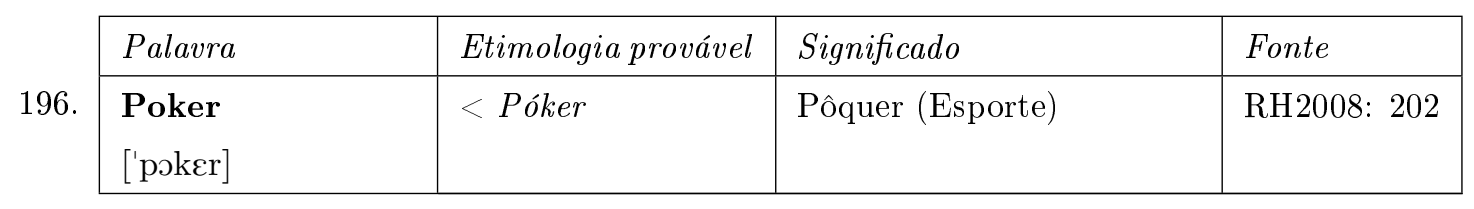

\begin{tabular}{|l|l|l|l|}
\hline 197. & Etimologia provável & Significado & Fonte \\
\hline $\begin{array}{l}\text { Porsentahe } \\
\text { [pohsẽ'tahe] }\end{array}$ & $<$ Porcentaje & Porcentagem (Economia) & S85: 13 \\
\hline
\end{tabular}

\begin{tabular}{|l|l|l|l|}
\hline 198. & Etimologia provável & Significado & Fonte \\
\cline { 2 - 4 } & $\begin{array}{l}\text { Portero } \\
\text { [poh'tero] }\end{array}$ & Goleiro (Esporte) & H44: 28 \\
\hline
\end{tabular}

110 Varia com zjurnalista $a_{891}$ e notisiero ${ }_{178}$.

111 Varia com golkiper $_{453}$ e kiper $_{471}$. 


\begin{tabular}{|l|l|l|l|}
\hline Palavra & Etimologia provável & Significado & Fonte \\
\hline $\begin{array}{l}\text { Postpago } \\
\text { [powst'pago] }\end{array}$ & $<$ Postpago & $\begin{array}{l}\text { Pós-pago (Tecnologia e De- } \\
\text { senvolvimento) }\end{array}$ & EX2011:04 \\
\hline
\end{tabular}

200.

\begin{tabular}{|l|l|l|l|}
\hline Palavra & Etimologia provável & Significado & Fonte \\
\hline $\begin{array}{l}\text { Preshon } \\
{\left[\text { pre' } \int \tilde{0}\right]}\end{array}$ & $<$ Precio & Preço (Economia) & EX2011: 15 \\
\hline
\end{tabular}

\begin{tabular}{|c|c|c|c|c|}
\hline & Palavra & Etimologia provável & Significado & Fonte \\
\hline 201. & $\begin{array}{l}\text { Presupuestario } \\
\text { [presupwes'tario] }\end{array}$ & $<$ Presupuestario & Orçamental (Economia) & RH2008: 206 \\
\hline
\end{tabular}

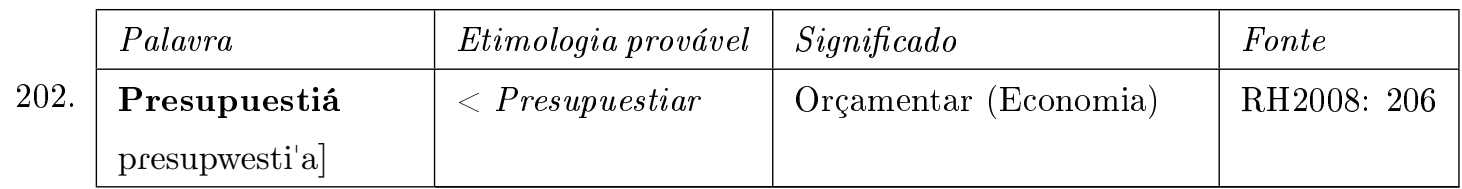

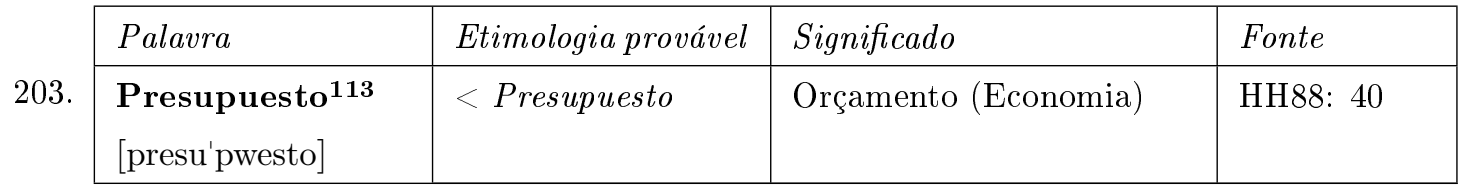

\begin{tabular}{|c|c|c|c|c|}
\hline & Palavra & Etimologia provável & Significado & Fonte \\
\hline 204. & $\begin{array}{l}\text { Privatisashon } \\
\text { [prifatiza'fõ] }\end{array}$ & $<$ Privatización & Privatização (Economia) & EX2011: 13 \\
\hline
\end{tabular}

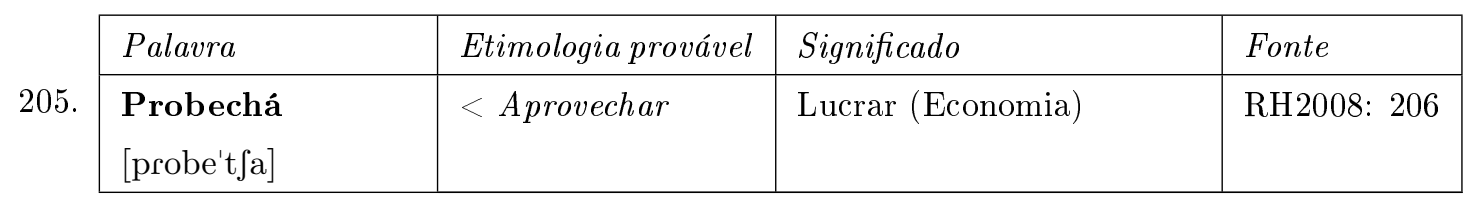

\begin{tabular}{|l|l|l|l|}
\hline Palavra & Etimologia provável & Significado & Fonte \\
\hline $\begin{array}{l}\text { Probechadó } \\
\text { [probetja'do] }\end{array}$ & $<$ Aprovechador & $\begin{array}{l}\text { Aquele que lucra (Econo- } \\
\text { mia) }\end{array}$ & RH2008: 206 \\
\hline
\end{tabular}

\begin{tabular}{|l|l|l|l|}
\hline 207. & Etimologia provável & Significado & Fonte \\
\hline $\begin{array}{l}\text { Probecho } \\
{[\text { pro'betso }]}\end{array}$ & $<$ Provecho & Lucro (Economia) & RH2008: 206 \\
\hline
\end{tabular}

\begin{tabular}{|c|c|c|c|c|}
\hline & Palavra & Etimologia provável & Significado & Fonte \\
\hline 208. & $\begin{array}{l}\text { Probechoso } \\
\text { [probe'tfoso] }\end{array}$ & $<$ Provechoso & Lucrativo (Economia) & RH2008: 206 \\
\hline
\end{tabular}

112 Varia com preis 348 .

113 Varia com belasting ${ }_{261}$ e impuesto $_{117}$. 


\begin{tabular}{|c|c|c|c|}
\hline Palavra & Etimologia provável & Significado & Fonte \\
\hline $\begin{array}{l}\text { 209. } \\
\text { Produkshon } \\
{\left[\operatorname{produk} \int \tilde{\mathrm{o}}\right]}\end{array}$ & $<$ Producción & Produção (Economia) & EX2011: 10 \\
\hline
\end{tabular}

\begin{tabular}{|l|l|l|l|}
\hline 210. & Etimologia provável & Significado & Fonte \\
\cline { 2 - 4 } & $\begin{array}{l}\text { Produkto } \\
\text { [pro'dukto }]\end{array}$ & Produto (Economia) & EX2011: 10 \\
\hline
\end{tabular}

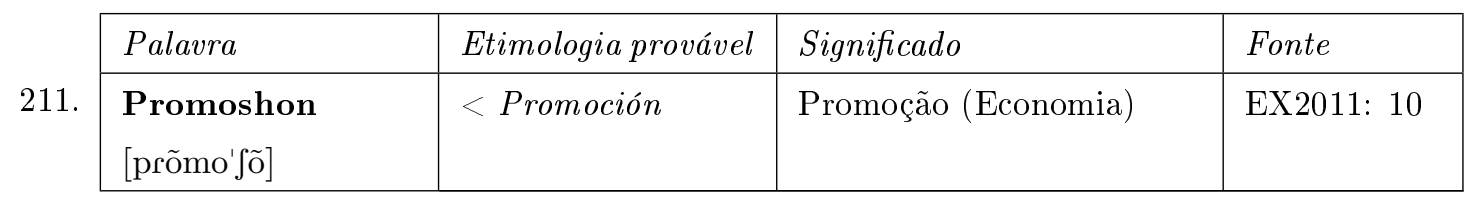

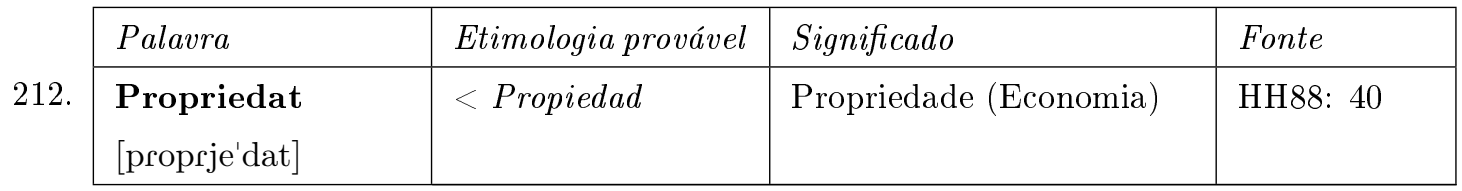

\begin{tabular}{|l|l|l|l|}
\hline 213. & Etimologia provável & Significado & Fonte \\
\cline { 2 - 4 } & $\begin{array}{l}\text { Proyekto } \\
\text { [pro'jekto] }\end{array}$ & Projeto (Economia) & HH88: 40 \\
\hline
\end{tabular}

\begin{tabular}{|l|l|l|l|l|}
\hline 214. & Etimologia provável & Significado & Fonte \\
\cline { 2 - 5 } & $\begin{array}{l}\text { Puntuashon } \\
\text { [pũtua'fõ] }\end{array}$ & $<$ Puntuacion & Pontuação (Esporte) & OL93: 07 \\
\hline
\end{tabular}

\begin{tabular}{|l|l|l|l|}
\hline Palavra & Etimologia provável & Significado & Fonte \\
\hline $\begin{array}{l}\text { Radioaktividat } \\
\text { [radioaktifi'dat }]\end{array}$ & $<$ Radioactividad & $\begin{array}{l}\text { Radioatividade (Tecnolo- } \\
\text { gia e Desenvolvimento) }\end{array}$ & 211 \\
\hline
\end{tabular}

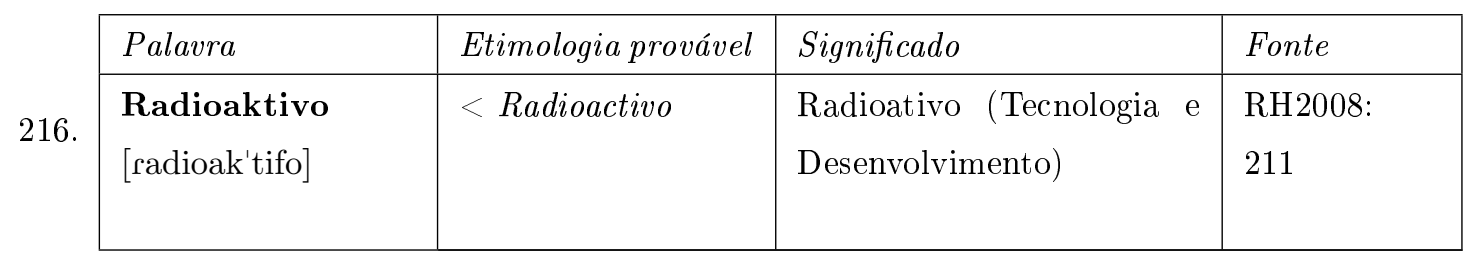

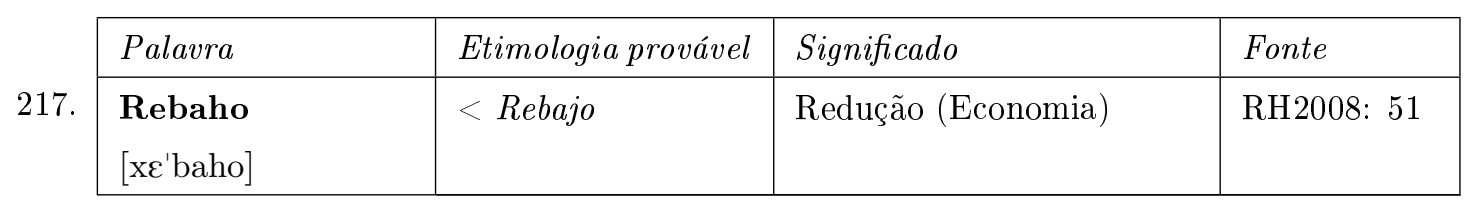

\begin{tabular}{|l|l|l|l|l|}
\hline 218. & Etimologia provável & Significado & Fonte \\
\cline { 2 - 4 } & $\begin{array}{l}\text { Redusibel } \\
\text { [xedu'sibeł }]\end{array}$ & $<$ Reducible & Redutível (Economia) & S85: 31 \\
\hline
\end{tabular}




\begin{tabular}{|l|l|l|l|}
\hline Palavra & Etimologia provável & Significado & Fonte \\
\hline $\begin{array}{l}\text { Refinashon } \\
\text { [xefina'fõ }]\end{array}$ & $<$ Refinación & $\begin{array}{l}\text { Refinamento (Tecnologia e } \\
\text { Desenvolvimento) }\end{array}$ & EX2011:05 \\
& & & \\
\hline
\end{tabular}

220.

\begin{tabular}{|l|l|l|l|}
\hline Palavra & Etimologia provável & Significado & Fonte \\
\hline $\begin{array}{l}\text { Refineria } \\
\text { [xefine'ria] }\end{array}$ & $<$ Refinería & $\begin{array}{l}\text { Refinaria (Tecnologia e De- } \\
\text { senvolvimento) }\end{array}$ & EX2011:05 \\
& & & \\
\hline
\end{tabular}

221.

\begin{tabular}{|l|l|l|l|}
\hline Palavra & Etimologia provável & Significado & Fonte \\
\hline $\begin{array}{l}\text { Rèfri114 } \\
\text { ['refri] }\end{array}$ & $<$ Referí & Juíz (árbitro) (Esporte) & C2010: 16 \\
\hline
\end{tabular}

222 .

\begin{tabular}{|l|l|l|l|}
\hline Palavra & Etimologia provável & Significado & Fonte \\
\hline Rèfri asistente & $<$ Referí / Asis- & Juiz assistente (árbitro as- & C2010: 19 \\
['refri] [asis'tẽte] & tente & sistente) (Esporte) & \\
& & & \\
\hline
\end{tabular}

223 .

\begin{tabular}{|l|l|l|l|}
\hline Palavra & Etimologia provável & Significado & Fonte \\
\hline $\begin{array}{l}\text { Regla } \\
{[\text { 'xegla }]}\end{array}$ & $<$ Regla & Regra (Esporte) & D86: 19 \\
\hline
\end{tabular}

\begin{tabular}{|l|l|l|l|}
\hline Palavra & Etimologia provável & Significado & Fonte \\
\cline { 2 - 4 } & $\begin{array}{l}\text { Riesgo } \\
\text { ['rjesgo] }\end{array}$ & Risco (Economia) & HH88: 22 \\
\hline
\end{tabular}

\begin{tabular}{|l|l|l|l|}
\hline Palavra & Etimologia provável & Significado & Fonte \\
\hline Robo & $<$ Robo & Jogador toma uma base & D86: 174 \\
['robo] & & $\begin{array}{l}\text { por seu próprio risco (bei- } \\
\text { sebol) (Esporte) }\end{array}$ & \\
& & & \\
\hline
\end{tabular}

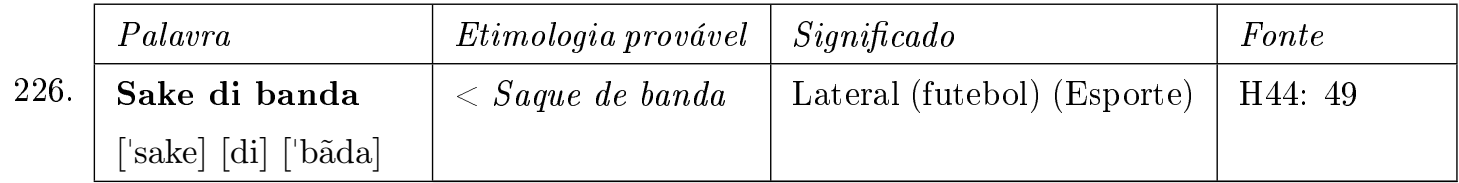

\begin{tabular}{|l|l|l|l|}
\hline 227. & Etimologia provável & Significado & Fonte \\
\cline { 2 - 5 } & $\begin{array}{l}\text { Sektor } \\
\text { [sek'toh] }\end{array}$ & Setor (Economia) & EX2011: 05 \\
\hline
\end{tabular}

114 Varia com arbitradó 19 . 


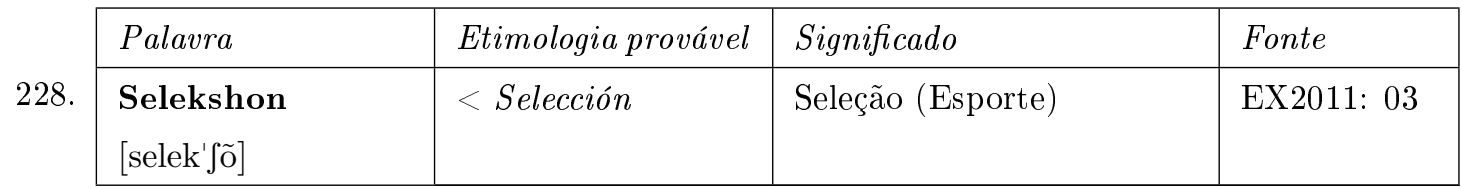

229.

\begin{tabular}{|l|l|l|l|}
\hline Palavra & Etimologia provável & Significado & Fonte \\
\hline $\begin{array}{l}\text { Sencillo } \\
\text { [sẽ'siyo] }\end{array}$ & $<$ Sencillo & $\begin{array}{l}\text { Lançamento que só alcança } \\
\text { uma base (Esporte) }\end{array}$ & D86: 175 \\
& & & \\
\hline
\end{tabular}

\begin{tabular}{|c|c|c|c|c|}
\hline & Palavra & Etimologia provável & Significado & Fonte \\
\hline 230 & $\begin{array}{l}\text { Sòfbòl115 } \\
\text { [sof'boł] }\end{array}$ & $<$ Sofbol & $\begin{array}{l}\text { Softbol, beisebol jogado } \\
\text { com bola macia (Esporte) }\end{array}$ & RH2008: 241 \\
\hline
\end{tabular}

\begin{tabular}{|l|l|l|l|}
\hline Palavra & Etimologia provável & Significado & Fonte \\
\cline { 2 - 4 } & $\begin{array}{l}\text { Sosiedat } \\
\text { [sosje'dat }]\end{array}$ & $\begin{array}{l}\text { Sociedade, ser sócio (Eco- } \\
\text { nomia) }\end{array}$ & HH88: 33 \\
\hline
\end{tabular}

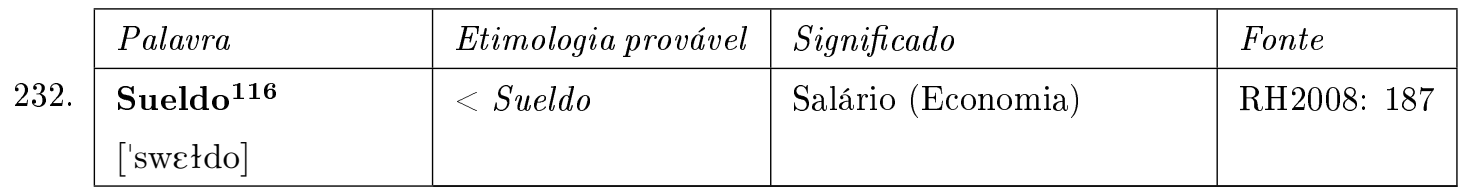

\begin{tabular}{|l|l|l|l|l|}
\hline 233. & Palavra & Etimologia provável & Significado & Fonte \\
\cline { 2 - 4 } & $\begin{array}{l}\text { Sueldu } \mathbf{1 1 7} \\
\text { ['swełdo] }\end{array}$ & Salário (Economia) & RH2008: 187 \\
\hline
\end{tabular}

\begin{tabular}{|l|l|l|l|}
\hline 234. & Etimologia provável & Significado & Fonte \\
\cline { 2 - 4 } & $\begin{array}{l}\text { Suma } \\
{[\text { 'suma }]}\end{array}$ & Soma (Economia) & S85: 18 \\
\hline
\end{tabular}

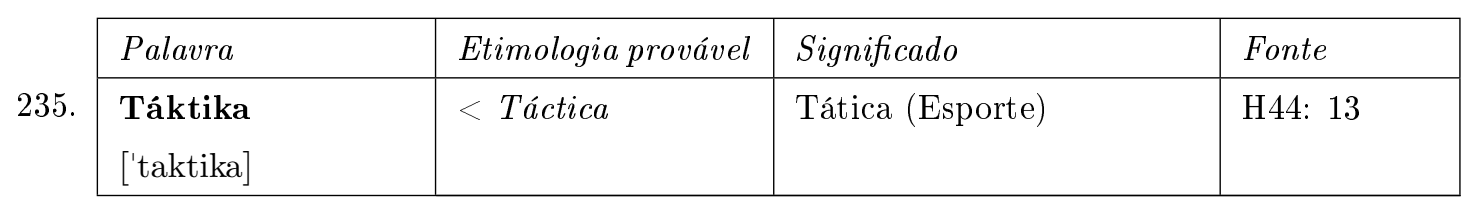

\begin{tabular}{|c|c|c|c|}
\hline Palavra & Etimologia provável & Significado & Fonte \\
\hline $\begin{array}{l}\text { Tangana } \\
\text { [tãgãnã] }\end{array}$ & $<$ Tangana & $\begin{array}{l}\text { Jogador contra jogador } \\
\text { (beisebol) (Esporte) }\end{array}$ & D86: 176 \\
\hline
\end{tabular}

\footnotetext{
115 Varia com sòftbol 373 .

116 Varia com Sueldu $u_{233}$.

117 Varia com Sueldo ${ }_{232}$.
} 


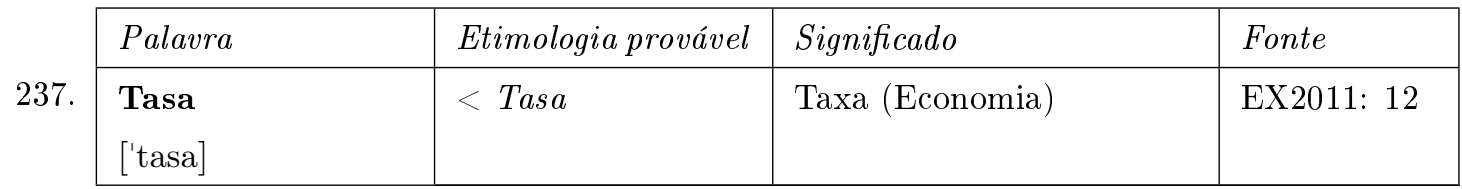

238.

\begin{tabular}{|l|l|l|l|}
\hline Palavra & Etimologia provável & Significado & Fonte \\
\hline Telekomunikashon & $<$ Telecomunica- & Telecomuni-cação (Tecno- & RH2008: \\
[telekõmunika'fõ] & ción & logia e Desenvolvimento) & 254 \\
& & & \\
\hline
\end{tabular}

239.

\begin{tabular}{|l|l|l|l|}
\hline Palavra & Etimologia provável & Significado & Fonte \\
\hline Televishon & $<$ Televisión & Televisão (Tecnologia e & RH2008: \\
[telefi'fõ] & & Desenvolvimento) & 255 \\
& & & \\
\hline
\end{tabular}

240.

\begin{tabular}{|l|l|l|l|}
\hline Palavra & Etimologia provável & Significado & Fonte \\
\hline $\begin{array}{l}\text { Tiradó di flecha } \\
\text { [tira'do] [di] ['flet]a] }\end{array}$ & $<$ Tirador de flecha & $\begin{array}{l}\text { Atirador de flecha (Es- } \\
\text { porte) }\end{array}$ & RH2008: 257 \\
& & & \\
\hline
\end{tabular}

\begin{tabular}{|lr|l|l|l|}
\hline Palavra & Etimologia provável & Significado & Fonte \\
\hline $\begin{array}{l}\text { Tiramentu di } \\
\text { disco } \\
{[\text { tira'mẽtu }]} \\
{[\text { 'disko }]}\end{array}$ & $\begin{array}{l}\text { Disco } \\
\text { Tirar }]\end{array}$ & & $\begin{array}{l}\text { Lançamento de disco (Es- } \\
\text { porte) }\end{array}$ & EX2011: 10 \\
& & & \\
\hline
\end{tabular}

\begin{tabular}{|l|l|l|l|l|}
\hline 242. & Palavra & Etimologia provável & Significado & Fonte \\
\cline { 2 - 4 } & $\begin{array}{l}\text { Tiru di skina } \\
\text { ['tiru] [di] [is'kina] }\end{array}$ & $<$ Tiro de esquina & Escanteio & H44: 49 \\
\hline
\end{tabular}

\begin{tabular}{|l|l|l|l|l|}
\hline 243. & Palavra & Etimologia provável & Significado & Fonte \\
\cline { 2 - 5 } & $\begin{array}{l}\text { Tiru liber } \\
{[\text { 'tiru] ['liber] }}\end{array}$ & $<$ Tiro libre & Tiro livre (Esporte) & H44: 29 \\
\hline
\end{tabular}

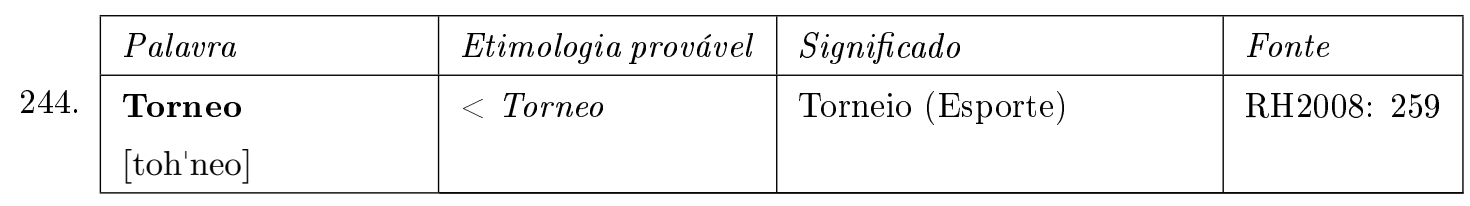

\begin{tabular}{|l|l|l|l|l|}
\hline 245. & Etimologia provável & Significado & Fonte \\
\cline { 2 - 4 } & $\begin{array}{l}\text { Trabou } \\
\text { [tra'bow }]\end{array}$ & Trabalho (Economia) & S85: 45 \\
\hline
\end{tabular}




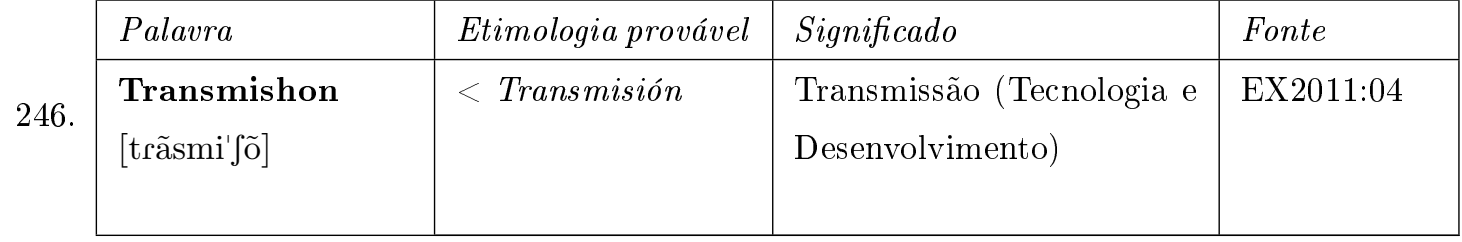

\begin{tabular}{|c|c|c|c|c|}
\hline & Palavra & Etimologia provável & Significado & Fonte \\
\hline 247. & $\begin{array}{l}\text { Trapesio } \\
\text { [tra'pesio] }\end{array}$ & $<$ Trapecio & Trapézio (Esporte) & RH2008: 261 \\
\hline
\end{tabular}

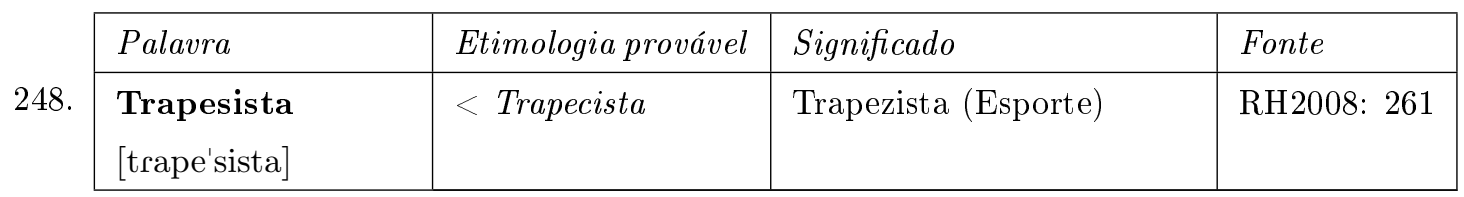

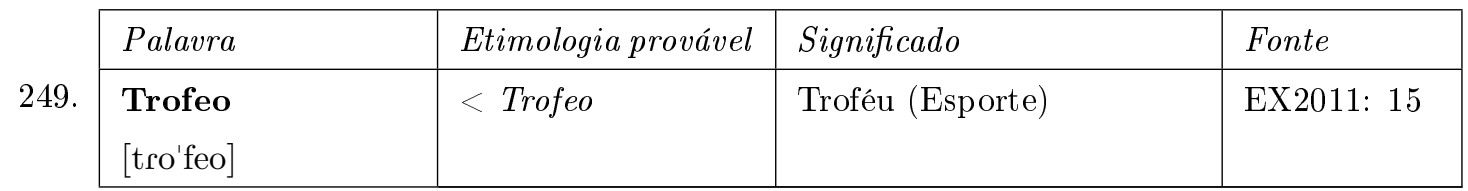

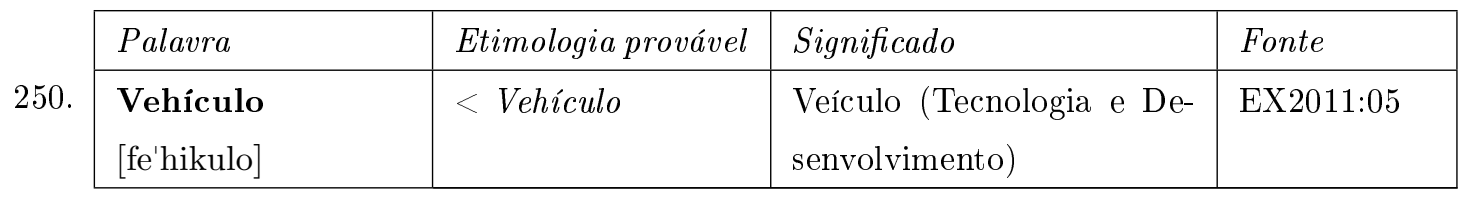

\begin{tabular}{|l|l|l|l|}
\hline 251. & Etimologia provável & Significado & Fonte \\
\cline { 2 - 5 } & $\begin{array}{l}\text { Votashon } \\
\text { [fota'fõ }]\end{array}$ & Votação (Política) & EX2011:06 \\
\hline
\end{tabular}

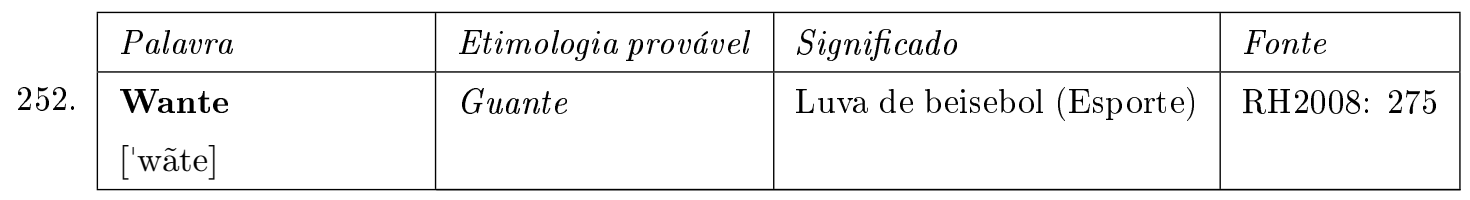

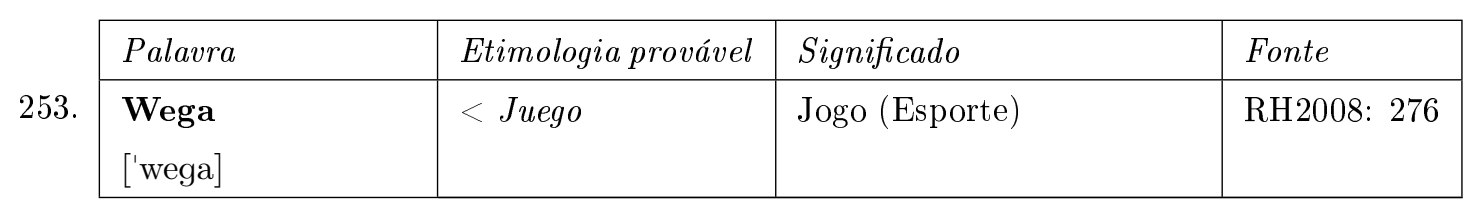

\section{HOLANDÊS}

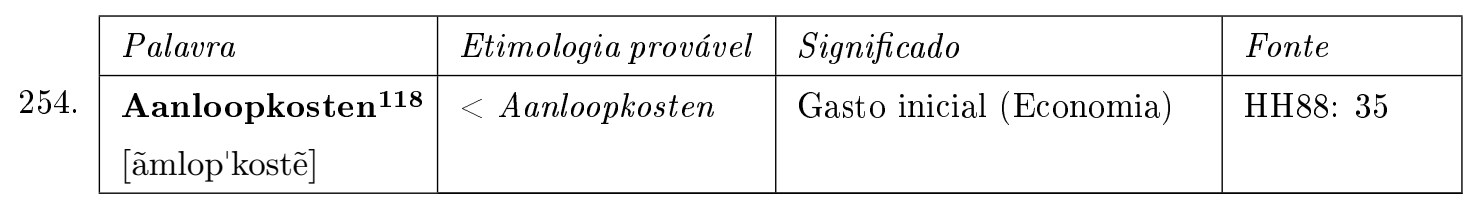

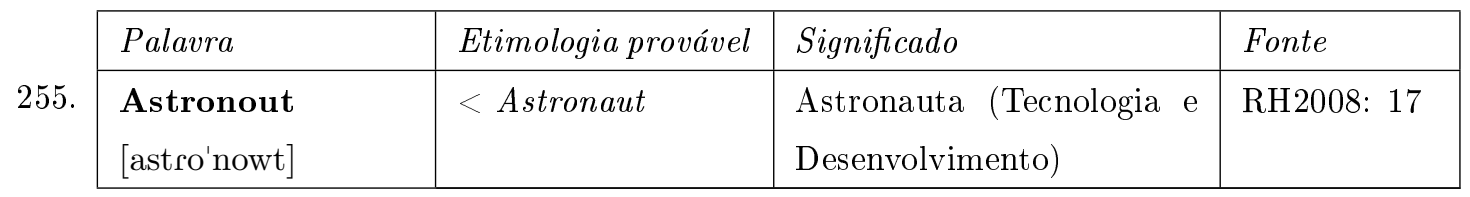

118 Varia com gastu inisial $_{642}$. 


\begin{tabular}{|c|c|c|c|c|}
\hline \multirow[b]{2}{*}{256.} & Palavra & Etimologia provável & Significado & Fonte \\
\hline & $\begin{array}{l}\text { Atombòm } 119 \\
\text { [a'tõbõ] }\end{array}$ & $<$ Atoombom & $\begin{array}{l}\text { Bomba atômica (Tecnolo- } \\
\text { gia e Desenvolvimento) }\end{array}$ & RH2008: 18 \\
\hline \multirow[b]{2}{*}{257.} & Palavra & Etimologia provável & Significado & Fonte \\
\hline & $\begin{array}{l}\text { Balk } \\
\text { ['bałk] }\end{array}$ & $<$ Balk & $\begin{array}{l}\text { Movimento ilegal cometido } \\
\text { pelo lançador (Esporte) }\end{array}$ & D86: 163 \\
\hline \multirow[b]{2}{*}{258.} & Palavra & Etimologia provável & Significado & Fonte \\
\hline & $\begin{array}{l}\text { Bankrut } \\
\text { [bã'krut] }\end{array}$ & $<$ Bankroet & $\begin{array}{l}\text { Falido, arruinado (Econo- } \\
\text { mia) }\end{array}$ & RH2008: 23 \\
\hline \multirow[b]{2}{*}{259 . } & Palavra & Etimologia provável & Significado & Fonte \\
\hline & $\begin{array}{l}\text { Bankrut } \\
\text { ['bãkrut] }\end{array}$ & $<$ Bankroet & Falência (Economia) & RH2008: 23 \\
\hline
\end{tabular}

\begin{tabular}{|l|l|l|l|}
\hline Palavra & Etimologia provável & Significado & Fonte \\
\hline Begeleiding & $<$ Begeleiding & Acompanhamento, desen- & HH88: 35 \\
volvimento da empresa & \\
[behe'lejdĩ $]$ & & Economia) & \\
& & & \\
\hline
\end{tabular}

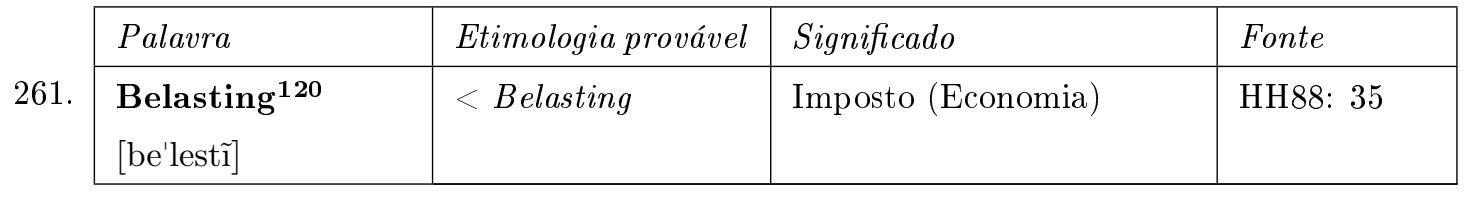

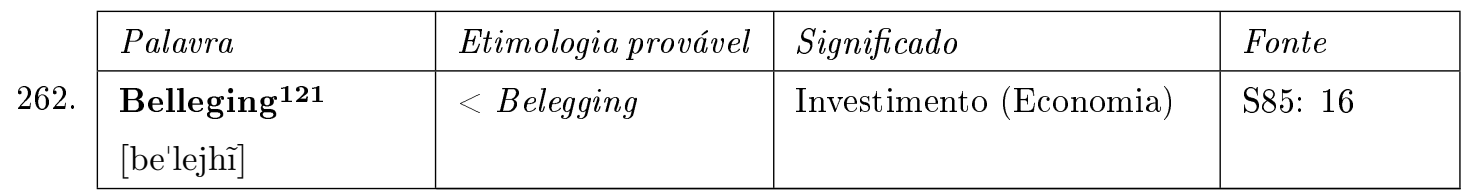

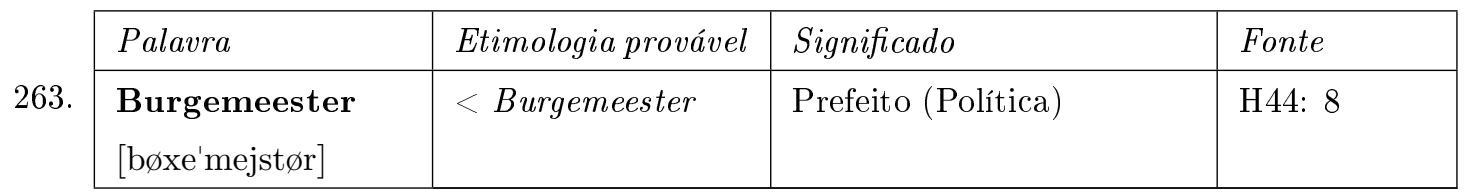

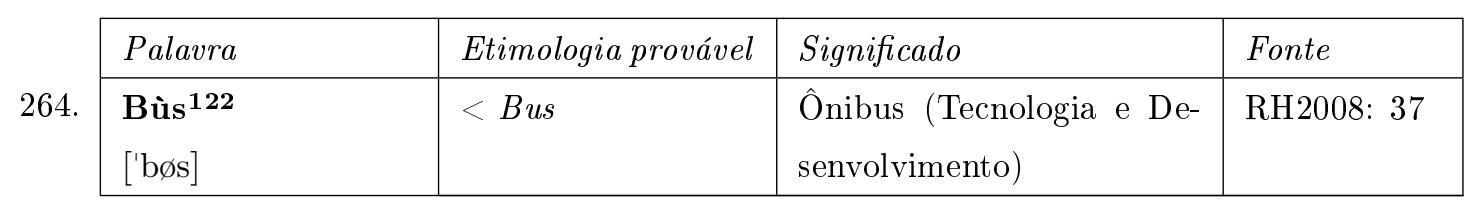

\footnotetext{
119 Varia com bòm atómiko909.

120 Varia com impuesto $_{117}$ e presupuesto $_{203}$.

121 Varia com invershon finansiero ${ }_{126}$.

122 Varia com konvoi $i_{312}$, omnibùs ${ }_{179}$, outobùs $s_{338}$.
} 


\begin{tabular}{|l|l|l|l|}
\hline Palavra & Etimologia provável & Significado & Fonte \\
\hline $\begin{array}{l}\text { Dambord } \\
\text { [dãm'bo̊t] }]\end{array}$ & $<$ Dambord & $\begin{array}{l}\text { Tabuleiro de damas (Es- } \\
\text { porte) }\end{array}$ & H44: 58 \\
& & & \\
\hline
\end{tabular}

266.

\begin{tabular}{|l|l|l|l|}
\hline Palavra & Etimologia provável & Significado & Fonte \\
\hline Dèk & $<$ Dec & Cobrir (outro jogador) & RH2008: 48 \\
['dek] & & (Esporte) & \\
& & & \\
\hline
\end{tabular}

267.

\begin{tabular}{|l|l|l|l|}
\hline Palavra & Etimologia provável & Significado & Fonte \\
\hline $\begin{array}{l}\text { Dèkmentu } \\
\text { ['dekimẽtu] }\end{array}$ & $\longleftarrow$ Dec & $\begin{array}{l}\text { Cobertura para outro joga- } \\
\text { dor (Esporte) }\end{array}$ & RH2008: 48 \\
& & & \\
\hline
\end{tabular}

268.

\begin{tabular}{|l|l|l|l|}
\hline Palavra & Etimologia provável & Significado & Fonte \\
\hline $\begin{array}{l}\text { Dinamit } \\
\text { [dina'mit] }\end{array}$ & $<$ Dynamiet & $\begin{array}{l}\text { Dinamite (Tecnologia e } \\
\text { Desenvolvimento) }\end{array}$ & RH2008: 54 \\
\hline
\end{tabular}

269.

\begin{tabular}{|l|l|l|l|}
\hline Palavra & Etimologia provável & Significado & Fonte \\
\hline $\begin{array}{l}\text { Djukupreis } \\
{[\mathrm{d} \text { zuku'prejs }]}\end{array}$ & $\longleftarrow$ Prijs & Pechincha (Economia) & RH2008: 58 \\
\hline
\end{tabular}

\begin{tabular}{|l|l|l|l|}
\hline Palavra & Etimologia provável & Significado & Fonte \\
\hline $\begin{array}{l}\text { Doelvlak } \\
\text { ['dułflak }]\end{array}$ & $<$ Doelvlak & Área-alvo (Esporte) & H44: 29 \\
\hline
\end{tabular}

271.

\begin{tabular}{|l|l|l|l|}
\hline Palavra & Etimologia provável & Significado & Fonte \\
\hline $\begin{array}{l}\text { Dribbel } \\
{[\text { 'dribet }]}\end{array}$ & $<$ Dribbel & Drible (Esporte) & H44: 13 \\
\hline
\end{tabular}

272.

\begin{tabular}{|l|l|l|l|}
\hline Palavra & Etimologia provável & Significado & Fonte \\
\hline Dugout & $<$ Dugout & Lugar reservado aos joga- & D86: 165 \\
[du'gawt $]$ & dores e técnicos das equi- & \\
& & pas nos momentos em que \\
& não estão em jogo (Es- & \\
& & \\
& & & \\
\hline
\end{tabular}

273.

\begin{tabular}{|l|l|l|l|}
\hline Palavra & Etimologia provável & Significado & Fonte \\
\hline $\begin{array}{l}\text { Elektrishèn } \\
{[\text { Elektri'fẽ }]}\end{array}$ & $<$ Elektricien & $\begin{array}{l}\text { Eletricista (Tecnologia e } \\
\text { Desenvolvimento) }\end{array}$ & RH2008: 66 \\
\hline
\end{tabular}




\begin{tabular}{|c|c|c|c|c|}
\hline \multirow[b]{2}{*}{274.} & Palavra & Etimologia provável & Significado & Fonte \\
\hline & $\begin{array}{l}\text { Elektrode } \\
{\left[\varepsilon l \varepsilon^{\prime} \text { trowd } \varepsilon\right]}\end{array}$ & $<$ Elektrode & $\begin{array}{l}\text { Elétrodo (Tecnologia e De- } \\
\text { senvolvimento) }\end{array}$ & RH2008: 66 \\
\hline \multirow[b]{2}{*}{275.} & Palavra & Etimologia provável & Significado & Fonte \\
\hline & $\begin{array}{l}\text { Elektrokardiograf } \\
\text { [Elctrokahdi'ograf] }\end{array}$ & $\begin{array}{l}<\quad \text { Elektrocardio- } \\
\text { graaf }\end{array}$ & $\begin{array}{l}\text { Eletrocardiógrafo (Tecno- } \\
\text { logia e Desenvolvimento) }\end{array}$ & RH2008: 66 \\
\hline \multirow[b]{2}{*}{276.} & Palavra & Etimologia provável & Significado & Fonte \\
\hline & $\begin{array}{l}\text { Elektrokardio- } \\
\text { gram } \\
\text { [عlctrokahdi'oxãm] }\end{array}$ & $\begin{array}{l}<\quad \text { Elektrocardio- } \\
\text { grama }\end{array}$ & $\begin{array}{l}\text { Eletrocardio-grama (Tec- } \\
\text { nologia e Desenvolvi- } \\
\text { mento) }\end{array}$ & RH2008: 66 \\
\hline & Palavra & Etimologia provável & Significado & Fonte \\
\hline 277. & $\begin{array}{l}\text { Eliograf } \\
\text { [elio'xraf] }\end{array}$ & $<$ Heliograaf & $\begin{array}{l}\text { Heliógrafo, instrumento } \\
\text { que se destina à obser- } \\
\text { vação fotográfica do Sol } \\
\text { (Tecnologia e Desenvolvi- } \\
\text { mento) }\end{array}$ & RH2008: 67 \\
\hline
\end{tabular}

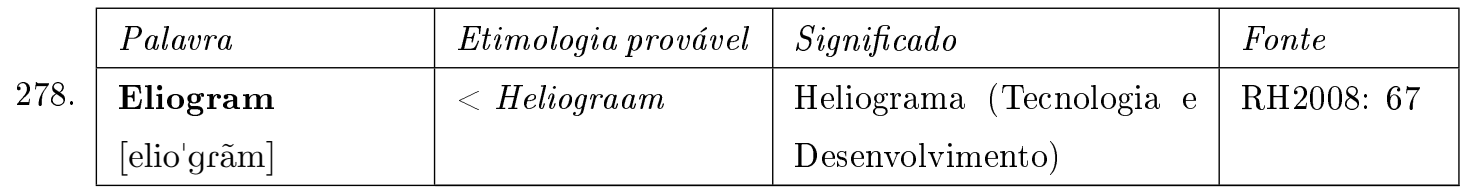

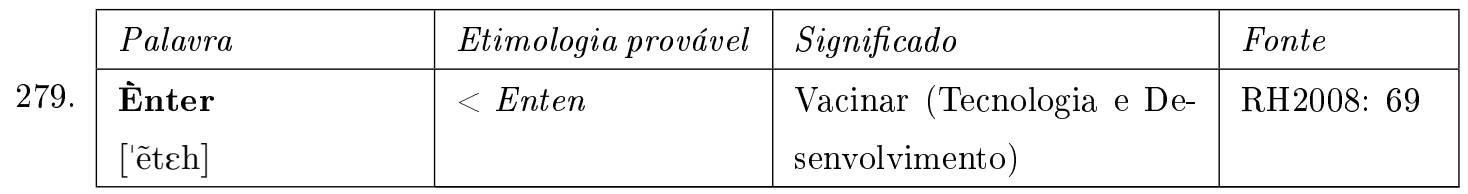

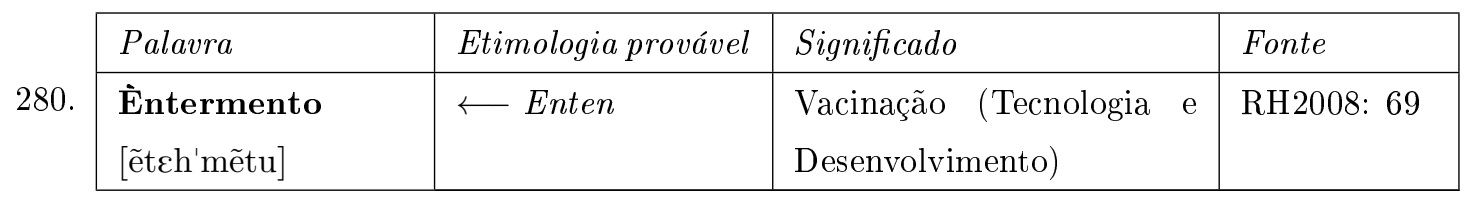

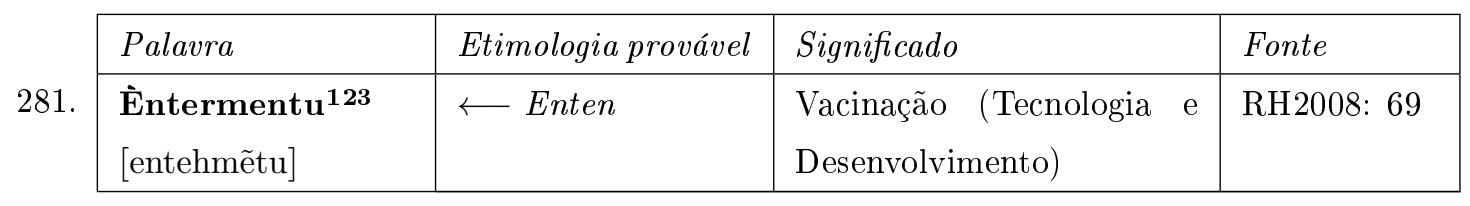

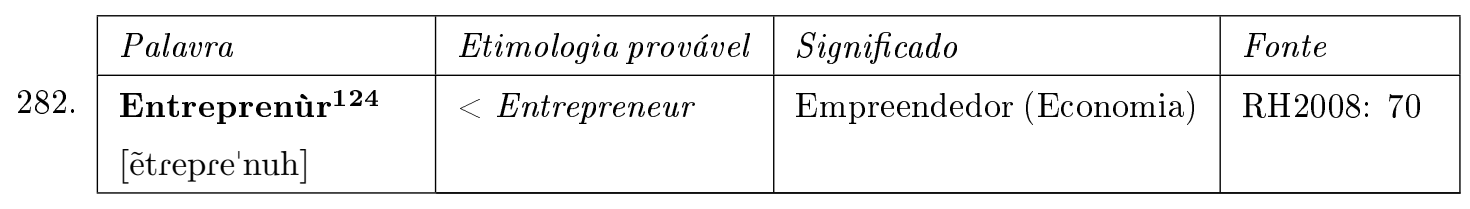

122 Varia com èntermentu $u_{281}$.

123 Varia com èntermento ${ }_{280}$.

124 Varia com emprendedó 611 e entreprenur ${ }_{282}$. $_{61}$ 


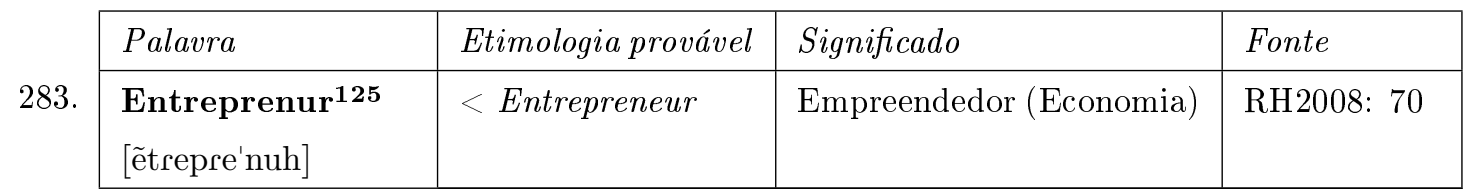

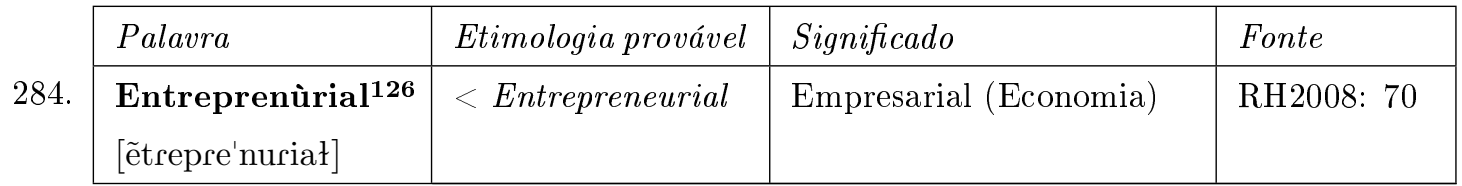

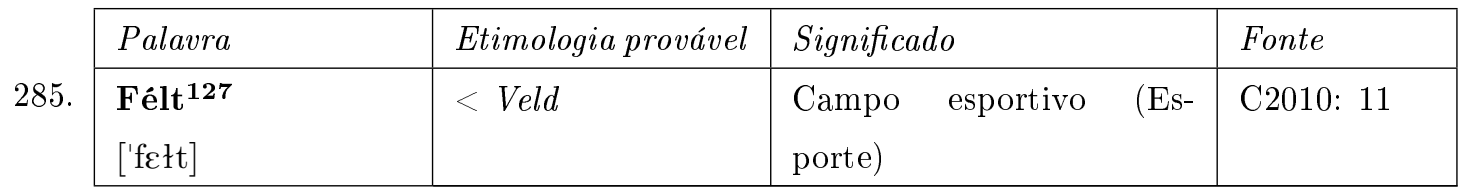

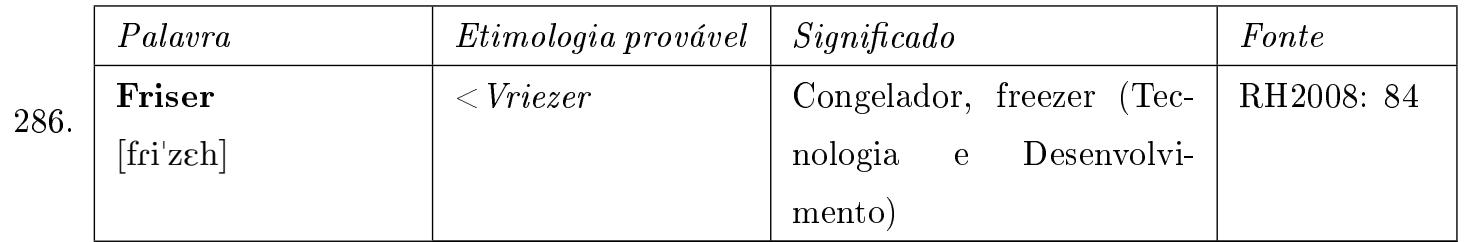

\begin{tabular}{|l|l|l|l|}
\hline 287. & Etimologia provável & Significado & Fonte \\
\cline { 2 - 5 } & $\begin{array}{l}\text { Füwèrk } \\
\text { [fy'wehk }]\end{array}$ & $\begin{array}{l}\text { Fogos de artifício (Tecnolo- } \\
\text { gia e Desenvolvimento) }\end{array}$ & RH2008: 85 \\
\hline
\end{tabular}

\begin{tabular}{|l|l|l|l|l|}
\hline 288. & Palavra & Etimologia provável & Significado & Fonte \\
\cline { 2 - 5 } & $\begin{array}{l}\text { Gasolin } \\
\text { [gaso'lin }]\end{array}$ & $\begin{array}{l}\text { Gasolina (Tecnologia e De- } \\
\text { senvolvimento) }\end{array}$ & RH2008: 88 \\
\hline
\end{tabular}

\begin{tabular}{|c|c|c|c|c|}
\hline & Palavra & Etimologia provável & Significado & Fonte \\
\hline 289. & $\begin{array}{l}\text { Gemnastik }^{\mathbf{1 2 9}} \\
{[\text { himinas'tik] }}\end{array}$ & $<$ Gymnastiek & Ginástica (Esporte) & RH2008: 88 \\
\hline
\end{tabular}

\begin{tabular}{|c|c|c|c|c|}
\hline & Palavra & Etimologia provável & Significado & Fonte \\
\hline 290. & $\begin{array}{l}\text { Gemnastiksal } \\
{[\text { himinas'tiksał }]}\end{array}$ & $<$ Gymnastiekzaal & Sala de ginástica (Esporte) & RH2008: 88 \\
\hline
\end{tabular}

291. \begin{tabular}{|l|l|l|l|}
\hline Palavra & Etimologia provável & Significado & Fonte \\
\hline Geplaatst kapi- & $<$ Geplaatst kapi- & Capital emitido (Econo- & HH88: 35 \\
taal & taal $\varnothing^{\prime}$ platfist] \\
[kapi'tał $]$ & & & \\
\hline
\end{tabular}

\footnotetext{
125 Varia com emprendedó 611 e entreprenur 282 .

126 Varia com empresarial 614 .

127 Varia com vèlt 398 .

128 Varia com fuego artifisial 100 .

129 Varia com Gimnasia ${ }_{104}$.
} 


\begin{tabular}{|l|l|l|l|}
\hline 292. & Etimologia provável & Significado & Fonte \\
\hline $\begin{array}{l}\text { Gestort kapi- } \\
\text { taal }{ }^{\mathbf{1 3 0}} \\
{[\text { hes'toht] [kapi'tał] }}\end{array}$ & $<$ Gestort kapitaal & $\begin{array}{l}\text { Capital social integrali- } \\
\text { zado (Economia) }\end{array}$ & HH88: 35 \\
\hline
\end{tabular}

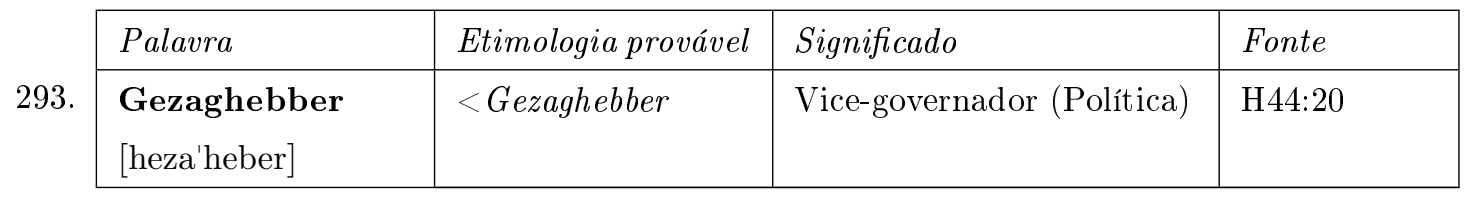

\begin{tabular}{|c|c|c|c|}
\hline Palavra & Etimologia provável & Significado & Fonte \\
\hline $\begin{array}{l}\text { 294. } \text { Glòf }^{\mathbf{1 3 1}} \\
{[\text { 'glof }]}\end{array}$ & $<$ Glove & Luva de beisebol (Esporte) & RH2008: 90 \\
\hline
\end{tabular}

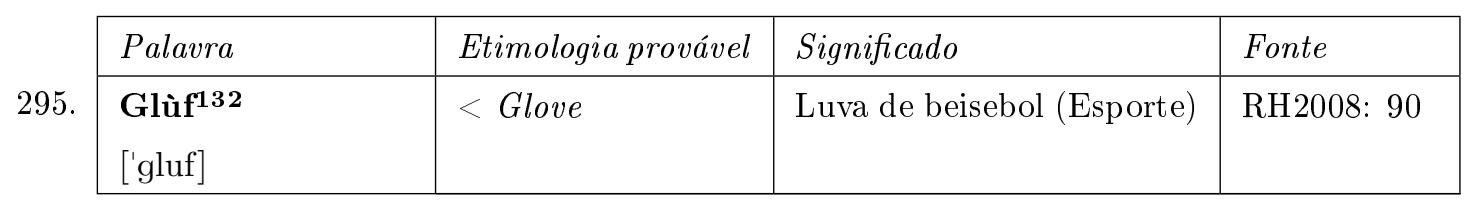

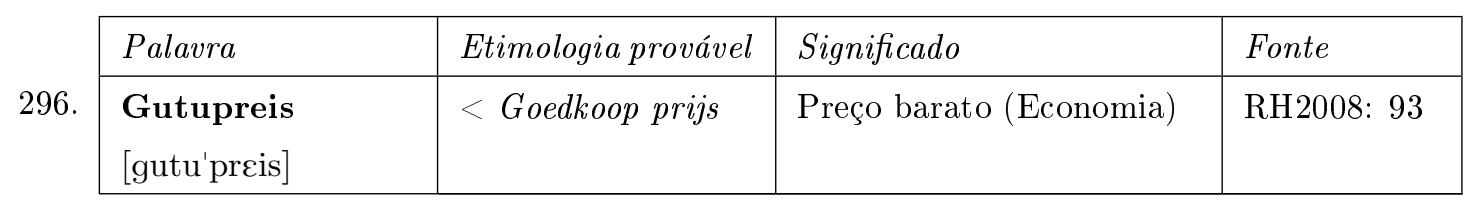

\begin{tabular}{|l|l|l|l|}
\hline Palavra & Etimologia provável & Significado & Fonte \\
\cline { 2 - 4 } & $\begin{array}{l}\text { Handbal } \\
{[\text { 'xãtbał }]}\end{array}$ & Handebol (Esporte) & P92: 25 \\
\hline
\end{tabular}

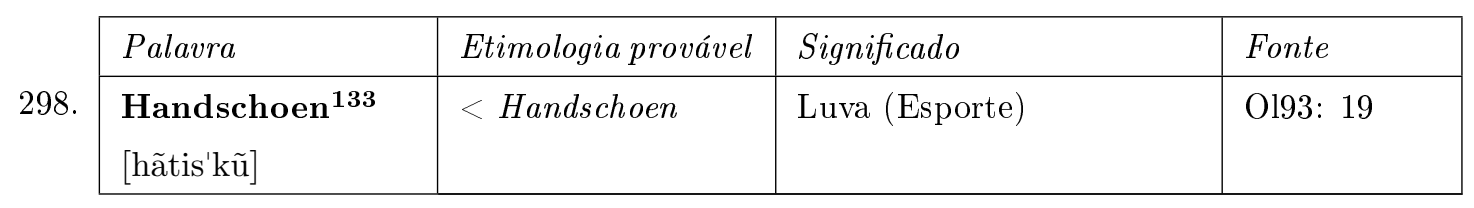

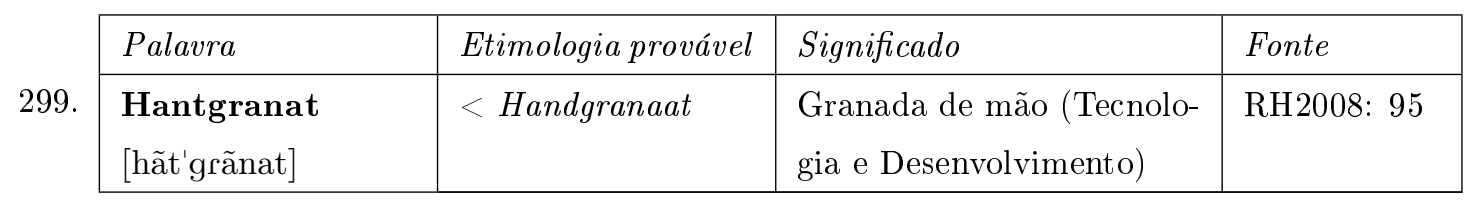

\begin{tabular}{|l|l|l|l|}
\hline Palavra & Etimologia provável & Significado & Fonte \\
\hline 300. & $\begin{array}{l}\text { Helikòpter } \\
\text { [heli'kopteh] }\end{array}$ & $\begin{array}{l}\text { Helicóptero (Tecnologia e } \\
\text { Desenvolvimento) }\end{array}$ & EX2011: 03 \\
\hline
\end{tabular}

\footnotetext{
130 Varia com kapital pagá ${ }_{674}$.

131 Varia com glùf ${ }_{295}$ e handschoen ${ }_{298}$.

132 Varia com glòf ${ }_{294}$ e handschoen $n_{298}$.

133 Varia com glòf ${ }_{294}$ e glùf ${ }_{295}$.
} 


\begin{tabular}{|c|c|c|c|}
\hline Palavra & Etimologia provável & Significado & Fonte \\
\hline $\begin{array}{l}\text { Home run } \\
\text { [hõwm'rən] }\end{array}$ & $<$ Home run & $\begin{array}{l}\text { Batimento legal para além } \\
\text { dos limites e vedações do } \\
\text { campo de jogo (no corredor } \\
\text { limitado pelas linhas que } \\
\text { partem de casa e passam } \\
\text { pela } 1^{\text {a }} \text { e } 3^{\text {a }} \text { base) que per- } \\
\text { mite ao batedor dar uma } \\
\text { volta completa, marcando } \\
\text { assim um ponto, e que to- } \\
\text { dos os corredores que es- } \\
\text { tejam em base marquem } \\
\text { ponto, sem que a defesa } \\
\text { possa fazer algo para o evi- } \\
\text { tar. (Beisebol) (Esporte) }\end{array}$ & D86: 168 \\
\hline
\end{tabular}

\begin{tabular}{|c|c|c|c|}
\hline Palavra & Etimologia provável & Significado & Fonte \\
\hline $\begin{array}{l}\text { Hómrùn } \\
\text { [hõwm'r }{ }^{\mathbf{1 3 5}} \text { ] }\end{array}$ & $<$ Home run & $\begin{array}{l}\text { Batimento legal para além } \\
\text { dos limites e vedações do } \\
\text { campo de jogo (no corredor } \\
\text { limitado pelas linhas que } \\
\text { partem de casa e passam } \\
\text { pela } 1^{\text {a }} \text { e } 3^{\text {a }} \text { base) que per- } \\
\text { mite ao batedor dar uma } \\
\text { volta completa, marcando } \\
\text { assim um ponto, e que to- } \\
\text { dos os corredores que es- } \\
\text { tejam em base marquem } \\
\text { ponto, sem que a defesa } \\
\text { possa fazer algo para o evi- } \\
\text { tar. (Beisebol) (Esporte) }\end{array}$ & RH2008: 100 \\
\hline
\end{tabular}

303.

\begin{tabular}{|c|c|c|c|}
\hline Palavra & Etimologia provável & Significado & Fonte \\
\hline $\begin{array}{l}\text { Inkomstenbelas- } \\
\text { ting } \\
\text { [ĩkõstẽbe'lestĩ] }\end{array}$ & $\begin{array}{l}<\text { Inkomstenbelas- } \\
\text { ting }\end{array}$ & $\begin{array}{l}\text { Imposto de renda (Econo- } \\
\text { mia) }\end{array}$ & RH2008: 109 \\
\hline
\end{tabular}

134 Varia com Hómrùn ${ }_{302}$.

135 Varia com Home run ${ }_{301}$. 


\begin{tabular}{|l|l|l|l|}
\hline Palavra & Etimologia provável & Significado & Fonte \\
\hline $\begin{array}{l}\text { Inventariszake- } \\
\text { ring136 } \\
\text { [ifẽtaris'zejkerĩ }]\end{array}$ & $<$ Inventariszake- & $\begin{array}{l}\text { Seguro de inventário (Eco- } \\
\text { nomia) }\end{array}$ & HH88: 22 \\
\hline
\end{tabular}

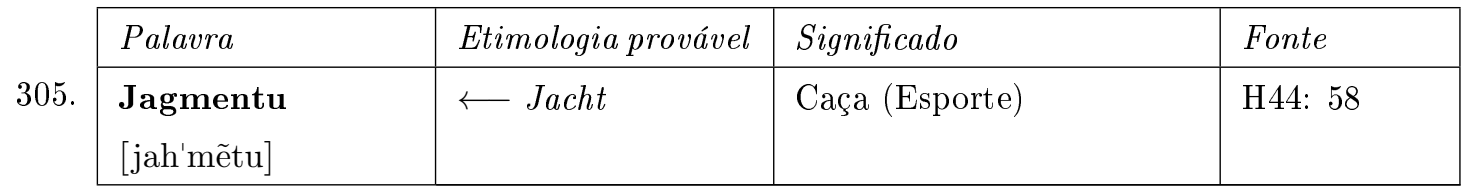

\begin{tabular}{|c|c|c|c|c|}
\hline \multirow[b]{2}{*}{306.} & Palavra & Etimologia provável & Significado & Fonte \\
\hline & $\begin{array}{l}\text { Karchi hel } \\
\text { ['kahtji] ['heł] }\end{array}$ & $<$ Gele kaart & $\begin{array}{l}\text { Cartão amarelo (futebol) } \\
\text { (Esporte) }\end{array}$ & C2010: 17 \\
\hline \multirow[b]{2}{*}{307.} & Palavra & Etimologia provável & Significado & Fonte \\
\hline & $\begin{array}{l}\text { Kegel }^{137} \\
\text { ['keheł] }\end{array}$ & $<$ Kegel & Boliche (Esporte) & RH2008: 126 \\
\hline
\end{tabular}

\begin{tabular}{|c|c|c|c|c|}
\hline & Palavra & Etimologia provável & Significado & Fonte \\
\hline 308. & $\begin{array}{l}\text { Kegelban } \\
\text { [keheł'bã] }\end{array}$ & $<$ Kegelbaan & Pino de boliche (Esporte) & RH2008: 126 \\
\hline
\end{tabular}

\begin{tabular}{|c|c|c|c|c|}
\hline & Palavra & Etimologia provável & Significado & Fonte \\
\hline 309. & $\begin{array}{l}\text { Kerosin } \\
{\left[\mathrm{k \varepsilon r}^{\prime} \mathrm{z} \tilde{1}\right]}\end{array}$ & $<$ Kerosine & $\begin{array}{l}\text { Querosene (Tecnologia e } \\
\text { Desenvolvimento) }\end{array}$ & RH2008: 127 \\
\hline
\end{tabular}

\begin{tabular}{|l|l|l|l|}
\hline Palavra & Etimologia provável & Significado & Fonte \\
\cline { 2 - 4 } & $\begin{array}{l}\text { Klavier } \\
\text { [38 } \\
\text { [klafi'eh] }\end{array}$ & $\begin{array}{l}\text { Teclado (Tecnologia e De- } \\
\text { senvolvimento) }\end{array}$ & RH2008: 254 \\
\hline
\end{tabular}

\begin{tabular}{|l|l|l|l|}
\hline Palavra & Etimologia provável & Significado & Fonte \\
\hline Knòpwerk & $<$ Knop / Werk & Computadores interliga- & RH2008: 130 \\
[kenop'wehk $]$ & & $\begin{array}{l}\text { dos, rede (Tecnologia e } \\
\text { Desenvolvimento) }\end{array}$ & \\
& & & \\
\hline
\end{tabular}

\begin{tabular}{|l|l|l|l|}
\hline Palavra & Etimologia provável & Significado & Fonte \\
\hline Konvoi ${ }^{139}$ & $<$ Konvooi & Onibus (Tecnologia e De- & RH2008: \\
{$[\mathrm{kõ}$ 'foi $]$} & & senvolvimento) & 139 \\
& & & \\
\hline
\end{tabular}

\footnotetext{
136 Varia com seguro di inventario ${ }_{819}$.

137 Varia com bowling 920 .

138 Varia com teklado ${ }_{847}$.

139 Varia com bùs ${ }_{264}$, omnibùs ${ }_{179}$, outobùs $s_{338}$.
} 


\begin{tabular}{|l|l|l|l|}
\hline Palavra & Etimologia provável & Significado & Fonte \\
\hline $\begin{array}{l}\text { Korant }^{\mathbf{1 4 0}} \\
\text { [ko'sãt] }\end{array}$ & $<$ Krant & $\begin{array}{l}\text { Jornal (Tecnologia e De- } \\
\text { senvolvimento) }\end{array}$ & RH2008: \\
& & & \\
\hline
\end{tabular}

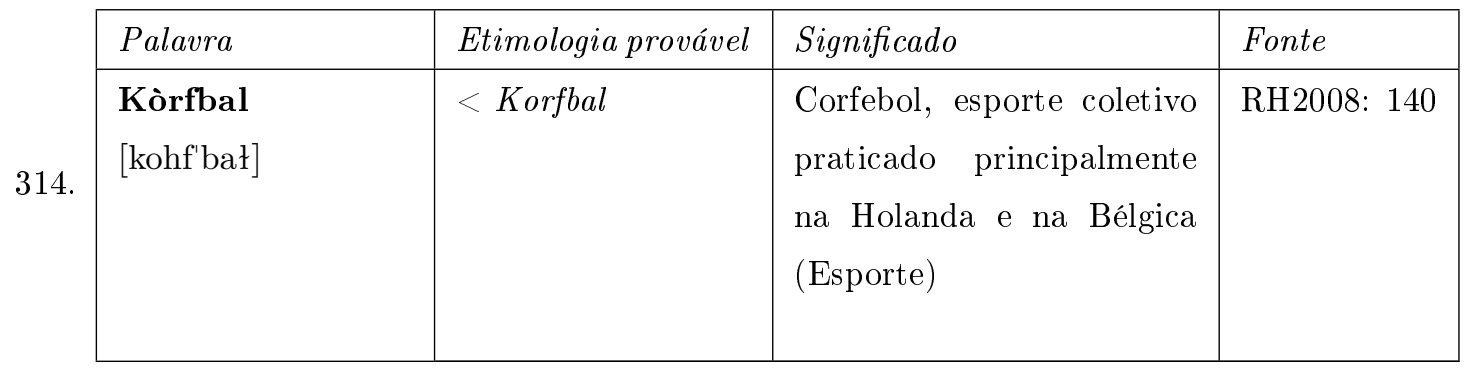

\begin{tabular}{|l|l|l|l|}
\hline Palavra & Etimologia provável & Significado & Fonte \\
\cline { 2 - 5 } & $\begin{array}{l}\text { Korosin } \\
{[\text { koro'zĩ }]}\end{array}$ & $\begin{array}{l}\text { Querosene (Tecnologia e } \\
\text { Desenvolvimento) }\end{array}$ & RH2008: 127 \\
\hline
\end{tabular}

\begin{tabular}{|c|c|c|c|}
\hline Palavra & Etimologia provável & Significado & Fonte \\
\hline \begin{tabular}{l|l}
316. & Laglaufen \\
& [laglaw'fã]
\end{tabular} & $<$ Langlaufen & Esqui (Esporte) & P92: 48 \\
\hline
\end{tabular}

\begin{tabular}{|l|l|l|l|}
\hline Palavra & Etimologia provável & Significado & Fonte \\
\hline $\begin{array}{l}\text { Liquide midde- } \\
\text { len'141 }\end{array}$ & $<$ Liquide middelen & $\begin{array}{l}\text { Capital líquido (Econo- } \\
\text { mia) } \\
\text { [li'kide] ['midelẽ] }\end{array}$ & HH88: 40 \\
\hline
\end{tabular}

\begin{tabular}{|c|c|c|c|c|}
\hline & Palavra & Etimologia provável & Significado & Fonte \\
\hline 318. & $\begin{array}{l}\text { Liquiditeit }^{\mathbf{1 4 2}} \\
\text { [liki'tejt] }\end{array}$ & $<$ Liquiditeit & Liquidez (Economia) & HH88: 37 \\
\hline
\end{tabular}

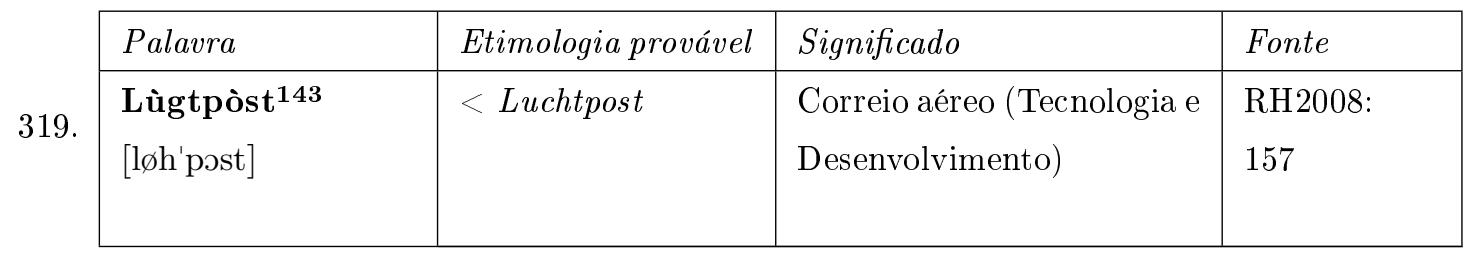

\footnotetext{
140 Varia com periódiko 187.

141 Varia com kapital likido $o_{673}$.

142 Varia com likides $_{157}$.

143 Varia com pòst aéreo 916 .
} 


\begin{tabular}{|l|l|l|l|}
\hline Palavra & Etimologia provável & Significado & Fonte \\
\hline Maatschappelijk & $<$ Maatschappelijk & Capital social (Economia) & HH88: 40 \\
kapitaal144 & kapitaal & & \\
[matJis'xapelik] & & & \\
{$[$ kapi'tał $]$} & & & \\
\hline
\end{tabular}

321.

\begin{tabular}{|l|l|l|l|}
\hline Palavra & Etimologia provável & Significado & Fonte \\
\hline $\begin{array}{l}\text { Mashin } \\
{[\text { ma' } \tilde{1}]}\end{array}$ & $<$ Machine & Máquina (Tecnologia e De- & RH2008: \\
& & senvolvimento) & 163 \\
\hline
\end{tabular}

322.

\begin{tabular}{|l|l|l|l|}
\hline Palavra & Etimologia provável & Significado & Fonte \\
\hline $\begin{array}{l}\text { Mashin di bora } \\
\text { [ma'[ĩ] [di] ['bora] }\end{array}$ & $\Leftarrow$ Boormachine & Máquina, broca (Tecnolo- & RH2008: \\
& & gia e Desenvolvimento) & 163 \\
\hline
\end{tabular}

323.

\begin{tabular}{|l|l|l|l|}
\hline Palavra & Etimologia provável & Significado & Fonte \\
\hline $\begin{array}{l}\text { Mashin di kopia } \\
{[\mathrm{ma}[\tilde{1}][\mathrm{di}][\text { ['kopia] }}\end{array}$ & $\Leftarrow$ Kopieermachine & Mimeógrafo (Tecnologia e & RH2008: \\
\hline
\end{tabular}

324.

\begin{tabular}{|l|l|l|l|}
\hline Palavra & Etimologia provável & Significado & Fonte \\
\hline $\begin{array}{l}\text { Mashin di nit } \\
{[\text { ma' }[\tilde{1}][\mathrm{di}][\text { [nit] }}\end{array}$ & $\Leftarrow$ Nietmachine & Grampeador (Tecnologia e & RH2008: \\
& & Desenvolvimento) & 163 \\
\hline
\end{tabular}

325.

\begin{tabular}{|l|l|l|l|}
\hline Palavra & Etimologia provável & Significado & Fonte \\
\hline Mashin di stènsil & $\Leftarrow$ Stencilmachine & Mimeógrafo (Tecnologia e & RH2008: \\
[ma'fĩ] [di] [is'tẽsił] & & Desenvolvimento) & 167 \\
& & & \\
\hline
\end{tabular}

\begin{tabular}{|c|c|c|c|}
\hline Palavra & Etimologia provável & Significado & Fonte \\
\hline \begin{tabular}{ll}
\cline { 2 - 2 } 326. & Mashin di taip \\
[ma' $\left.\int \tilde{1}\right][$ di] ['tejp]
\end{tabular} & $\Leftarrow$ Typemachine & $\begin{array}{l}\text { Máquina de escrever } \\
\text { (Tecnologia e Desenvolvi- } \\
\text { mento) }\end{array}$ & $\begin{array}{l}\text { RH2008: } \\
163\end{array}$ \\
\hline
\end{tabular}

327.

\begin{tabular}{|l|l|l|l|}
\hline Palavra & Etimologia provável & Significado & Fonte \\
\hline $\begin{array}{l}\text { Mashinal } \\
\text { [ma'finał }]\end{array}$ & $<$ Machinaal & Maquinal (Tecnologia e & RH2008: \\
& & Desenvolvimento) & 163 \\
\hline
\end{tabular}

144 Varia com kapital social 676 . 
328.

\begin{tabular}{|l|l|l|l|}
\hline Palavra & Etimologia provável & Significado & Fonte \\
\hline $\begin{array}{l}\text { Mashinalmente } \\
\text { [mafinał'mẽte] }\end{array}$ & $\longleftarrow$ Machinaal & $\begin{array}{l}\text { Maquinalmente (Tecnolo- } \\
\text { gia e Desenvolvimento) }\end{array}$ & $\begin{array}{l}\text { RH2008: } \\
\end{array}$ \\
& & & \\
\hline
\end{tabular}

329 .

\begin{tabular}{|l|l|l|l|}
\hline Palavra & Etimologia provável & Significado & Fonte \\
\hline $\begin{array}{l}\text { Mashinista } \\
\text { [ma'Jinnista] }\end{array}$ & $<$ Machinist & Mecânico (Tecnologia e & RH2008: \\
& & Desenvolvimento) & 163 \\
\hline
\end{tabular}

330.

\begin{tabular}{|l|l|l|l|}
\hline Palavra & Etimologia provável & Significado & Fonte \\
\hline $\begin{array}{l}\text { Masker } \\
{[\text { mas'kər }]}\end{array}$ & $<$ Masker & $\begin{array}{l}\text { Máscara (esgrima) (Es- } \\
\text { porte) }\end{array}$ & OL93: 19 \\
\hline
\end{tabular}

331.

\begin{tabular}{|l|l|l|l|}
\hline Palavra & Etimologia provável & Significado & Fonte \\
\hline $\begin{array}{l}\text { Mekanikal } \\
\text { [mekani'kat] }\end{array}$ & $<$ Machinaal & Maquinal (Tecnologia e & RH2008: \\
& & Desenvolvimento) & 165 \\
\hline
\end{tabular}

332 .

\begin{tabular}{|l|l|l|l|}
\hline Palavra & Etimologia provável & Significado & Fonte \\
\hline $\begin{array}{l}\text { Mikroskop } \\
\text { [mikros'kowp] }\end{array}$ & $<$ Microscoop & Microscópio (Tecnologia e & RH2008: \\
& & Desenvolvimento) & 167 \\
\hline
\end{tabular}

\begin{tabular}{|l|l|l|l|}
\hline Palavra & Etimologia provável & Significado & Fonte \\
\hline $\begin{array}{l}\text { Mimeograf } \\
\text { mashin } \\
{[\text { mimew'graf }]}\end{array}$ & $<$ Mimeograaf ma- & Microscópico (Tecnologia e & RH2008: \\
{$[$ ma'fi] $]$} & chine & Desenvolvimento) & 167 \\
\hline
\end{tabular}

\begin{tabular}{|c|c|c|c|}
\hline Palavra & Etimologia provável & Significado & Fonte \\
\hline $\begin{array}{l}\text { Negatif } \\
\text { [nega'tif] }\end{array}$ & $<$ Negatief & $\begin{array}{ll}\text { Negativo } & \text { (fotografia) } \\
\text { (Tecnologia e } & \text { Desenvolvi- } \\
\text { mento) } & \end{array}$ & $\begin{array}{l}\text { RH2008: } \\
174\end{array}$ \\
\hline
\end{tabular}

335.

\begin{tabular}{|l|l|l|l|}
\hline Palavra & Etimologia provável & Significado & Fonte \\
\hline $\begin{array}{l}\text { Onspòrtif } \\
\text { [õis'pohtif] }\end{array}$ & $<$ Onsportief & Não esportivo (Esporte) & C2010: 21 \\
\hline
\end{tabular}

${ }^{145}$ Varia com mekániko ${ }_{732}$. 
336

\begin{tabular}{|l|l|l|l|}
\hline Palavra & Etimologia provável & Significado & Fonte \\
\hline $\begin{array}{l}\text { Opstalverze- } \\
\text { kering146 } \\
\text { [opistałfeh'zejkerĩ }]\end{array}$ & Opstalverzeke- & $\begin{array}{l}\text { Seguro para moradia (Eco- } \\
\text { nomia) }\end{array}$ & HH88: 22 \\
\hline
\end{tabular}

337.

\begin{tabular}{|l|l|l|l|}
\hline Palavra & Etimologia provável & Significado & Fonte \\
\hline $\begin{array}{l}\text { Outo' } \\
\text { ['owto }]\end{array}$ & $<$ Auto & $\begin{array}{l}\text { Carro (Tecnologia e Desen- } \\
\text { volvimento) }\end{array}$ & RH2008: 185 \\
\hline
\end{tabular}

338.

\begin{tabular}{|l|l|l|l|}
\hline Palavra & Etimologia provável & Significado & Fonte \\
\hline $\begin{array}{l}\text { Outobùs }{ }^{\mathbf{1 4 8}} \\
\text { [owto'bøs] }\end{array}$ & $<$ Autobus & $\begin{array}{l}\text { Onibus (Tecnologia e De- } \\
\text { senvolvimento) }\end{array}$ & $\begin{array}{l}\text { RH2008: } \\
185\end{array}$ \\
\hline
\end{tabular}

339.

\begin{tabular}{|l|l|l|l|}
\hline Palavra & Etimologia provável & Significado & Fonte \\
\hline $\begin{array}{l}\text { Outomobil } \\
\text { [owtomo'bił }]\end{array}$ & $<$ Automobiel & Automóvel (Tecnologia e & RH2008: \\
& & Desenvolvimento) & 185 \\
\hline
\end{tabular}

340.

\begin{tabular}{|l|l|l|l|}
\hline Palavra & Etimologia provável & Significado & Fonte \\
\hline $\begin{array}{l}\text { Parker } \\
\text { [pah'keh] }\end{array}$ & $<$ Parkeren & Estacionar (Tecnologia e & RH2008: \\
& & Desenvolvimento) & 245 \\
\hline
\end{tabular}

341.

\begin{tabular}{|l|l|l|l|}
\hline Palavra & Etimologia provável & Significado & Fonte \\
\hline $\begin{array}{l}\text { Pasport } \\
\text { [pas'poh] }\end{array}$ & $<$ Paspoort & Passaporte (Tecnologia e & RH2008: \\
& & Desenvolvimento) & 245 \\
\hline
\end{tabular}

342.

\begin{tabular}{|l|l|l|l|}
\hline Palavra & Etimologia provável & Significado & Fonte \\
\hline $\begin{array}{l}\text { Pele }^{\mathbf{1 5 0}} \\
\text { ['pele] }\end{array}$ & $<$ Spel & $\begin{array}{l}\text { Tipo de jogo como amare- } \\
\text { linha (Esporte) }\end{array}$ & RH2008: 194 \\
& & \\
\hline
\end{tabular}

146 Varia com seguro di edifisio ${ }_{818}$.

147 Varia com outomobil ${ }_{339}$.

148 Varia com bùs ${ }_{264}$, omnibùs ${ }_{179}$, konvoi $_{312}$.

149 Varia com outo 337 .

150 Varia com $d j u l_{940}$. 
343.

\begin{tabular}{|l|l|l|l|}
\hline Palavra & Etimologia provável & Significado & Fonte \\
\hline $\begin{array}{l}\text { Pilot } \\
\text { [pi'lot }]\end{array}$ & $<$ Piloot & $\begin{array}{l}\text { Piloto (Tecnologia e De- } \\
\text { senvolvimento) }\end{array}$ & RH2008: 198 \\
& & & \\
\hline
\end{tabular}

344.

\begin{tabular}{|l|l|l|l|}
\hline Palavra & Etimologia provável & Significado & Fonte \\
\hline Pòmp & $<$ Pomp & Bombear (Tecnologia e De- & RH2008: \\
['põp] & & senvolvimento) & 88 \\
& & & \\
\hline
\end{tabular}

345.

\begin{tabular}{|l|l|l|l|}
\hline Palavra & Etimologia provável & Significado & Fonte \\
\hline Pòst & $<$ Post & Correio (Tecnologia e De- & RH2008: \\
['post] & & senvolvimento) & 203 \\
& & & \\
\hline
\end{tabular}

346.

\begin{tabular}{|l|l|l|l|}
\hline Palavra & Etimologia provável & Significado & Fonte \\
\hline Pòst & $<$ Post & $\begin{array}{l}\text { Enviar, remeter (Tecnolo- } \\
\text { ['post] }\end{array}$ & RH2008: \\
& & & 203 \\
\hline
\end{tabular}

347.

\begin{tabular}{|l|l|l|l|}
\hline Palavra & Etimologia provável & Significado & Fonte \\
\hline $\begin{array}{l}\text { Pòstbòks } \\
\text { [post'bokis] }\end{array}$ & $<$ Postbus & $\begin{array}{l}\text { Caixa de correio (Tecnolo- } \\
\text { gia e Desenvolvimento) }\end{array}$ & $\begin{array}{l}\text { RH2008: } \\
\end{array}$ \\
& & & \\
\hline
\end{tabular}

348.

\begin{tabular}{|l|l|l|l|}
\hline Palavra & Etimologia provável & Significado & Fonte \\
\hline $\begin{array}{l}\text { Preis } \\
\text { ['prejs }]\end{array}$ & $<$ Prijs & Preço (Economia) & EX2011: 11 \\
\hline
\end{tabular}

349.

\begin{tabular}{|l|l|l|l|}
\hline Palavra & Etimologia provável & Significado & Fonte \\
\hline Radiogram & $<$ Radiogram & Radiograma (Tecnologia e & RH2008: \\
[xadio'gram] & & Desenvolvimento) & 212 \\
& & & \\
\hline
\end{tabular}

350.

\begin{tabular}{|l|l|l|l|}
\hline Palavra & Etimologia provável & Significado & Fonte \\
\hline Radjeter & $<$ Radiateur & Radiador (Tecnologia e & RH2008: \\
[xadzi'ejte $]$ & & Desenvolvimento) & 212 \\
& & & \\
\hline
\end{tabular}

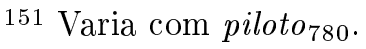

152 Varia com preshon $_{200}$. 


\begin{tabular}{|l|l|l|l|}
\hline Palavra & Etimologia provável & Significado & Fonte \\
\hline Rafinaderia & $<$ Rafinaderij & Refinaria (Tecnologia e De- & RH2008: \\
[xafinade'ria] & senvolvimento) & 57 \\
\hline
\end{tabular}

\begin{tabular}{|c|c|c|c|c|}
\hline & Palavra & Etimologia provável & Significado & Fonte \\
\hline 352 . & $\begin{array}{l}\text { Rentabiliteit }^{\mathbf{1 5 3}} \\
\text { [rẽtabili'tejt] }\end{array}$ & $<$ Rentabiliteit & Rendimento (Economia) & HH88: 31 \\
\hline
\end{tabular}

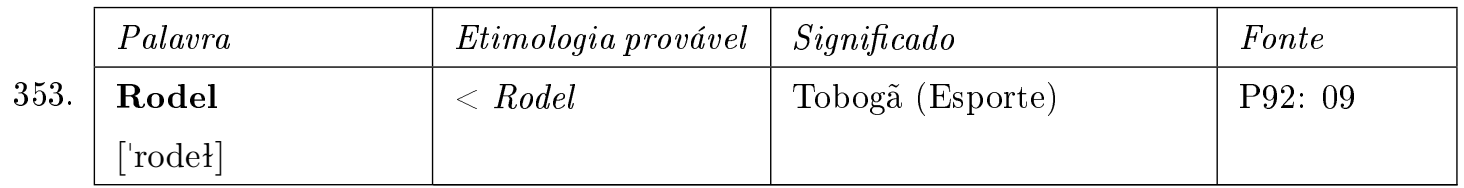

\begin{tabular}{|c|c|c|c|c|}
\hline & Palavra & Etimologia provável & Significado & Fonte \\
\hline 354. & $\begin{array}{l}\text { Ròlskats } \\
\text { [rołis'katis] }\end{array}$ & $<$ Rolschaatsen & Patins de rodas (Esporte) & P92: 09 \\
\hline
\end{tabular}

\begin{tabular}{|c|c|c|c|c|}
\hline & Palavra & Etimologia provável & Significado & Fonte \\
\hline 355. & $\begin{array}{l}\text { Rònt } \\
\text { ['rõt] }\end{array}$ & $<$ Rond & Round (Esporte) & EX2011: 17 \\
\hline
\end{tabular}

\begin{tabular}{|l|l|l|l|}
\hline Palavra & Etimologia provável & Significado & Fonte \\
\hline $\begin{array}{l}\text { Ròntgenstral } \\
\text { [xãxẽs'trał }]\end{array}$ & $<$ Röntgenstral & $\begin{array}{l}\text { Raio-x (Tecnologia e De- } \\
\text { senvolvimento) }\end{array}$ & RH2008: 65 \\
\hline
\end{tabular}

\begin{tabular}{|c|c|c|c|c|}
\hline & Palavra & Etimologia provável & Significado & Fonte \\
\hline 357. & $\begin{array}{l}\text { Rookie } \\
{\left[r{ }^{\prime} k i\right]}\end{array}$ & $<$ Rookie & $\begin{array}{l}\text { Jogador novato (beisebol) } \\
\text { (Esporte) }\end{array}$ & D86: 174 \\
\hline
\end{tabular}

\begin{tabular}{|l|l|l|l|}
\hline Palavra & Etimologia provável & Significado & Fonte \\
\cline { 2 - 4 } & $\begin{array}{l}\text { Schermbroek } \\
\text { [iskerẽm'bruk] }\end{array}$ & $\begin{array}{l}\text { Calças de tela (esgrima) } \\
\text { (Esporte) }\end{array}$ & OL93: 19 \\
\hline
\end{tabular}

\begin{tabular}{|l|l|l|l|}
\hline Palavra & Etimologia provável & Significado & Fonte \\
\hline $\begin{array}{l}\text { Schermpak } \\
\text { [iskeram'pak }]\end{array}$ & $<$ Schermpak & $\begin{array}{l}\text { Captura de tela (esgrima) } \\
\text { (Esporte) }\end{array}$ & OL93: 19 \\
\hline
\end{tabular}

153 Varia com rendimentu ${ }_{810}$

154 Varia com eksrei $i_{430}$. 
360.

\begin{tabular}{|l|l|l|l|}
\hline Palavra & Etimologia provável & Significado & Fonte \\
\hline $\begin{array}{l}\text { Schermvest } \\
\text { [iskerẽm'fest }]\end{array}$ & $<$ Schermvest & $\begin{array}{l}\text { Jaqueta (esgrima) (Es- } \\
\text { porte) }\end{array}$ & OL93: 19 \\
& & & \\
\hline
\end{tabular}

361.

\begin{tabular}{|l|l|l|l|}
\hline Palavra & Etimologia provável & Significado & Fonte \\
\hline $\begin{array}{l}\text { Screenplank } \\
\text { [iskrĩ'plãk] }\end{array}$ & $<$ Screenplak & Prancha (Esporte) & RH2008: 244 \\
\hline
\end{tabular}

\begin{tabular}{|c|c|c|c|c|}
\hline & Palavra & Etimologia provável & Significado & Fonte \\
\hline 362 & $\begin{array}{l}\text { Sèn } \\
\text { ['sẽ] }\end{array}$ & $\longleftarrow$ Cent & $\begin{array}{l}\text { Dinheiro, centavo (Econo- } \\
\text { mia) }\end{array}$ & RH2008: 231 \\
\hline
\end{tabular}

\begin{tabular}{|l|l|l|l|l|}
\hline 363. & Ealavra & $\begin{array}{l}\text { Etimologia provável } \\
\text { Shòp }\end{array}$ & Significado & Fonte \\
\hline ['Sop]
\end{tabular}

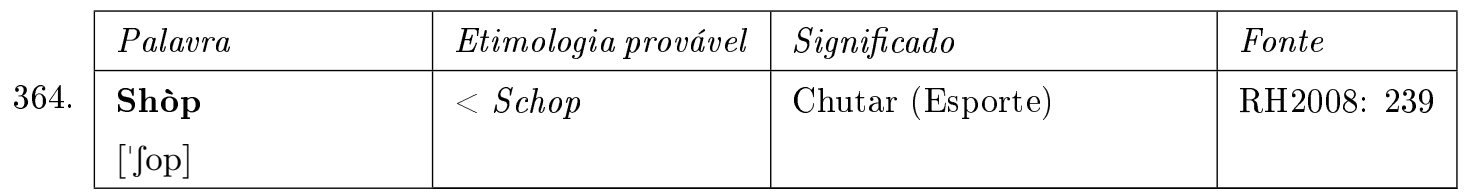

\begin{tabular}{|c|c|c|c|}
\hline Palavra & Etimologia provável & Significado & Fonte \\
\hline $\begin{array}{l}\text { Shòpmentu }{ }^{\mathbf{1 5 6}} \\
\text { [Jopi'mẽtu] }\end{array}$ & $\longleftarrow$ Schop & Chute (Esporte) & RH2008: 239 \\
\hline
\end{tabular}

\begin{tabular}{|c|c|c|c|}
\hline Palavra & Etimologia provável & Significado & Fonte \\
\hline $\begin{array}{l}\text { Skaf } \\
{[\text { 'sxaf] }}\end{array}$ & $<$ Schaaf & $\begin{array}{l}\text { Aplainar (Tecnologia e De- } \\
\text { senvolvimento) }\end{array}$ & $\begin{array}{l}\text { RH2008: } \\
238\end{array}$ \\
\hline
\end{tabular}

\begin{tabular}{|l|l|l|l|}
\hline Palavra & Etimologia provável & Significado & Fonte \\
\hline Skafdó & $\longleftarrow$ Schaaf & $\begin{array}{l}\text { Máquina de aplainar } \\
\text { (Tecnologia e Desenvolvi- } \\
\text { [sxaf'do }]\end{array}$ & $\begin{array}{l}\text { RH2008: } \\
\text { mento) }\end{array}$ \\
& & & \\
\hline
\end{tabular}

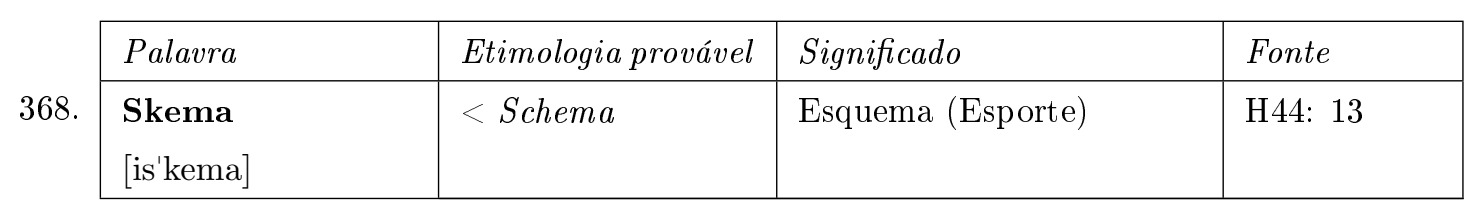

155 Varia com shòpmentu ${ }_{365}$.

156 Varia com shòp 363 . 


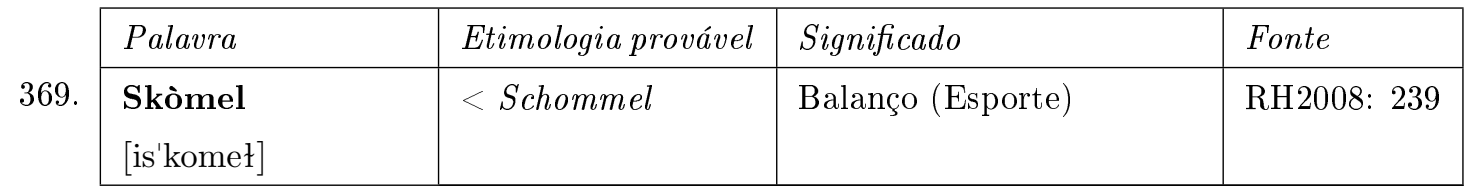

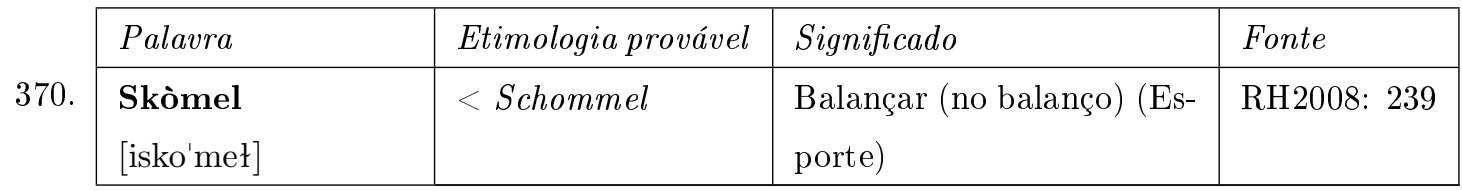

\begin{tabular}{|l|l|l|l|}
\hline Palavra & Etimologia provável & Significado & Fonte \\
\hline Skref ${ }^{157}$ & $<$ Schrift & Computador (Tecnologia e & RH2008: \\
[is'kref $]$ & & Desenvolvimento) & 239 \\
& & & \\
\hline
\end{tabular}

\begin{tabular}{|c|c|c|c|c|}
\hline & Palavra & Etimologia provável & Significado & Fonte \\
\hline 372. & $\begin{array}{l}\text { Snòrkel } \\
\text { [is'nohkeł] }\end{array}$ & $<$ Snorkel & $\begin{array}{l}\text { Respirador (de mergulha- } \\
\text { dor) (Esporte) }\end{array}$ & RH2008: 241 \\
\hline
\end{tabular}

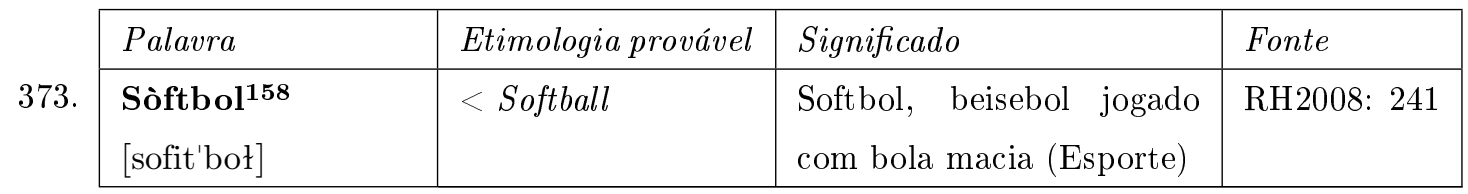

\begin{tabular}{|c|c|c|c|}
\hline Palavra & Etimologia provável & Significado & Fonte \\
\hline $\begin{array}{l}\text { Solvabiliteit }{ }^{159} \\
\text { [sol'fabilitejt] }\end{array}$ & $<$ Solvabiliteit & Solvência (Economia) & HH88: 35 \\
\hline
\end{tabular}

\begin{tabular}{|c|c|c|c|}
\hline Palavra & Etimologia provável & Significado & Fonte \\
\hline $\begin{array}{l}\text { Spar }^{160} \\
\text { [is'pah] }\end{array}$ & $<$ Spaar & Poupar (Economia) & RH2008: 243 \\
\hline
\end{tabular}

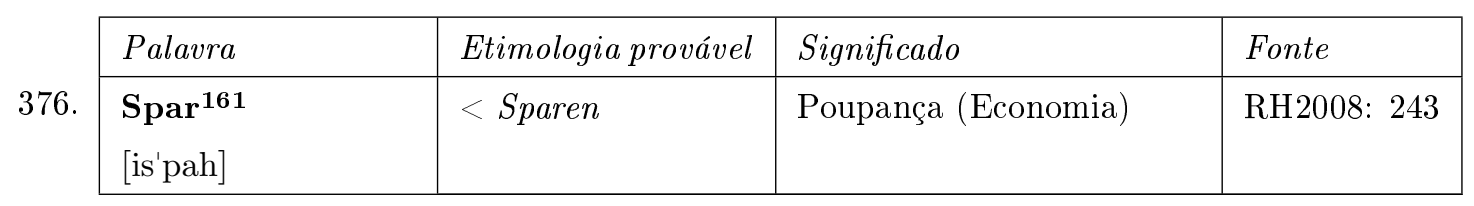

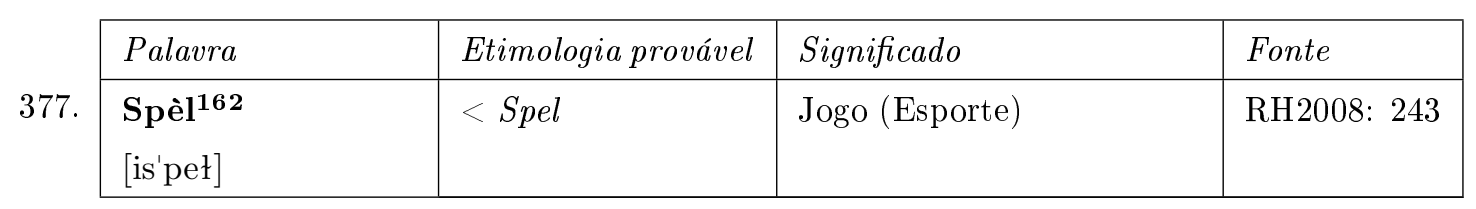

157 Varia com kompiuter 474 .

158 Varia com sòfbol ${ }_{230}$.

159 Varia com solvensia $a_{836}$.

160 Varia com ahorá ${ }_{7}$ e kremenchá $a_{710}$.

${ }_{161}$ Varia com sam $_{953}$ e ahoro.

162 Varia com hungamentu $u_{114}$. 


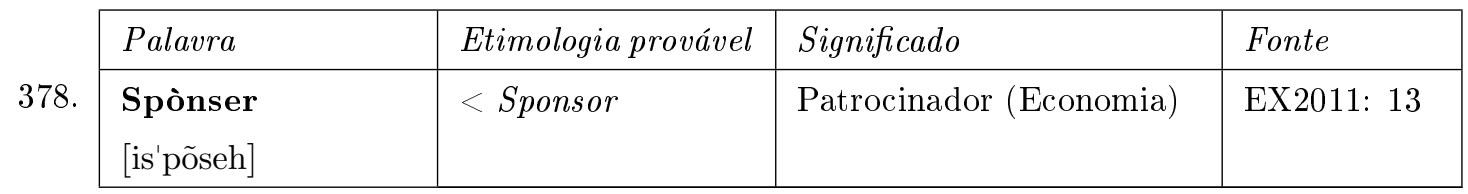

\begin{tabular}{|l|l|l|l|l|}
\hline 379. & Palavra & Etimologia provável & Significado & Fonte \\
\cline { 2 - 5 } & $\begin{array}{l}\text { Spòrtif } \\
\text { [ispor'tif }]\end{array}$ & Esportivo (Esporte) & RH2008: 244 \\
\hline
\end{tabular}

\begin{tabular}{|l|l|l|l|l|}
\hline 380. & Palavra & Etimologia provável & Significado & Fonte \\
\cline { 2 - 4 } & $\begin{array}{l}\text { Stadion } \\
{[\text { ista'djõ }]}\end{array}$ & $<$ Stadion & Estádio (Esporte) & D86: 176 \\
\hline
\end{tabular}

\begin{tabular}{|l|l|l|l|}
\hline Palavra & Etimologia provável & Significado & Fonte \\
\hline $\begin{array}{l}\text { Stir }{ }^{\mathbf{1 6 3}} \\
{[\text { is'tyh }]}\end{array}$ & $<$ Steer & $\begin{array}{l}\text { Dirigir (Tecnologia e De- } \\
\text { Senvolvimento) }\end{array}$ & $\begin{array}{l}\text { RH2008: } \\
246\end{array}$ \\
\hline
\end{tabular}

382 .

\begin{tabular}{|l|l|l|l|}
\hline Palavra & Etimologia provável & Significado & Fonte \\
\hline $\begin{array}{l}\text { Stirdón } \\
\text { [istih'do }\end{array}$ & $\longleftarrow$ Steer & Motorista (Tecnologia e & RH2008: \\
& & Desenvolvimento) & 246 \\
\hline
\end{tabular}

383.

\begin{tabular}{|l|l|l|l|}
\hline Palavra & Etimologia provável & Significado & Fonte \\
\hline $\begin{array}{l}\text { Stirmentu165 } \\
\text { [istihmẽtu] }\end{array}$ & $\longleftarrow$ Steer & $\begin{array}{l}\text { Condução (Tecnologia e } \\
\text { Desenvolvimento) }\end{array}$ & RH2008: \\
& & 246 \\
\hline
\end{tabular}

\begin{tabular}{|l|l|l|l|}
\hline Palavra & Etimologia provável & Significado & Fonte \\
\hline Stog. & $<$ Stoof & Fogão (Tecnologia e Desen- & RH2008: \\
vis'toh $]$ & & volvimento) & 247 \\
\hline
\end{tabular}

\begin{tabular}{|l|l|l|l|}
\hline Palavra & Etimologia provável & Significado & Fonte \\
\hline $\begin{array}{l}\text { Stür166 } \\
\text { [is'tyh }]\end{array}$ & $\longleftarrow$ Steer & $\begin{array}{l}\text { Dirigir (Tecnologia e De- } \\
\text { senvolvimento) }\end{array}$ & $\begin{array}{l}\text { RH2008: } \\
246\end{array}$ \\
\hline
\end{tabular}

\footnotetext{
${ }^{163}$ Varia com manehá $a_{166}$ e stür ${ }_{385}$.

164 Varia com stürdós ${ }_{386}$.

165 Varia com stürmentu $u_{387}$.

${ }^{166}$ Varia com stir ${ }_{381}$ e manehá $a_{166}$.
} 
386.

\begin{tabular}{|c|c|c|c|}
\hline Palavra & Etimologia provável & Significado & Fonte \\
\hline $\begin{array}{l}\text { Stürdóo } \\
\text { [istyh'do] }\end{array}$ & $\longleftarrow$ Steer & $\begin{array}{l}\text { Motorista (Tecnologia e } \\
\text { Desenvolvimento) }\end{array}$ & $\begin{array}{l}\text { RH2008: } \\
246\end{array}$ \\
\hline
\end{tabular}

387.

\begin{tabular}{|l|l|l|l|}
\hline Palavra & Etimologia provável & Significado & Fonte \\
\hline $\begin{array}{l}\text { Stürmentu } \\
\text { [istyh'mẽtu] }\end{array}$ & $\longleftarrow$ Steer & Condução (Tecnologia e & RH2008: \\
& & Desenvolvimento) & 246 \\
\hline
\end{tabular}

\begin{tabular}{|l|l|l|l|}
\hline Palavra & Etimologia provável & Significado & Fonte \\
\hline Taipraiter & $<$ Typewriter & $\begin{array}{l}\text { Máquina de escrever } \\
\text { (Tecnologia e Desenvolvi- } \\
\text { mento) }\end{array}$ & $\begin{array}{l}\text { RH2008: } \\
249\end{array}$ \\
\hline & & tej'prejteh] & \\
\hline
\end{tabular}

389.

\begin{tabular}{|l|l|l|l|}
\hline Palavra & Etimologia provável & Significado & Fonte \\
\hline $\begin{array}{l}\text { Telefon } \\
\text { [tele'fõ] }\end{array}$ & $<$ Telefoon & Telefone (Tecnologia e De- & RH2008: \\
& & senvolvimento) & 254 \\
\hline
\end{tabular}

390.

\begin{tabular}{|l|l|l|l|}
\hline Palavra & Etimologia provável & Significado & Fonte \\
\hline $\begin{array}{l}\text { Telegraf } \\
\text { [tele'graf] }\end{array}$ & $<$ Telegraaf & Telégrafo (Tecnologia e & RH2008: \\
& & Desenvolvimento) & 254 \\
\hline
\end{tabular}

391.

\begin{tabular}{|l|l|l|l|}
\hline Palavra & Etimologia provável & Significado & Fonte \\
\hline Telegram & $<$ Telegram & Telegrama (Tecnologia e & RH2008: \\
[tele'grãm] & & Desenvolvimento) & 254 \\
& & & \\
\hline
\end{tabular}

392.

\begin{tabular}{|l|l|l|l|}
\hline Palavra & Etimologia provável & Significado & Fonte \\
\hline Tènker $\mathbf{1 6 9}$ & $<$ Tanker & Petroleiro (Tecnologia e & RH2008: \\
['tẽk $\varnothing]$ & & Desenvolvimento) & 254 \\
& & & \\
\hline
\end{tabular}

393.

\begin{tabular}{|l|l|l|l|}
\hline Palavra & Etimologia provável & Significado & Fonte \\
\hline $\begin{array}{l}\text { Trein } \\
\text { ['trẽ̃]] }\end{array}$ & $<$ Trein & Treinar (Esporte) & RH2008: 260 \\
\hline
\end{tabular}

167 Varia com stirdó 382 .

168 Varia com stirmentu s $_{383}$.

169 Varia com Tanker 523 . 


\begin{tabular}{|l|l|l|l|}
\hline Palavra & Etimologia provável & Significado & Fonte \\
\hline $\begin{array}{l}\text { Treiningspak } \\
\text { [trẽjis'pak] }\end{array}$ & $<$ Trainingspak & $\begin{array}{l}\text { Roupa de ginástica (Es- } \\
\text { porte) }\end{array}$ & RH2008: 261 \\
\hline
\end{tabular}

\begin{tabular}{|l|l|l|l|}
\hline 395. & Etimologia provável & Significado & Fonte \\
\cline { 2 - 4 } & $\begin{array}{l}\text { Treinmentu } \\
\text { [trõ̃j'mẽtu }]\end{array}$ & Treinamento (Esporte) & RH2008: 261 \\
\hline
\end{tabular}

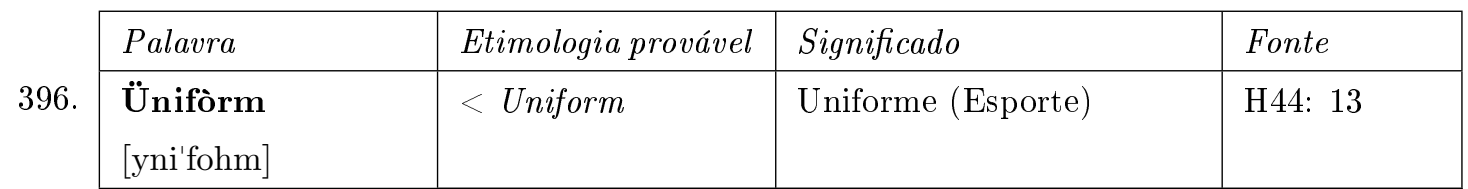

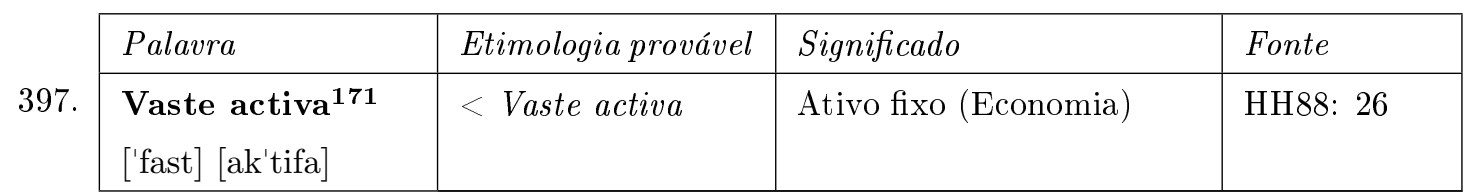

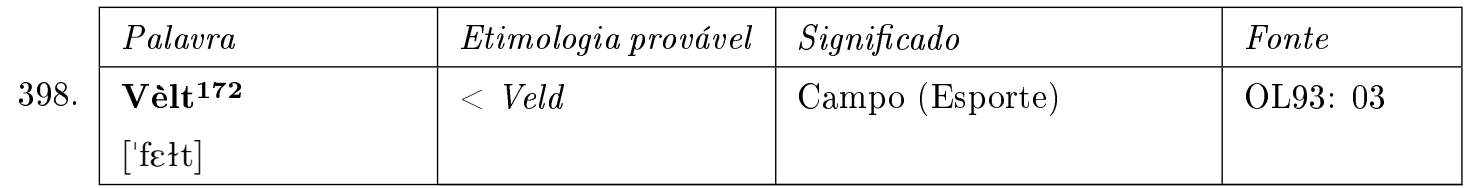

\begin{tabular}{|l|l|l|l|}
\hline Palavra & Etimologia provável & Significado & Fonte \\
\hline 399. & $\begin{array}{l}\text { Vidiorikòrder } \\
\text { [fidiori'kohdeh] }\end{array}$ & $<$ Videorecorder & Filmadora (Tecnologia e \\
& Desenvolvimento) & $\begin{array}{l}\text { RH2008: } \\
271\end{array}$ \\
\hline
\end{tabular}

\begin{tabular}{|l|l|l|l|l|}
\hline 400. & Palavra & Etimologia provável & Significado & Fonte \\
\cline { 2 - 4 } & $\begin{array}{l}\text { Vli } \\
{[\text { 'fli }]}\end{array}$ & $<$ Vlieger & Pipa (Esporte) & H44: 58 \\
\hline
\end{tabular}

\begin{tabular}{|c|c|c|c|c|}
\hline & Palavra & Etimologia provável & Significado & Fonte \\
\hline 401. & 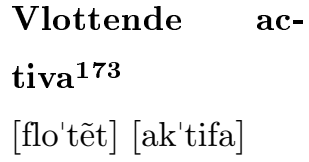 & $<$ Vlottende activa & $\begin{array}{l}\text { Capital ativo, circulante } \\
\text { (Economia) }\end{array}$ & HH88: 40 \\
\hline
\end{tabular}

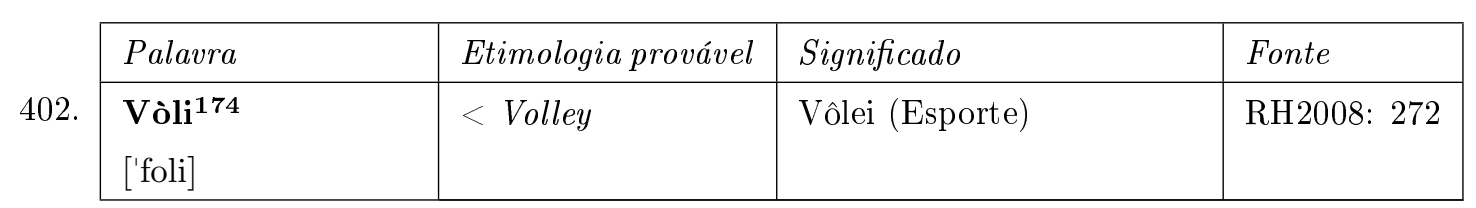

170 Varia com adiestramentu . $_{3}$.

${ }^{171}$ Varia com aktivo fiho ${ }_{14}$.

172 Varia com fèlt ${ }_{285}$.

173 Varia com kapital sirkulante 675 .

174 Varia com vòlibòl ${ }_{403}$. 


\begin{tabular}{|c|c|c|c|}
\hline Palavra & Etimologia provável & Significado & Fonte \\
\hline $\begin{array}{l}\text { 403. } \begin{array}{l}\text { Vòlibòl } \\
\text { [foli'boł }]\end{array} \\
\text { fol }\end{array}$ & $<$ Volleybal & Vôlei (Esporte) & RH2008: 272 \\
\hline
\end{tabular}

404

\begin{tabular}{|l|l|l|l|}
\hline Palavra & Etimologia provável & Significado & Fonte \\
\hline Wasmashin $\mathbf{1 7 6}$ & $<$ Wasmachine & $\begin{array}{l}\text { Máquina de lavar (Tecno- } \\
\text { logia e Desenvolvimento) }\end{array}$ & $\begin{array}{l}\text { RH2008: } \\
\text { [wasma' [i] }\end{array}$ \\
& & & \\
\hline
\end{tabular}

405 .

\begin{tabular}{|l|l|l|l|}
\hline Palavra & Etimologia provável & Significado & Fonte \\
\hline Xerox & $<$ Xerox & Copiar, cópia (Tecnologia e & RH2008: \\
[zi'xokis] & & Desenvolvimento) & 163 \\
& & & \\
\hline
\end{tabular}

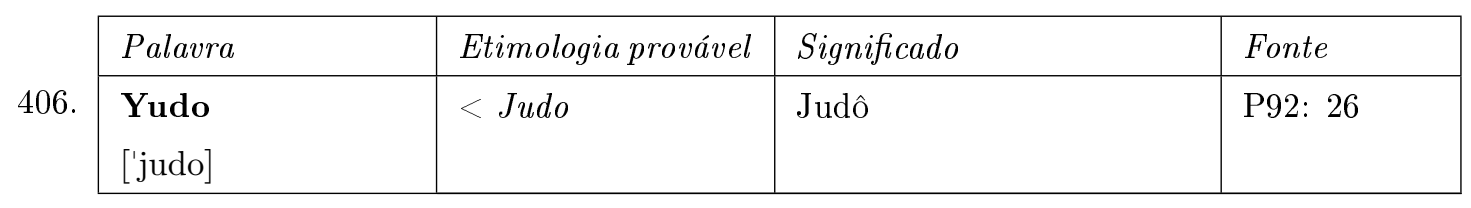

\begin{tabular}{|l|l|l|l|}
\hline Palavra & Etimologia provável & Significado & Fonte \\
\hline Zag & $<$ Zaag & Serra (Tecnologia e Desen- & RH2008: \\
['zah] & & volvimento) & 282 \\
\hline
\end{tabular}

\begin{tabular}{|l|l|l|l|}
\hline Palavra & Etimologia provável & Significado & Fonte \\
\hline $\begin{array}{l}\text { Zagmashin } \\
\text { [zahma'fi] }]\end{array}$ & $<$ Zaagmachine & $\begin{array}{l}\text { Serra (Tecnologia e Desen- } \\
\text { volvimento) }\end{array}$ & $\begin{array}{l}\text { RH2008: } \\
\end{array}$ \\
& & & 163 \\
\hline
\end{tabular}

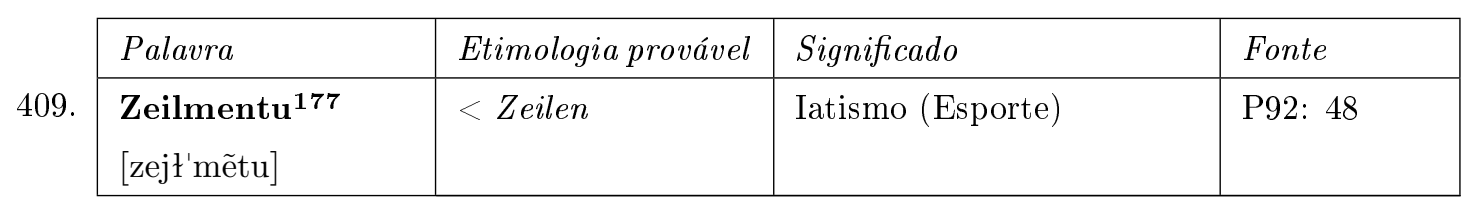

\begin{tabular}{|l|l|l|l|}
\hline Palavra & Etimologia provável & Significado & Fonte \\
\hline Z10. & $<$ Xerox & Copiar, cópia (Tecnologia e & RH2008: \\
[zi'rokis] & & Desenvolvimento) & 163 \\
\hline
\end{tabular}

175 Varia com vòli ${ }_{402}$.

176 Varia com mashin di laba pañ $a_{915}$.

177 Varia com seilmentu ${ }_{510}$. 
411.

\begin{tabular}{|l|l|l|l|}
\hline Palavra & Etimologia provável & Significado & Fonte \\
\hline $\begin{array}{l}\text { Zona di foul } \\
\text { ['zona] [di] ['fow] }\end{array}$ & $<$ Zona foul & $\begin{array}{l}\text { Parte do campo de beise- } \\
\text { bol (Esporte) }\end{array}$ & D86: 177 \\
& & & \\
\hline
\end{tabular}

412

\begin{tabular}{|l|l|l|l|}
\hline Palavra & Etimologia provável & Significado & Fonte \\
\hline $\begin{array}{l}\text { Zona di strike } \\
\text { ['zona] [di] [is'trajk] }\end{array}$ & $<$ Zona strike & $\begin{array}{l}\text { Parte do campo de beise- } \\
\text { bol (Esporte) }\end{array}$ & D86: 177 \\
& & & \\
\hline
\end{tabular}

413.

\begin{tabular}{|l|l|l|l|}
\hline Palavra & Etimologia provável & Significado & Fonte \\
\hline $\begin{array}{l}\text { Zuèmpul } \\
\text { ['zwẽpuł }]\end{array}$ & $\longleftarrow$ Zwembad / & $\begin{array}{l}\text { Piscina de natação (Es- } \\
\text { porte) }\end{array}$ & RH2008: 284 \\
& Pool & & \\
\hline
\end{tabular}

\section{INGLÊS}

414.

\begin{tabular}{|l|l|l|l|}
\hline Palavra & Etimologia provável & Significado & Fonte \\
\hline $\begin{array}{l}\text { BlackBerry } \\
\text { ['blek] ['beri] }\end{array}$ & $<$ BlackBerry & $\begin{array}{l}\text { BlackBerry (Tecnologia e } \\
\text { Desenvolvimento) }\end{array}$ & EX2011: 13 \\
\hline
\end{tabular}

415.

\begin{tabular}{|l|l|l|l|}
\hline Palavra & Etimologia provável & Significado & Fonte \\
\hline $\begin{array}{l}\text { Body building } \mathbf{1 7 8} \\
\text { ['bodi] ['biwłdĩ] }\end{array}$ & $<$ Body building & Musculação (Esporte) & EX2011: 4 \\
\hline
\end{tabular}

416.

\begin{tabular}{|l|l|l|l|}
\hline Palavra & Etimologia provável & Significado & Fonte \\
\hline $\begin{array}{l}\text { Body Fitness } \\
\text { ['bodi] ['fitnes] }\end{array}$ & $<$ Body fitness & Musculação (Esporte) & EX2011: 4 \\
\hline
\end{tabular}

417.

\begin{tabular}{|l|l|l|l|}
\hline Palavra & Etimologia provável & Significado & Fonte \\
\hline $\begin{array}{l}\text { Bodybuilder } \\
\text { ['bodi] ['biwłdeh] }\end{array}$ & $<$ Bodybuilder & Fisiocultu-rista (Esporte) & OLA2011: 9 \\
\hline
\end{tabular}

418.

\begin{tabular}{|l|l|l|l|}
\hline Palavra & Etimologia provável & Significado & Fonte \\
\hline $\begin{array}{l}\text { Break-even } \\
\text { ['brejk] ['ejfẽ] }\end{array}$ & $<$ Breakeven & $\begin{array}{l}\text { Ponto de equilíbrio (Eco- } \\
\text { nomia) }\end{array}$ & HH88: 16 \\
& & & \\
\hline
\end{tabular}

419.

\begin{tabular}{|l|l|l|l|}
\hline Palavra & Etimologia provável & Significado & Fonte \\
\hline $\begin{array}{l}\text { Budget } \\
{\left[\mathrm{b} \emptyset{ }^{\prime} \mathrm{d} 3^{\varepsilon \mathrm{t}}\right]}\end{array}$ & $<$ Budget & Orçamento (Economia) & EX2011:05 \\
\hline
\end{tabular}

178 Varia com body fitness ${ }_{416}$.

179 Varia com body building ${ }_{415}$. 
20.

\begin{tabular}{|l|l|l|l|}
\hline Palavra & Etimologia provável & Significado & Fonte \\
\hline $\begin{array}{l}\text { Centerfield } \\
\text { [sẽtch'fiłd] }\end{array}$ & $<$ Centerfielding & $\begin{array}{l}\text { Parte central do campo de } \\
\text { beisebol (Esporte) }\end{array}$ & D86: 165 \\
& & & \\
\hline
\end{tabular}

421.

\begin{tabular}{|c|c|c|c|}
\hline Palavra & Etimologia provável & Significado & Fonte \\
\hline $\begin{array}{l}\text { Centerfielder } \\
\text { [sẽtch'fiłdch] }\end{array}$ & $<$ Centerfielder & $\begin{array}{l}\text { Jogadores que jogam den- } \\
\text { tro do centerfield (parte } \\
\text { central do campo de beise- } \\
\text { bol) (Esporte) }\end{array}$ & D86: 165 \\
\hline
\end{tabular}

422.

\begin{tabular}{|l|l|l|l|}
\hline Palavra & Etimologia provável & Significado & Fonte \\
\hline $\begin{array}{l}\text { Championship } \\
\text { ['tfẽpiõofip] }\end{array}$ & $<$ Championship & Campeonato (Esporte) & EX2011: 8 \\
\hline
\end{tabular}

423.

\begin{tabular}{|l|l|l|l|}
\hline Palavra & Etimologia provável & Significado & Fonte \\
\hline $\begin{array}{l}\text { Chès } \\
\left.\text { ['t } \int_{\varepsilon s}\right]\end{array}$ & $<$ Chess & Xadrez (Esporte) & RH2008: 40 \\
\hline
\end{tabular}

424.

\begin{tabular}{|l|l|l|l|}
\hline Palavra & Etimologia provável & Significado & Fonte \\
\hline $\begin{array}{l}\text { Daif } \\
{[\text { 'dajf }]}\end{array}$ & $<$ Dive & Mergulhar (Esporte) & RH2008: 44 \\
\hline
\end{tabular}

425 .

\begin{tabular}{|l|l|l|l|}
\hline Palavra & Etimologia provável & Significado & Fonte \\
\hline $\begin{array}{l}\text { Deadball } \\
\text { [det'boł }]\end{array}$ & $<$ Dead Ball & $\begin{array}{l}\text { Tipo de lançamento em } \\
\text { beisebol (Esporte) }\end{array}$ & D86: 165 \\
\hline
\end{tabular}

426.

\begin{tabular}{|l|l|l|l|}
\hline Palavra & Etimologia provável & Significado & Fonte \\
\hline $\begin{array}{l}\text { Dil182 } \\
\text { ['dił }]\end{array}$ & $<$ Deal & Negociar (Economia) & RH2008: 54 \\
\hline
\end{tabular}

\begin{tabular}{|l|l|l|l|}
\hline Palavra & Etimologia provável & Significado & Fonte \\
\hline Dobbel play & $<$ Double play & $\begin{array}{l}\text { Quando numa jogada são } \\
\text { eliminados 2 jogadores de } \\
\text { uma equipe (Esporte) }\end{array}$ & \\
[do'bet] ['plej] & & & \\
& & & \\
\hline
\end{tabular}

180 Varia com kampionato k69 $_{66}$.

181 Varia com ahedres .

182 Varia com negoshá 750. 


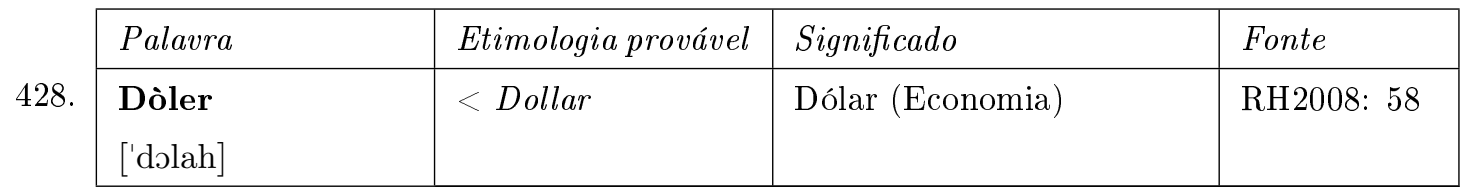

429.

\begin{tabular}{|l|l|l|l|}
\hline Palavra & Etimologia provável & Significado & Fonte \\
\hline $\begin{array}{l}\text { Doping } \\
\text { ['dəpĩ] }\end{array}$ & $<$ Doping & Doping (Esporte) & P92: 27 \\
\hline
\end{tabular}

430.

\begin{tabular}{|l|l|l|l|}
\hline Palavra & Etimologia provável & Significado & Fonte \\
\hline $\begin{array}{l}\text { Eksrei } \\
\text { ['Ekisrej }]\end{array}$ & $<X$-ray & $\begin{array}{l}\text { Raio-x (Tecnologia e De- } \\
\text { senvolvimento) }\end{array}$ & RH2008: 65 \\
\hline
\end{tabular}

431.

\begin{tabular}{|l|l|l|l|}
\hline Palavra & Etimologia provável & Significado & Fonte \\
\hline Eksrei & $<X$-ray & $\begin{array}{l}\text { Radiografar (Tecnologia e } \\
\text { Desenvolvimento) }\end{array}$ & RH2008: 65 \\
{$[$ 'Ekisrej] } & & \\
\hline
\end{tabular}

432.

\begin{tabular}{|l|l|l|l|}
\hline Palavra & Etimologia provável & Significado & Fonte \\
\hline $\begin{array}{l}\text { Ekstasis } \\
\text { [ekista'sis }]\end{array}$ & $<$ Ecstasy & $\begin{array}{l}\text { Ecstasy (Tecnologia e De- } \\
\text { senvolvimento) }\end{array}$ & RH2008: 65 \\
\hline
\end{tabular}

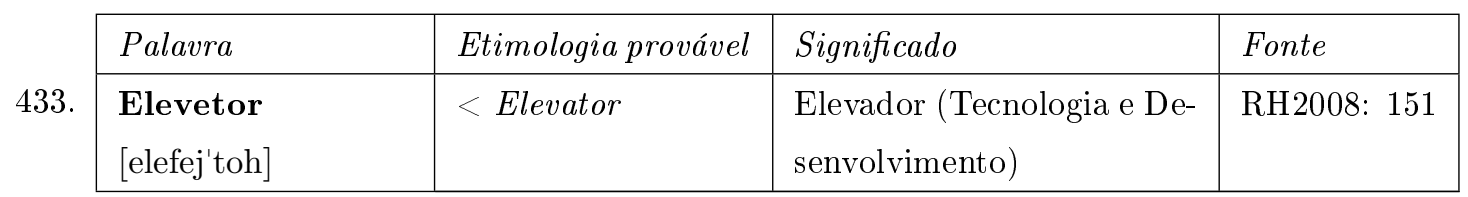

\begin{tabular}{|l|l|l|l|}
\hline Palavra & Etimologia provável & Significado & Fonte \\
\hline Eliometer & $<$ Heliometer & Heliômetro, instrumento & RH2008: 67 \\
[elio'metre $]$ & óptico para determinar o & \\
& & diâmetro aparente do Sol e & \\
& medir a distância angular & \\
& entre dois corpos celestes & \\
& em estreita proximidade & \\
& entre si (Tecnologia e & \\
& Desenvolvimento) & \\
\hline
\end{tabular}

\begin{tabular}{|l|l|l|l|}
\hline Palavra & Etimologia provável & Significado & Fonte \\
\hline Email & $<$ Email & $\begin{array}{l}\text { E-mail ou correio eletrô- } \\
\text { nico (Tecnologia e Desen- } \\
\text { volvimento) }\end{array}$ & EX2011: 11 \\
\hline i'mej] & & & \\
\hline
\end{tabular}

183 Varia com ròntgenstral 356 . 
436

\begin{tabular}{|l|l|l|l|}
\hline Palavra & Etimologia provável & Significado & Fonte \\
\hline $\begin{array}{l}\text { Erko }{ }^{\mathbf{1 8 4}} \\
{[\text { 'Ehko }]}\end{array}$ & $\begin{array}{l}\text { Air conditioner } \\
\text { Aparelho de ar condicio- } \\
\text { nado (Tecnologia e Desen- } \\
\text { volvimento) }\end{array}$ & RH2008: 71 \\
\hline
\end{tabular}

437

\begin{tabular}{|l|l|l|l|}
\hline Palavra & Etimologia provável & Significado & Fonte \\
\hline $\begin{array}{l}\text { Erkondeshen } \mathbf{1 8 5} \\
\text { [Ehko'dẽfẽ }]\end{array}$ & $<$ Air conditioner & $\begin{array}{l}\text { Aparelho de ar condicio- } \\
\text { nado (Tecnologia e Desen- } \\
\text { volvimento) }\end{array}$ & RH2008: 71 \\
& & \\
\hline
\end{tabular}

438.

\begin{tabular}{|l|l|l|l|}
\hline Palavra & Etimologia provável & Significado & Fonte \\
\hline Extra base & $<$ Extra base & Tipo de conexão onde o jo- & D86: 166 \\
['Ekistra] ['base] & & $\begin{array}{l}\text { gador conquista mais uma } \\
\text { base (beisebol) (Esporte) }\end{array}$ & \\
& & & \\
\hline
\end{tabular}

439.

\begin{tabular}{|c|c|c|c|}
\hline Palavra & Etimologia provável & Significado & Fonte \\
\hline $\begin{array}{l}\text { Extra inning } \\
\text { ['Ekistra] [ini] }\end{array}$ & $<$ Extra inning & $\begin{array}{l}\text { Continuação de um jogo } \\
\text { após completar-se um in- } \\
\text { ning (período em beisebol) } \\
\text { (Esporte) }\end{array}$ & D86: 166 \\
\hline
\end{tabular}

440.

\begin{tabular}{|l|l|l|l|}
\hline Palavra & Etimologia provável & Significado & Fonte \\
\hline Facebook & $<$ Facebook & Facebook, rede social vir- & EX2011: 12 \\
[fejse'buk $]$ & $\begin{array}{l}\text { tual (Tecnologia e Desen- } \\
\text { volvimento) }\end{array}$ & \\
& & \\
\hline
\end{tabular}

441.

\begin{tabular}{|l|l|l|l|}
\hline Palavra & Etimologia provável & Significado & Fonte \\
\hline $\begin{array}{l}\text { Faks } \\
\text { ['fakis] }\end{array}$ & $<$ Fax & $\begin{array}{l}\text { Fax (Tecnologia e Desen- } \\
\text { volvimento) }\end{array}$ & EX2011: 12 \\
\hline
\end{tabular}

442.

\begin{tabular}{|l|l|l|l|}
\hline Palavra & Etimologia provável & Significado & Fonte \\
\hline $\begin{array}{l}\text { Felm } \\
\text { ['fełm] }\end{array}$ & $<$ Film & $\begin{array}{l}\text { Filme (Tecnologia e Desen- } \\
\text { volvimento) }\end{array}$ & RH2008: 236 \\
\hline
\end{tabular}

443.

\begin{tabular}{|l|l|l|l|}
\hline Palavra & Etimologia provável & Significado & Fonte \\
\hline $\begin{array}{l}\text { Fèri } \\
{[\text { 'feri }]}\end{array}$ & $<$ Ferry & $\begin{array}{l}\text { Ferryboat (Tecnologia e } \\
\text { Desenvolvimento) }\end{array}$ & RH2008: 77 \\
\hline
\end{tabular}

184 Varia com erkondeshen ${ }_{437}$.

185 Varia com erko ${ }_{436}$. 


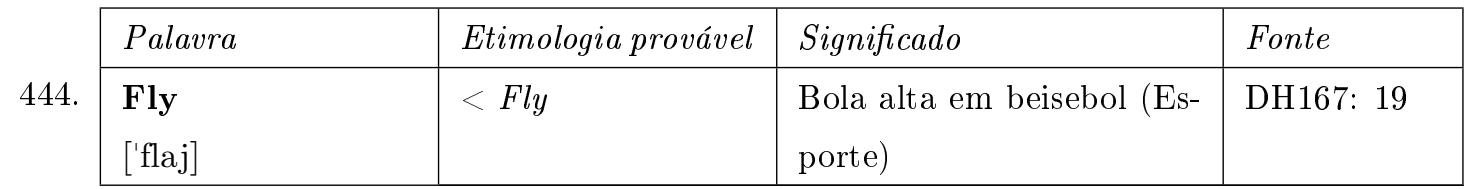

\begin{tabular}{|l|l|l|l|}
\hline Palavra & Etimologia provável & Significado & Fonte \\
\hline Forfeith & $<$ Forfeit & Jogo finalizado pelo juíz a & D86: 167 \\
{$[$ f̧h'fejf $]$} & & $\begin{array}{l}\text { favor de uma equipe por } \\
\text { razão de o outro time não }\end{array}$ & \\
& & ter 9 jogadores (beisebol) & \\
& & (Esporte) & \\
\hline
\end{tabular}

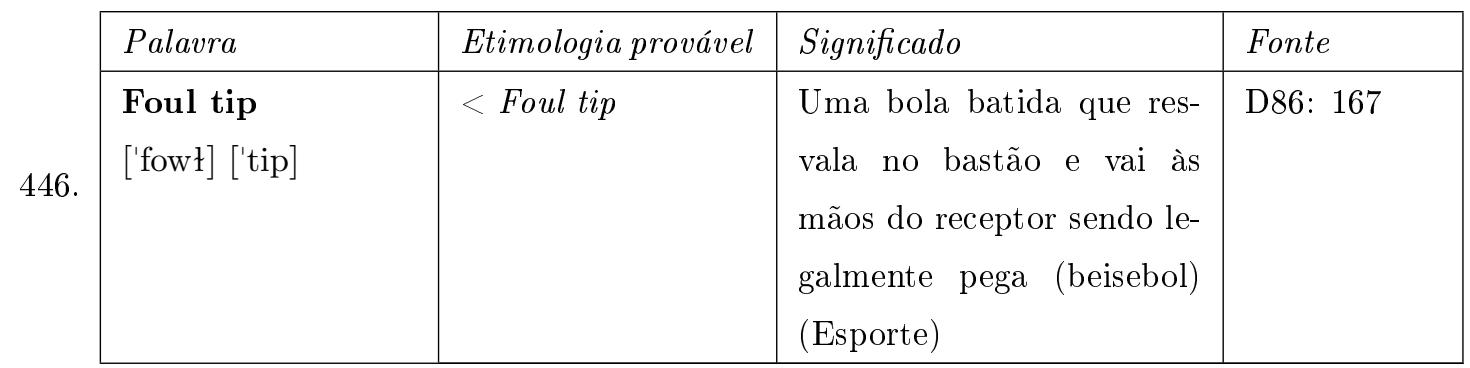

\begin{tabular}{|c|c|c|c|}
\hline Palavra & Etimologia provável & Significado & Fonte \\
\hline $\begin{array}{l}\text { Foulball }{ }^{186} \\
\text { ['fowłboł] }\end{array}$ & $<$ Foul ball & $\begin{array}{l}\text { Batimento irregular, para } \\
\text { fora das linhas laterais do } \\
\text { campo. Determina que o } \\
\text { jogo pare (bola morta) e } \\
\text { some uma tentativa para o } \\
\text { batedor (Esporte) }\end{array}$ & D86: 167 \\
\hline
\end{tabular}

\begin{tabular}{|l|l|l|l|}
\hline Palavra & Etimologia provável & Significado & Fonte \\
\hline Foulbòl ${ }^{\mathbf{1 8 7}}$ & $<$ Foul ball & Batimento irregular, para & RH2008: 83 \\
['fowtboł $]$ & & $\begin{array}{l}\text { fora das linhas laterais do } \\
\text { campo. Determina que o }\end{array}$ & \\
& & $\begin{array}{l}\text { jogo pare (bola morta) e } \\
\text { some uma tentativa para o } \\
\end{array}$ & \\
& & batedor (Esporte) & \\
\hline
\end{tabular}

\begin{tabular}{|l|l|l|l|}
\hline Palavra & Etimologia provável & Significado & Fonte \\
\hline $\begin{array}{l}\text { Frishidèr } \mathbf{1 8 8} \\
{[\text { frifi'deh }]}\end{array}$ & $<$ Freezer & $\begin{array}{l}\text { Congelador, freezer (Tec- } \\
\text { nologia e Desenvolvi- } \\
\text { mento) }\end{array}$ & RH2008: 84 \\
\hline
\end{tabular}

\footnotetext{
186 Varia com foulbòl ${ }_{448}$.

187 Varia com Foulball 447 .

188 Varia com frizjidèr $_{450}$.
} 
450.

\begin{tabular}{|l|l|l|l|}
\hline Palavra & Etimologia provável & Significado & Fonte \\
\hline Frizjidèr $\mathbf{1 8 9}$ & $<$ Freezer & $\begin{array}{l}\text { Congelador, freezer (Tec- } \\
\text { nologia e Desenvolvi- } \\
\text { [frizi'deh] }\end{array}$ & mento)
\end{tabular}

451.

\begin{tabular}{|l|l|l|l|}
\hline Palavra & Etimologia provável & Significado & Fonte \\
\hline $\begin{array}{l}\text { Gasòil } \\
\text { [gasoił }]\end{array}$ & $<$ Gasoil & $\begin{array}{l}\text { Óleo diesel (Tecnologia e } \\
\text { Desenvolvimento) }\end{array}$ & RH2008: 88 \\
\hline
\end{tabular}

452.

\begin{tabular}{|l|l|l|l|}
\hline Palavra & Etimologia provável & Significado & Fonte \\
\hline $\begin{array}{l}\text { Golf } \\
{[\text { 'gətf }]}\end{array}$ & $<$ Golf & Golf (Esporte) & RH2008: 90 \\
\hline
\end{tabular}

453.

\begin{tabular}{|l|l|l|l|}
\hline Palavra & Etimologia provável & Significado & Fonte \\
\hline $\begin{array}{l}\text { Golkiper190 } \\
\text { [goł'kiper] }\end{array}$ & $<$ Goalkeeper & Goleiro (Esporte) & RH2008: 90 \\
\hline
\end{tabular}

454 .

\begin{tabular}{|l|l|l|l|}
\hline Palavra & Etimologia provável & Significado & Fonte \\
\hline $\begin{array}{l}\text { Hard disk } \\
\text { ['haht] ['disk] }\end{array}$ & $<$ Hard disk & $\begin{array}{l}\text { Disco rígido (Tecnologia e } \\
\text { Desenvolvimento) }\end{array}$ & RH2008: 95 \\
\hline
\end{tabular}

455 .

\begin{tabular}{|c|c|c|c|}
\hline Palavra & Etimologia provável & Significado & Fonte \\
\hline $\begin{array}{l}\text { Heroin } \\
\text { [hยгว'î] }\end{array}$ & $<$ Heroin & $\begin{array}{l}\text { Heroína (Tecnologia e De- } \\
\text { senvolvimento) }\end{array}$ & RH2008: 97 \\
\hline
\end{tabular}

456.

\begin{tabular}{|l|l|l|l|}
\hline Palavra & Etimologia provável & Significado & Fonte \\
\hline $\begin{array}{l}\text { Hètfon } \\
\text { ['hetfõ }]\end{array}$ & $<$ Headphone & $\begin{array}{l}\text { Fone de ouvido (Tecnolo- } \\
\text { gia e Desenvolvimento) }\end{array}$ & RH2008: 98 \\
\hline
\end{tabular}

457.

\begin{tabular}{|l|l|l|l|}
\hline Palavra & Etimologia provável & Significado & Fonte \\
\hline $\begin{array}{l}\text { Hit and run } \\
\text { ['hit] [ənt] ['rã] }\end{array}$ & $<$ Hit and run & $\begin{array}{l}\text { Tipo de jogada entre bate- } \\
\text { dor e corredor (Esporte) }\end{array}$ & D86: 168 \\
\hline
\end{tabular}

458.

\begin{tabular}{|l|l|l|l|}
\hline Palavra & Etimologia provável & Significado & Fonte \\
\hline $\begin{array}{l}\text { Hòki'191 } \\
{[\text { 'hoki }]}\end{array}$ & $<$ Hockey & Hóquei (Esporte) & RH2008: 99 \\
\hline
\end{tabular}

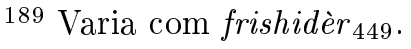

${ }^{190}$ Varia com kiper $_{471}$ e portero 198 .

191 Varia com roque 508 . 


\begin{tabular}{|l|l|l|l|}
\hline Palavra & Etimologia provável & Significado & Fonte \\
\hline Home & $<$ Home & Triângulo branco (parte do & D86: 168 \\
campo de beisebol) (Es- & \\
& & porte) & \\
\hline
\end{tabular}

460.

\begin{tabular}{|l|l|l|l|}
\hline Palavra & Etimologia provável & Significado & Fonte \\
\hline Homeklup & $<$ Home club & Equipe que começa pri- & D86: 168 \\
[hõwm'kløp] & & meiro (beisebol) (Esporte) & \\
& & & \\
\hline
\end{tabular}

461 .

\begin{tabular}{|l|l|l|l|}
\hline Palavra & Etimologia provável & Significado & Fonte \\
\hline $\begin{array}{l}\text { Inen192 } \\
\text { ['inẽn] }\end{array}$ & $<$ Inning & $\begin{array}{l}\text { Entrada (beisebol) (Es- } \\
\text { porte) }\end{array}$ & RH2008: 107 \\
& & & \\
\hline
\end{tabular}

\begin{tabular}{|c|c|c|c|}
\hline Palavra & Etimologia provável & Significado & Fonte \\
\hline $\begin{array}{l}\text { Infield } \\
\text { [î'fit] }\end{array}$ & $<$ Infield & $\begin{array}{l}\text { Campo Interior, zona do } \\
\text { campo abrangida pelas ba- } \\
\text { ses (beisebol) (Esporte) }\end{array}$ & D86: 169 \\
\hline
\end{tabular}

\begin{tabular}{|l|l|l|l|}
\hline Palavra & Etimologia provável & Significado & Fonte \\
\hline Infield fly & < Infield fly & $\begin{array}{l}\text { Balão interior - Alerta do } \\
\text { árbitit] ['flaj] }\end{array}$ & D86: 169 \\
& & $\begin{array}{l}\text { tida em balão cai no campo } \\
\text { interior. Isso acontece } \\
\text { quando há um corredor na } \\
163 .\end{array}$ & $\begin{array}{l}\text { 1a base quando a bola é ba- } \\
\text { tida e há menos de duas } \\
\text { eliminações, sendo o ba- } \\
\text { tedor automaticamente eli- } \\
\text { minado. (Beisebol) (Es- } \\
\text { porte) }\end{array}$ \\
& & \\
\hline
\end{tabular}

464.

\begin{tabular}{|l|l|l|l|}
\hline Palavra & Etimologia provável & Significado & Fonte \\
\hline $\begin{array}{l}\text { Infield hit } \\
\text { [í'fit] ['hit] }\end{array}$ & $<$ Infield hit & $\begin{array}{l}\text { Batida dentro do quadro } \\
\text { (beisebol) (Esporte) }\end{array}$ & D86: 169 \\
\hline
\end{tabular}

192 Varia com inning i66 . 


\begin{tabular}{|l|l|l|l|}
\hline Palavra & Etimologia provável & Significado & Fonte \\
\hline Infielder & $<$ Infielder & $\begin{array}{l}\text { Defesa interior, defesa do } \\
\text { campo interior (Esporte) }\end{array}$ & D86: 169 \\
\hline İfideh $]$ & & & \\
\hline
\end{tabular}

\begin{tabular}{|l|l|l|l|}
\hline Palavra & Etimologia provável & Significado & Fonte \\
\cline { 2 - 5 } & Inning & $\mathbf{1 9 3}$ \\
{$[$ i'nĩ $]$} & $<$ Inning & $\begin{array}{l}\text { Entrada (beisebol) (Es- } \\
\text { porte) }\end{array}$ & D86: 169 \\
& & & \\
\hline
\end{tabular}

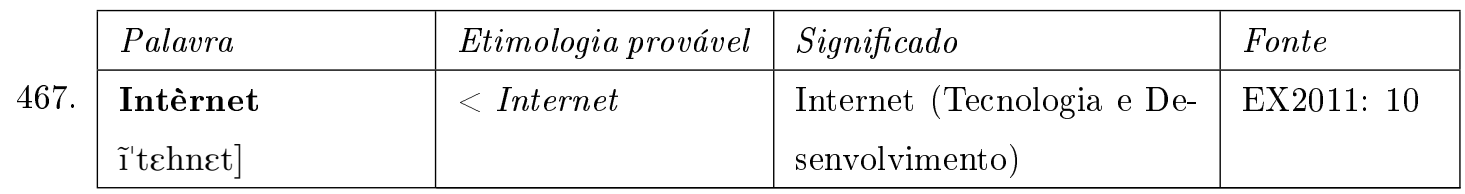

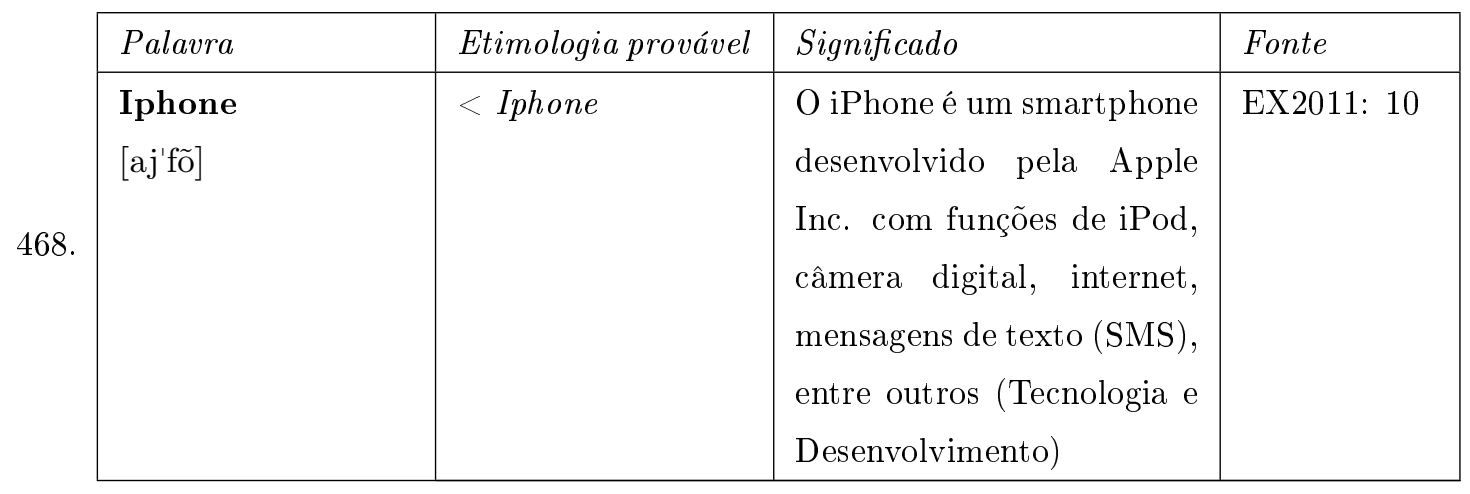

\begin{tabular}{|l|l|l|l|}
\hline Palavra & Etimologia provável & Significado & Fonte \\
\hline Jacket & $<$ Jacket & $\begin{array}{l}\text { Tipo de roupa (beisebol) } \\
\text { (Esporte) }\end{array}$ & D86: 170 \\
{$[$ 'dzekct] } & & & \\
\hline
\end{tabular}

\begin{tabular}{|c|c|c|c|c|}
\hline & Palavra & Etimologia provável & Significado & Fonte \\
\hline 470. & $\begin{array}{l}\text { Kècher } \\
{\left[\text { 'ket } \int \varepsilon r\right]}\end{array}$ & $<$ Catcher & $\begin{array}{l}\text { Receptor (beisebol) (Es- } \\
\text { porte) }\end{array}$ & EX2011: 07 \\
\hline
\end{tabular}

\begin{tabular}{|c|c|c|c|c|}
\hline & Palavra & Etimologia provável & Significado & Fonte \\
\hline 471. & $\begin{array}{l}\text { Kiper }^{194} \\
\text { ['kipeh] }\end{array}$ & $<$ Goalkeeper & Goleiro (Esporte) & OL93: 07 \\
\hline
\end{tabular}

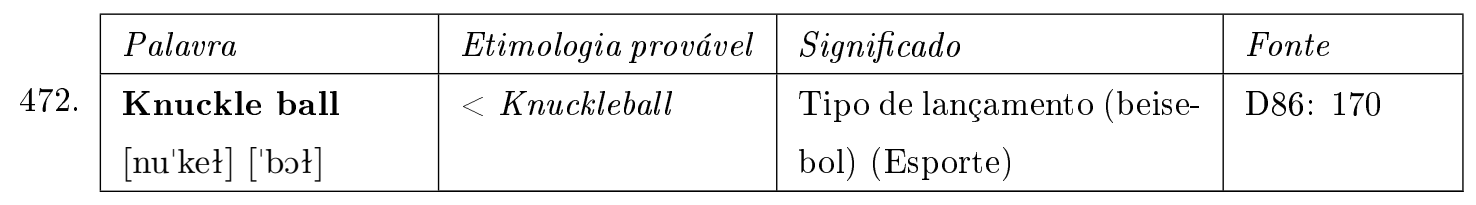

193 Varia com Inen $_{461}$.

194 Varia com golkiper 453 e portero $_{61}$. 


\begin{tabular}{|l|l|l|l|}
\hline Palavra & Etimologia provável & Significado & Fonte \\
\hline Kodak & $<$ Kodak & Kodak ou Eastman Kodak & RH2008: 130 \\
& & Company é uma empresa & \\
& & multinacional dedicada à & \\
& & comercialização de equipa- & \\
& & mentos fotográficos; rela- & \\
& & tivo à câmera (Tecnologia & \\
& e Desenvolvimento) & \\
\hline
\end{tabular}

474.

\begin{tabular}{|l|l|l|l|}
\hline Palavra & Etimologia provável & Significado & Fonte \\
\hline $\begin{array}{l}\text { Kompiuter } \\
\text { [kõ'pjuteh }]\end{array}$ & $<$ Computer & $\begin{array}{l}\text { Computador (Tecnologia e } \\
\text { Desenvolvimento) }\end{array}$ & RH2008: 134 \\
& & & \\
\hline
\end{tabular}

475.

\begin{tabular}{|l|l|l|l|}
\hline Palavra & Etimologia provável & Significado & Fonte \\
\hline $\begin{array}{l}\text { Kreditor } \\
\text { [kredi'toh }]\end{array}$ & $<$ Creditor & Creditor (Economia) & RH2008: 142 \\
\hline
\end{tabular}

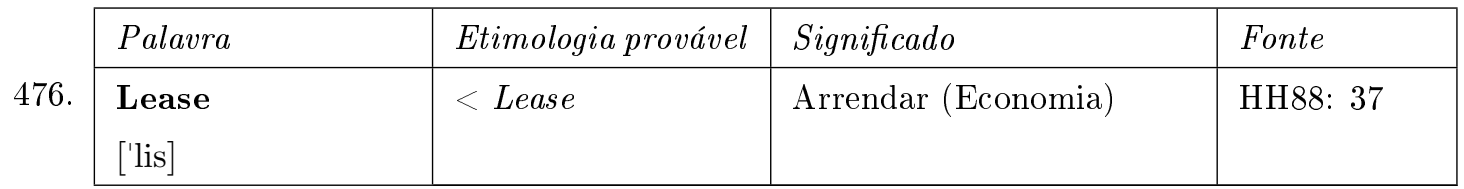

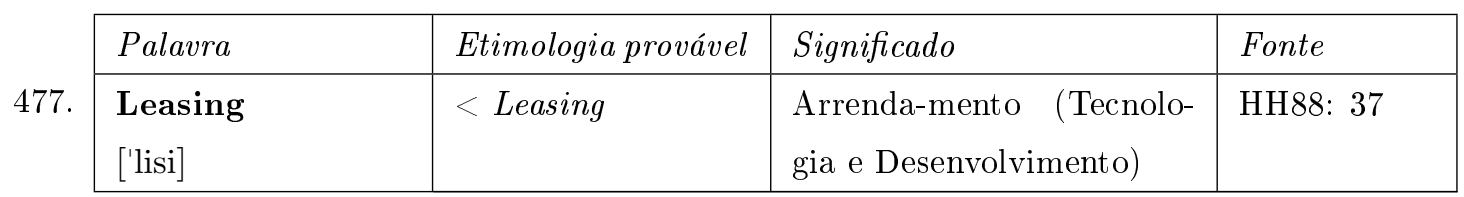

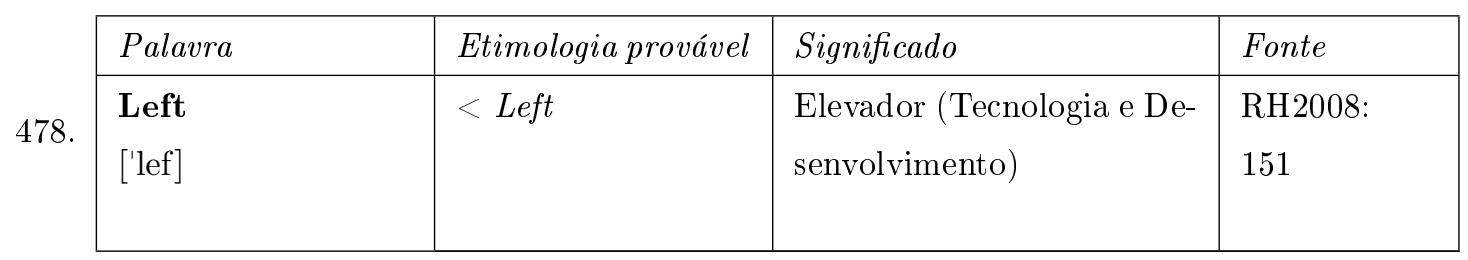

\begin{tabular}{|c|c|c|c|c|}
\hline & Palavra & Etimologia provável & Significado & Fonte \\
\hline 479. & $\begin{array}{l}\text { Leftfield } \\
{[\text { lefti'fiwłt }]}\end{array}$ & $<$ Leftfield & $\begin{array}{l}\text { Parte do campo de beise- } \\
\text { bol (Esporte) }\end{array}$ & D86: 171 \\
\hline \multirow[b]{2}{*}{480.} & Palavra & Etimologia provável & Significado & Fonte \\
\hline & $\begin{array}{l}\text { Leg } \\
\text { ['lek] }\end{array}$ & $<\operatorname{Leg}$ & Etapa (Economia) & HH88: 37 \\
\hline
\end{tabular}

195 Varia com skref 371. 
481.

\begin{tabular}{|l|l|l|l|}
\hline Palavra & Etimologia provável & Significado & Fonte \\
\hline $\begin{array}{l}\text { Lineup } \\
\text { ['lejnap] }\end{array}$ & $<$ Line-up & $\begin{array}{l}\text { Ordem de batimento (bei- } \\
\text { sebol) (Esporte) }\end{array}$ & D86: 172 \\
& & & \\
\hline
\end{tabular}

482.

\begin{tabular}{|l|l|l|l|}
\hline Palavra & Etimologia provável & Significado & Fonte \\
\hline $\begin{array}{l}\text { Little league } \\
\text { ['lirow] ['lige] }\end{array}$ & $<$ Little league & $\begin{array}{l}\text { Liga de beisebol infantil } \\
\text { (Esporte) }\end{array}$ & D86: 172 \\
& & & \\
\hline
\end{tabular}

483.

\begin{tabular}{|l|l|l|l|}
\hline Palavra & Etimologia provável & Significado & Fonte \\
\hline $\begin{array}{l}\text { Malber } \\
{[\text { mał'beh }]}\end{array}$ & $<$ Marble & Bolinha de gude (Esporte) & H44: 58 \\
\hline
\end{tabular}

484

\begin{tabular}{|l|l|l|l|}
\hline Palavra & Etimologia provável & Significado & Fonte \\
\hline Mikrokompiuter & $<$ Microcomputer & Micro-computador (Tecno- & RH2008: \\
['mikro] [kõ'pjuteh] & & logia e Desenvolvimento) & 165 \\
& & & \\
\hline
\end{tabular}

485.

\begin{tabular}{|l|l|l|l|}
\hline Palavra & Etimologia provável & Significado & Fonte \\
\hline $\begin{array}{l}\text { Motosalkel } \\
\text { [moto'sajkeł }]\end{array}$ & $<$ Motorcycle & Motocicleta (Tecnologia e & RH2008: \\
& & Desenvolvimento) & 171 \\
\hline
\end{tabular}

\begin{tabular}{|l|l|l|l|}
\hline Palavra & Etimologia provável & Significado & Fonte \\
\hline $\begin{array}{l}\text { No hit } \\
\text { [no'hit] }\end{array}$ & $\begin{array}{l}\text { Impossibi-lidade do joga- } \\
\text { dor bater dentro de nove } \\
\text { innings (períodos em beise- } \\
\text { bol) (Esporte) }\end{array}$ & D86: 172 \\
\hline
\end{tabular}

\begin{tabular}{|l|l|l|l|}
\hline Palavra & Etimologia provável & Significado & Fonte \\
\hline No hit no run & $<$ No hit no run & Um lançador é impedido & D86: 172 \\
[no'hit] [no'rã] & & $\begin{array}{l}\text { de bater (beisebol) (Es- } \\
\text { porte) }\end{array}$ & \\
\hline
\end{tabular}

488.

\begin{tabular}{|l|l|l|l|}
\hline Palavra & Etimologia provável & Significado & Fonte \\
\hline $\begin{array}{l}\text { Offshore } \\
\text { [ofi'foh] }\end{array}$ & $<$ Offshore & $\begin{array}{l}\text { Extrater-ritorial (ligado a } \\
\text { finanças) (Economia) }\end{array}$ & EX2011: 05 \\
& & & \\
\hline
\end{tabular}




\begin{tabular}{|l|l|l|l|}
\hline Palavra & Etimologia provável & Significado & Fonte \\
\hline Out & $<$ Out & Eliminação, quando um & D86: 173 \\
& atacante é eliminado pela & \\
equipe que defende. Três & \\
& eliminações implica que a \\
& equipe que atacava passa a \\
defender e vice versa (bei- & \\
& sebol) (Esporte) & \\
\hline
\end{tabular}

\begin{tabular}{|l|l|l|l|}
\hline Palavra & Etimologia provável & Significado & Fonte \\
\hline $\begin{array}{l}\text { Outfield } \\
\text { [owt'fiwłt }]\end{array}$ & $<$ Outfield & $\begin{array}{l}\text { Campo Exterior, zona do } \\
\text { campo onde não existem } \\
\text { bases (a zona mais afas- } \\
\text { tada da Casa Base) (Es- } \\
\text { porte) }\end{array}$ & \\
& & & \\
\hline
\end{tabular}

\begin{tabular}{|l|l|l|l|}
\hline Palavra & Etimologia provável & Significado & Fonte \\
\hline $\begin{array}{l}\text { Outfielder } \\
{[\text { owt'fiwłdeh }]}\end{array}$ & $<$ Outfielder & $\begin{array}{l}\text { Defesa Exterior, defesa do } \\
\text { campo exterior (beisebol) } \\
\text { (Esporte) }\end{array}$ & EX2011: 07 \\
& & & \\
\hline
\end{tabular}

\begin{tabular}{|c|c|c|c|}
\hline Palavra & Etimologia provável & Significado & Fonte \\
\hline $\begin{array}{l}\text { Picha } \\
\text { ['pitfa] }\end{array}$ & $<$ Pitch & Arremessar (Esporte) & RH2008: 197 \\
\hline
\end{tabular}

\begin{tabular}{|l|l|l|l|l|}
\hline 493. & Palavra & Etimologia provável & Significado & Fonte \\
\cline { 2 - 5 } & $\begin{array}{l}\text { Picher }{ }^{\mathbf{9 6}} \\
{[\text { 'pit]eh }]}\end{array}$ & $\begin{array}{l}\text { Lançador (beisebol) (Es- } \\
\text { porte) }\end{array}$ & RH2008: 197 \\
\hline
\end{tabular}

\begin{tabular}{|l|l|l|l|l|}
\hline 494. & Palavra & Etimologia provável & Significado & Fonte \\
\cline { 2 - 4 } & $\begin{array}{l}\text { Pichera } \\
\text { [pi't]era] }]\end{array}$ & $\begin{array}{l}\text { Protetor para barriga (Bei- } \\
\text { sebol) (Esporte) }\end{array}$ & D86: 173 \\
\hline
\end{tabular}

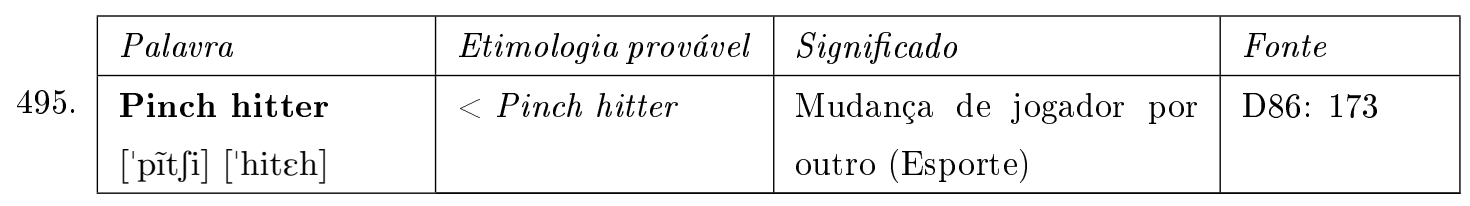

${ }^{196}$ Varia com pitcher ${ }_{496}$. 


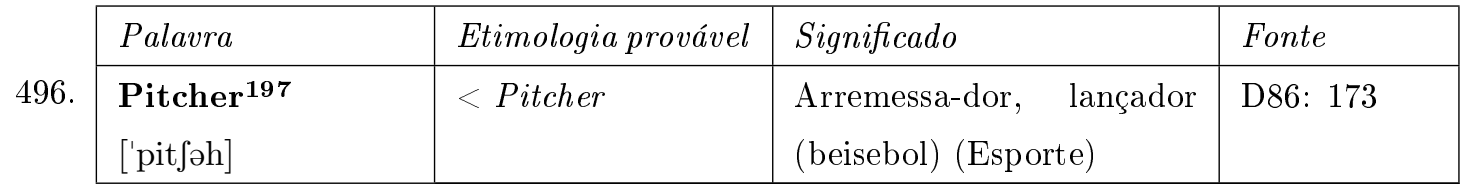

497.

\begin{tabular}{|l|l|l|l|}
\hline Palavra & Etimologia provável & Significado & Fonte \\
\hline $\begin{array}{l}\text { Play ball } \\
\text { ['plej] ['boł] }\end{array}$ & $<$ Play ball & $\begin{array}{l}\text { Comando do técnico (bei- } \\
\text { sebol) (Esporte) }\end{array}$ & D86: 173 \\
\hline
\end{tabular}

\begin{tabular}{|c|c|c|c|}
\hline Palavra & Etimologia provável & Significado & Fonte \\
\hline $\begin{array}{l}\text { Play off }^{198} \\
\text { ['plejof] }\end{array}$ & $<$ Play off & $\begin{array}{l}\text { Conjuntos de jogos, geral- } \\
\text { mente disputados após a } \\
\text { época normal de competi- } \\
\text { ção, para desempatar, de- } \\
\text { terminar um vencedor ou } \\
\text { para apurar para outra fase } \\
\text { ou para outra competição } \\
\text { (Esporte) }\end{array}$ & D86: 173 \\
\hline
\end{tabular}

\begin{tabular}{|l|l|l|l|}
\hline Palavra & Etimologia provável & Significado & Fonte \\
\hline Playoff ${ }^{199}$ & $<$ Play off & Conjuntos de jogos, geral- & OL93: 03 \\
['plejof] & & mente disputados após a & \\
& & época normal de competi- & \\
& & ção, para desempatar, de- & \\
& & terminar um vencedor ou & \\
& para apurar para outra fase & \\
& & ou para outra competição & \\
& & (Esporte) & \\
& & & \\
& & &
\end{tabular}

\begin{tabular}{|l|l|l|l|}
\hline Palavra & Etimologia provável & Significado & Fonte \\
\hline $\begin{array}{l}\text { Pòmp di gasolin } \\
\text { ['põp] [di] [gaso'lĩ] }\end{array}$ & $<$ Gasoline pump & $\begin{array}{l}\text { Bomba de gasolina (Tecno- } \\
\text { logia e Desenvolvimento) }\end{array}$ & $\begin{array}{l}\text { RH2008: } \\
88\end{array}$ \\
\hline
\end{tabular}

197 Varia com Picher $_{493}$.

198 Varia com Playoff 499 .

199 Varia com Play off 498. 


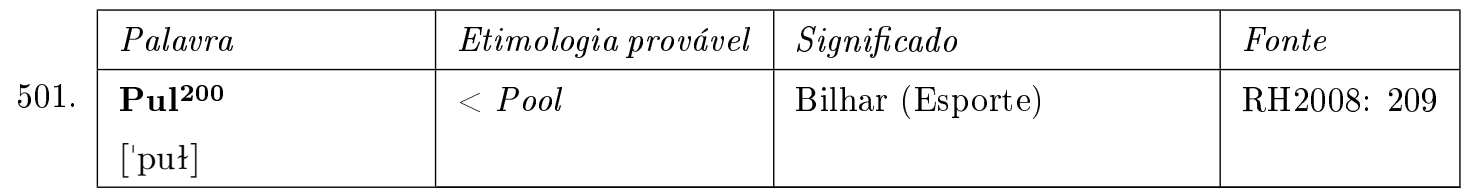

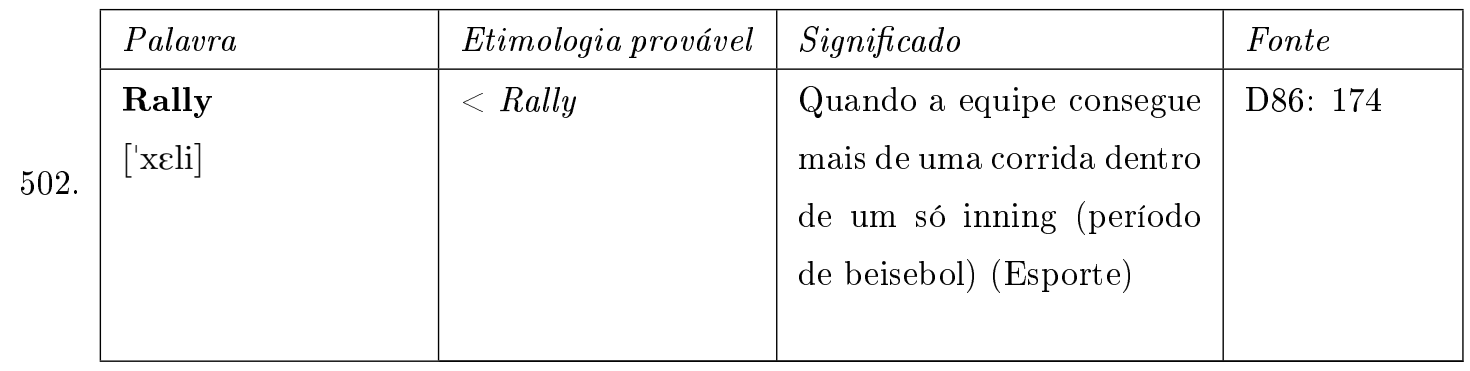

\begin{tabular}{|l|l|l|l|}
\hline Palavra & Etimologia provável & Significado & Fonte \\
\cline { 2 - 5 } & Ranking & Ranking, posição (Es- & OL93: 25 \\
{$[$ rẽ'kĩ $]$} & $<$ Ranking & porte) & \\
\hline
\end{tabular}

\begin{tabular}{|l|l|l|l|}
\hline Palavra & Etimologia provável & Significado & Fonte \\
\hline Reebok & $<$ Reebok & $\begin{array}{l}\text { Tênis (em alusão à marca } \\
\text { Reebok) (Esporte) }\end{array}$ & OL93: 03 \\
{$[$ 'ribuk] } & & & \\
\hline
\end{tabular}

\begin{tabular}{|l|l|l|l|}
\hline Palavra & Etimologia provável & Significado & Fonte \\
\hline R05. & $<$ Rightfield & Jardineiro-direito (parte & OL93: 03 \\
[rajt'fiwłt $]$ & & $\begin{array}{l}\text { do campo de beisebol) } \\
\text { (Esporte) }\end{array}$ & \\
& & & \\
\hline
\end{tabular}

\begin{tabular}{|l|l|l|l|}
\hline Palavra & Etimologia provável & Significado & Fonte \\
\hline R06. & $<$ Rightfielder & $\begin{array}{l}\text { Jogador que fica dentro } \\
\text { do jardineiro-direito (bei- } \\
\text { [rajt'fiwłdeh] }\end{array}$ & OL93: 03 \\
& & & \\
& & & \\
\hline
\end{tabular}

\begin{tabular}{|l|l|l|l|}
\hline Palavra & Etimologia provável & Significado & Fonte \\
\hline R07. & $<$ Ringtone & $\begin{array}{l}\text { Música para toque de celu- } \\
\text { lar (Tecnologia e Desenvol- } \\
\text { [rĩk'tõne] }\end{array}$ & EX2011: 05 \\
& & & \\
& & & \\
\hline
\end{tabular}

200 Varia com billar $_{42}$. 


\begin{tabular}{|c|c|c|c|}
\hline Palavra & Etimologia provável & Significado & Fonte \\
\hline $\begin{array}{ll}\text { 508. } & \text { Roque }^{201} \\
\text { ['roki] }\end{array}$ & $<$ Hockey & Hóquei (Esporte) & P92: 48 \\
\hline
\end{tabular}

\begin{tabular}{|l|l|l|l|}
\hline Palavra & Etimologia provável & Significado & Fonte \\
\hline Safe & $<$ Safe & Seguro, recurso usado para & D86: 174 \\
['sejf $]$ & & $\begin{array}{l}\text { parar a jogada, o jogador } \\
\text { pisa numa base que esteja }\end{array}$ & \\
& & um corredor (Esporte) & \\
& & & \\
& & & \\
& & & \\
\end{tabular}

\begin{tabular}{|l|l|l|l|}
\hline Palavra & Etimologia provável & Significado & Fonte \\
\cline { 2 - 4 } & $\begin{array}{l}\text { Seilmentu } \\
\text { [sejł'mẽtu }\end{array}$ & $\begin{array}{l}\text { Iatismo (Tecnologia e De- } \\
\text { senvolvimento) }\end{array}$ & P92: 48 \\
& & & \\
\hline
\end{tabular}

\begin{tabular}{|l|l|l|l|}
\hline Palavra & Etimologia provável & Significado & Fonte \\
\hline Shortstop & $<$ Shortstop & Interbase, posição no & EX2011: 10 \\
campo entre a segunda e & \\
[tfohtis'top] & & $\begin{array}{l}\text { terceira base (beisebol) } \\
\text { (Esporte) }\end{array}$ & \\
& & & \\
\hline
\end{tabular}

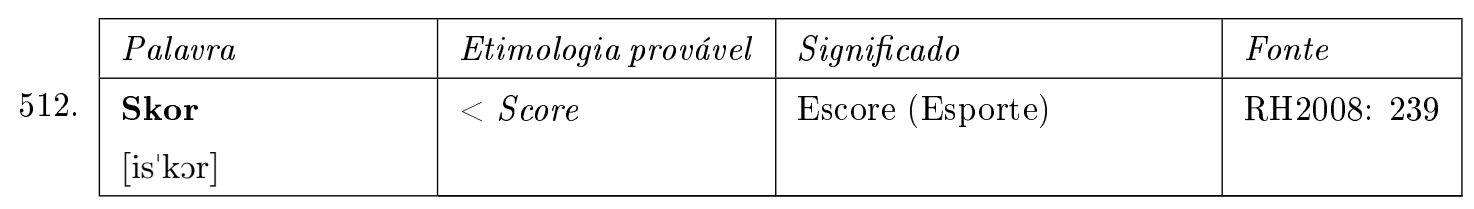

\begin{tabular}{|c|c|c|c|c|}
\hline & Palavra & Etimologia provável & Significado & Fonte \\
\hline 513. & $\begin{array}{l}\text { Skubadaifer } \\
\text { [iskuba'dajfeh] }\end{array}$ & $<$ Scuba diver & Mergulho (Esporte) & RH2008: 239 \\
\hline
\end{tabular}

\begin{tabular}{|l|l|l|l|}
\hline Palavra & Etimologia provável & Significado & Fonte \\
\hline $\begin{array}{l}\text { Slide } \\
\text { [is'lajt] }\end{array}$ & $<$ Slide & Tipo de jogada (Esporte) & D86: 175 \\
\hline
\end{tabular}

\begin{tabular}{|l|l|l|l|}
\hline Palavra & Etimologia provável & Significado & Fonte \\
\hline $\begin{array}{l}\text { Slugger } \\
{[\text { is'løgøh] }}\end{array}$ & $<$ Slugger & $\begin{array}{l}\text { Batedor que tem longo al- } \\
\text { cance (Esporte) }\end{array}$ & D86: 175 \\
\hline
\end{tabular}

201 Varia com hòki 458 .

202 Varia com zeilmentu 409. 
516.

\begin{tabular}{|l|l|l|l|}
\hline Palavra & Etimologia provável & Significado & Fonte \\
\hline $\begin{array}{l}\text { Slugging } \\
\text { [is'logĩ }]\end{array}$ & $<$ Slugging & $\begin{array}{l}\text { Quantidade de base alcan- } \\
\text { çada por um batedor (Es- } \\
\text { porte) }\end{array}$ & D86: 175 \\
\hline
\end{tabular}

\begin{tabular}{|l|l|l|l|}
\hline Palavra & Etimologia provável & Significado & Fonte \\
\hline SMS & $<$ SMS & $\begin{array}{l}\text { Sigla do inglês "Short Mes- } \\
\text { sage Service", serviço de }\end{array}$ & EX2011:04 \\
{$[$ [se'mes $]$} & & $\begin{array}{l}\text { mensagens curtas ou a pró- } \\
\text { pria mensagem (Tecnolo- } \\
\text { gia e Desenvolvimento) }\end{array}$ & \\
& & & \\
& & & \\
& & & \\
\end{tabular}

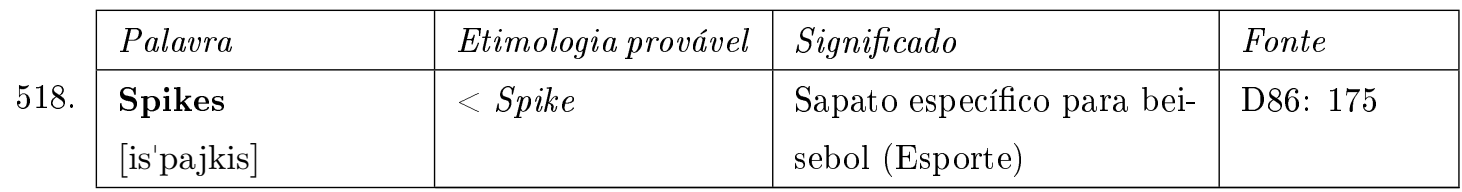

\begin{tabular}{|c|c|c|c|}
\hline Palavra & Etimologia provável & Significado & Fonte \\
\hline $\begin{array}{l}\text { Spòrt }^{203} \\
\text { [is'poht] }\end{array}$ & $<$ Sports & Esporte (Esporte) & RH2008: 244 \\
\hline
\end{tabular}

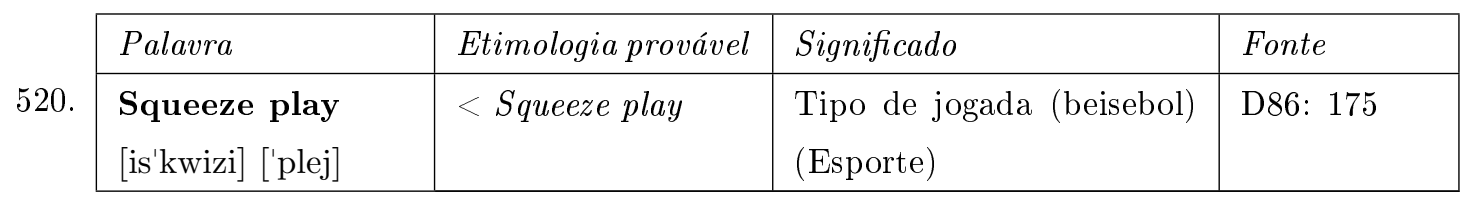

\begin{tabular}{|l|l|l|l|l|}
\hline 521. & Palavra & Etimologia provável & Significado & Fonte \\
\cline { 2 - 4 } & $\begin{array}{l}\text { Stretching } \\
\text { [istre't } \mathrm{fi}]\end{array}$ & $<$ Stretching & Alongamento (Esporte) & H44: 13 \\
\hline
\end{tabular}

\begin{tabular}{|l|l|l|l|}
\hline Palavra & Etimologia provável & Significado & Fonte \\
\hline $\begin{array}{l}\text { Supergasolin } \\
\text { [supehgaso'lí] }\end{array}$ & $<$ Super gasoline & $\begin{array}{l}\text { Gasolina de alta octana- } \\
\text { gem (Tecnologia e Desen- } \\
\text { volvimento) }\end{array}$ & $\begin{array}{l}\text { RH2008: } \\
249\end{array}$ \\
\hline
\end{tabular}

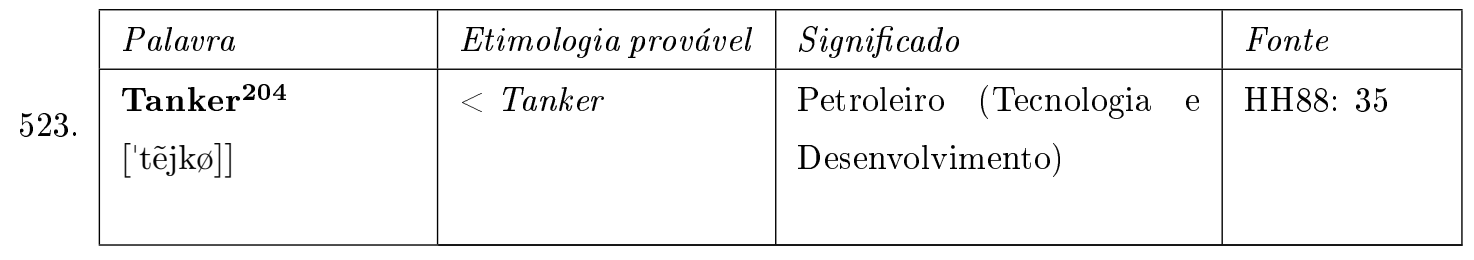

203 Varia com deporte $_{52}$ e deportivo ${ }_{54}$.

204 Varia com tènker 392. 


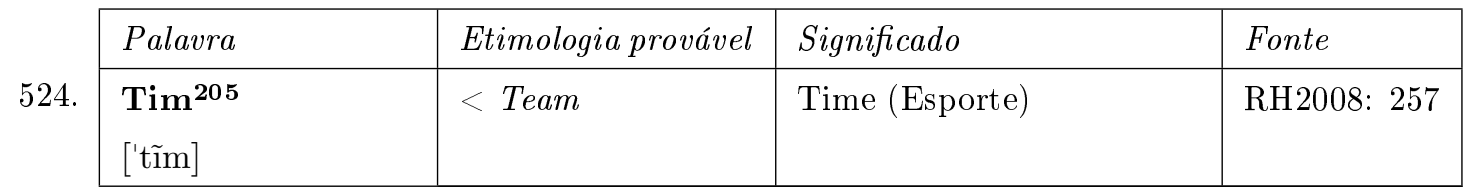

\begin{tabular}{|c|c|c|c|}
\hline Palavra & Etimologia provável & Significado & Fonte \\
\hline $\begin{array}{l}\text { Time }^{206} \\
\text { ['tajme] }\end{array}$ & $<$ Time & $\begin{array}{l}\text { Quando o juíz suspende o } \\
\text { jogo por um momento (bei- } \\
\text { sebol) (Esporte) }\end{array}$ & D86: 176 \\
\hline
\end{tabular}

\begin{tabular}{|l|l|l|l|l|}
\hline 526. & Palavra & Etimologia provável & Significado & Fonte \\
\cline { 2 - 4 } & $\begin{array}{l}\text { Treiner } \\
\text { ['trẽ̃̃neh] }\end{array}$ & $<$ Trainer & Treinador (Esporte) & RH2008: 261 \\
\cline { 2 - 4 } & & & \\
\hline
\end{tabular}

\begin{tabular}{|l|l|l|l|}
\hline Palavra & Etimologia provável & Significado & Fonte \\
\cline { 2 - 4 } & $\begin{array}{l}\text { Triple play } \\
\text { ['triple] ['plej] }\end{array}$ & $\begin{array}{l}\text { Tipo de jogada (beisebol) } \\
\text { (Esporte) }\end{array}$ & D86: 176 \\
\hline
\end{tabular}

\begin{tabular}{|l|l|l|l|}
\hline Palavra & Etimologia provável & Significado & Fonte \\
\hline Twitter & $<$ Twitter & Twitter é uma rede social & EX2011: 04 \\
['twiteh] & & $\begin{array}{c}\text { e servidor para microblog- } \\
\text { ging, que permite aos usuá- }\end{array}$ & \\
& & rios enviar e receber atua- & \\
& & lizações pessoais de outros & \\
& & contatos por meio do web- & \\
& & site do serviço (Tecnologia & \\
& & e Desenvolvimento) & \\
& & & \\
\hline
\end{tabular}

\begin{tabular}{|c|c|c|c|}
\hline Palavra & Etimologia provável & Significado & Fonte \\
\hline $\begin{array}{l}\text { Umpire } \\
\text { [ẽm'pajre] }\end{array}$ & $<$ Umpire & $\begin{array}{l}\text { Árbitro do jogo de beisebol } \\
\text { (Esporte) }\end{array}$ & D86: 176 \\
\hline
\end{tabular}

\begin{tabular}{|l|l|l|l|}
\hline Palavra & Etimologia provável & Significado & Fonte \\
\hline 530. & $\begin{array}{l}\text { Wild pitch } \\
\text { ['wajlt] ['pitfi] }\end{array}$ & $\begin{array}{l}\text { Lançamento que não é } \\
\text { pego (beisebol) (Esporte) }\end{array}$ & D86: 177 \\
\hline
\end{tabular}

205 Varia com time $_{525}$.

206 Varia com tim $_{524}$.

207 Varia com entrenadós e adiestradó $_{2}$. 


\begin{tabular}{|l|l|l|l|}
\hline Palavra & Etimologia provável & Significado & Fonte \\
\hline Windsurf & $<$ Windsurf & Windsurfe, esporte que & P92: 26 \\
[wit'səhf] & & $\begin{array}{l}\text { consiste em se deslocar } \\
\text { na água, de pé sobre }\end{array}$ & \\
& & uma prancha semelhante à & \\
& & usada no surfe, porém mu- \\
& & & \\
& & & \\
\end{tabular}

\begin{tabular}{|l|l|l|l|}
\hline Palavra & Etimologia provável & Significado & Fonte \\
\hline Youtube & $<$ Youtube & $\begin{array}{l}\text { Youtube é um site que per- } \\
\text { mite que seus usuários car- } \\
\text { [ju'tube }]\end{array}$ & $\begin{array}{l}\text { EX2011:05 } \\
\text { reguem e compartilhem ví- } \\
\text { deos em formato digital } \\
\text { (Tecnologia e Desenvolvi- } \\
\end{array}$ \\
& & $\begin{array}{l} \\
\text { mento) }\end{array}$ & \\
\hline
\end{tabular}

533.

\begin{tabular}{|l|l|l|l|}
\hline Palavra & Etimologia provável & Significado & Fonte \\
\hline Zip code & $<$ Zip code & Código postal (Tecnologia & RH2008: \\
['zip] ['kowdi] & & e Desenvolvimento) & 283 \\
& & & \\
\hline
\end{tabular}

\section{ESPANHOL/PORTUGUÊS}

\begin{tabular}{|l|l|l|l|}
\hline 534. & Etimologia provável & Significado & Fonte \\
\cline { 2 - 4 } & $\begin{array}{l}\text { Adishonal } \\
\text { [adifo'nał }]\end{array}$ & Adicional (Economia) & RH2008: 03 \\
\hline
\end{tabular}

\begin{tabular}{|l|l|l|l|}
\hline Palavra & Etimologia provável & Significado & Fonte \\
\hline $\begin{array}{l}\text { Adishonalmente } \\
\text { [adifonał'mẽte] }\end{array}$ & $<$ Adicionalmente & $\begin{array}{l}\text { Adicional-mente (Econo- } \\
\text { mia) }\end{array}$ & RH2008: 03 \\
& & & \\
\hline
\end{tabular}

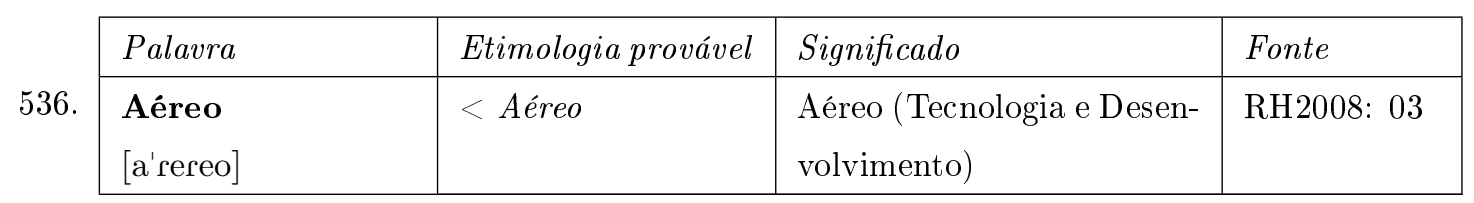

\begin{tabular}{|l|l|l|l|}
\hline Palavra & Etimologia provável & Significado & Fonte \\
\hline Aereodinámika & $<$ Aerodinâmica & Aerodinâ-mica (Tecnologia & RH2008: 03 \\
[arerjodi'nãmika] & $\mathrm{PT} /$ Aerodinámica \\
& ESP & e Desenvolvimento) & \\
\hline
\end{tabular}




\begin{tabular}{|l|l|l|l|}
\hline Palavra & Etimologia provável & Significado & Fonte \\
\hline Aerodinámi- & $<$ Aerodinamica- & Aerodinamicamente & RH2008: 03 \\
kamente & mente PT / Ae- & (Tecnologia e Desenvolvi- & \\
[arjodinãmika'mẽte] $]$ & $\begin{array}{l}\text { rodinámicamente } \\
\text { ESP }\end{array}$ & mento) & \\
\hline
\end{tabular}

539.

\begin{tabular}{|l|l|l|l|}
\hline Palavra & Etimologia provável & Significado & Fonte \\
\hline Aerodinámiko & $<$ Aerodinâmico & Aerodinâmi-co (Tecnologia & RH2008: 03 \\
[axerodi'nãmiko] & $\begin{array}{l}\mathrm{PT} / \text { Aerodinámico } \\
\text { ESP }\end{array}$ & e Desenvolvimento) & \\
\hline
\end{tabular}

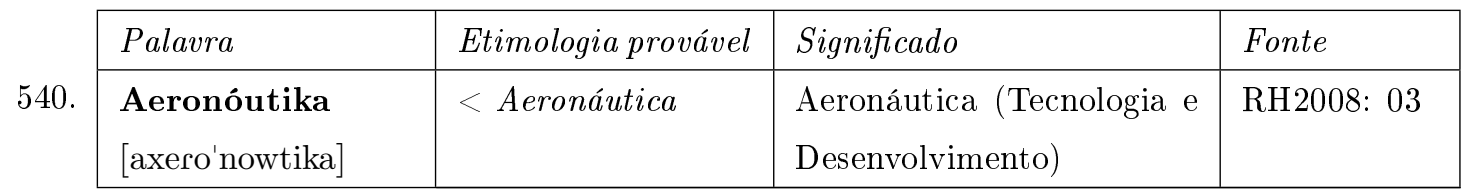

\begin{tabular}{|c|c|c|c|c|}
\hline \multirow[b]{2}{*}{541.} & Palavra & Etimologia provável & Significado & Fonte \\
\hline & $\begin{array}{l}\text { Aeronouto } \\
\text { [areo'nowto] }\end{array}$ & $\longleftarrow$ Aeronauta & $\begin{array}{l}\text { Aeronauta (Tecnologia e } \\
\text { Desenvolvimento) }\end{array}$ & RH2008: 03 \\
\hline \multirow[b]{2}{*}{542.} & Palavra & Etimologia provável & Significado & Fonte \\
\hline & $\begin{array}{l}\text { Aeroplano }^{208} \\
\text { [areo'plãno] }\end{array}$ & $<$ Aeroplano & $\begin{array}{l}\text { Avião (Tecnologia e Desen- } \\
\text { volvimento) }\end{array}$ & RH2008: 03 \\
\hline
\end{tabular}

\begin{tabular}{|c|c|c|c|}
\hline Palavra & Etimologia provável & Significado & Fonte \\
\hline $\begin{array}{l}\text { Afisionado } \\
\text { [a'fisionado] }\end{array}$ & $<$ Aficionado & Aficionado (Esporte) & D86: 162 \\
\hline
\end{tabular}

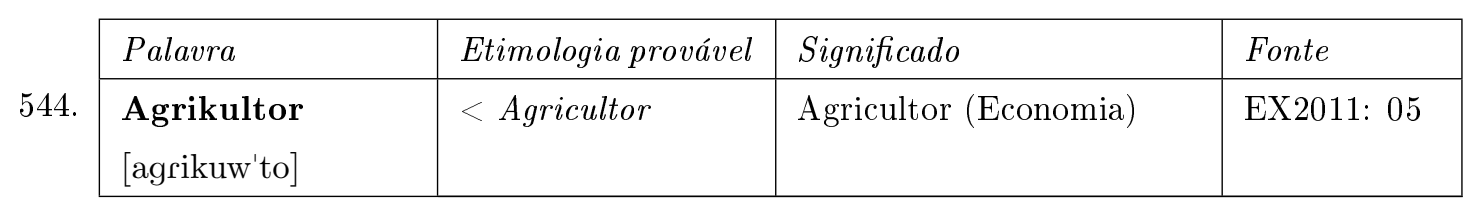

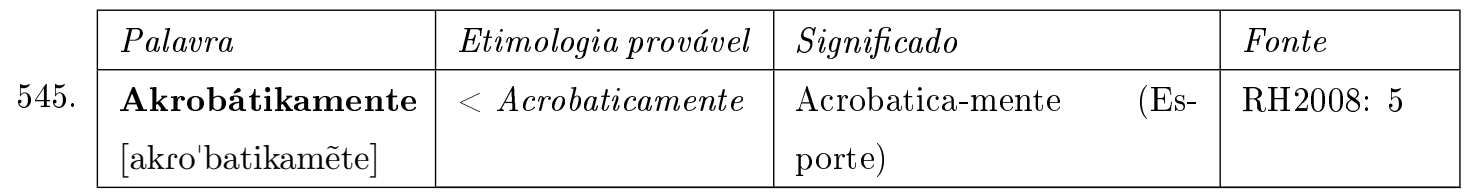

\begin{tabular}{|l|l|l|l|l|}
\hline 546. & Palavra & Etimologia provável & Significado & Fonte \\
\cline { 1 - 4 } & $\begin{array}{l}\text { Akrobátiko } \\
\text { [akro'batiku }]\end{array}$ & $<$ Acrobático & Acrobático (Esporte) & RH2008: 5 \\
\cline { 2 - 4 }
\end{tabular}

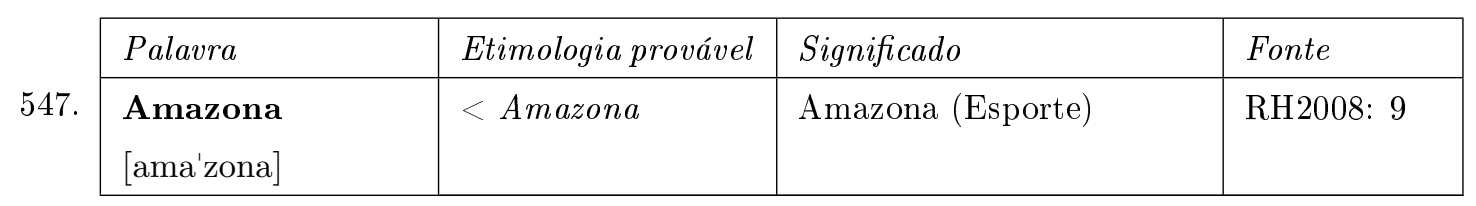

208 Varia com avioneta ${ }_{28}$, oroplano ${ }_{766}$ e avion $_{27}$. 


\begin{tabular}{|c|c|c|c|c|}
\hline \multirow[b]{2}{*}{548.} & Palavra & Etimologia provável & Significado & Fonte \\
\hline & $\begin{array}{l}\text { Antena } \\
{\left[\tilde{a}^{\prime} t e ̃ n a\right]}\end{array}$ & $<$ Antena & $\begin{array}{l}\text { Antena (Tecnologia e De- } \\
\text { senvolvimento) }\end{array}$ & RH2008: 03 \\
\hline \multirow[b]{2}{*}{549.} & Palavra & Etimologia provável & Significado & Fonte \\
\hline & $\begin{array}{l}\text { Antesala } \\
{[\text { ãte'sala }]}\end{array}$ & $\begin{array}{l}<\text { Ante-sala } \mathrm{PT} / \\
\text { Antesala } \mathrm{ESP}\end{array}$ & $\begin{array}{l}\text { Nome dado ao jogador de } \\
3^{\mathrm{a}} \text { base (Esporte) }\end{array}$ & D86: 162 \\
\hline \multirow[b]{2}{*}{550.} & Palavra & Etimologia provável & Significado & Fonte \\
\hline & $\begin{array}{l}\text { Anunsio } \\
\text { [a'nũsio] }\end{array}$ & $\begin{array}{l}<\text { Anúncio PT } / \\
\text { Anuncio ESP }\end{array}$ & $\begin{array}{l}\text { Anúncio (Tecnologia e De- } \\
\text { senvolvimento) }\end{array}$ & $\begin{array}{l}\text { RH2008: } \\
177\end{array}$ \\
\hline \multirow[b]{2}{*}{551.} & Palavra & Etimologia provável & Significado & Fonte \\
\hline & $\begin{array}{l}\text { Aporte }^{209} \\
\text { [a'pohte] }\end{array}$ & $<$ Aporte & $\begin{array}{l}\text { Aporte, subsídio (Econo- } \\
\text { mia) }\end{array}$ & EX2011: 03 \\
\hline
\end{tabular}

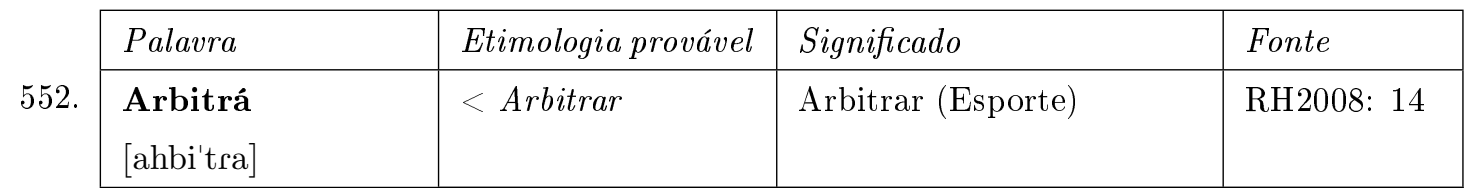

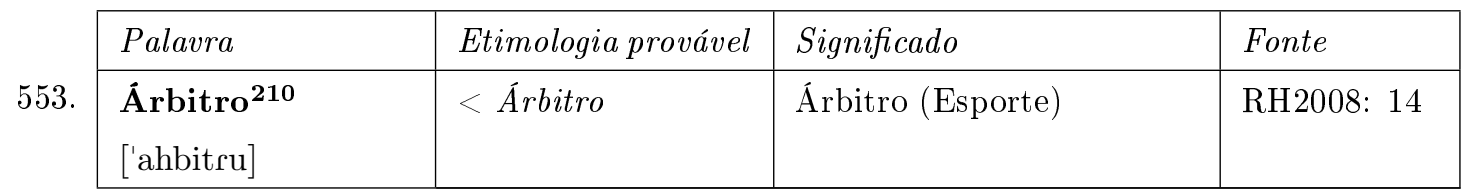

\begin{tabular}{|l|l|l|l|}
\hline Palavra & Etimologia provável & Significado & Fonte \\
\cline { 2 - 4 } & $\begin{array}{l}\text { Arko } \\
{[\text { 'ahko] }}\end{array}$ & Arco (Esporte) & RH2008: 15 \\
\hline
\end{tabular}

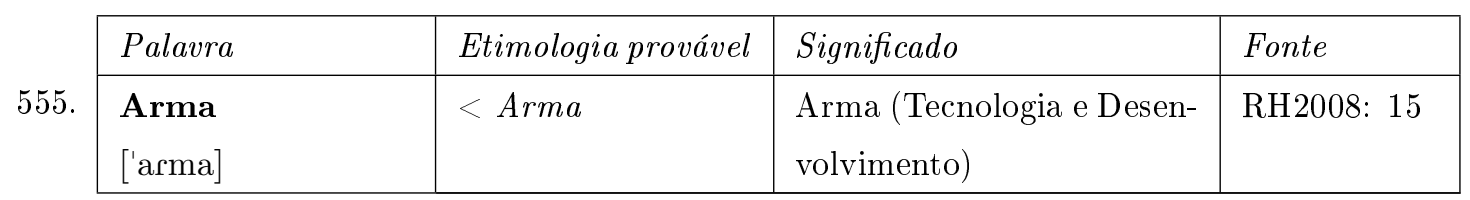

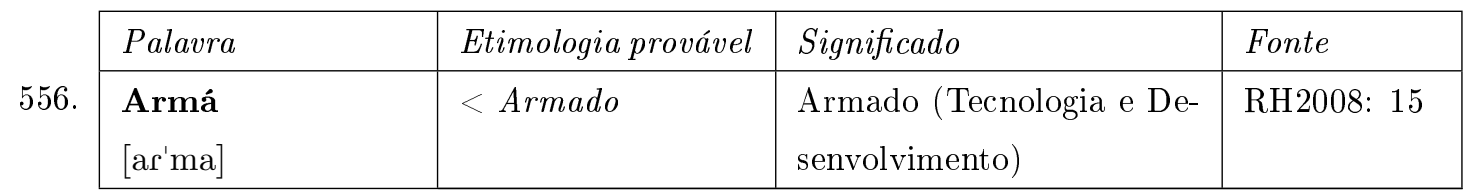

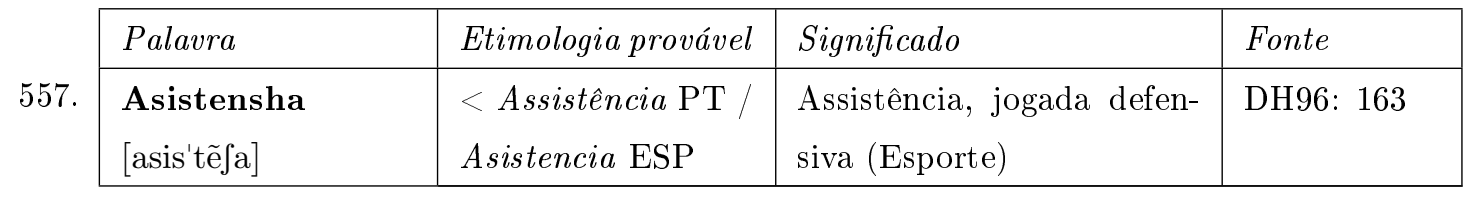

209 Varia com supsidio 844 .

210 Varia com arbitradó 19 e rèfri $i_{221}$. 


\begin{tabular}{|l|l|l|l|l|}
\hline 558. & Palavra & Etimologia provável & Significado & Fonte \\
\cline { 2 - 5 } & Asistensia & $<$ Assistência PT / & Assistência (Tecnologia e & EX2011: 09 \\
[asis'tẽsia] & Asistencia ESP & Desenvolvimento) & \\
\hline
\end{tabular}

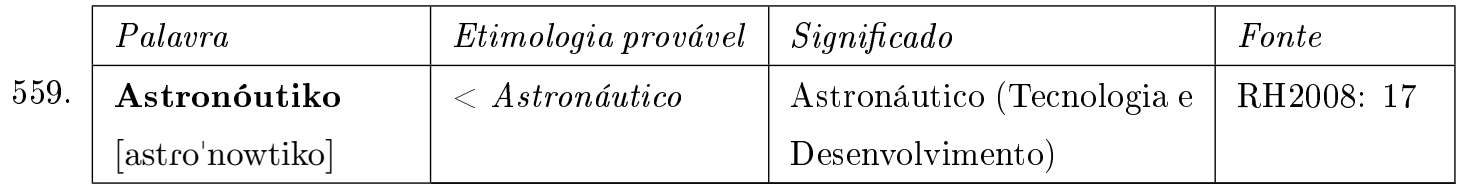

\begin{tabular}{|l|l|l|l|}
\hline 560. & Etimologia provável & Significado & Fonte \\
\cline { 2 - 5 } $\begin{array}{l}\text { Atakante } \\
\text { [ata'kãte] }\end{array}$ & $<$ Atacante & Atacante (Esporte) & H44: 29 \\
\hline
\end{tabular}

\begin{tabular}{|l|l|l|l|}
\hline 561. & Etimologia provável & Significado & Fonte \\
\cline { 2 - 5 } $\begin{array}{l}\text { Atleta } \\
\text { [a'tleta] }\end{array}$ & $<$ Atleta & Atleta (Esporte) & RH2008: 17 \\
\hline
\end{tabular}

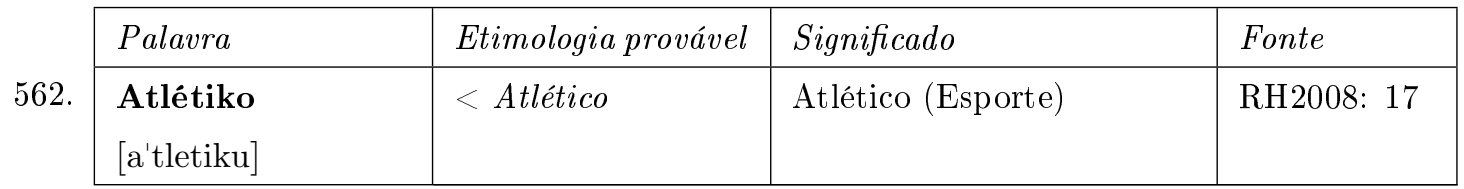

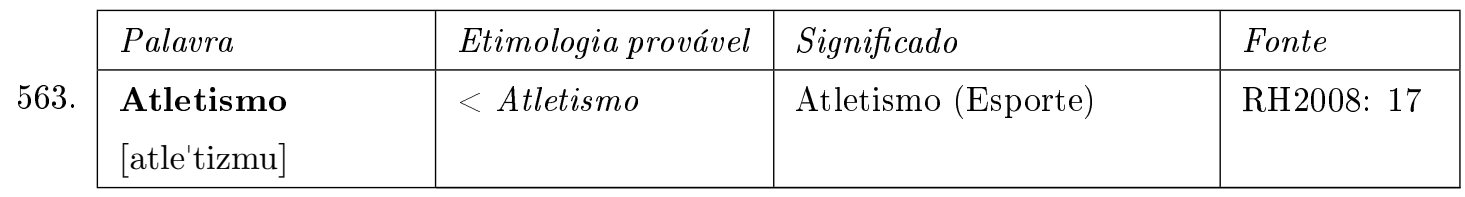

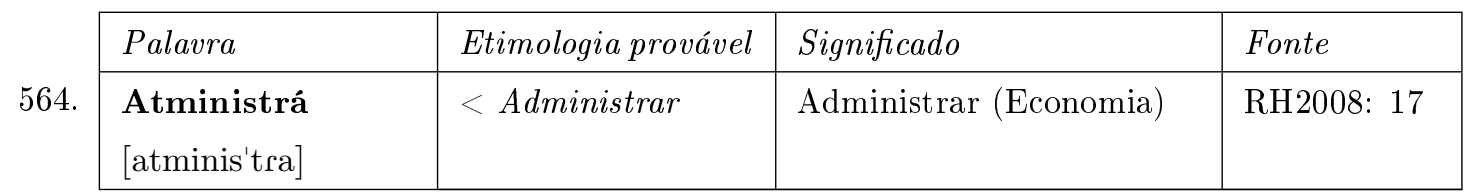

\begin{tabular}{|l|l|l|l|}
\hline Palavra & Etimologia provável & Significado & Fonte \\
\hline 565. Atministrabel & $<$ Administrável \\
[atminis'trabel $]$ & Adminis-trável (Econo- & RH2008: 17 \\
& ESP / Administrable & mia) & \\
\hline
\end{tabular}

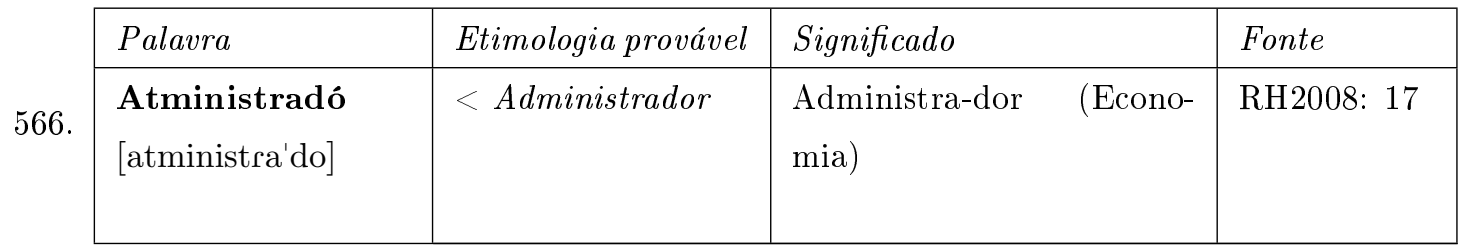

\begin{tabular}{|l|l|l|l|}
\hline Palavra & Etimologia provável & Significado & Fonte \\
\hline Atministrativa- & $<$ Administrati- & Administrati-vamente & RH2008: 18 \\
mente & vamente PT / & (Economia) \\
[atministratifa'mẽte] & Administrativami- & & \\
& ente ESP & & \\
\hline
\end{tabular}


568.

\begin{tabular}{|l|l|l|l|}
\hline Palavra & Etimologia provável & Significado & Fonte \\
\hline $\begin{array}{l}\text { Atministrativo } \\
\text { [atministra'tifo] }\end{array}$ & $<$ Administrativo & $\begin{array}{l}\text { Administrativo (Econo- } \\
\text { mia) }\end{array}$ & RH2008: 18 \\
& & & \\
\hline
\end{tabular}

569.

\begin{tabular}{|l|l|l|l|}
\hline Palavra & Etimologia provável & Significado & Fonte \\
\hline $\begin{array}{l}\text { Atómiko } \\
\text { [a'tõmiko] }\end{array}$ & $\begin{array}{l}<\text { Atômico PT / } \\
\text { Atómico ESP }\end{array}$ & $\begin{array}{l}\text { Atômico (Tecnologia e De- } \\
\text { senvolvimento) }\end{array}$ & RH2008: 18 \\
\hline
\end{tabular}

570.

\begin{tabular}{|l|l|l|l|}
\hline Palavra & Etimologia provável & Significado & Fonte \\
\hline $\begin{array}{l}\text { Atversario } \\
\text { [atfer'sario] }\end{array}$ & $\begin{array}{l}\text { PT Adversário, adversario, a } \\
\text { ESP }\end{array}$ & Adversário (Esporte) & H44: 29 \\
& ES Ad & \\
\hline
\end{tabular}

571.

\begin{tabular}{|l|l|l|l|}
\hline Palavra & Etimologia provável & Significado & Fonte \\
\hline $\begin{array}{l}\text { Aviador } \\
\text { [afia'do }]\end{array}$ & $<$ Aviador & $\begin{array}{l}\text { Aviador (Tecnologia e De- } \\
\text { senvolvimento) }\end{array}$ & RH2008: 18 \\
\hline
\end{tabular}

572.

\begin{tabular}{|l|l|l|l|}
\hline Palavra & Etimologia provável & Significado & Fonte \\
\hline $\begin{array}{l}\text { Bakarat } \\
\text { [baka'rat] }\end{array}$ & $<$ Bacará & Jogo de cartas (Esporte) & RH2008: 21 \\
\hline
\end{tabular}

573.

\begin{tabular}{|l|l|l|l|}
\hline Palavra & Etimologia provável & Significado & Fonte \\
\hline Banko & $<$ Banco & Banco (financeiro) (Econo- & RH2008: 23 \\
['bãko] & mia) & \\
& & & \\
\hline
\end{tabular}

574.

\begin{tabular}{|lr|l|l|l|}
\hline Palavra & & Etimologia provável & Significado & Fonte \\
\hline $\begin{array}{l}\text { Bapor di } \\
\text { troli }\end{array}$ pe- & $<$ Vapor de petróleo & Navio-tanque (Tecnologia & RH2008: 33 \\
{$\left[\begin{array}{l}\text { ba'por }] \\
\text { [pe'troli }]\end{array}\right.$} & {$[\mathrm{di}]$} & & Desenvolvimento) & \\
\hline
\end{tabular}

575 .

\begin{tabular}{|l|l|l|l|}
\hline Palavra & Etimologia provável & Significado & Fonte \\
\hline $\begin{array}{l}\text { Bapor di zeta }{ }^{213} \\
\text { [ba'poh] [di] ['zeta] }\end{array}$ & $\begin{array}{l}<\text { Vapor de azeite } \\
\mathrm{PT} \mathrm{/} \mathrm{Vapor} \mathrm{de} \\
\text { aceite ESP }\end{array}$ & $\begin{array}{l}\text { Navio-tanque (Tecnologia } \\
\text { e Desenvolvimento) }\end{array}$ & RH2008: 33 \\
\hline
\end{tabular}

${ }^{211}$ Varia com bará di karta $a_{31}$ e baraha di karta $a_{33}$.

212 Varia com bapor di zeta $a_{575}$.

${ }^{213}$ Varia com bapor di petroli ${ }_{574}$. 


\begin{tabular}{|l|l|l|l|}
\hline Palavra & Etimologia provável & Significado & Fonte \\
\hline Base & $<$ Base & Um dos quatro pontos que & D86: 163 \\
& & $\begin{array}{l}\text { devem ser tocados, por or- } \\
\text { dem, pelo corredor para } \\
\end{array}$ & \\
& & marcar pontos (Esporte) & \\
\hline
\end{tabular}

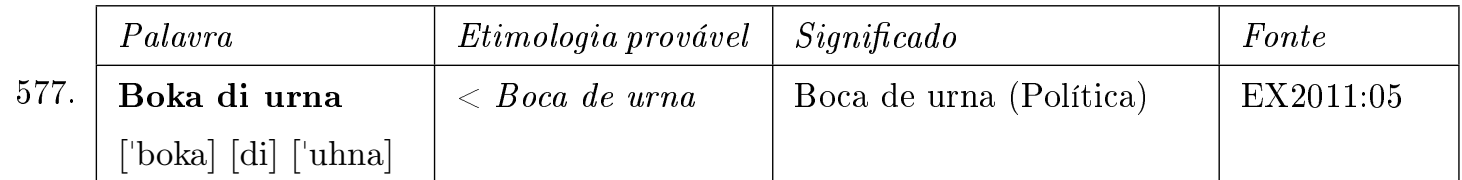

\begin{tabular}{|l|l|l|l|}
\hline 578. & Etimologia provável & Significado & Fonte \\
\cline { 2 - 4 } & $\begin{array}{l}\text { Bòksdó } \\
{[\text { bokisi'do }]}\end{array}$ & Pugilista (Esporte) & RH2008: 32 \\
\hline
\end{tabular}

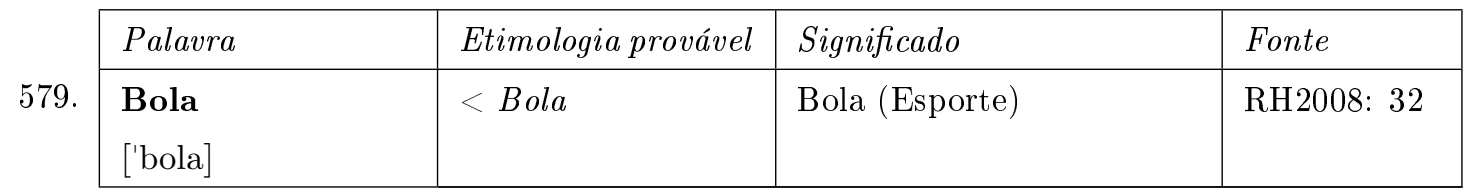

\begin{tabular}{|c|c|c|c|c|}
\hline & Palavra & Etimologia provável & Significado & Fonte \\
\hline 580. & $\begin{array}{l}\text { Bombardiá } \\
\text { [bõbahdi'a] }\end{array}$ & $<$ Bombardear & $\begin{array}{l}\text { Bombardear (Tecnologia e } \\
\text { Desenvolvimento) }\end{array}$ & RH2008: 33 \\
\hline
\end{tabular}

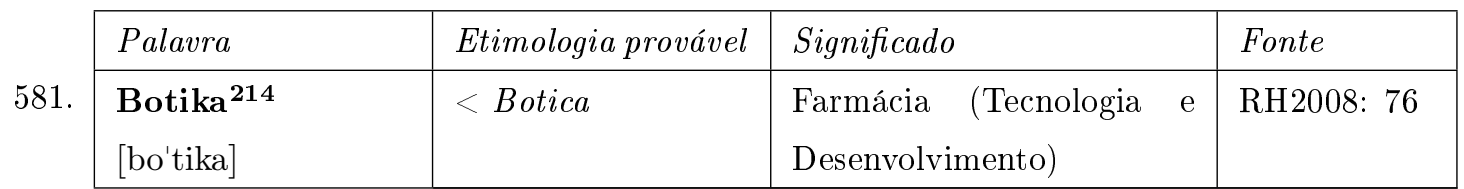

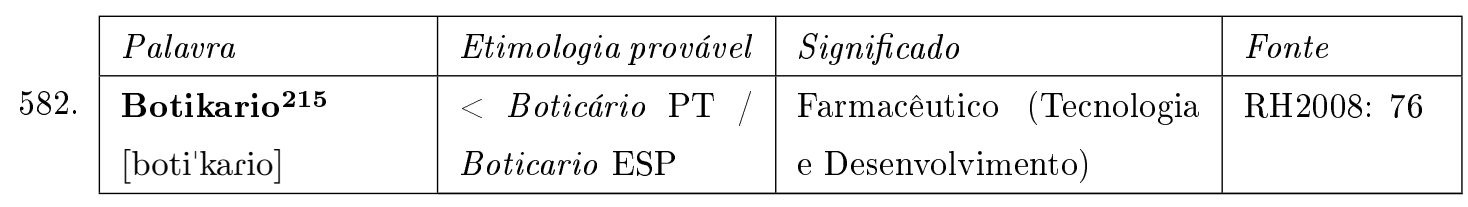

\begin{tabular}{|l|l|l|l|}
\hline 583. & Etimologia provável & Significado & Fonte \\
\hline $\begin{array}{l}\text { Boto di motor } \\
{[\text { 'boto] }[\mathrm{di}][\mathrm{mo} \text { toh }]}\end{array}$ & $\Leftarrow$ Bote / $<$ Motor & Barco a motor (Esporte) & P92: 48 \\
\hline
\end{tabular}

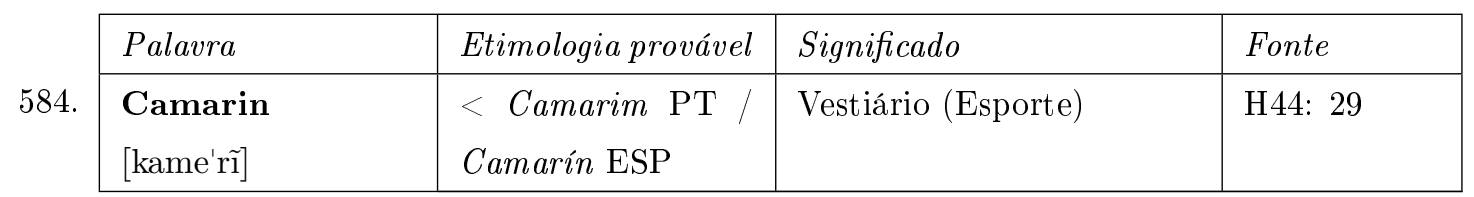

\begin{tabular}{|l|l|l|l|}
\hline Palavra & Etimologia provável & Significado & Fonte \\
\cline { 2 - 4 } & $\begin{array}{l}\text { Cónsul } \\
\text { ['kõsuł] }\end{array}$ & $\begin{array}{l}\text { Cónsul PT ESP } \\
\text { Cónul Eônsul }\end{array}$ & H44: 8 \\
\hline
\end{tabular}

214 Varia com farmasia $_{625}$.

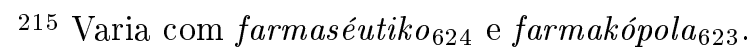




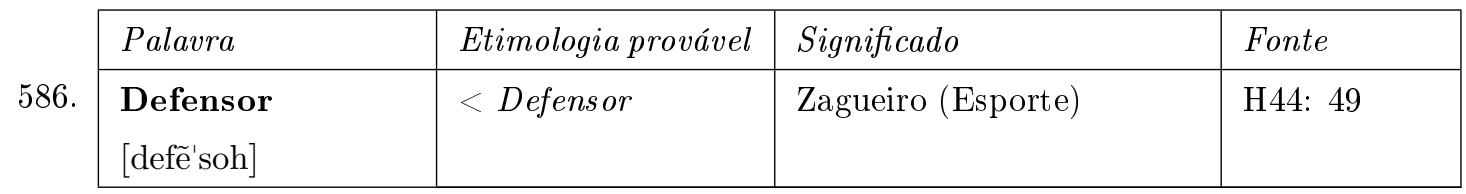

\begin{tabular}{|l|l|l|l|}
\hline 587. & Etimologia provável & Significado & Fonte \\
\cline { 2 - 4 } & $\begin{array}{l}\text { Défisit } \\
\text { [defi'si }]\end{array}$ & Déficit (Economia) & RH2008: 46 \\
\hline
\end{tabular}

\begin{tabular}{|c|c|c|c|c|}
\hline & Palavra & Etimologia provável & Significado & Fonte \\
\hline 588. & $\begin{array}{l}\text { Desarmá } \\
\text { [desah'ma] }\end{array}$ & $<$ Desarmar & $\begin{array}{l}\text { Desarmar (Tecnologia e } \\
\text { Desenvolvimento) }\end{array}$ & RH2008: 51 \\
\hline
\end{tabular}

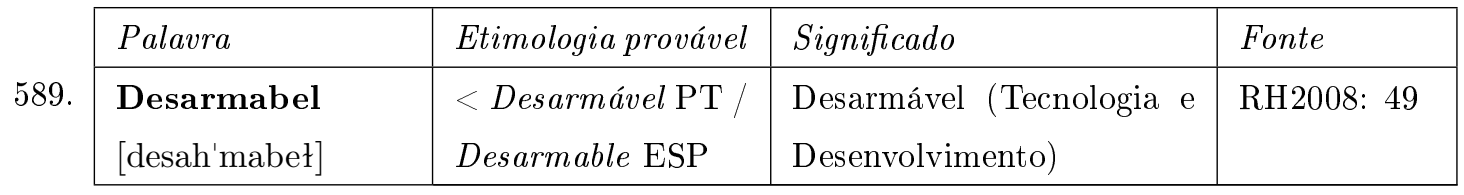

590.

\begin{tabular}{|l|l|l|l|}
\hline Palavra & Etimologia provável & Significado & Fonte \\
\hline $\begin{array}{l}\text { Desarmamentu } \\
\text { [desahma'mẽtu] }\end{array}$ & $\begin{array}{l}<\text { Desarmamento } \\
\text { PTto ESP }\end{array}$ & $\begin{array}{l}\text { Desarma-mento (Tecnolo- } \\
\text { entormami- }\end{array}$ & Ria e Desenvolvimento) \\
\hline
\end{tabular}

\begin{tabular}{|l|l|l|l|}
\hline Palavra & Etimologia provável & Significado & Fonte \\
\hline 591. & $<$ Descontrolar & Momento em que o jogador & RH2008: 48 \\
[deskõtro'la] & & $\begin{array}{l}\text { não pode fazer "strike" } \\
\text { (beisebol) (Esporte) }\end{array}$ & \\
& & & \\
\hline
\end{tabular}

\begin{tabular}{|l|l|l|l|l|}
\hline Palavra & Etimologia provável & Significado & Fonte \\
\hline Desponibel & $\begin{array}{l}<\text { Disponivel PT / } \\
\text { Disponible ESP } \\
\text { [despo'nibeł }]\end{array}$ & $\begin{array}{l}\text { Descartável, disponível (fi- } \\
\text { nanças) (Economia) }\end{array}$ & RH2008: 52 \\
\hline \begin{tabular}{|l|l|l|l|}
\hline Palavra & Etimologia provável & Significado & Fonte \\
\hline $\begin{array}{l}\text { Detoná } \\
\text { [detõ'na }]\end{array}$ & $\begin{array}{l}\text { Detonar (Tecnologia e De- } \\
\text { senvolvimento) }\end{array}$ & RH2008: 52 \\
\hline
\end{tabular}
\end{tabular}

\begin{tabular}{|l|l|l|l|}
\hline Palavra & Etimologia provável & Significado & Fonte \\
\hline $\begin{array}{l}\text { Distribuidor } \\
\text { [distribi'do] }\end{array}$ & $<$ Distribuidor & Distribuidor (Economia) & EX2011: 04 \\
\hline
\end{tabular}

\begin{tabular}{|l|l|l|l|}
\hline 595. & Etimologia provável & Significado & Fonte \\
\cline { 2 - 4 } & $\begin{array}{l}\text { Dominó } \\
\text { [domĩ'no] }\end{array}$ & Dominó (Esporte) & H44: 29 \\
\hline
\end{tabular}




\begin{tabular}{|l|l|l|l|}
\hline Palavra & Etimologia provável & Significado & Fonte \\
\hline Ekonométriko & $<$ Econométrico & Economé-trico, relativo ao & EX2011: 03 \\
[ekono'metriko] & & $\begin{array}{l}\text { método estatístico de aná- } \\
\text { lise de dados e problemas } \\
\end{array}$ & \\
& & & \\
& & & \\
\hline
\end{tabular}

\begin{tabular}{|l|l|l|l|}
\hline 597. & Etimologia provável & Significado & Fonte \\
\hline $\begin{array}{l}\text { Ekonomia } \\
\text { [ekõno'mia }]\end{array}$ & $<$ Economia & Economia (Economia) & RH2008: 64 \\
\hline
\end{tabular}

\begin{tabular}{|c|c|c|c|c|}
\hline & Palavra & Etimologia provável & Significado & Fonte \\
\hline 598. & $\begin{array}{l}\text { Ekonómiko } \\
\text { [ekõ'nõmiko] }\end{array}$ & $\begin{array}{l}<\text { Econômico } \mathrm{PT} / \\
\text { Económico } \mathrm{ESP}\end{array}$ & Econômico (Economia) & RH2008: 64 \\
\hline
\end{tabular}

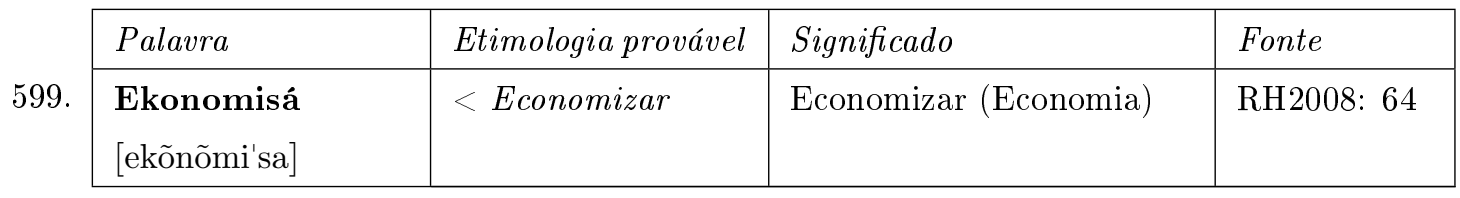

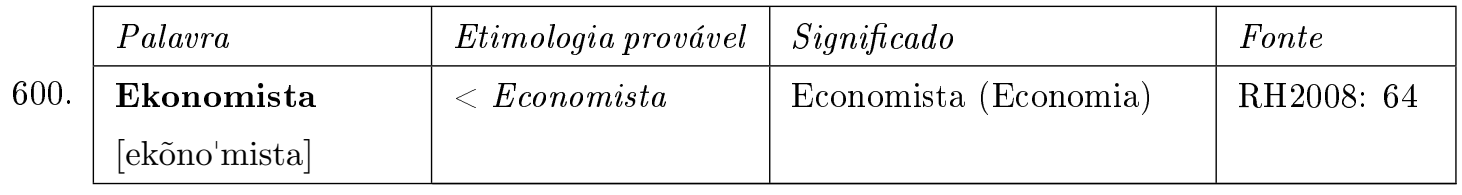

\begin{tabular}{|l|l|l|l|}
\hline 601. & Etimologia provável & Significado & Fonte \\
\cline { 2 - 4 } & $\begin{array}{l}\text { Eksplosivo } \\
\text { [ekisplo'sifo] }\end{array}$ & $\begin{array}{l}\text { Explosivo (Tecnologia e } \\
\text { Desenvolvimento) }\end{array}$ & RH2008: 65 \\
\hline
\end{tabular}

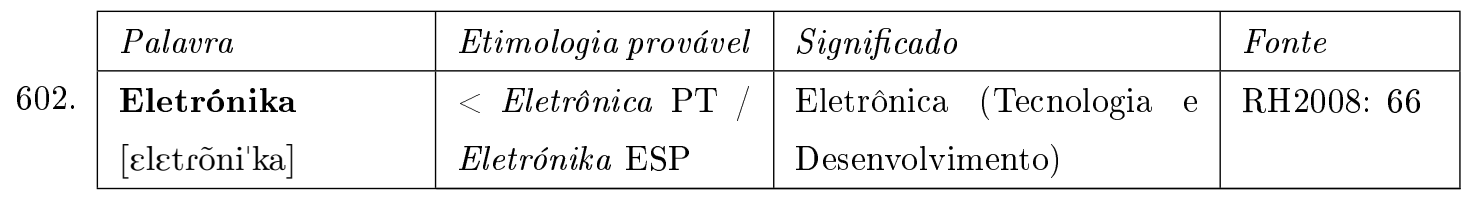

603.

\begin{tabular}{|l|l|l|l|}
\hline Palavra & Etimologia provável & Significado & Fonte \\
\hline $\begin{array}{l}\text { Eletrónikamente } \\
\text { [Eletrõnika'mẽte] }\end{array}$ & $\begin{array}{l}<\text { Eletronicamente } \\
\text { PT / Eletrónika- }\end{array}$ & Eletronica-mente (Tecno- & RH2008: 66 \\
& logia e Desenvolvimento) & \\
\hline
\end{tabular}

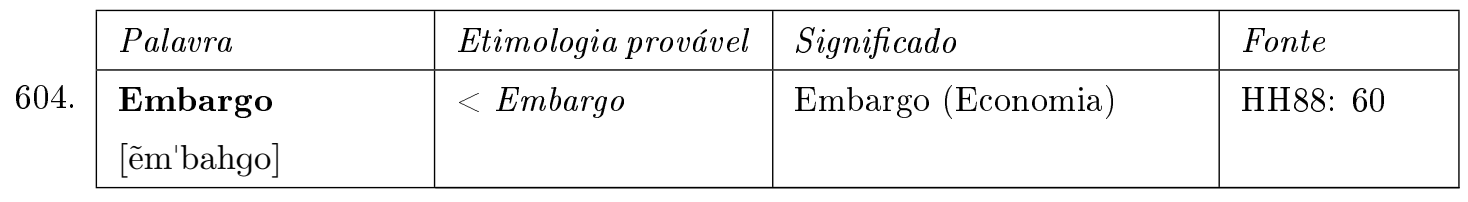




\begin{tabular}{|l|l|l|l|}
\hline Palavra & Etimologia provável & Significado & Fonte \\
\hline Emergente & $<$ Emergente & $\begin{array}{l}\text { Jogador que entra no lugar } \\
\text { do outro no beisebol (Es- } \\
\text { porte) }\end{array}$ & D86: 166 \\
& & & \\
\hline
\end{tabular}

\begin{tabular}{|c|c|c|c|c|}
\hline & Palavra & Etimologia provável & Significado & Fonte \\
\hline 606. & $\begin{array}{l}\text { Emisor } \\
\text { [emi'soh] }\end{array}$ & $\begin{array}{l}<\text { Emissor } \mathrm{PT} / \\
\text { Emisor ESP }\end{array}$ & $\begin{array}{l}\text { Estação de rádio (Tecnolo- } \\
\text { gia e Desenvolvimento) }\end{array}$ & RH2008: 67 \\
\hline
\end{tabular}

\begin{tabular}{|c|c|c|c|c|}
\hline \multirow[b]{2}{*}{607.} & Palavra & Etimologia provável & Significado & Fonte \\
\hline & $\begin{array}{l}\text { Emisora } \\
\text { [emi'sora] }\end{array}$ & $\begin{array}{l}<\text { Emissora PT / } \\
\text { Emisora ESP }\end{array}$ & $\begin{array}{l}\text { Estação de radiodifusão } \\
\text { (Tecnologia e Desenvolvi- } \\
\text { mento) }\end{array}$ & RH2008: 67 \\
\hline \multirow[b]{2}{*}{608.} & Palavra & Etimologia provável & Significado & Fonte \\
\hline & $\begin{array}{l}\text { Emiti } \\
{[\text { emi'ti] }}\end{array}$ & $<$ Emitido & $\begin{array}{l}\text { Transmitido (Tecnologia e } \\
\text { Desenvolvimento) }\end{array}$ & RH2008: 67 \\
\hline
\end{tabular}

\begin{tabular}{|c|c|c|c|c|}
\hline \multirow[b]{2}{*}{609.} & Palavra & Etimologia provável & Significado & Fonte \\
\hline & $\begin{array}{l}\text { Empatá } \\
\text { [ẽmpa'ta] }\end{array}$ & $<$ Empatar & Empatar (Esporte) & D86: 166 \\
\hline \multirow[b]{2}{*}{610.} & Palavra & Etimologia provável & Significado & Fonte \\
\hline & $\begin{array}{l}\text { Emprendé } \\
{\left[\tilde{e} m p r e \tilde{e}^{\prime} \mathrm{de}\right]}\end{array}$ & $\begin{array}{l}<\text { Empreender } \mathrm{PT} \\
/ \text { Emprender } \mathrm{ESP}\end{array}$ & Empreender (Economia) & RH2008: 68 \\
\hline
\end{tabular}

\begin{tabular}{|c|c|c|c|c|}
\hline \multirow[b]{2}{*}{611.} & Palavra & Etimologia provável & Significado & Fonte \\
\hline & $\begin{array}{l}\text { Emprendedó } \\
\text { [ẽmprẽde'do] }\end{array}$ & $\begin{array}{l}<\quad \text { Empreendedor } \\
\text { PT / Emprendedor } \\
\text { ESP }\end{array}$ & Empreende-dor & RH2008: 68 \\
\hline \multirow[b]{2}{*}{612.} & Palavra & Etimologia provável & Significado & Fonte \\
\hline & $\begin{array}{l}\text { Empresa } \\
{[\tilde{1} \mathrm{~m} \text { 'presa] }}\end{array}$ & $<$ Empresa & Empresa (Economia) & RH2008: 68 \\
\hline
\end{tabular}

\begin{tabular}{|l|l|l|l|}
\hline Palavra & Etimologia provável & Significado & Fonte \\
\hline Empresa fune- & $<$ Empresa, Fune- & Casa funerária (Economia) & RH2008: 68 \\
raro & rária PT / Funera- & & \\
{$[$ ĩm'presa $]$} & ria ESP & & \\
{$[$ func'raro $]$} & & & \\
\hline
\end{tabular}

216 Varia com entreprenur 282. 


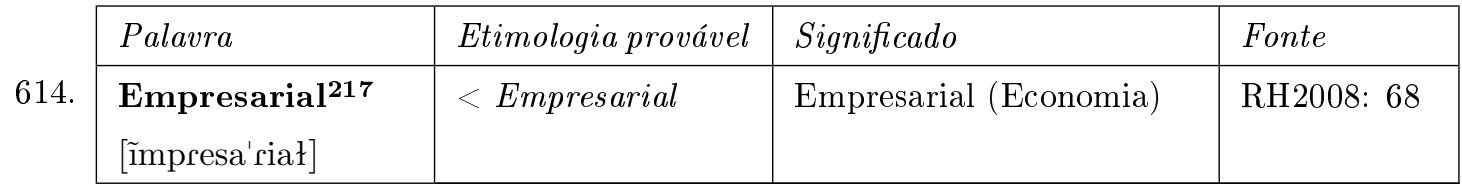

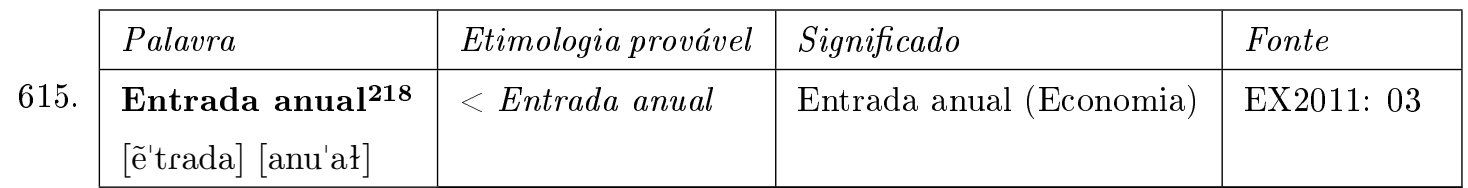

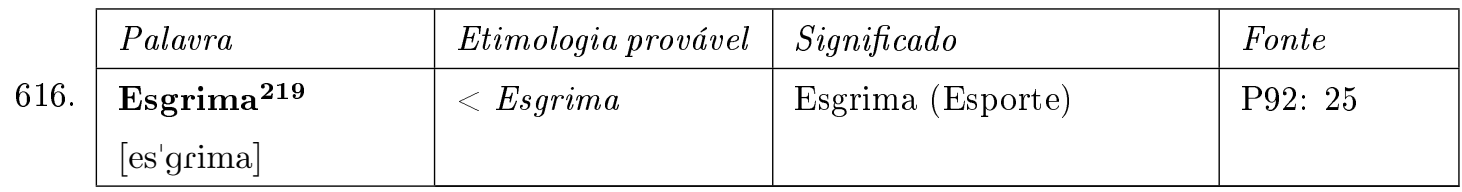

\begin{tabular}{|c|c|c|c|c|}
\hline & Palavra & Etimologia provável & Significado & Fonte \\
\hline 617. & $\begin{array}{l}\text { Esgrimista } \\
\text { [esgri'mista] }\end{array}$ & $<$ Esgrimista & Esgrimista (Esporte) & P92: 25 \\
\hline
\end{tabular}

\begin{tabular}{|l|l|l|l|l|}
\hline Palavra & Etimologia provável & Significado & Fonte \\
\cline { 2 - 4 } & $\begin{array}{l}\text { Eskalá } \\
\text { [eska'la] }]\end{array}$ & $<$ Escalar & Escalar (Esporte) & RH2008: 71 \\
\hline
\end{tabular}

\begin{tabular}{|c|c|c|c|c|}
\hline & Palavra & Etimologia provável & Significado & Fonte \\
\hline 619. & $\begin{array}{l}\text { Eskalamentu } \\
\text { [eskala'mẽtu] }\end{array}$ & $\longleftarrow$ Escalar & Escalada (Esporte) & RH2008: 71 \\
\hline
\end{tabular}

\begin{tabular}{|c|c|c|c|c|}
\hline \multirow[b]{2}{*}{620.} & Palavra & Etimologia provável & Significado & Fonte \\
\hline & $\begin{array}{l}\text { Farmakologia } \\
\text { [fahmakolo'hia] }\end{array}$ & $<$ Farmacologia & $\begin{array}{l}\text { Farmacologia (Tecnologia } \\
\text { e Desenvolvimento) }\end{array}$ & RH2008: 76 \\
\hline
\end{tabular}

\begin{tabular}{|c|c|c|c|c|}
\hline \multirow[b]{2}{*}{621.} & Palavra & Etimologia provável & Significado & Fonte \\
\hline & $\begin{array}{l}\text { Farmakológiko } \\
\text { [fahmakolo'hiko] }\end{array}$ & $<$ Farmacológico & $\begin{array}{l}\text { Farmacoló-gico (Tecnolo- } \\
\text { gia e Desenvolvimento) }\end{array}$ & RH2008: 76 \\
\hline
\end{tabular}

\begin{tabular}{|l|l|l|l|l|}
\hline 622. & Palavra & Etimologia provável & Significado & Fonte \\
\cline { 2 - 5 } & $\begin{array}{l}\text { Farmakólogo } \\
\text { [fahma'kologo }]\end{array}$ & $<$ Farmacológo & $\begin{array}{l}\text { Farmacoló-go (Tecnologia } \\
\text { e Desenvolvimento) }\end{array}$ & RH2008: 76 \\
\hline
\end{tabular}

\begin{tabular}{|c|c|c|c|c|}
\hline & Palavra & Etimologia provável & Significado & Fonte \\
\hline 623. & $\begin{array}{l}\text { Farmakópola } \\
\text { [fahmako'pola] }\end{array}$ & $<$ Farmacopola & $\begin{array}{l}\text { Farmacêutico (Tecnologia } \\
\text { e Desenvolvimento) }\end{array}$ & RH2008: 76 \\
\hline
\end{tabular}

\footnotetext{
${ }^{217}$ Varia com entreprenùrial ${ }_{284}$.

218 Varia com entrada di benta $a_{90}$.

219 Varia com wega di floret ${ }_{907}$.

220 Varia com farmaséutiko $_{175}$ e botikario 582.
} 


\begin{tabular}{|c|c|c|c|c|}
\hline \multirow[b]{2}{*}{624} & Palavra & Etimologia provável & Significado & Fonte \\
\hline & $\begin{array}{l}\text { Farmaséutiko }^{221} \\
\text { [fahmasu'etiko] }\end{array}$ & $\begin{array}{l}<\quad \text { Farmacêu-tico } \\
\text { PT / Farmacéutico } \\
\text { ESP }\end{array}$ & $\begin{array}{l}\text { Farmacêutico (Tecnologia } \\
\text { e Desenvolvimento) }\end{array}$ & RH2008: 76 \\
\hline \multirow[b]{2}{*}{625.} & Palavra & Etimologia provável & Significado & Fonte \\
\hline & $\begin{array}{l}\text { Farmasia }^{222} \\
\text { [fah'masia] }\end{array}$ & $\begin{array}{l}<\text { Farmácia PT / } \\
\text { Farmacia ESP }\end{array}$ & $\begin{array}{l}\text { Farmácia (Tecnologia e } \\
\text { Desenvolvimento) }\end{array}$ & RH2008: 76 \\
\hline \multirow[b]{2}{*}{626.} & Palavra & Etimologia provável & Significado & Fonte \\
\hline & $\begin{array}{l}\text { Fidusiario } \\
\text { [fidusi'ario] }\end{array}$ & $\begin{array}{l}<\text { Fiduciário } \mathrm{PT} / \\
\text { Fiduciario ESP }\end{array}$ & Fiduciário (Economia) & HH88: 79 \\
\hline \multirow[b]{2}{*}{627.} & Palavra & Etimologia provável & Significado & Fonte \\
\hline & $\begin{array}{l}\text { Finansa }^{223} \\
\text { [fi'nãsa] }\end{array}$ & $\begin{array}{l}<\text { Finanças } \mathrm{PT} / \\
\text { Finanzas } \mathrm{ESP}\end{array}$ & $\begin{array}{l}\text { Finanças, fundos (Econo- } \\
\text { mia) }\end{array}$ & RH2008: 79 \\
\hline
\end{tabular}

\begin{tabular}{|l|l|l|l|}
\hline Palavra & Etimologia provável & Significado & Fonte \\
\cline { 2 - 4 } & $\begin{array}{l}\text { Finansia } 224 \\
\text { [finãsi'a] }\end{array}$ & $\begin{array}{l}\text { Finanças, fundos (Econo- } \\
\text { mia) }\end{array}$ & RH2008: 79 \\
& & & \\
\hline
\end{tabular}

\begin{tabular}{|c|c|c|c|}
\hline Palavra & Etimologia provável & Significado & Fonte \\
\hline \begin{tabular}{l|l}
629. & Finansiá \\
& {$[$ finãsi'a] }
\end{tabular} & $<$ Financiar & Financiar (Economia) & RH2008: 79 \\
\hline
\end{tabular}

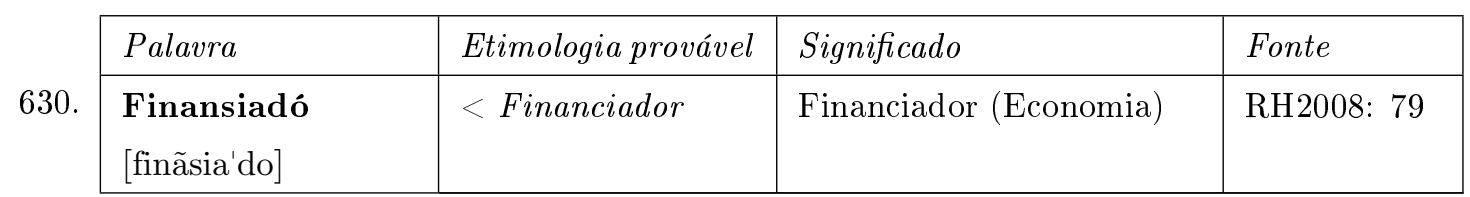

\begin{tabular}{|l|l|l|l|}
\hline Palavra & Etimologia provável & Significado & Fonte \\
\hline Finansiamentu & $<$ Financiamento & Financia-mento (Econo- & RH2008: 79 \\
[finãsia'mẽtu] & $\mathrm{PT} \mathrm{/} \mathrm{Financiami-}$ & mia) \\
& ento ESP & & \\
\hline
\end{tabular}

\begin{tabular}{|l|l|l|l|}
\hline 632. & Etimologia provável & Significado & Fonte \\
\hline $\begin{array}{l}\text { Finansiero } \\
\text { [finãsi'ero] }\end{array}$ & $<$ Financiero & Financeiro (Economia) & RH2008: 79 \\
\hline
\end{tabular}

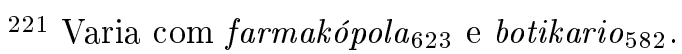

222 Varia com botika $a_{581}$.

${ }^{223}$ Varia com finansia ${ }_{628}$.

224 Varia com finansa $_{627}$. 


\begin{tabular}{|l|l|l|l|l|}
\hline 633. & Palavra & Etimologia provável & Significado & Fonte \\
\cline { 2 - 4 } & $\begin{array}{l}\text { Firma } \\
{[\text { 'fihma }]}\end{array}$ & Firma (Economia) & RH2008: 134 \\
\hline
\end{tabular}

634.

\begin{tabular}{|l|l|l|l|}
\hline Palavra & Etimologia provável & Significado & Fonte \\
\hline $\begin{array}{l}\text { Fiskal } \\
{[\text { fis'kał }]}\end{array}$ & $<$ Fiscal & Fiscal (Economia) & S85: 03 \\
\hline
\end{tabular}

635.

\begin{tabular}{|l|l|l|l|}
\hline Palavra & Etimologia provável & Significado & Fonte \\
\hline $\begin{array}{l}\text { Forsa di kompra } \\
\text { ['fohsa] [di] ['kõpra] }\end{array}$ & $<$ Força de compra & $\begin{array}{l}\text { Força de compra (Econo- } \\
\text { mia) }\end{array}$ & S85: 35 \\
& & \\
\hline
\end{tabular}

636.

\begin{tabular}{|l|l|l|l|}
\hline Palavra & Etimologia provável & Significado & Fonte \\
\hline $\begin{array}{l}\text { Fotokopiá } \\
\text { fotokopi'a }]\end{array}$ & $<$ Fotocopiar & $\begin{array}{l}\text { Fotocopiar (Tecnologia e } \\
\text { Desenvolvimento) }\end{array}$ & RH2008: 77 \\
\hline
\end{tabular}

637.

\begin{tabular}{|l|l|l|l|}
\hline Palavra & Etimologia provável & Significado & Fonte \\
\hline $\begin{array}{l}\text { Futbòl } \\
\text { fut'boł }]\end{array}$ & $\begin{array}{l}<\text { Futebol PT / } \\
\text { Fútbol ESP }\end{array}$ & Futebol (Esporte) & RH2008: 85 \\
\hline
\end{tabular}
638.

\begin{tabular}{|l|l|l|l|}
\hline Palavra & Etimologia provável & Significado & Fonte \\
\hline $\begin{array}{l}\text { Futbolístiko 225 } \\
\text { futbo'listiko }]\end{array}$ & $<$ Futebolístico PT & Jogador de futebol (Es- & H44: 13 \\
& $/$ Futbolistico ESP & porte) & \\
\hline
\end{tabular}

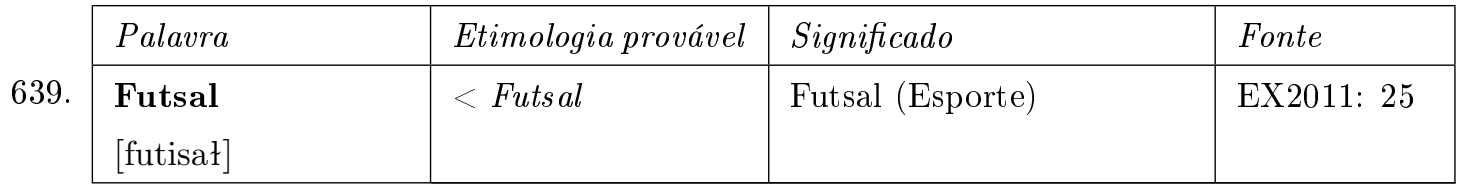

\begin{tabular}{|c|c|c|c|}
\hline Palavra & Etimologia provável & Significado & Fonte \\
\hline $\begin{array}{l}\text { Gabinete } \\
\text { [gabi'nete] }\end{array}$ & $<$ Gabinete & Gabinete (Política) & EX2011:03 \\
\hline
\end{tabular}

\begin{tabular}{|c|c|c|c|}
\hline Palavra & Etimologia provável & Significado & Fonte \\
\hline $\begin{array}{l}\text { Gai di skopèt } \\
\text { ['gaj] [di] [isko'pet] }\end{array}$ & $\begin{array}{l}<\text { Gatilho de esco- } \\
\text { peta }\end{array}$ & $\begin{array}{l}\text { Disparo de arma (Tecnolo- } \\
\text { gia e Desenvolvimento) }\end{array}$ & RH2008: 86 \\
\hline
\end{tabular}

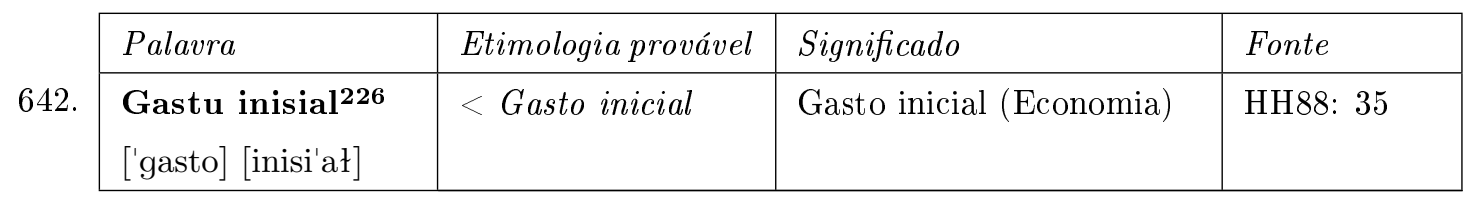

225 Varia com futbolista ${ }_{101}$.

${ }^{226}$ Varia com aanloopkosten ${ }_{254}$. 


\begin{tabular}{|c|c|c|c|c|}
\hline \multirow[b]{2}{*}{643.} & Palavra & Etimologia provável & Significado & Fonte \\
\hline & $\begin{array}{l}\text { Gerensia } \\
{[\text { he'rẽsia }]}\end{array}$ & $\begin{array}{l}<\text { Gerência PT } \\
\text { Gerencia ESP }\end{array}$ & Gerência (Política) & EX2011:07 \\
\hline \multirow[b]{2}{*}{644.} & Palavra & Etimologia provável & Significado & Fonte \\
\hline & $\begin{array}{l}\text { Gobernador } \\
\text { [gobehna'do] }\end{array}$ & $<$ Governador & Governador (Política) & $\begin{array}{l}\text { RH2008: } \\
143\end{array}$ \\
\hline \multirow[b]{2}{*}{645.} & Palavra & Etimologia provável & Significado & Fonte \\
\hline & $\begin{array}{l}\text { Gobernamental } \\
\text { [gobehnamẽ'tał] }\end{array}$ & $<$ Governamental & Governamen-tal (Política) & $\begin{array}{l}\text { RH2008: } \\
153\end{array}$ \\
\hline \multirow[b]{2}{*}{646.} & Palavra & Etimologia provável & Significado & Fonte \\
\hline & $\begin{array}{l}\text { Gol } \\
{[\text { 'goł }]}\end{array}$ & $<G o l$ & Gol (Esporte) & RH2008: 90 \\
\hline \multirow[b]{2}{*}{647.} & Palavra & Etimologia provável & Significado & Fonte \\
\hline & $\begin{array}{l}\text { Hidróliko } \\
\text { [hi'droliko] }\end{array}$ & $\begin{array}{l}<\text { Hidráulico } \mathrm{PT} / \\
\text { Hidraulico } \mathrm{ESP}\end{array}$ & $\begin{array}{l}\text { Hidráu-lico (Tencologia e } \\
\text { Desenvolvimento) }\end{array}$ & RH2008: 98 \\
\hline \multirow[b]{2}{*}{648.} & Palavra & Etimologia provável & Significado & Fonte \\
\hline & $\begin{array}{l}\text { Hipismo } \\
{[\text { xi'pismu] }}\end{array}$ & $<$ Hipismo & Hipismo (Esporte) & RH2008: 98 \\
\hline \multirow[b]{2}{*}{649.} & Palavra & Etimologia provável & Significado & Fonte \\
\hline & $\begin{array}{l}\text { Hipotek } \\
{[\text { ipo'tejk] }}\end{array}$ & $\begin{array}{l}<\text { Hipóteca PT / } \\
\text { Hipoteca ESP }\end{array}$ & Hipóteca (Economia) & HH88: 26 \\
\hline \multirow[b]{2}{*}{650.} & Palavra & Etimologia provável & Significado & Fonte \\
\hline & $\begin{array}{l}\text { Hipotekario } \\
\text { [ipote'kario] }\end{array}$ & $\begin{array}{l}<\text { Hipotecário } \mathrm{PT} / \\
\text { Hipotecario } \mathrm{ESP}\end{array}$ & Hipotecário (Economia) & HH88: 26 \\
\hline \multirow[b]{2}{*}{651.} & Palavra & Etimologia provável & Significado & Fonte \\
\hline & $\begin{array}{l}\text { Hortikultura } \\
\text { [hohtikuł'tura] }\end{array}$ & $<$ Horticultura & Horticultura (Economia) & S85: 37 \\
\hline \multirow[b]{2}{*}{652.} & Palavra & Etimologia provável & Significado & Fonte \\
\hline & $\begin{array}{l}\text { Impresa } \\
{[\tilde{1} \text { presa }]}\end{array}$ & $<$ Empresa & Empresa (Economia) & RH2008: 105 \\
\hline \multirow[b]{2}{*}{653.} & Palavra & Etimologia provável & Significado & Fonte \\
\hline & $\begin{array}{l}\text { Impresario } \\
\text { [̃̃mpre'sario] }\end{array}$ & $\begin{array}{l}<\text { Empresário } \mathrm{PT} / \\
\text { Empresario ESP }\end{array}$ & Empresário (Economia) & RH2008: 105 \\
\hline
\end{tabular}




\begin{tabular}{|l|l|l|l|}
\hline Palavra & Etimologia provável & Significado & Fonte \\
\hline Impulsado & $<$ Impulsado & Impulsado - termo técnico, & D86: 168 \\
utilizado no beisebol (Es- & \\
[ĩpułsa'do] & & porte) & \\
& & & \\
\hline
\end{tabular}

\begin{tabular}{|c|c|c|c|c|}
\hline & Palavra & Etimologia provável & Significado & Fonte \\
\hline 655. & $\begin{array}{l}\text { Industria } \\
\text { [î́dustria] }\end{array}$ & $\begin{array}{l}<\text { Indústria } \mathrm{PT} / \\
\text { Industria } \mathrm{ESP}\end{array}$ & Indústria (Economia) & RH2008: 107 \\
\hline
\end{tabular}

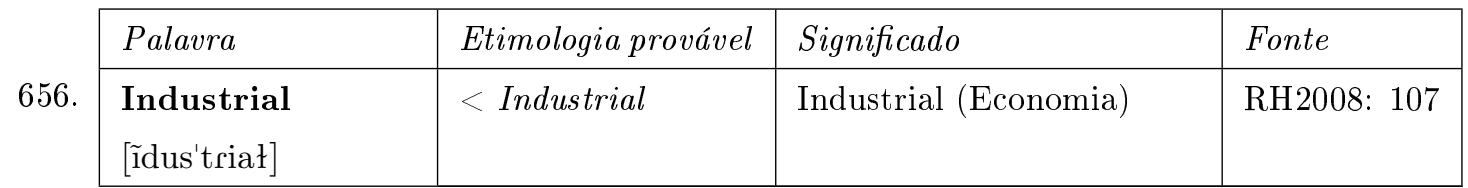

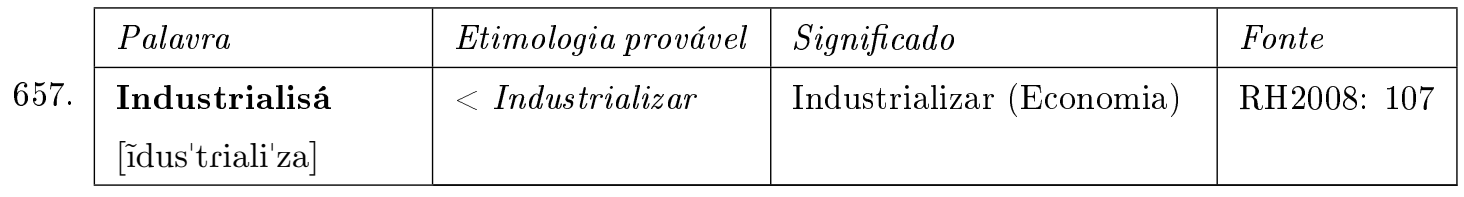

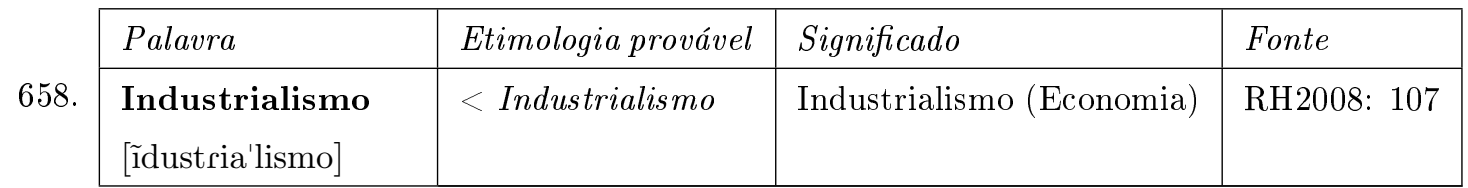

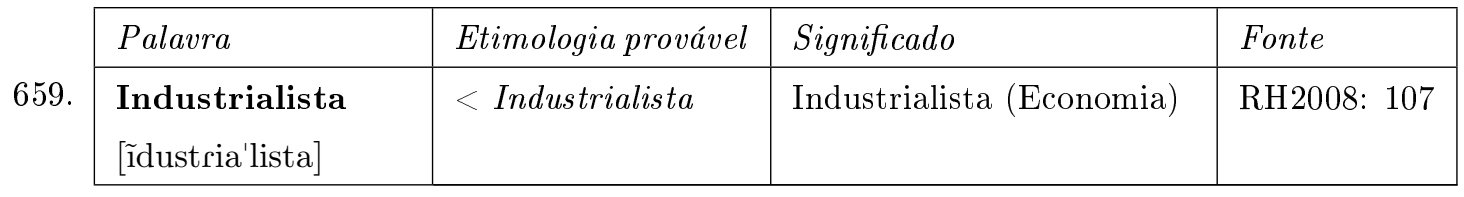

660.

\begin{tabular}{|l|l|l|l|}
\hline Palavra & Etimologia provável & Significado & Fonte \\
\hline $\begin{array}{l}\text { Industrialmente } \\
\text { [̃dustrial'mẽte] }\end{array}$ & $<$ Industrialmente & Industrialmente (Econo- & RH2008: 107 \\
& mia) & & \\
\hline
\end{tabular}

661.

\begin{tabular}{|l|l|l|l|}
\hline Palavra & Etimologia provável & Significado & Fonte \\
\hline Inflashonario & $<$ Inflacionário & Inflacionário (Economia) & RH2008: 108 \\
[̃flafõ'nario] & $\mathrm{PT} \mathrm{/} \mathrm{Inflacionario}$ & & \\
& $\mathrm{ESP}$ & & \\
\hline
\end{tabular}

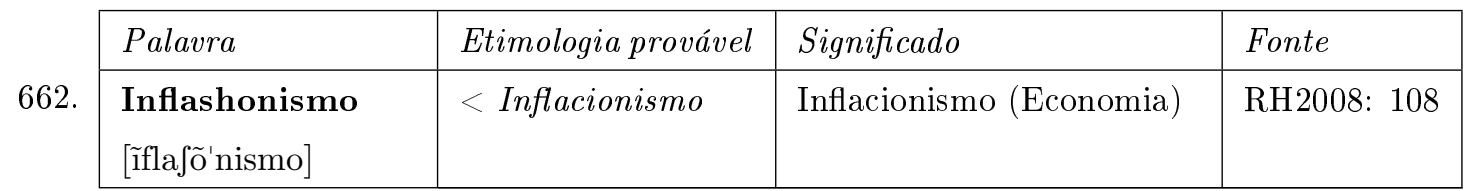

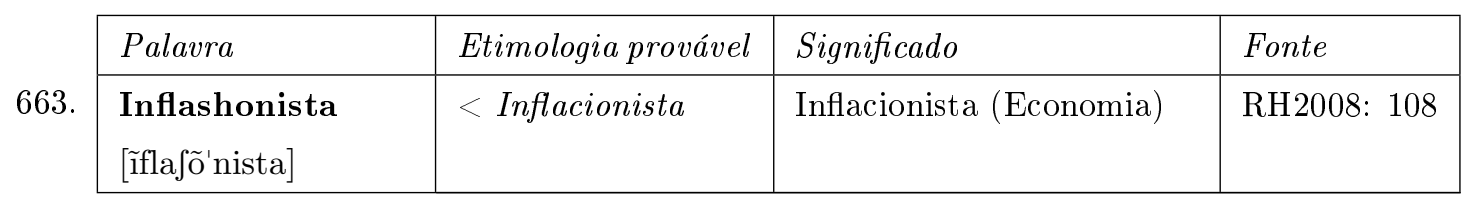




\begin{tabular}{|l|l|l|l|}
\hline 6alavra & Etimologia provável & Significado & Fonte \\
\cline { 2 - 5 } & $\begin{array}{l}\text { Informe } \\
\text { [i'fohme }]\end{array}$ & $\begin{array}{l}\text { Notícias (Tecnologia e De- } \\
\text { senvolvimento) }\end{array}$ & RH2008: 108 \\
\hline
\end{tabular}

\begin{tabular}{|l|l|l|l|}
\hline Palavra & Etimologia provável & Significado & Fonte \\
\hline Interferensha & $<$ Interferência PT & Quando um jogador im- & D86: 169 \\
[ĩtehfe'rẽfa] & $/$ Interferencia ESP & $\begin{array}{l}\text { pede o outro de fazer algo } \\
\text { (beisebol) (Esporte) }\end{array}$ & \\
& & & \\
\hline
\end{tabular}

\begin{tabular}{|c|c|c|c|}
\hline Palavra & Etimologia provável & Significado & Fonte \\
\hline \begin{tabular}{l|l}
666. & Kalkulo \\
{$[$ 'kałkulo] }
\end{tabular} & < Cálculo & Cálculo (Economia) & EX2011: 11 \\
\hline
\end{tabular}

\begin{tabular}{|l|l|l|l|}
\hline Palavra & Etimologia provável & Significado & Fonte \\
\cline { 2 - 4 } & Kambio & $<$ Câmbio PT / & Câmbio (Economia) \\
['kãbjo] & Cambio ESP & & S85: 03 \\
\hline
\end{tabular}

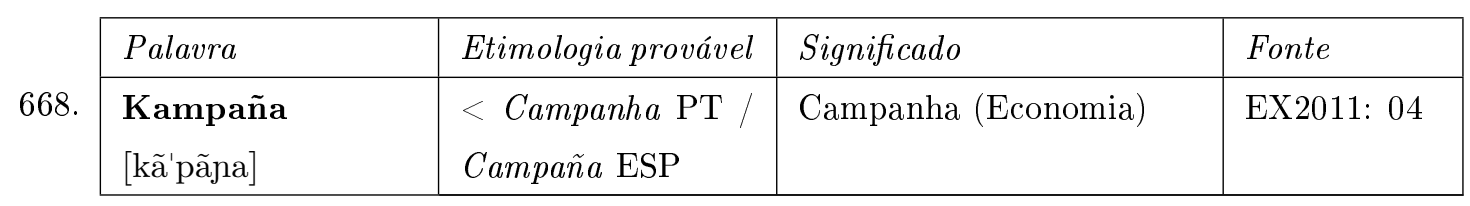

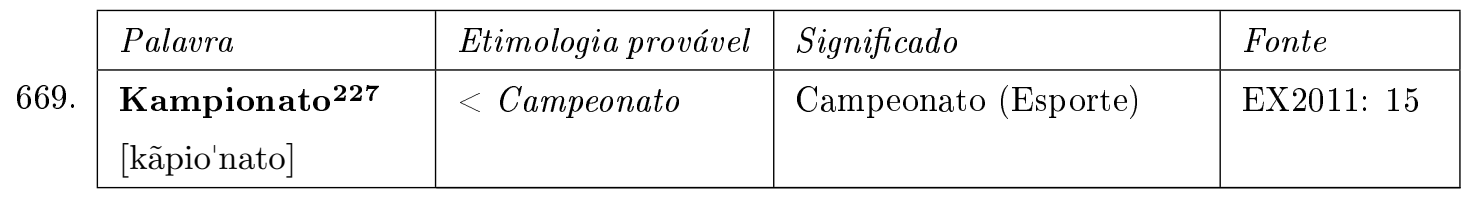

\begin{tabular}{|l|l|l|l|}
\hline 6alavra & Etimologia provável & Significado & Fonte \\
\cline { 2 - 5 } & $\begin{array}{l}\text { Kandidato } \\
\text { [kãdi'dato }]\end{array}$ & Candidato (Política) & EX2011:11 \\
\hline
\end{tabular}

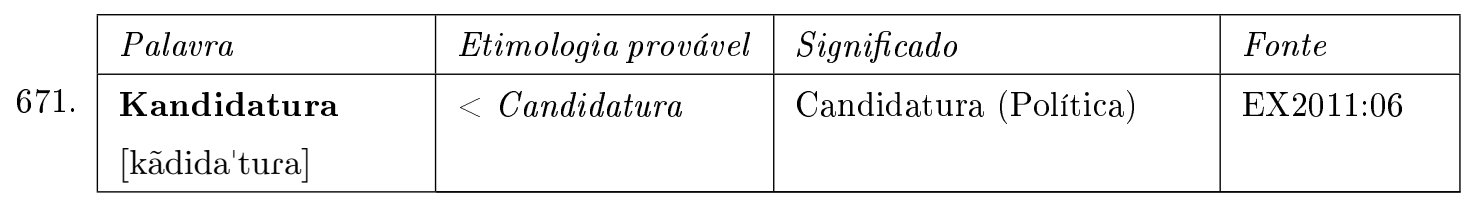

\begin{tabular}{|l|l|l|l|}
\hline 6alavra & Etimologia provável & Significado & Fonte \\
\cline { 2 - 5 } & $\begin{array}{l}\text { Kanoa } \\
{[\text { 'kãnoa }]}\end{array}$ & Canoa (Esporte) & P92: 25 \\
\hline
\end{tabular}

\footnotetext{
227 Varia com championship ${ }_{642}$.
} 
673

\begin{tabular}{|l|l|l|l|}
\hline Palavra & Etimologia provável & Significado & Fonte \\
\hline $\begin{array}{l}\text { Kapital líkido } 228 \\
\text { [kapi'tał] ['likido] }\end{array}$ & $<$ Capital líquido & $\begin{array}{l}\text { Capital líquido (Econo- } \\
\text { mia) }\end{array}$ & HH88: 40 \\
& & & \\
\hline
\end{tabular}

674

\begin{tabular}{|l|l|l|l|}
\hline Palavra & Etimologia provável & Significado & Fonte \\
\hline $\begin{array}{l}\text { Kapital pagá229 } \\
\text { [kapi'tał] [pa'ga] }\end{array}$ & $<$ Capital / Pagar & $\begin{array}{l}\text { Capital social integrali- } \\
\text { zado (Economia) }\end{array}$ & HH88: 40 \\
& & & \\
\hline
\end{tabular}

\begin{tabular}{|l|l|l|l|}
\hline Palavra & Etimologia provável & Significado & Fonte \\
\hline $\begin{array}{l}\text { Kapital sirku- } \\
\text { lante } \\
\text { 230 } \\
\text { [kapi'tał }] \\
\text { [sihku'lãte }]\end{array}$ & $\begin{array}{l}\text { Capital circu- } \\
\text { lante }\end{array}$ & $\begin{array}{l}\text { Capital ativo, circulante } \\
\text { (Economia) }\end{array}$ & HH88: 40 \\
\hline
\end{tabular}

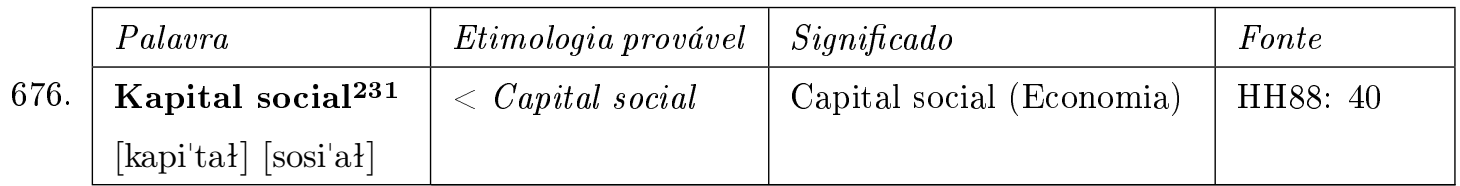

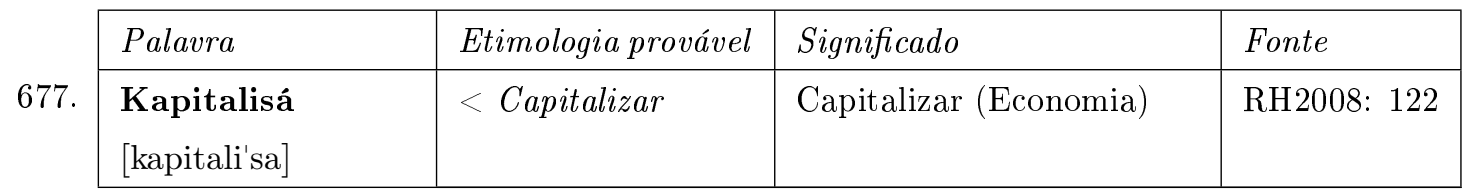

\begin{tabular}{|l|l|l|l|l|}
\hline 678. & Palavra & Etimologia provável & Significado & Fonte \\
\cline { 2 - 4 } & $\begin{array}{l}\text { Kapitalismo } \\
\text { [kapita'lismo }]\end{array}$ & $<$ Capitalismo & Capitalismo (Economia) & RH2008: 122 \\
\hline
\end{tabular}

\begin{tabular}{|l|l|l|l|l|}
\hline 679. & Palavra & Etimologia provável & Significado & Fonte \\
\cline { 2 - 4 } & $\begin{array}{l}\text { Kapitalista } \\
\text { [kapita'lista }]\end{array}$ & $<$ Capitalista & Capitalista (Economia) & RH2008: 122 \\
\hline
\end{tabular}

\begin{tabular}{|l|l|l|l|}
\hline Palavra & Etimologia provável & Significado & Fonte \\
\hline Kapitalístika- & $<$ Capitalisti- & Capitalistica-mente (Eco- & RH2008: 122 \\
mente & camente PT / & nomia) & \\
[kapitalistika'mẽte] $]$ & Capitalisticamiente & & \\
& ESP & & \\
\hline
\end{tabular}

${ }^{228}$ Varia com liquide middelen $n_{317}$.

229 Varia com gestort kapitaal ${ }_{292}$.

230 Varia com vlottende activa $a_{401}$.

231 Varia com maatschappelijk kapitaal ${ }_{320}$. 


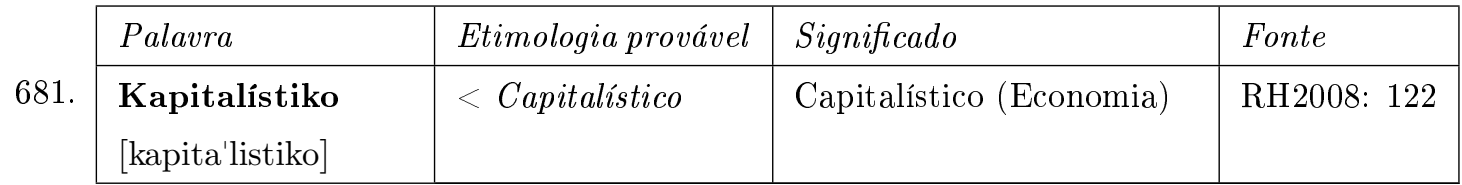

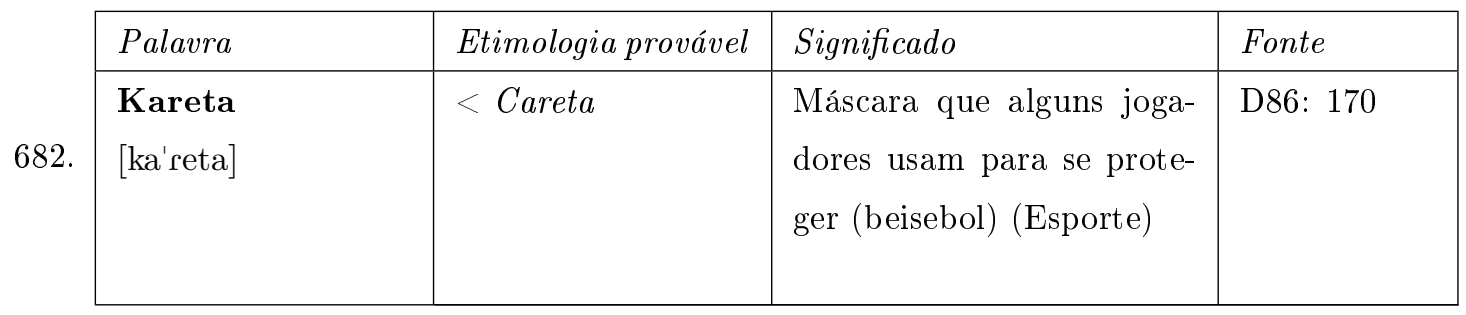

\begin{tabular}{|l|l|l|l|}
\hline 683. & Etimologia provável & Significado & Fonte \\
\cline { 2 - 4 } & $\begin{array}{l}\text { Kartel } \\
{[\text { kah'tct }]}\end{array}$ & Cartel (Economia) & RH2008: 123 \\
\hline
\end{tabular}

\begin{tabular}{|l|l|l|l|}
\hline 6alavra & Etimologia provável & Significado & Fonte \\
\cline { 2 - 4 } & $\begin{array}{l}\text { Kímika } \\
\text { ['kimika] }\end{array}$ & $\begin{array}{l}\text { Química (Tecnologia e De- } \\
\text { senvolvimento) }\end{array}$ & RH2008: 127 \\
\hline
\end{tabular}

\begin{tabular}{|l|l|l|l|}
\hline 2685. & Etimologia provável & Significado & Fonte \\
\cline { 2 - 4 } & $\begin{array}{l}\text { Kímiko } \\
{[\text { 'kimiko] }}\end{array}$ & $\begin{array}{l}\text { Químico (Tecnologia e De- } \\
\text { senvolvimento) }\end{array}$ & RH2008: 127 \\
\hline
\end{tabular}

\begin{tabular}{|c|c|c|c|}
\hline Palavra & Etimologia provável & Significado & Fonte \\
\hline 686. $\begin{array}{l}\text { Kímiko } \\
{[\text { 'kimiko] }}\end{array}$ & $<$ Químico & $\begin{array}{l}\text { Substância química (Tec- } \\
\text { nologia e Desenvolvi- } \\
\text { mento) }\end{array}$ & RH2008: 127 \\
\hline
\end{tabular}

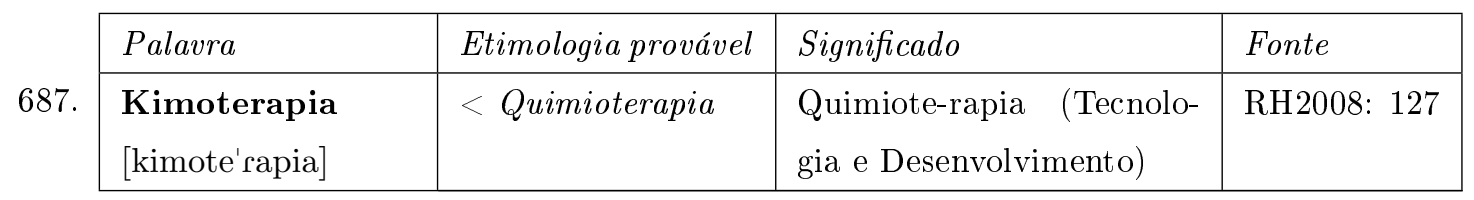

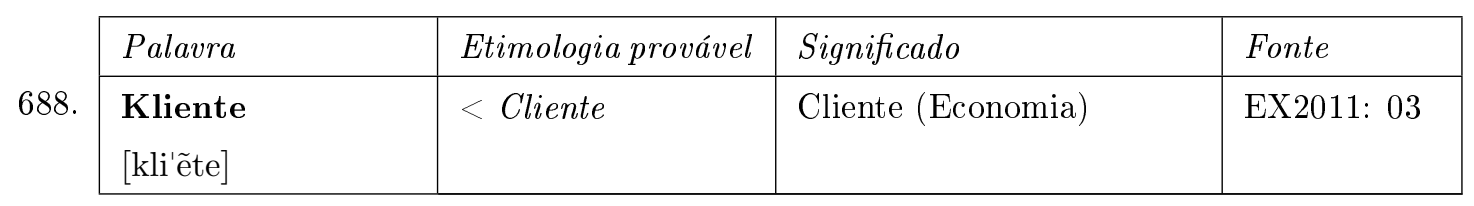

\begin{tabular}{|l|l|l|l|}
\hline Palavra & Etimologia provável & Significado & Fonte \\
\hline $\begin{array}{l}\text { Kokaina } \\
{[\text { koka'ina }]}\end{array}$ & $<$ Cocaína & $\begin{array}{l}\text { Cocaína (Tecnologia e De- } \\
\text { senvolvimento) }\end{array}$ & RH2008: 131 \\
\hline
\end{tabular}

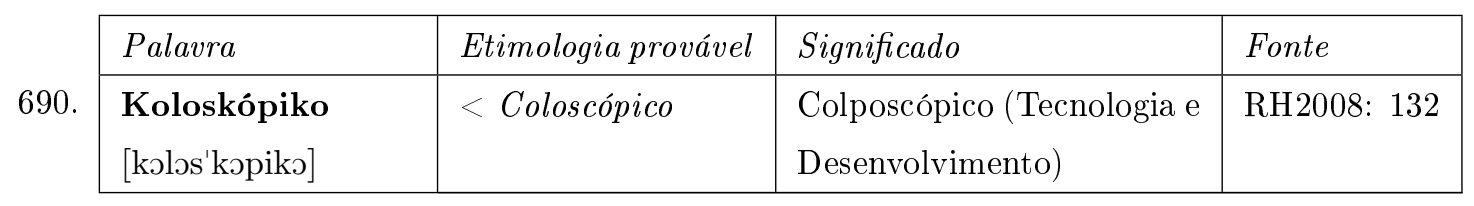




\begin{tabular}{|l|l|l|l|}
\hline 6alavra & Etimologia provável & Significado & Fonte \\
\cline { 2 - 4 } & $\begin{array}{l}\text { Koloskopio } \\
\text { [kolos'kopio] }\end{array}$ & $\begin{array}{l}\text { Colposcópio (Tecnologia e } \\
\text { Desenvolvimento) }\end{array}$ & RH2008: 132 \\
\hline
\end{tabular}

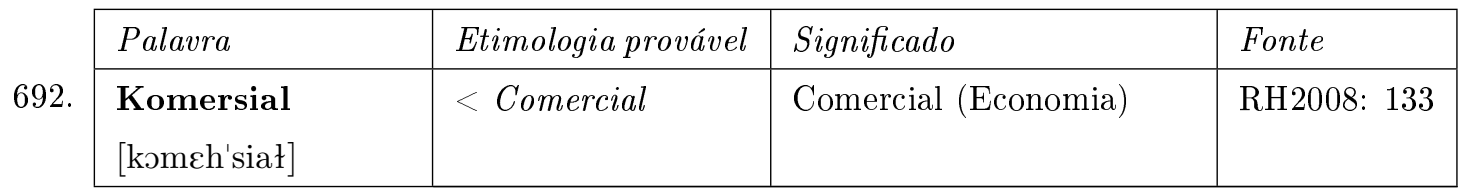

\begin{tabular}{|c|c|c|c|c|}
\hline & Palavra & Etimologia provável & Significado & Fonte \\
\hline 693. & $\begin{array}{l}\text { Komersialisá } \\
\text { [komehsiali'sa] }\end{array}$ & $<$ Comercializar & Comercializar (Economia) & RH2008: 133 \\
\hline
\end{tabular}

694.

\begin{tabular}{|l|l|l|l|}
\hline Palavra & Etimologia provável & Significado & Fonte \\
\hline $\begin{array}{l}\text { Komersialismo } \\
\text { [komehsia'lismo }]\end{array}$ & $<$ Comercialismo & $\begin{array}{l}\text { Comercialis-mo (Econo- } \\
\text { mia) }\end{array}$ & RH2008: 133 \\
& & & \\
\hline
\end{tabular}

695.

\begin{tabular}{|l|l|l|l|}
\hline Palavra & Etimologia provável & Significado & Fonte \\
\hline $\begin{array}{l}\text { Komersiante } \\
\text { [komchsi'ãte] }\end{array}$ & $<$ Comerciante & Comerciante (Economia) & RH2008: 133 \\
\hline
\end{tabular}

696.

\begin{tabular}{|l|l|l|l|}
\hline Palavra & Etimologia provável & Significado & Fonte \\
\hline $\begin{array}{l}\text { Komersio } \\
\text { [ko'mehsio] }\end{array}$ & $\begin{array}{l}<\text { Comércio PT / } \\
\text { Comercio ESP }\end{array}$ & Comércio (Economia) & RH2008: 133 \\
\hline
\end{tabular}

\begin{tabular}{|l|l|l|l|}
\hline 6alavra & Etimologia provável & Significado & Fonte \\
\cline { 2 - 4 } & $<$ Conectar & $\begin{array}{l}\text { Ação em que a bola choca } \\
\text { (beisebol) (Esporte) }\end{array}$ & D86: 170 \\
{$[$ konek'ta] } & $<$ & \\
\hline
\end{tabular}

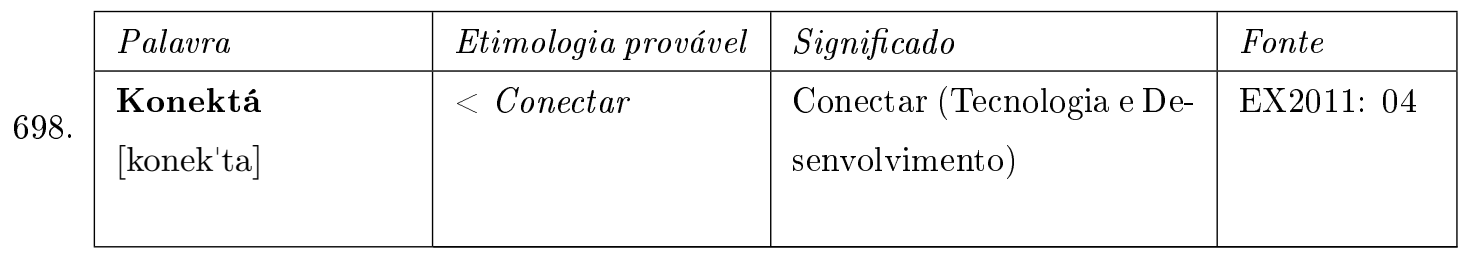

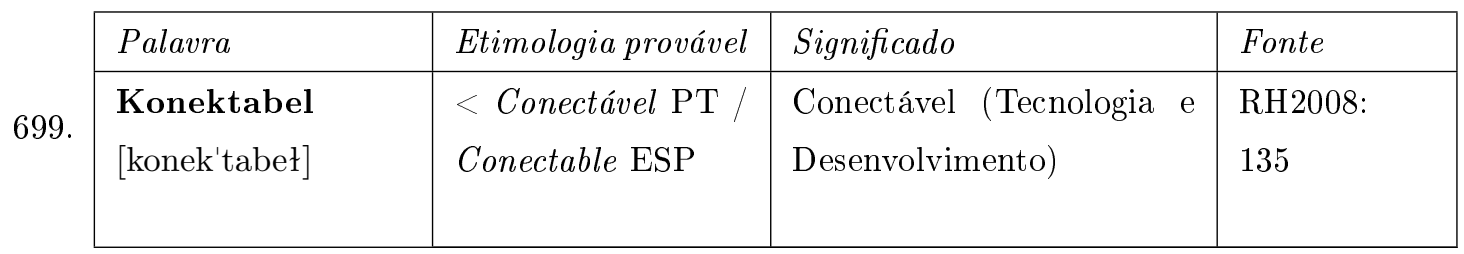

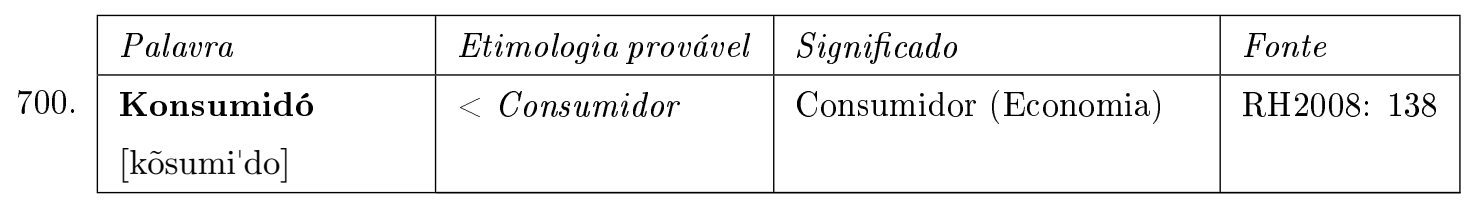




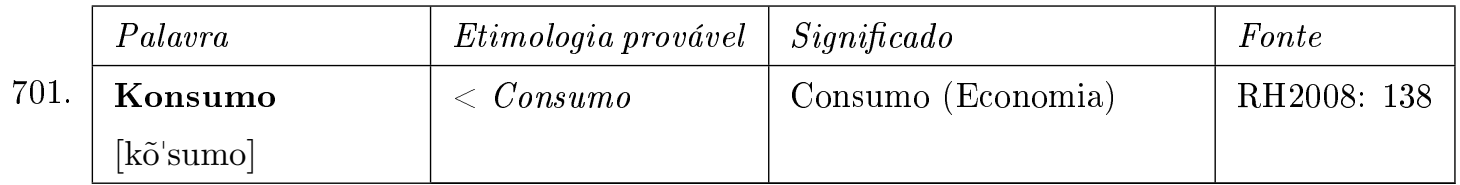

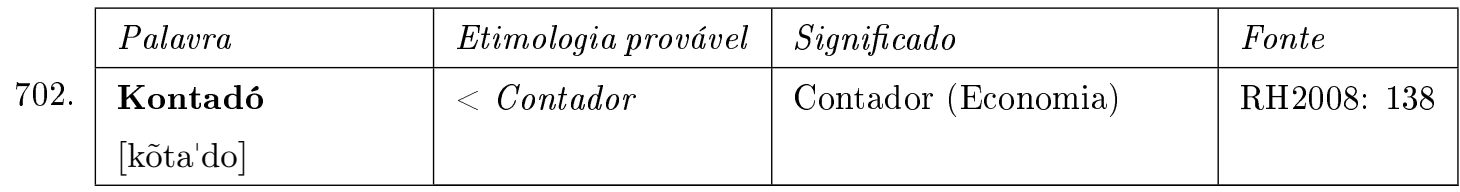

\begin{tabular}{|l|l|l|l|}
\hline Palavra & Etimologia provável & Significado & Fonte \\
\hline Kontrinkante & $<$ Contra-atacante & Contra-atacante (Esporte) & D86: 170 \\
[kõtrĩ'kãte] & $\mathrm{PT} \mathrm{/} \mathrm{Contraata-}$ & & \\
& cante ESP & & \\
\hline
\end{tabular}

704.

\begin{tabular}{|l|l|l|l|}
\hline Palavra & Etimologia provável & Significado & Fonte \\
\hline $\begin{array}{l}\text { Kore } \\
\text { [ko're }]\end{array}$ & $<$ Correr & Correr (Esporte) & RH2008: 139 \\
\hline
\end{tabular}

\begin{tabular}{|l|l|l|l|}
\hline Palavra & Etimologia provável & Significado & Fonte \\
\hline $\begin{array}{l}\text { Koredo } \\
\text { [kore'do] }\end{array}$ & $<$ Corredor & $\begin{array}{l}\text { Quando o batedor se posi- } \\
\text { ciona acima da base (beise- } \\
\text { bol) (Esporte) }\end{array}$ & \\
& & & \\
\hline
\end{tabular}

706.

\begin{tabular}{|l|l|l|l|}
\hline Palavra & Etimologia provável & Significado & Fonte \\
\hline $\begin{array}{l}\text { Koredò } \\
\text { [kore'do }]\end{array}$ & $<$ Corredor & $\begin{array}{l}\text { Corredor, atleta que corre } \\
\text { (Esporte) }\end{array}$ & RH2008: 139 \\
\hline
\end{tabular}

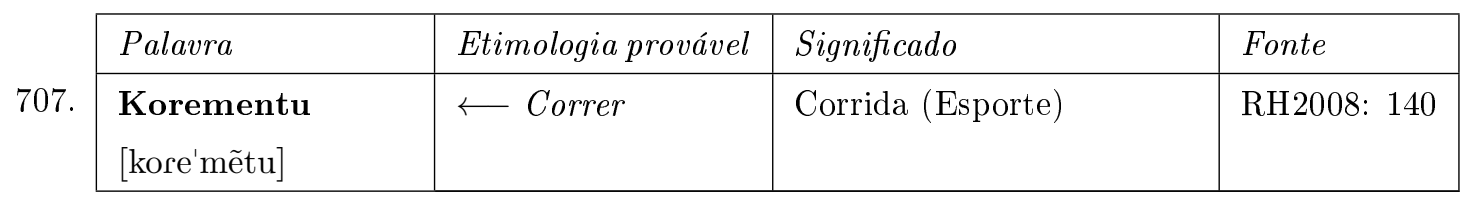

\begin{tabular}{|l|l|l|l|l|}
\hline 708. & Palavra & Etimologia provável & Significado & Fonte \\
\cline { 2 - 4 } & $\begin{array}{l}\text { Kreditá } \\
\text { [kredi'ta }]\end{array}$ & $<$ Creditar & Creditar (Economia) & RH2008: 142 \\
\hline
\end{tabular}

\begin{tabular}{|l|l|l|l|l|}
\hline 709. & Palavra & Etimologia provável & Significado & Fonte \\
\cline { 2 - 4 } & $\begin{array}{l}\text { Krédito } \\
\text { ['kredito] }\end{array}$ & $<$ Crédito & Crédito (Economia) & RH2008: 142 \\
\hline
\end{tabular}

${ }^{232}$ Varia com kuri $_{713}$. 


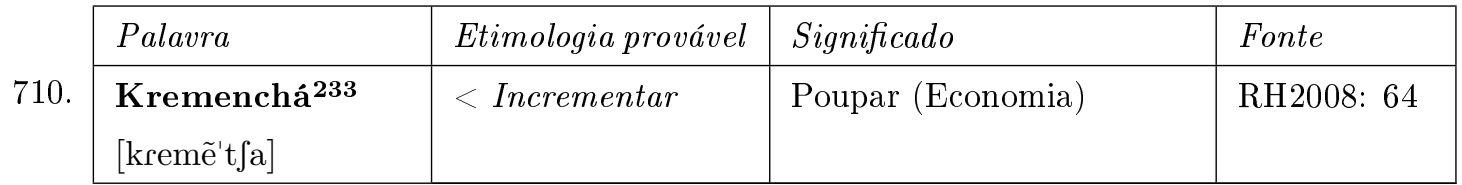

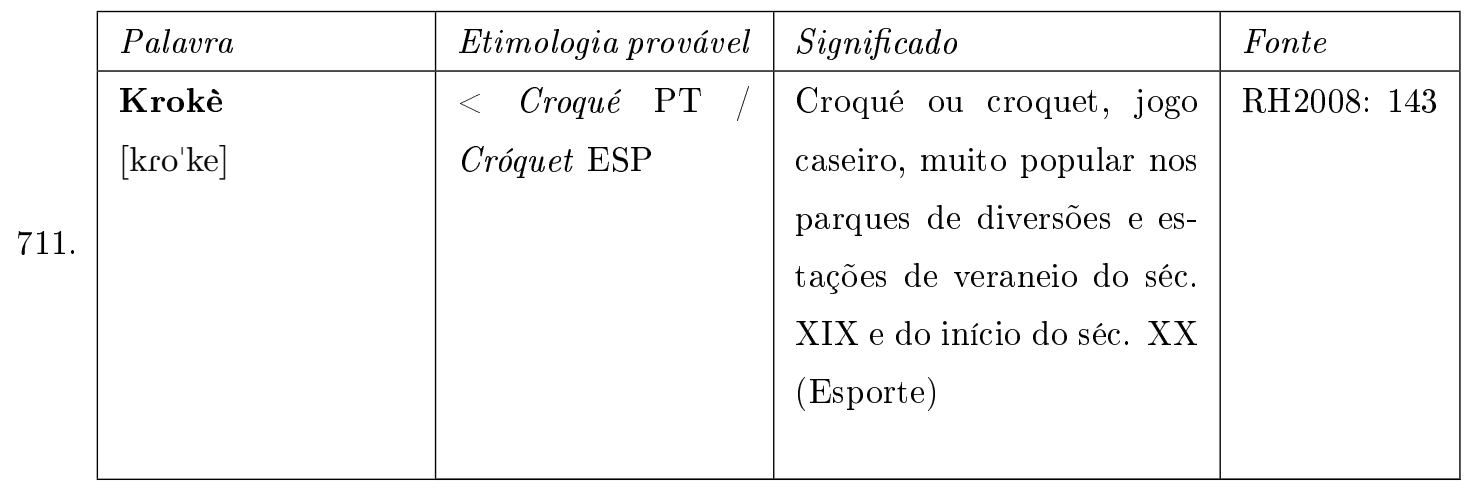

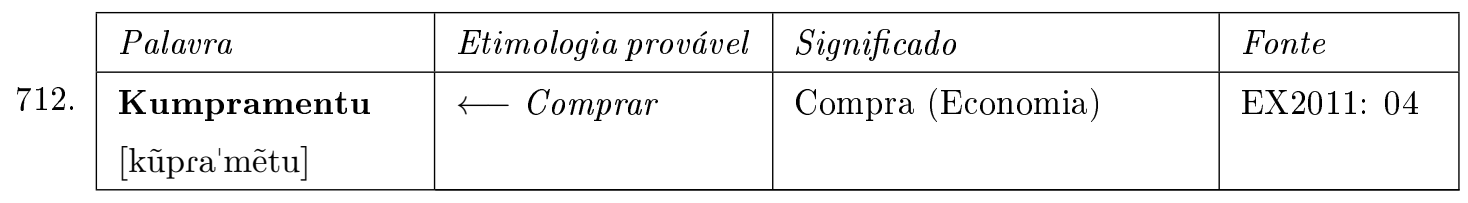

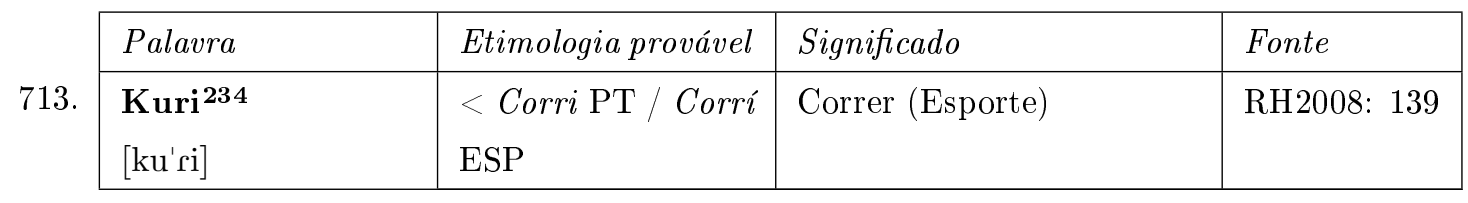

\begin{tabular}{|l|l|l|l|}
\hline Palavra & Etimologia provável & Significado & Fonte \\
\hline Kurva & $<$ Curva & $\begin{array}{l}\text { Movimento da bola (beise- } \\
\text { bol) (Esporte) }\end{array}$ & D86: 171 \\
['kuhfa] & & \\
\hline
\end{tabular}

\begin{tabular}{|l|l|l|l|}
\hline Palavra & Etimologia provável & Significado & Fonte \\
\hline 715. & $\longleftarrow$ Curva & $\begin{array}{l}\text { Lançador que tirar muita } \\
\text { Kurva (beisebol) (Esporte) }\end{array}$ & D86: 171 \\
{$[$ kuh'fero $]$} & & & \\
\hline
\end{tabular}

\begin{tabular}{|l|l|l|l|}
\hline Palavra & Etimologia provável & Significado & Fonte \\
\hline $\begin{array}{l}\text { Labadora } \\
{[\text { laba'dora }]}\end{array}$ & $<$ Lavadora & $\begin{array}{l}\text { Máquina de lavar (Tecno- } \\
\text { logia e Desenvolvimento) }\end{array}$ & RH2008:66 \\
\hline
\end{tabular}

233 Varia com ahorá ${ }_{7}$ e spar $_{375}$.

234 Varia com kore 704 . 


\begin{tabular}{|c|c|c|c|c|}
\hline & Palavra & Etimologia provável & Significado & Fonte \\
\hline 717. & $\begin{array}{l}\text { Lacrosse } \\
\text { [la'krose] }\end{array}$ & $<$ Lacrosse & $\begin{array}{l}\text { Lacrosse, jogo de origem } \\
\text { indígena norte-americana } \\
\text { (Canadá), semelhante ao } \\
\text { hóquei (Esporte) }\end{array}$ & P92: 48 \\
\hline
\end{tabular}

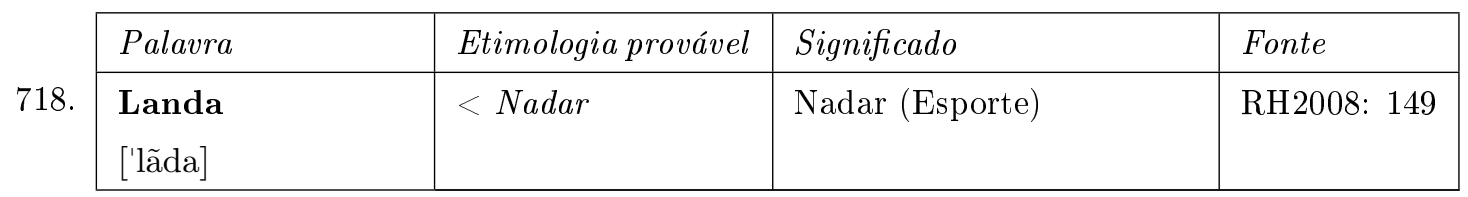

\begin{tabular}{|l|l|l|l|}
\hline 719. & Etimologia provável & Significado & Fonte \\
\cline { 2 - 4 } & $\begin{array}{l}\text { Landadò } \\
{[\text { lãda'do] }}\end{array}$ & Nadador (Esporte) & RH2008: 149 \\
\hline
\end{tabular}

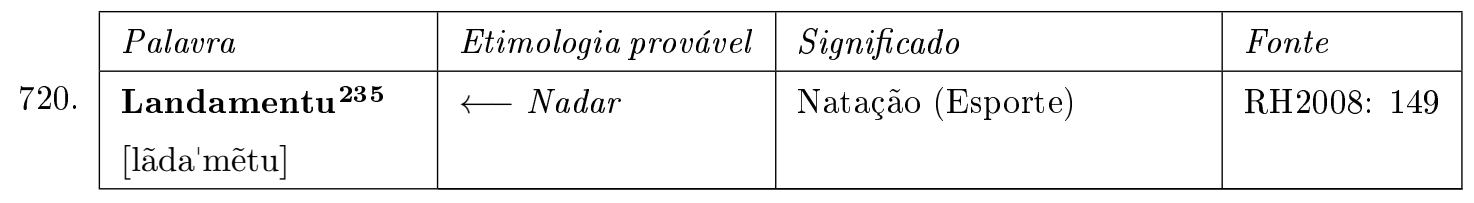

\begin{tabular}{|l|l|l|l|}
\hline Palavra & Etimologia provável & Significado & Fonte \\
\hline Lansamentu & $<$ Lançamento PT & Bola enviada pelo lançador & EX2011: 11 \\
721. & [lãsa'mẽtu $]$ & / Lançamiento ESP & $\begin{array}{l}\text { para o receptor no início de } \\
\text { cada jogada (beisebol) (Es- } \\
\end{array}$ \\
& & porte) & \\
& & & \\
\hline
\end{tabular}

\begin{tabular}{|l|l|l|l|}
\hline Palavra & Etimologia provável & Significado & Fonte \\
\hline Liga & $<$ Liga & Associação formada por & D86: 171 \\
['liga] & & equipes (Esporte) & \\
\hline
\end{tabular}

\begin{tabular}{|l|l|l|l|}
\hline Palavra & Etimologia provável & Significado & Fonte \\
\hline Limosin & $<$ Limusine & Limusine (Tecnologia e De- & RH2008: \\
[limo'si] $]$ & & senvolvimento) & 154 \\
\hline
\end{tabular}

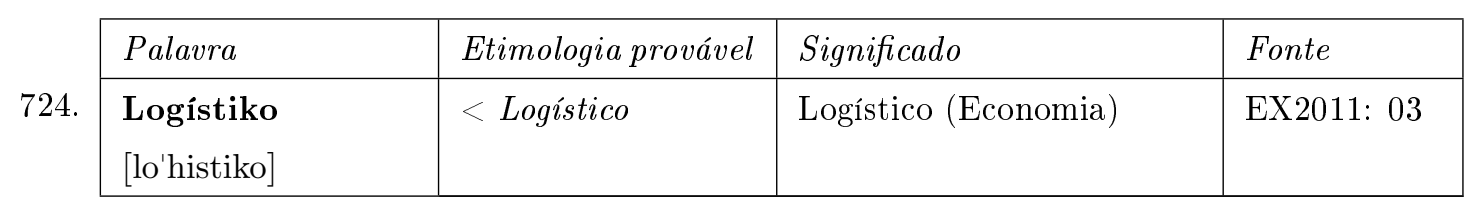

\footnotetext{
235 Varia com natashon ${ }_{174}$.
} 


\begin{tabular}{|l|l|l|l|}
\hline Palavra & Etimologia provável & Significado & Fonte \\
\hline $\begin{array}{l}\text { Lokutor } \\
{[\text { loku'toh }]}\end{array}$ & $<$ Locutor & $\begin{array}{l}\text { Locutor (Tecnologia e De- } \\
\text { senvolvimento) }\end{array}$ & RH2008: \\
& & & 155 \\
\hline
\end{tabular}

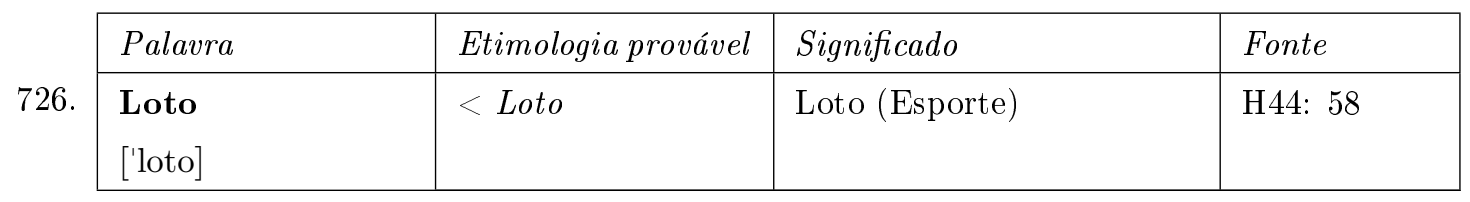

\begin{tabular}{|l|l|l|l|}
\hline Palavra & Etimologia provável & Significado & Fonte \\
\hline Makro ekonó- & $<\quad$ Macro- & Macro-econômico (Econo- & EX2011: 04 \\
miko & econômicor PT & mia) & \\
['makro] & $/$ Macro-económico & & \\
[eko'nomiko] & ESP & & \\
\hline
\end{tabular}

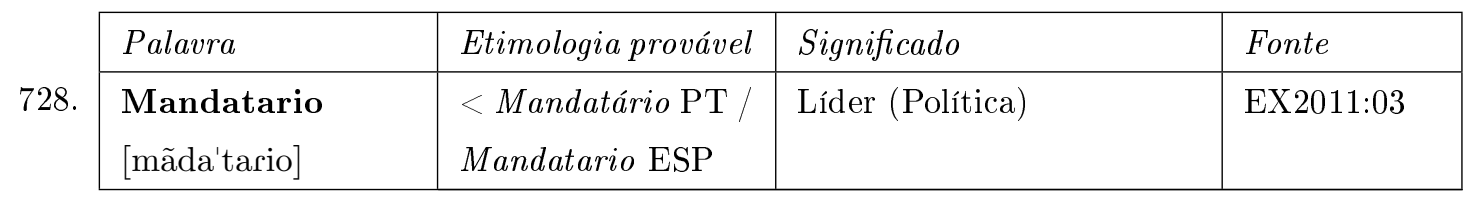

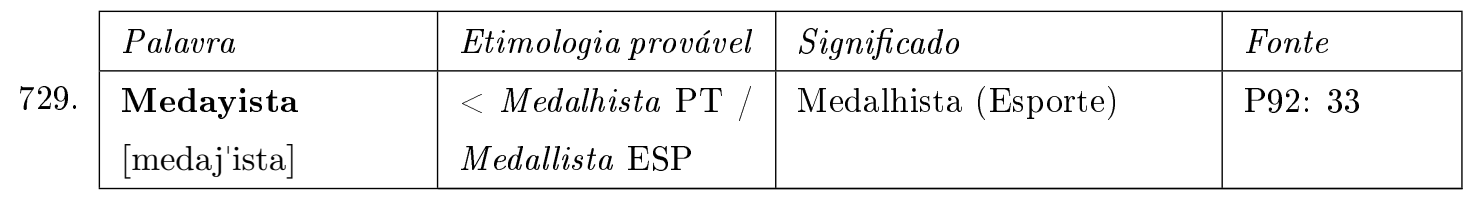

\begin{tabular}{|l|l|l|l|}
\hline Palavra & Etimologia provável & Significado & Fonte \\
\hline Mekánika & $<$ Mecânica PT / & Mecânica (Tecnologia e & RH2008: \\
[me'kanika] & Mecánica ESP & Desenvolvimento) & 165 \\
\hline
\end{tabular}

\begin{tabular}{|c|c|c|c|c|}
\hline & Palavra & Etimologia provável & Significado & Fonte \\
\hline 731 . & $\begin{array}{l}\text { Mekánikamente } \\
\text { [mekanika'mẽte] }\end{array}$ & $\begin{array}{l}<\text { Mecanicamen-te } \\
\mathrm{PT} / \text { Mecánica- } \\
\text { mente ESP }\end{array}$ & $\begin{array}{l}\text { Mecanica-mente (Tecnolo- } \\
\text { gia e Desenvolvimento) }\end{array}$ & $\begin{array}{l}\text { RH2008: } \\
163\end{array}$ \\
\hline
\end{tabular}

\begin{tabular}{|c|c|c|c|c|}
\hline & Palavra & Etimologia provável & Significado & Fonte \\
\hline 732 . & $\begin{array}{l}\text { Mekániko }{ }^{236} \\
{[\text { me'kaniko] }}\end{array}$ & $\begin{array}{l}<\text { Mecânico PT / } \\
\text { Mecánico ESP }\end{array}$ & $\begin{array}{l}\text { Mecânico (Tecnologia e } \\
\text { Desenvolvimento) }\end{array}$ & $\begin{array}{l}\text { RH2008: } \\
165\end{array}$ \\
\hline
\end{tabular}

\begin{tabular}{|l|l|l|l|}
\hline Palavra & Etimologia provável & Significado & Fonte \\
\hline $\begin{array}{l}\text { Mekanisá } \\
\text { [mekani'sa] }\end{array}$ & $<$ Mecanizar & Mecanizar (Tecnologia e & RH2008: \\
& & Desenvolvimento) & 165 \\
\hline
\end{tabular}

236 Varia com mashinista ${ }_{329}$ 


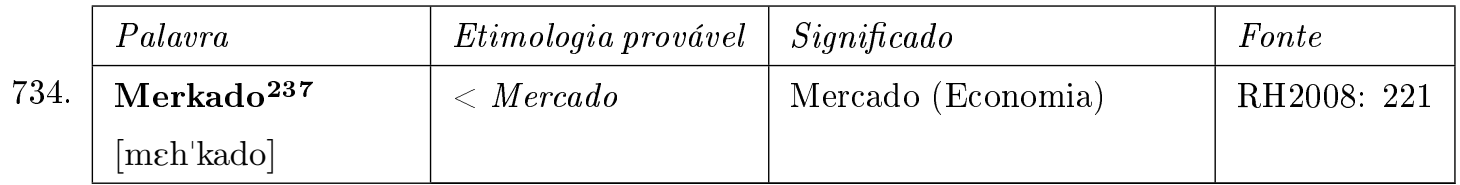

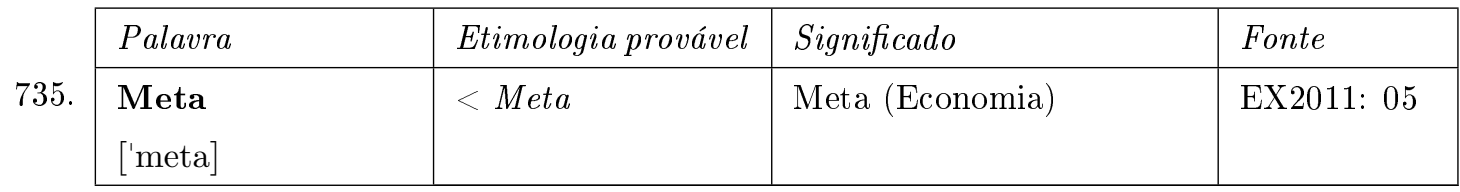

\begin{tabular}{|l|l|l|l|}
\hline Palavra & Etimologia provável & Significado & Fonte \\
\hline Mikroeletrónika & $<$ Microeletrônica & Microeletrônica (Tecnolo- & RH2008: \\
['mikro] & $\mathrm{PT} \mathrm{/} \mathrm{Microeletró-}$ & gia e Desenvolvimento) & 165 \\
[ele'trõnika] & nica ESP & & \\
\hline
\end{tabular}

737.

\begin{tabular}{|l|l|l|l|}
\hline Palavra & Etimologia provável & Significado & Fonte \\
\hline Mikroskopia & $<$ Microscopia & Microscopia (Tecnologia e & RH2008: \\
[mikrosko'pia] & & Desenvolvimento) & 167 \\
& & & \\
\hline
\end{tabular}

738.

\begin{tabular}{|l|l|l|l|}
\hline Palavra & Etimologia provável & Significado & Fonte \\
\hline $\begin{array}{l}\text { Mikroskópiko } \\
\text { [mikros'kəpikə] }\end{array}$ & $<$ Microscópico & Microscópico (Tecnologia e & RH2008: \\
& & Desenvolvimento) & 167 \\
\hline
\end{tabular}

739 .

\begin{tabular}{|l|l|l|l|}
\hline Palavra & Etimologia provável & Significado & Fonte \\
\hline $\begin{array}{l}\text { Ministro } \\
\text { [mi'nistro }]\end{array}$ & $<$ Ministro & Ministro (Política) & H44: 20 \\
\hline
\end{tabular}

740 .

\begin{tabular}{|l|l|l|l|}
\hline Palavra & Etimologia provável & Significado & Fonte \\
\hline $\begin{array}{l}\text { Monetario } \\
\text { [mõne'tario }]\end{array}$ & $\begin{array}{l}<\text { Monetário PT / } \\
\text { Monetario ESP }\end{array}$ & Monetário (Economia) & RH2008: 169 \\
\hline
\end{tabular}

741.

\begin{tabular}{|l|l|l|l|}
\hline Palavra & Etimologia provável & Significado & Fonte \\
\hline $\begin{array}{l}\text { Montante } \\
\text { [mõ'tãte }]\end{array}$ & $<$ Montante & Montante (Economia) & HH88: 38 \\
\hline
\end{tabular}

742.

\begin{tabular}{|l|l|l|l|}
\hline Palavra & Etimologia provável & Significado & Fonte \\
\hline Motor & $<$ Motor & Motor (Tecnologia e De- & RH2008: \\
[mo'toh] & senvolvimento) & 171 \\
& & & \\
\hline
\end{tabular}

\footnotetext{
237 Varia com marshé 892 e waf ${ }_{957}$.
} 


\begin{tabular}{|l|l|l|l|}
\hline Palavra & Etimologia provável & Significado & Fonte \\
\hline Motosikleta & $<$ Motocicleta & Motocicleta (Tecnologia e & RH2008: \\
[motosi'kleta] & & Desenvolvimento) & 171 \\
& & & \\
\hline
\end{tabular}

744.

\begin{tabular}{|l|l|l|l|}
\hline Palavra & Etimologia provável & Significado & Fonte \\
\hline Multimedia & $<$ Multimídia PT / & Multimídia (Tecnologia e & RH2008: \\
[mułti'media] & Multimedia ESP & Desenvolvimento) & 171 \\
& & & \\
\hline
\end{tabular}

745.

\begin{tabular}{|l|l|l|l|}
\hline Palavra & Etimologia provável & Significado & Fonte \\
\hline Múltimionario & $<$ Multimilionário & Multimilio-nário (Econo- & RH2008: 171 \\
[mułtimjo'nario] & $\begin{array}{l}\mathrm{PT} / \text { Multimiliona- } \\
\text { rio ESP }\end{array}$ & mia) & \\
\hline
\end{tabular}

746.

\begin{tabular}{|l|l|l|l|}
\hline Palavra & Etimologia provável & Significado & Fonte \\
\hline $\begin{array}{l}\text { Múltinashonal } \\
\text { [mułtinafõ'nał }]\end{array}$ & $<$ Multinacional & Multinacio-nal (Economia) & RH2008: 171 \\
\hline
\end{tabular}

747.

\begin{tabular}{|l|l|l|l|}
\hline Palavra & Etimologia provável & Significado & Fonte \\
\hline Narkótika & $<$ Narcótico & Narcóticos (Tecnologia e & RH2008: \\
[nah'kotika] & & Desenvolvimento) & 174 \\
& & & \\
\hline
\end{tabular}

748.

\begin{tabular}{|l|l|l|l|}
\hline Palavra & Etimologia provável & Significado & Fonte \\
\hline Narkotisá & $<$ Narcotizar & Narcotizar (Tecnologia e & RH2008: \\
[nahkoti'sa] & & Desenvolvimento) & 174 \\
& & & \\
\hline
\end{tabular}

749.

\begin{tabular}{|l|l|l|l|}
\hline Palavra & Etimologia provável & Significado & Fonte \\
\hline $\begin{array}{l}\text { Narkotráfiko } \\
\text { [nahko'trafiko] }\end{array}$ & $<$ Narcotráfico & Tráfico de entorpecentes & RH2008: \\
& & $\begin{array}{l}\text { ou drogas (Tecnologia e } \\
\text { Desenvolvimento) }\end{array}$ & 174 \\
\hline
\end{tabular}

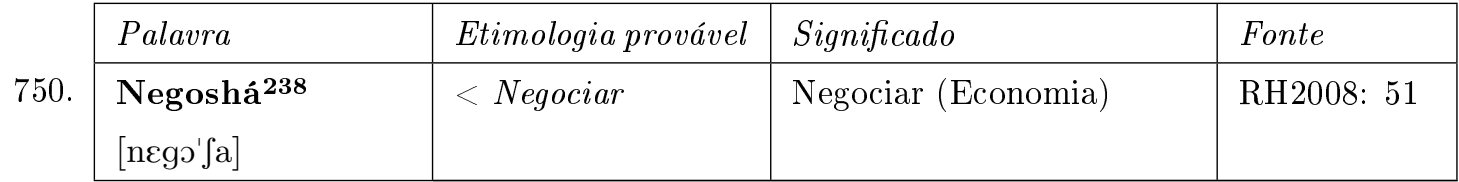

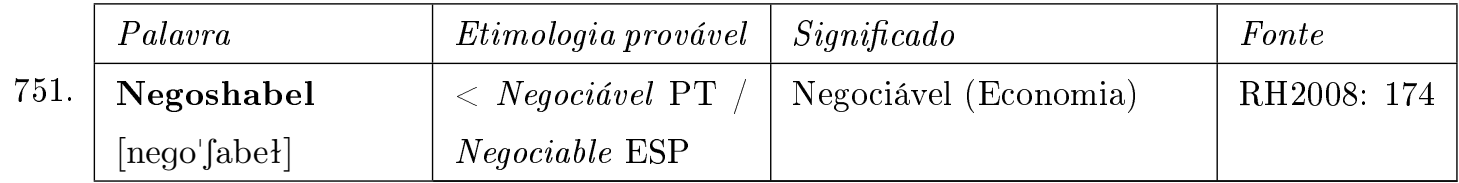

${ }^{238}$ Varia com $d i l_{426}$. 


\begin{tabular}{|c|c|c|c|}
\hline Palavra & Etimologia provável & Significado & Fonte \\
\hline $\begin{array}{l}\text { Negoshamentu } \\
\text { [negofa'mẽtu] }\end{array}$ & $\longleftarrow$ Negociar & Negociação (Economia) & RH2008: 174 \\
\hline
\end{tabular}

\begin{tabular}{|l|l|l|l|}
\hline Palavra & Etimologia provável & Significado & Fonte \\
\hline $\begin{array}{l}\text { Negoshante } \\
\text { [nego'fãte] }\end{array}$ & $<$ Negociante & $\begin{array}{l}\text { Negociante, empresário } \\
\text { (Economia) }\end{array}$ & RH2008: 175 \\
& & & \\
\hline
\end{tabular}

754.

\begin{tabular}{|l|l|l|l|}
\hline Palavra & Etimologia provável & Significado & Fonte \\
\hline $\begin{array}{l}\text { Negoshi } \\
{\left[\text { ne'gð } \int \mathrm{i}\right]}\end{array}$ & $<$ Negócio PT / & Negócio (Economia) & RH2008: 133 \\
\hline
\end{tabular}

755

\begin{tabular}{|l|l|l|l|}
\hline Palavra & Etimologia provável & Significado & Fonte \\
\hline $\begin{array}{l}\text { Nobato } \\
\text { [no'bato] }\end{array}$ & $<$ Novato & $\begin{array}{l}\text { Novato (beisebol) (Es- } \\
\text { porte) }\end{array}$ & D86: 172 \\
& & & \\
\hline
\end{tabular}

756.

\begin{tabular}{|l|l|l|l|}
\hline Palavra & Etimologia provável & Significado & Fonte \\
\hline Nobo & $<$ Novo & Notícia (Tecnologia e De- & RH2008: \\
['nobo] & & senvolvimento) & 176 \\
& & & \\
\hline
\end{tabular}

\begin{tabular}{|l|l|l|l|}
\hline Palavra & Etimologia provável & Significado & Fonte \\
\hline $\begin{array}{l}\text { Nogoshante } \\
\text { [nogo'fãte] }\end{array}$ & $<$ Negociante & $\begin{array}{l}\text { Negociante, empresário } \\
\text { (Economia) }\end{array}$ & RH2008: 175 \\
& & & \\
\hline
\end{tabular}

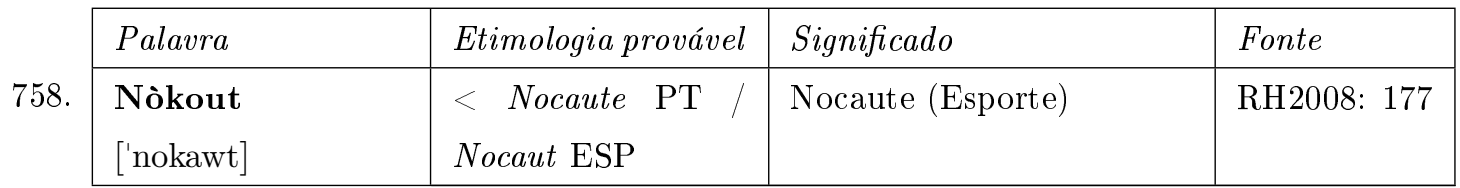

\begin{tabular}{|l|l|l|l|}
\hline Palavra & Etimologia provável & Significado & Fonte \\
\hline N59. & $<$ Notário PT / & Tabelião, notário (Econo- & HH88: 36 \\
[no'tario $]$ & Notario ESP & mia) & \\
& & & \\
\hline
\end{tabular}

\begin{tabular}{|l|l|l|l|}
\hline Palavra & Etimologia provável & Significado & Fonte \\
\hline $\begin{array}{l}\text { Notisia } \\
\text { [no'tisia }]\end{array}$ & $<$ Notícia & $\begin{array}{l}\text { Notícia (Tecnologia e De- } \\
\text { senvolvimento) }\end{array}$ & $\begin{array}{l}\text { RH2008: } \\
177\end{array}$ \\
\hline
\end{tabular}




\begin{tabular}{|l|l|l|l|}
\hline Palavra & Etimologia provável & Significado & Fonte \\
\hline $\begin{array}{l}\text { Nuklear } \\
\text { [nukle'ah] }\end{array}$ & $<$ Nuclear & $\begin{array}{l}\text { Nuclear (Tecnologia e De- } \\
\text { senvolvimento) }\end{array}$ & RH2008: \\
& & & 174 \\
\hline
\end{tabular}

\begin{tabular}{|l|l|l|l|}
\hline Palavra & Etimologia provável & Significado & Fonte \\
\hline N62. & $<$ Nulo & Lançamento que não tem & D86: 172 \\
['nulo] & & $\begin{array}{l}\text { validade (beisebol) (Es- } \\
\text { porte) }\end{array}$ & \\
& & & \\
\hline
\end{tabular}

\begin{tabular}{|c|c|c|c|c|}
\hline \multirow[b]{2}{*}{763.} & Palavra & Etimologia provável & Significado & Fonte \\
\hline & $\begin{array}{l}\text { Olimpiada } \\
\text { [o'lĩpiada }]\end{array}$ & $\begin{array}{l}<\text { Olimpiadas } \mathrm{PT} / \\
\text { Olimpiadas ESP }\end{array}$ & Olímpiadas (Esporte) & RH2008: 181 \\
\hline \multirow[b]{2}{*}{764 . } & Palavra & Etimologia provável & Significado & Fonte \\
\hline & $\begin{array}{l}\text { Olímpiko } \\
\text { [o'lĩpiko] }\end{array}$ & $<$ Olimpico & Olímpico (Esporte) & RH2008: 181 \\
\hline
\end{tabular}

\begin{tabular}{|l|l|l|l|}
\hline Palavra & Etimologia provável & Significado & Fonte \\
\hline $\begin{array}{l}\text { Operadó } \\
{[\text { opera'do] }}\end{array}$ & $<$ Operador & $\begin{array}{l}\text { Operador (Tecnologia e } \\
\text { Desenvolvimento) }\end{array}$ & EX2011: 05 \\
\hline
\end{tabular}

\begin{tabular}{|l|l|l|l|}
\hline 766. & Etimologia provável & Significado & Fonte \\
\cline { 2 - 4 } & $\begin{array}{l}\text { Oroplano } \\
\text { [oro'plãno }]\end{array}$ & $\begin{array}{l}\text { Avião (Tecnologia e Desen- } \\
\text { volvimento) }\end{array}$ & RH2008: 03 \\
\hline
\end{tabular}

\begin{tabular}{|c|c|c|c|c|}
\hline & Palavra & Etimologia provável & Significado & Fonte \\
\hline 767. & $\begin{array}{l}\text { Oumento } \\
\text { [ow'mẽtu] }\end{array}$ & $<$ Aumento & Aumento (Economia) & EX2011: 05 \\
\hline
\end{tabular}

\begin{tabular}{|l|l|l|l|}
\hline Palavra & Etimologia provável & Significado & Fonte \\
\hline Outomátiko & $<$ Automático & Automático (Tecnologia e & RH2008: \\
[owto'matiko] & & Desenvolvimento) & 185 \\
\hline
\end{tabular}

\begin{tabular}{|l|l|l|l|}
\hline Palavra & Etimologia provável & Significado & Fonte \\
\hline $\begin{array}{l}\text { Outomatisá } \\
\text { [owtomati'sa] }\end{array}$ & $<$ Automatizar & $\begin{array}{l}\text { Automatizar (Tecnologia e } \\
\text { Desenvolvimento) }\end{array}$ & RH2008: \\
\hline
\end{tabular}

239 Varia com avion $_{27}$, avioneta $_{28}$ e aeroplano ${ }_{542}$. 
770

\begin{tabular}{|l|l|l|l|}
\hline Palavra & Etimologia provável & Significado & Fonte \\
\hline $\begin{array}{l}\text { Outomatismo } \\
\text { [owtoma'tismo] }\end{array}$ & $<$ Automatismo & $\begin{array}{l}\text { Automatis-mo (Tecnologia } \\
\text { e Desenvolvimento) }\end{array}$ & RH2008: \\
& & & 185 \\
\hline
\end{tabular}

771.

\begin{tabular}{|l|l|l|l|}
\hline Palavra & Etimologia provável & Significado & Fonte \\
\hline $\begin{array}{l}\text { Outomobilista } \\
\text { [owtomobi'lista] }\end{array}$ & $<$ Automobilista & $\begin{array}{l}\text { Automobilis-ta (Tecnolo- } \\
\text { gia e Desenvolvimento) }\end{array}$ & $\begin{array}{l}\text { RH2008: } \\
\end{array}$ \\
& & & \\
\hline
\end{tabular}

772.

\begin{tabular}{|l|l|l|l|}
\hline Palavra & Etimologia provável & Significado & Fonte \\
\hline Pasashi & $<$ Passagem PT, & Passagem (Tecnologia e & RH2008: \\
[pa'saji $]$ & Pasaje ESP & Desenvolvimento) & 245 \\
& & & \\
\hline
\end{tabular}

773.

\begin{tabular}{|l|l|l|l|}
\hline Palavra & Etimologia provável & Significado & Fonte \\
\hline $\begin{array}{l}\text { Pase } \\
\text { ['pase] }\end{array}$ & $<$ Passe PT / Pase & Passe (futebol) (Esporte) & RH2008: 192 \\
\hline
\end{tabular}

774.

\begin{tabular}{|l|l|l|l|}
\hline Palavra & Etimologia provável & Significado & Fonte \\
\hline Pekunario & $<$ Pecuniário PT / & Pecuniária, monetária, fi- & RH2008: 194 \\
[peku'nario] & Pecuniario ESP & nanceira (Economia) & \\
& & & \\
\hline
\end{tabular}

775 .

\begin{tabular}{|l|l|l|l|}
\hline Palavra & Etimologia provável & Significado & Fonte \\
\hline $\begin{array}{l}\text { Pekunio } \\
\text { 240 }\end{array}$ pe'kunio] & $\begin{array}{l}<\text { Pecúnia PT / } \\
\text { Pecunia ESP }\end{array}$ & Dinheiro (Economia) & RH2008: 194 \\
\hline
\end{tabular}

776.

\begin{tabular}{|l|l|l|l|}
\hline Palavra & Etimologia provável & Significado & Fonte \\
\hline $\begin{array}{l}\text { Peso } \\
\text { ['peso] }\end{array}$ & $<$ Peso & Peso (Esporte) & P92: 25 \\
\hline
\end{tabular}

777.

\begin{tabular}{|l|l|l|l|}
\hline Palavra & Etimologia provável & Significado & Fonte \\
\hline $\begin{array}{l}\text { Petrolero } \\
\text { [petro'lero] }\end{array}$ & $<$ Petroleiro & $\begin{array}{l}\text { Petroleiro (Tecnologia e } \\
\text { Desenvolvimento) }\end{array}$ & EX2011: 05 \\
& & & \\
\hline
\end{tabular}

778.

\begin{tabular}{|l|l|l|l|}
\hline Palavra & Etimologia provável & Significado & Fonte \\
\hline $\begin{array}{l}\text { Petroli } \\
\text { [pe'troli }]\end{array}$ & $<$ Petróleo & $\begin{array}{l}\text { Petróleo (Tecnologia e De- } \\
\text { senvolvimento) }\end{array}$ & RH2008: 198 \\
& & & \\
\hline
\end{tabular}

${ }^{240}$ Varia com plaka $a_{782}$. 
779.

\begin{tabular}{|l|l|l|l|}
\hline Palavra & Etimologia provável & Significado & Fonte \\
\hline $\begin{array}{l}\text { Petrologia } \\
\text { [pe'trol’'hia] }\end{array}$ & $<$ Petrologia & $\begin{array}{l}\text { Petrologia (Tecnologia e } \\
\text { Desenvolvimento) }\end{array}$ & RH2008: 198 \\
& & & \\
\hline
\end{tabular}

780.

\begin{tabular}{|l|l|l|l|}
\hline Palavra & Etimologia provável & Significado & Fonte \\
\hline $\begin{array}{l}\text { Piloto } \\
\text { 241 }\end{array}$ pi'loto $]$ & $<$ Piloto & $\begin{array}{l}\text { Piloto (Tecnologia e De- } \\
\text { senvolvimento) }\end{array}$ & RH2008: 198 \\
& & & \\
\hline
\end{tabular}

781.

\begin{tabular}{|l|l|l|l|}
\hline Palavra & Etimologia provável & Significado & Fonte \\
\hline $\begin{array}{l}\text { Pinalti } \\
\text { ['pinałti }]\end{array}$ & $\begin{array}{l}<\text { Pênalti } \mathrm{PT} / P e- \\
\text { nalti ESP }\end{array}$ & Pênalti (Esporte) & RH2008: 198 \\
\hline
\end{tabular}

782.

\begin{tabular}{|l|l|l|l|}
\hline Palavra & Etimologia provável & Significado & Fonte \\
\hline $\begin{array}{l}\text { Plaka } \\
\text { ['plaka }]\end{array}$ & $<$ Placa & Dinheiro (Economia) & RH2008: 169 \\
\hline
\end{tabular}

783.

\begin{tabular}{|l|l|l|l|}
\hline Palavra & Etimologia provável & Significado & Fonte \\
\hline $\begin{array}{l}\text { Podium } \\
\text { ['powdiã] }\end{array}$ & $<$ Podium & Podium (Esporte) & EX2011: 10 \\
\hline
\end{tabular}

784.

\begin{tabular}{|l|l|l|l|}
\hline Palavra & Etimologia provável & Significado & Fonte \\
\hline $\begin{array}{l}\text { Polítika } \\
\text { [po'litika] }\end{array}$ & $<$ Política & Política (Política) & RH2008: \\
& & & 202 \\
\hline
\end{tabular}

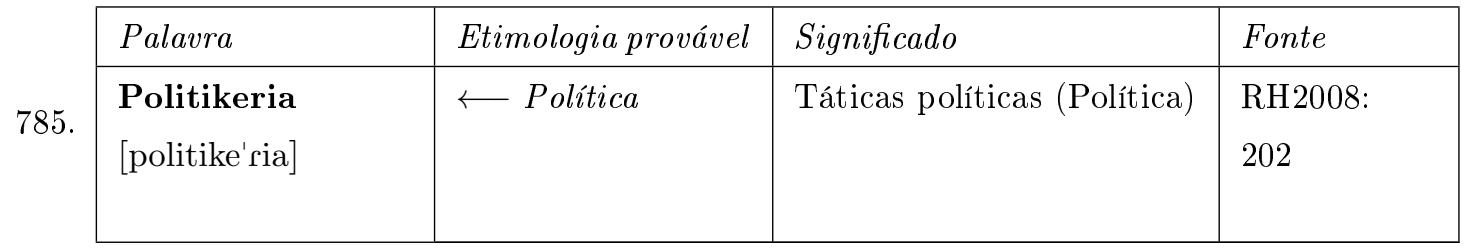

\begin{tabular}{|l|l|l|l|}
\hline Palavra & Etimologia provável & Significado & Fonte \\
\cline { 2 - 4 } & $\begin{array}{l}\text { Polítiko } \\
{[\text { po'litiko }]}\end{array}$ & Político (Política) & $\begin{array}{l}\text { RH2008: } \\
202\end{array}$ \\
\hline
\end{tabular}

241 Varia com pilot 343 .

242 Varia com pekunio ${ }_{775}$. 
787.

\begin{tabular}{|l|l|l|l|}
\hline Palavra & Etimologia provável & Significado & Fonte \\
\hline Polo-akuatiko 243 & $<$ Pólo-aquático & Pólo-aquático (Esporte) & RH2008: 27 \\
['polo] [a'kwatiko] & $\begin{array}{l}\text { PT / Polo acuático } \\
\text { ESP }\end{array}$ & & \\
& & & \\
\hline
\end{tabular}

788

\begin{tabular}{|l|l|l|l|}
\hline Palavra & Etimologia provável & Significado & Fonte \\
\hline $\begin{array}{l}\text { Poloakuatiko } \\
\text { ['polo] [a'kwatiko] }\end{array}$ & $\begin{array}{l}\text { PT / Pólo-aquático acuático } \\
\text { ESP }\end{array}$ & Pólo-aquático (Esporte) & RH2008: 27 \\
& & \\
\hline
\end{tabular}

789

\begin{tabular}{|l|l|l|l|}
\hline Palavra & Etimologia provável & Significado & Fonte \\
\hline Postal & $<$ Postal & Postal (Tecnologia e De- & RH2008: \\
[pos'tał $]$ & & senvolvimento) & 203 \\
& & & \\
\hline
\end{tabular}

790.

\begin{tabular}{|l|l|l|l|}
\hline Palavra & Etimologia provável & Significado & Fonte \\
\hline Postemporada & $<$ Pós-temporada & Pós-temporada (Esporte) & H44: 27 \\
[postẽpo'rada] & PT / Postemporada & & \\
& ESP & & \\
\hline
\end{tabular}

791.

\begin{tabular}{|l|l|l|l|}
\hline Palavra & Etimologia provável & Significado & Fonte \\
\hline $\begin{array}{l}\text { Prepago } \\
\text { [pre'pago] }\end{array}$ & $<$ Pré-pago & $\begin{array}{l}\text { Pré-pago (Tecnologia e De- } \\
\text { senvolvimento) }\end{array}$ & EX2011: \\
& & & 05 \\
\hline
\end{tabular}

792.

\begin{tabular}{|l|l|l|l|}
\hline Palavra & Etimologia provável & Significado & Fonte \\
\hline $\begin{array}{l}\text { Preparadò físiko } \\
\text { [prepara'do] ['fi- } \\
\text { siko] }\end{array}$ & $<$ Preparador físico & Preparador físico (Es- & EX2011: 10 \\
porte) & & \\
\hline
\end{tabular}

793.

\begin{tabular}{|l|l|l|l|}
\hline Palavra & Etimologia provável & Significado & Fonte \\
\hline Presidensia & $<$ Presidência PT / & Presidência (Política) & RH2008: \\
[presi'dẽsia] & Presidencia ESP & & 284 \\
& & & \\
\hline
\end{tabular}

794.

\begin{tabular}{|l|l|l|l|}
\hline Palavra & Etimologia provável & Significado & Fonte \\
\hline $\begin{array}{l}\text { Presidènt } \\
\text { [presi'dẽt] }\end{array}$ & $<$ Presidente & Presidente (Política) & RH2008: \\
& & & 284 \\
\hline
\end{tabular}

243 Varia com Poloakuatiko 788 .

244 Varia com Polo-akuatiko 787. 


\begin{tabular}{|l|l|l|l|}
\hline Palavra & Etimologia provável & Significado & Fonte \\
\hline $\begin{array}{l}\text { Presidente } \\
\text { [presi'dẽte] }\end{array}$ & $<$ Presidente & Presidente (Política) & RH2008: \\
& & & 284 \\
\hline
\end{tabular}

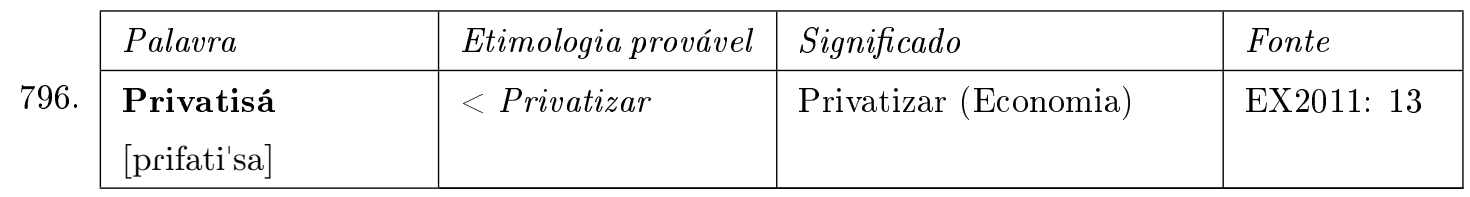

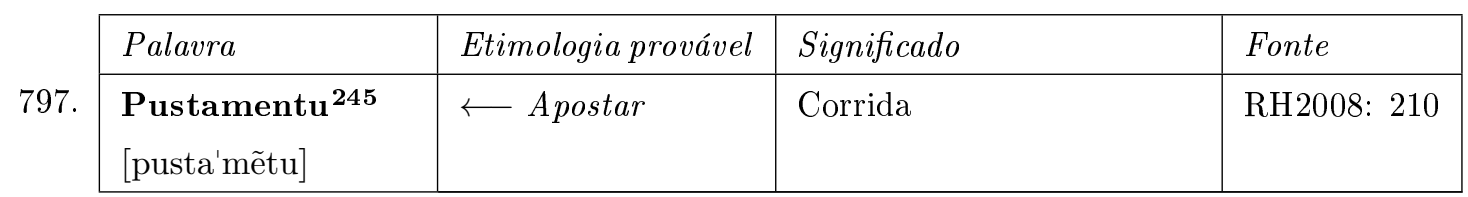

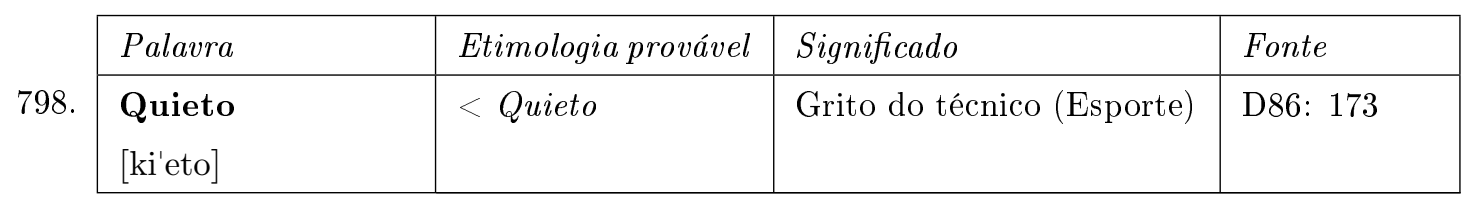

\begin{tabular}{|l|l|l|l|}
\hline Palavra & Etimologia provável & Significado & Fonte \\
\cline { 2 - 4 } & Radio & Rádio & $\begin{array}{l}\text { Rádio (Tecnologia e Desen- } \\
\text { ['radio] }\end{array}$ \\
& & Rolvimento) & 211 \\
\hline
\end{tabular}

\begin{tabular}{|c|c|c|c|c|}
\hline & Palavra & Etimologia provável & Significado & Fonte \\
\hline 800 . & $\begin{array}{l}\text { Radiografia } \\
\text { [xadiogra'fia] }\end{array}$ & $<$ Radiografia & $\begin{array}{l}\text { Radiografia (Tecnologia e } \\
\text { Desenvolvimento) }\end{array}$ & $\begin{array}{l}\text { RH2008: } \\
211\end{array}$ \\
\hline & Palavra & Etimologia provável & Significado & Fonte \\
\hline 801. & $\begin{array}{l}\text { Radiográfiko } \\
\text { [xadio'grafiko] }\end{array}$ & $<$ Radiográfico & $\begin{array}{l}\text { Radiográfico (Tecnologia e } \\
\text { Desenvolvimento) }\end{array}$ & $\begin{array}{l}\text { RH2008: } \\
211\end{array}$ \\
\hline & Palavra & Etimologia provável & Significado & Fonte \\
\hline 802. & $\begin{array}{l}\text { Radiografo } \\
\text { [xadi'ografo] }\end{array}$ & $<$ Radiógrafo & $\begin{array}{l}\text { Radiógrafo (Tecnologia e } \\
\text { Desenvolvimento) }\end{array}$ & $\begin{array}{l}\text { RH2008: } \\
65\end{array}$ \\
\hline \multirow[b]{2}{*}{803.} & Palavra & Etimologia provável & Significado & Fonte \\
\hline & $\begin{array}{l}\text { Rèket } \\
\text { ['rekct] }\end{array}$ & $\begin{array}{l}<\text { Raquete } \mathrm{PT} / \\
\text { Racket } \mathrm{ESP}\end{array}$ & Raquete (tênis) (Esporte) & RH2008: 216 \\
\hline
\end{tabular}

245 Varia com kared $a_{135}$ 


\begin{tabular}{|l|l|l|l|}
\hline Palavra & Etimologia provável & Significado & Fonte \\
\hline Relevo & $<$ Relevo & Lançador que substitui o & D86: 174 \\
[xe'lefo] & & outro (beisebol) (Esporte) & \\
& & & \\
\hline
\end{tabular}

805.

\begin{tabular}{|l|l|l|l|}
\hline Palavra & Etimologia provável & Significado & Fonte \\
\hline $\begin{array}{l}\text { Rema } \\
\text { ['rẽma }]\end{array}$ & $\longleftarrow$ Remar & Remo (Esporte) & P92: 25 \\
\hline
\end{tabular}

806.

\begin{tabular}{|l|l|l|l|}
\hline Palavra & Etimologia provável & Significado & Fonte \\
\hline $\begin{array}{l}\text { Remá } \\
\text { [rẽ'ma }]\end{array}$ & $<$ Remar & Remar (Esporte) & RH2008: 217 \\
\hline
\end{tabular}

807.

\begin{tabular}{|l|l|l|l|}
\hline Palavra & Etimologia provável & Significado & Fonte \\
\hline $\begin{array}{l}\text { Remadó } \\
\text { [rẽma'do }]\end{array}$ & $<$ Remador & Remador (Esporte) & RH2008: 217 \\
\hline
\end{tabular}

808.

\begin{tabular}{|l|l|l|l|}
\hline Palavra & Etimologia provável & Significado & Fonte \\
\hline Remamentu & $\longleftarrow$ Remar & Remada, remadura (Es- & RH2008: 217 \\
[rẽmamẽtu $]$ & porte) & & \\
& & & \\
\hline
\end{tabular}

809.

\begin{tabular}{|l|l|l|l|}
\hline Palavra & Etimologia provável & Significado & Fonte \\
\hline $\begin{array}{l}\text { Rementá } \\
\text { [remẽ'ta }]\end{array}$ & $\begin{array}{l}\text { Arrebentar PT / } \\
\text { Reventar ESP }\end{array}$ & $\begin{array}{l}\text { Estourar (Tecnologia e De- } \\
\text { senvolvimento) }\end{array}$ & RH2008: 65 \\
& & & \\
\hline
\end{tabular}

810.

\begin{tabular}{|l|l|l|l|}
\hline Palavra & Etimologia provável & Significado & Fonte \\
\hline Rendimentu $^{\mathbf{2 4 6}}$ & $<$ Rendimento PT & Rendimento (Economia) & HH88: 31 \\
[rẽdi'mẽtu $]$ & $/$ Rendimiento ESP & & \\
\hline
\end{tabular}

811.

\begin{tabular}{|l|l|l|l|}
\hline Palavra & Etimologia provável & Significado & Fonte \\
\hline $\begin{array}{l}\text { Resibo } \\
\text { [xe'sibo }]\end{array}$ & $<$ Recibo & Recibo (Economia) & RH2008: 221 \\
\hline
\end{tabular}

812.

\begin{tabular}{|l|l|l|l|}
\hline Palavra & Etimologia provável & Significado & Fonte \\
\hline $\begin{array}{l}\text { Revista } \\
\text { [re'fista }]\end{array}$ & $<$ Revista & $\begin{array}{l}\text { Revista (Tecnologia e De- } \\
\text { senvolvimento) }\end{array}$ & 221 \\
& & & \\
\hline
\end{tabular}

246 Varia com rentabiliteit 352. 
813

\begin{tabular}{|l|l|l|l|}
\hline Palavra & Etimologia provável & Significado & Fonte \\
\hline $\begin{array}{l}\text { Rudiyera } \\
\text { [rudi'jera }]\end{array}$ & $\begin{array}{l}<\text { Rodilheira PT / } \\
\text { Rodillera ESP }\end{array}$ & $\begin{array}{l}\text { Protetor corporal (beise- } \\
\text { bol) (Esporte) }\end{array}$ & D86: 174 \\
& & \\
\hline
\end{tabular}

\begin{tabular}{|c|c|c|c|}
\hline Palavra & Etimologia provável & Significado & Fonte \\
\hline $\begin{array}{l}\text { Rugbi } \\
{[\text { 'rəhbi] }}\end{array}$ & $\begin{array}{l}<\text { Rúgbi PT } \\
\text { Rugby ESP }\end{array}$ & $\begin{array}{l}\text { Rúgbi ou rugby, esporte } \\
\text { em que duas equipes de } \\
15 \text { jogadores se enfrentam, } \\
\text { usando as mãos e os pés, } \\
\text { na tentativa de levar a bola } \\
\text { oval até a linha de fundo } \\
\text { adversária ou fazê-la pas- } \\
\text { sar por entre as traves da } \\
\text { meta (Esporte) }\end{array}$ & P92: 48 \\
\hline
\end{tabular}

\begin{tabular}{|c|c|c|c|}
\hline Palavra & Etimologia provável & Significado & Fonte \\
\hline $\begin{array}{l}\text { Salario } \\
\text { [sa'lario] }\end{array}$ & $\begin{array}{l}<\text { Salário PT / Sa- } \\
\text { lario ESP }\end{array}$ & Salário (Economia) & RH2008: 187 \\
\hline
\end{tabular}

\begin{tabular}{|l|l|l|l|l|}
\hline 816. & Palavra & Etimologia provável & Significado & Fonte \\
\cline { 2 - 5 } & Saldo ['sałdo] & $<$ Saldo & Saldo (Economia) & HH88: 18 \\
\hline
\end{tabular}

\begin{tabular}{|l|l|l|l|}
\hline Palavra & Etimologia provável & Significado & Fonte \\
\hline $\begin{array}{l}\text { Sapatu di bola } \\
\text { [sa'patu] [di] ['bola] }\end{array}$ & $\begin{array}{l}\Leftarrow \text { botas de fútbol } \\
\text { ESP, Bola }\end{array}$ & $\begin{array}{l}\text { Chuteira (futebol) (Es- } \\
\text { porte) }\end{array}$ & C2010: 14 \\
\hline
\end{tabular}

\begin{tabular}{|l|l|l|l|}
\hline Palavra & Etimologia provável & Significado & Fonte \\
\hline Seguro di edifi- & $<$ Seguro de edificio & Seguro para moradia (Eco- & HH88: 22 \\
sio $^{\mathbf{2 4 7}}$ & $\mathrm{PT} /$ Seguro de edi- & nomia) & \\
{$\left[\begin{array}{ll}{[\text { se'guro }]} \\
\text { [edi'fisio }]\end{array}\right.$} & ficio ESP & & \\
\hline
\end{tabular}

${ }^{247}$ Varia com opstalverzekering ${ }_{336}$. 


\begin{tabular}{|c|c|c|c|c|}
\hline & Palavra & Etimologia provável & Significado & Fonte \\
\hline 819. & $\begin{array}{l}\text { Seguro di inven- } \\
\text { tario }^{248} \\
\text { [se'guro] } \\
\text { [iffẽtario] }\end{array}$ & $\begin{array}{l}<\text { Seguro de inven- } \\
\text { tário PT / Seguro } \\
\text { de inventario ESP }\end{array}$ & $\begin{array}{l}\text { Seguro de inventário (Eco- } \\
\text { nomia) }\end{array}$ & HH88: 22 \\
\hline & Palavra & Etimologia provável & Significado & Fonte \\
\hline 820. & $\begin{array}{l}\text { Seguro di outo } \\
\left.\left[\mathrm{se}^{\prime \prime} \text { guro] }\right] \mathrm{di}\right] \\
{[\text { 'owto }]}\end{array}$ & $<$ Seguro de auto & $\begin{array}{l}\text { Seguro de carro (Econo- } \\
\text { mia) }\end{array}$ & HH88: 22 \\
\hline
\end{tabular}

\begin{tabular}{|c|c|c|c|c|}
\hline & Palavra & Etimologia provável & Significado & Fonte \\
\hline 821. & $\begin{array}{l}\text { Seguro di res- } \\
\text { ponsabilidat sivil } \\
\text { [se'guro] [di] } \\
\text { [xespõsabili'dat] } \\
{[\text { 'sifił } \Lambda]}\end{array}$ & $\begin{array}{l}<\text { Seguro de respon- } \\
\text { sabilidade civil }\end{array}$ & $\begin{array}{l}\text { Seguro de responsabilidade } \\
\text { legal (Economia) }\end{array}$ & HH88: 22 \\
\hline
\end{tabular}

\begin{tabular}{|l|l|l|l|}
\hline 822. & Etimologia provável & Significado & Fonte \\
\hline $\begin{array}{l}\text { Selular } \\
\text { [selu'lah }]\end{array}$ & $<$ Celular & $\begin{array}{l}\text { Celular (Tecnologia e De- } \\
\text { senvolvimento) }\end{array}$ & EX2011:04 \\
& & & \\
\hline
\end{tabular}

\begin{tabular}{|c|c|c|c|c|}
\hline & Palavra & Etimologia provável & Significado & Fonte \\
\hline 823. & $\begin{array}{l}\text { Semi final } \\
\text { ['semi] [fi'nał] }\end{array}$ & $\begin{array}{l}<\text { Semi-final PT } / \\
\text { Semifinal ESP }\end{array}$ & Semi-final (Esporte) & EX2011: 03 \\
\hline
\end{tabular}

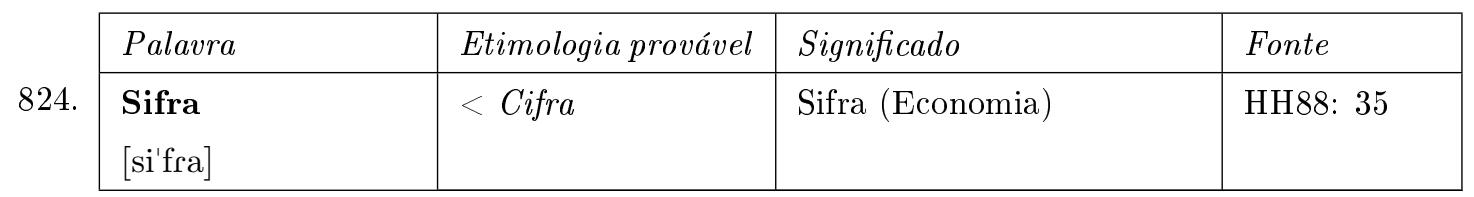

\begin{tabular}{|c|c|c|c|c|}
\hline & Palavra & Etimologia provável & Significado & Fonte \\
\hline 825. & $\begin{array}{l}\text { Siklismo } \\
\text { [si'klismo] }\end{array}$ & $<$ Ciclismo & Ciclismo (Esporte) & EX2011: 10 \\
\hline
\end{tabular}

\begin{tabular}{|c|c|c|c|c|}
\hline & Palavra & Etimologia provável & Significado & Fonte \\
\hline 826. & $\begin{array}{l}\text { Siklista } \\
\text { [si'klista] }\end{array}$ & $<$ Ciclista & Ciclista (Esporte) & EX2011: 10 \\
\hline
\end{tabular}

827. \begin{tabular}{|l|l|l|l|}
\hline Palavra & Etimologia provável & Significado & Fonte \\
\hline $\begin{array}{l}\text { Sindikal } \\
\text { [sidi'kał] }\end{array}$ & $<$ Sindical & Sindical (Política) & EX2011: 05 \\
\hline
\end{tabular}

248 Varia com inventariszakering ${ }_{304}$. 


\begin{tabular}{|c|c|c|c|}
\hline Palavra & Etimologia provável & Significado & Fonte \\
\hline $\begin{array}{l}\text { Sindikato } \\
\text { [sĩdi'kato] }\end{array}$ & $<$ Sindicato & Sindicato (Política) & EX2011: 05 \\
\hline
\end{tabular}

829.

\begin{tabular}{|l|l|l|l|}
\hline Palavra & Etimologia provável & Significado & Fonte \\
\hline $\begin{array}{l}\text { Sine } \\
\text { ['sine] }\end{array}$ & $<$ Cine & $\begin{array}{l}\text { Cinema (Tecnologia e De- } \\
\text { senvolvimento) }\end{array}$ & RH2008: 136 \\
\hline
\end{tabular}

830.

\begin{tabular}{|l|l|l|l|}
\hline Palavra & Etimologia provável & Significado & Fonte \\
\hline $\begin{array}{l}\text { Sineasta } \\
\text { [si'neasta] }\end{array}$ & $<$ Cineasta & $\begin{array}{l}\text { Cineasta (Tecnologia e De- } \\
\text { senvolvimento) }\end{array}$ & RH2008: \\
& & & \\
\hline
\end{tabular}

831.

\begin{tabular}{|l|l|l|l|}
\hline Palavra & Etimologia provável & Significado & Fonte \\
\hline $\begin{array}{l}\text { Sinematografia } \\
\text { [sinematogra'fia }]\end{array}$ & $<$ Cinematografia & $\begin{array}{l}\text { Cinematogra-fia (Tecnolo- } \\
\text { gia e Desenvolvimento) }\end{array}$ & $\begin{array}{l}\text { RH2008: } \\
236\end{array}$ \\
\hline
\end{tabular}

832.

\begin{tabular}{|l|l|l|l|}
\hline Palavra & Etimologia provável & Significado & Fonte \\
\hline $\begin{array}{l}\text { Sinematográfiko } \\
\text { [sinemato'grafiko }]\end{array}$ & $<$ Cinematográfico & $\begin{array}{l}\text { Cinematográ-fico (Tecno- } \\
\text { logia e Desenvolvimento) }\end{array}$ & $\begin{array}{l}\text { RH2008: } \\
236\end{array}$ \\
\hline
\end{tabular}

833.

\begin{tabular}{|l|l|l|l|}
\hline Palavra & Etimologia provável & Significado & Fonte \\
\hline $\begin{array}{l}\text { Sinematógrafo } \\
\text { [sinema'tografo] }\end{array}$ & $<$ Cinematógrafo & $\begin{array}{l}\text { Cinemató-grafo (Tecnolo- } \\
\text { gia e Desenvolvimento) }\end{array}$ & $\begin{array}{l}\text { RH2008: } \\
236\end{array}$ \\
\hline
\end{tabular}

\begin{tabular}{|l|l|l|l|l|}
\hline 834. & Palavra & Etimologia provável & Significado & Fonte \\
\cline { 2 - 5 } & $\begin{array}{l}\text { Sirkuito } \\
{[\text { sih'kwitu }]}\end{array}$ & $\begin{array}{l}\text { Circuito (esportivo) (Es- } \\
\text { porte) }\end{array}$ & EX2011: 16 \\
\hline
\end{tabular}

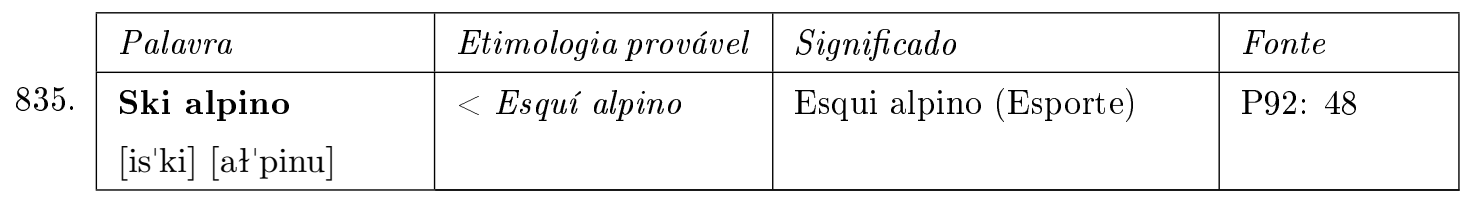

\begin{tabular}{|l|l|l|l|l|}
\hline 836. & Palavra & Etimologia provável & Significado & Fonte \\
\cline { 1 - 4 } & $\begin{array}{l}\text { Solvensia } \\
\text { 249 } \\
\text { [sol'fẽsia }]\end{array}$ & $\begin{array}{l}<\text { Solvência PT / } \\
\text { Solvencia } \text { ESP }\end{array}$ & Solvência (Economia) & HH88: 35 \\
\hline
\end{tabular}

${ }^{249}$ Varia com solvabiliteit ${ }_{374}$. 


\begin{tabular}{|c|c|c|c|}
\hline Palavra & Etimologia provável & Significado & Fonte \\
\hline $\begin{array}{l}\text { Sosio } \\
{[\text { 'sosio] }}\end{array}$ & $\begin{array}{l}<\text { Sócio PT / Socio } \\
\text { ESP }\end{array}$ & Sócio (Economia) & HH88: 33 \\
\hline
\end{tabular}

838.

\begin{tabular}{|l|l|ll|l|}
\hline Palavra & Etimologia provável & Significado & Fonte \\
\hline $\begin{array}{l}\text { Spada } \\
\text { [is'pada }]\end{array}$ & $<$ Espada & $\begin{array}{l}\text { Espada (esgrima) } \\
\text { porte) }\end{array}$ & (Es- & OL93: 19 \\
\hline
\end{tabular}

839.

\begin{tabular}{|l|l|l|l|}
\hline Palavra & Etimologia provável & Significado & Fonte \\
\hline Stashoná & $<$ Estacionar & Estacionar (Tecnologia e & RH2008: \\
[istafõ'na] & & Desenvolvimento) & 245 \\
& & & \\
\hline
\end{tabular}

840.

\begin{tabular}{|l|l|l|l|}
\hline Palavra & Etimologia provável & Significado & Fonte \\
\hline $\begin{array}{l}\text { Stashonamentu } \\
\text { [estafõna'mẽtr] }\end{array}$ & $\begin{array}{l}\text { PT Estacionamento } \\
\text { ento Estacionami- }\end{array}$ & $\begin{array}{l}\text { Estacionamento (Tecnolo- } \\
\text { gia e Desenvolvimento) }\end{array}$ & RH2008: \\
245
\end{tabular}

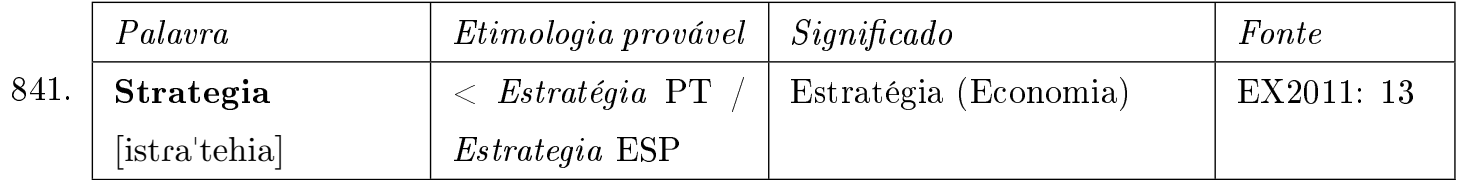

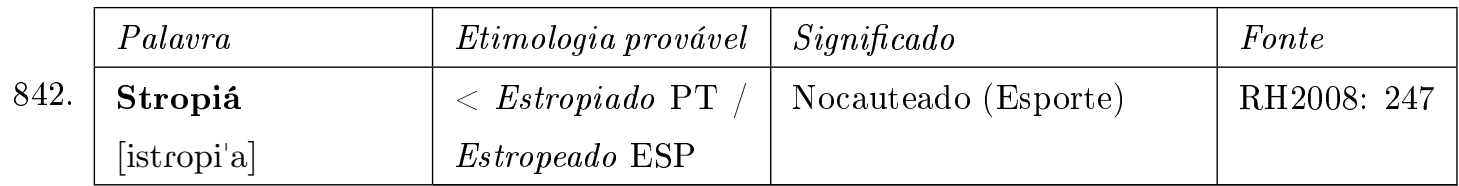

\begin{tabular}{|l|l|l|l|l|}
\hline 843. & Palavra & Etimologia provável & Significado & Fonte \\
\cline { 2 - 4 } & $\begin{array}{l}\text { Supsidiá } \\
\text { [supsidi'a }]\end{array}$ & $<$ Subsidiar & Subsidiar (Economia) & RH2008: 79 \\
\hline
\end{tabular}

\begin{tabular}{|c|c|c|c|c|}
\hline & Palavra & Etimologia provável & Significado & Fonte \\
\hline 844 . & $\begin{array}{l}\text { Supsidio }^{250} \\
\text { [sup'sidio] }\end{array}$ & $\begin{array}{l}<\text { Subsidio PT / } \\
\text { Subsidio ESP }\end{array}$ & Subsídio (Economia) & RH2008: 250 \\
\hline
\end{tabular}

\begin{tabular}{|c|c|c|c|}
\hline Palavra & Etimologia provável & Significado & Fonte \\
\hline $\begin{array}{l}\text { Tae Kwon Do } \\
\text { [tej'kwõdo] }\end{array}$ & $<$ Taekwondo & Tae kwon do (Esporte) & P92: 48 \\
\hline
\end{tabular}

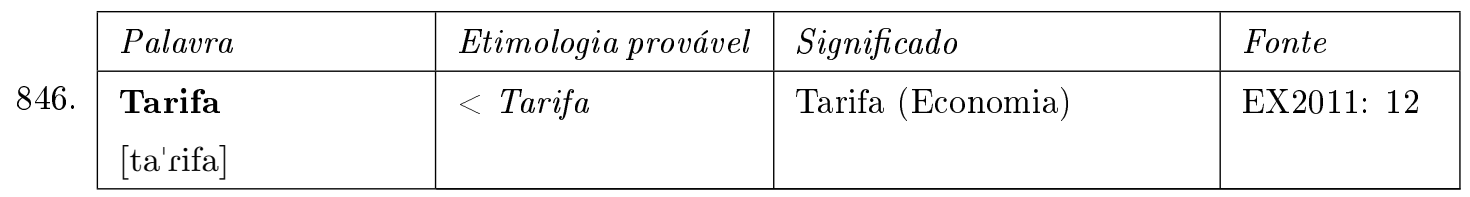

${ }^{250}$ Varia com aporte 551. 


\begin{tabular}{|l|l|l|l|}
\hline 847. & Etimologia provável & Significado & Fonte \\
\hline Teklado $^{\mathbf{2 5 1}}$ & $<$ Teclado & Teclado (Tecnologia e De- & RH2008: \\
[tekla'do] & & senvolvimento) & 254 \\
& & & \\
\hline
\end{tabular}

\begin{tabular}{|c|c|c|c|c|}
\hline & Palavra & Etimologia provável & Significado & Fonte \\
\hline 848. & $\begin{array}{l}\text { Téknika } \\
\text { ['tekinika] }\end{array}$ & $<$ Técnica & Técnica (Esporte) & $\mathrm{H} 44: 13$ \\
\hline
\end{tabular}

\begin{tabular}{|l|l|l|l|}
\hline Palavra & Etimologia provável & Significado & Fonte \\
\hline Tékniko & $<$ Técnico & Técnico (Tecnologia e De- & RH2008: \\
['tekniko] & & senvolvimento) & 254 \\
& & & \\
\hline
\end{tabular}

850 .

\begin{tabular}{|l|l|l|l|}
\hline Palavra & Etimologia provável & Significado & Fonte \\
\hline Telefériko & $<$ Teleférico & Teleférico (Tecnologia e & RH2008: \\
[tele'feriko] & & Desenvolvimento) & 254 \\
& & & \\
\hline
\end{tabular}

851.

\begin{tabular}{|l|l|l|l|}
\hline Palavra & Etimologia provável & Significado & Fonte \\
\hline Telefónikamente & $<$ Telefonicamente & Por telefone (Tecnologia e & RH2008: \\
[telefõnika'mẽte] & PT / Teléfonicami- & Desenvolvimento) & 254 \\
& ente ESP & & \\
\hline
\end{tabular}

852 .

\begin{tabular}{|l|l|l|l|}
\hline Palavra & Etimologia provável & Significado & Fonte \\
\hline Telefóniko & $<$ Telefônico PT / & Telefônico (Tecnologia e & RH2008: \\
[tele'fõniko] & Telefónico ESP & Desenvolvimento) & 254 \\
& & & \\
\hline
\end{tabular}

\begin{tabular}{|l|l|l|l|}
\hline 853. & Etimologia provável & Significado & Fonte \\
\cline { 2 - 5 } & Telefonista & Telefonista (Tecnologia e & RH2008: \\
[telefõ'nista $]$ & Desenvolvimento) & 254 \\
\hline
\end{tabular}

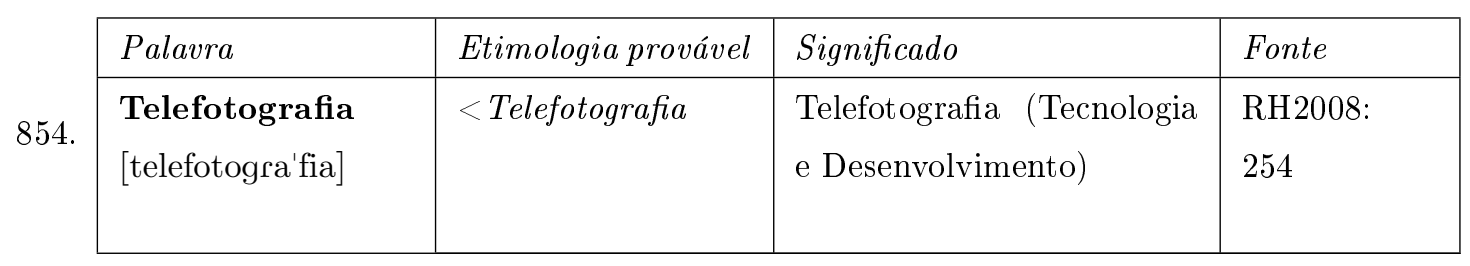

251 Varia com klavier 310 . 
855.

\begin{tabular}{|l|l|l|l|}
\hline Palavra & Etimologia provável & Significado & Fonte \\
\hline $\begin{array}{l}\text { Telefotográfiko } \\
\text { [telefoto'grafiko] }\end{array}$ & $<$ Telefotográfico & $\begin{array}{l}\text { Telefotográfico (Tecnologia } \\
\text { e Desenvolvimento) }\end{array}$ & RH2008: \\
& & & 254 \\
\hline
\end{tabular}

856.

\begin{tabular}{|l|l|l|l|}
\hline Palavra & Etimologia provável & Significado & Fonte \\
\hline $\begin{array}{l}\text { Telefotografo } \\
\text { [telefo'tografo] }\end{array}$ & $<$ Telefotógrafo & Telefotógrafo (Tecnologia e & RH2008: \\
& & Desenvolvimento) & 254 \\
\hline
\end{tabular}

857.

\begin{tabular}{|l|l|l|l|}
\hline Palavra & Etimologia provável & Significado & Fonte \\
\hline $\begin{array}{l}\text { Telegrafia } \\
\text { [telegra'fia] }\end{array}$ & $<$ Telegrafia & Telegrafia (Tecnologia e & RH2008: \\
& & Desenvolvimento) & 254 \\
\hline
\end{tabular}

858.

\begin{tabular}{|l|l|l|l|}
\hline Palavra & Etimologia provável & Significado & Fonte \\
\hline $\begin{array}{l}\text { Telegráfikamente } \\
\text { [tele'grafikamẽte] }\end{array}$ & $\begin{array}{l}<\text { Telegraficamente } \\
\text { PT / Telegráficami- } \\
\text { ente ESP }\end{array}$ & $\begin{array}{l}\text { Telegrafica-mente (Tecno- } \\
\text { logia e Desenvolvimento) }\end{array}$ & 254 \\
\hline
\end{tabular}

859.

\begin{tabular}{|l|l|l|l|}
\hline Palavra & Etimologia provável & Significado & Fonte \\
\hline Telegráfiko & $<$ Telegráfico & Telegráfico (Tecnologia e & RH2008: \\
[tele'grafiko] & & Desenvolvimento) & 254 \\
& & & \\
\hline
\end{tabular}

860.

\begin{tabular}{|l|l|l|l|}
\hline Palavra & Etimologia provável & Significado & Fonte \\
\hline $\begin{array}{l}\text { Telegrafista } \\
\text { [telegra'fista] }\end{array}$ & $<$ Telegrafista & Telegrafista (Tecnologia e & RH2008: \\
& & Desenvolvimento) & 254 \\
\hline
\end{tabular}

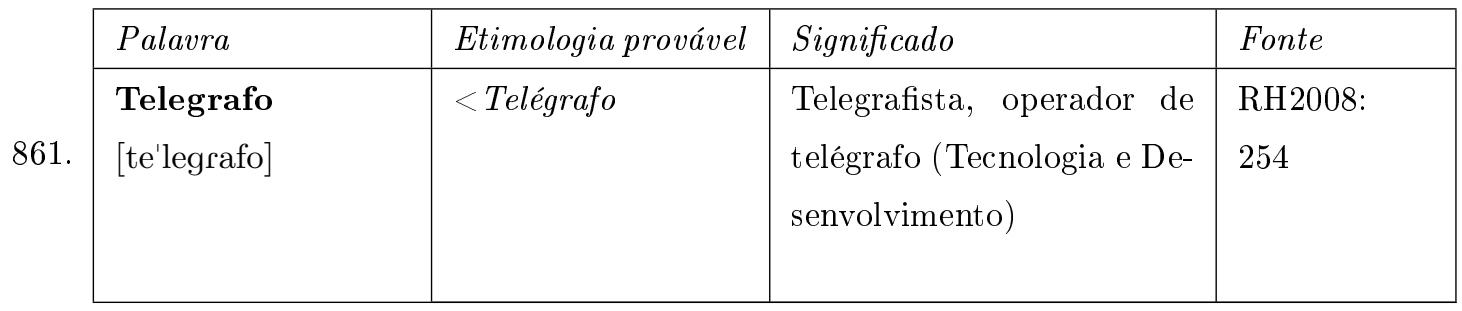

\begin{tabular}{|l|l|l|l|}
\hline Palavra & Etimologia provável & Significado & Fonte \\
\hline 862. & $<$ Televisor & $\begin{array}{l}\text { Aparelho de televisão } \\
\text { (Tecnologia e Desenvolvi- }\end{array}$ & 255 \\
& & $\begin{array}{l}\text { Rento } \\
\text { mento }\end{array}$ & \\
& & & \\
\hline
\end{tabular}




\begin{tabular}{|l|l|l|l|l|}
\hline 863. & Palavra & Etimologia provável & Significado & Fonte \\
\cline { 1 - 4 } & $\begin{array}{l}\text { Tènes } \\
{[\text { 'tenes }]}\end{array}$ & $\begin{array}{l}<\text { Tênis } \mathrm{PT} / \text { Tenis } \\
\text { ESP }\end{array}$ & Tênis (Esporte) & RH2008: 255 \\
\hline
\end{tabular}

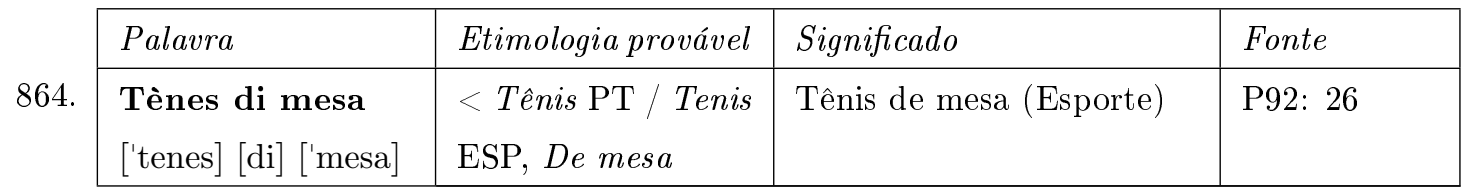

\begin{tabular}{|l|l|l|l|l|}
\hline 865. & Palavra & Etimologia provável & Significado & Fonte \\
\cline { 2 - 4 } & $\begin{array}{l}\text { Tereno } \\
\text { te'reno }]\end{array}$ & $<$ Terreno & Área (Esporte) & H44: 29 \\
\hline
\end{tabular}

\begin{tabular}{|c|c|c|c|}
\hline Palavra & Etimologia provável & Significado & Fonte \\
\hline $\begin{array}{l}\text { Terminal } \\
\text { [tehmi'nał] }\end{array}$ & $<$ Terminal & $\begin{array}{l}\text { Terminal (Tecnologia e De- } \\
\text { senvolvimento) }\end{array}$ & $\begin{array}{l}\text { RH2008: } \\
256\end{array}$ \\
\hline
\end{tabular}

\begin{tabular}{|c|c|c|c|}
\hline Palavra & Etimologia provável & Significado & Fonte \\
\hline $\begin{array}{l}\text { Tiro }^{252} \\
\text { ['tiro] }\end{array}$ & $<$ Tiro & Tiro (Esporte) & P92: 48 \\
\hline
\end{tabular}

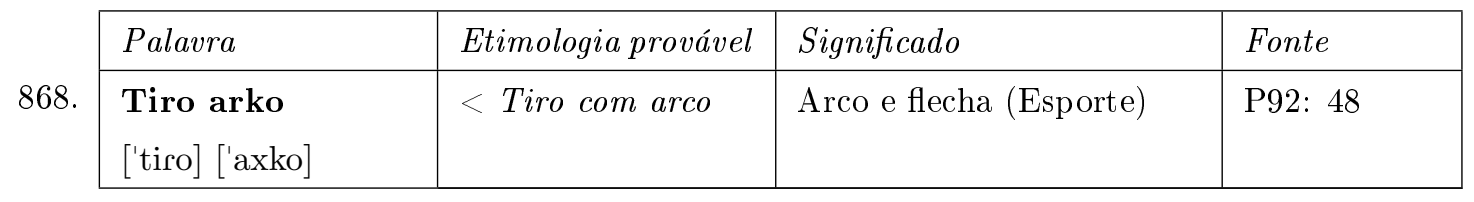

\begin{tabular}{|l|l|l|l|l|}
\hline 869. & Palavra & Etimologia provável & Significado & Fonte \\
\cline { 2 - 4 } & $\begin{array}{l}\text { Tiru } \\
\text { ['tiru }]\end{array}$ & Tiro (Esporte) & P92: 35 \\
\hline
\end{tabular}

\begin{tabular}{|l|l|l|l|l|}
\hline 870. & Palavra & Etimologia provável & Significado & Fonte \\
\cline { 2 - 4 } & $\begin{array}{l}\text { Toke } \\
\text { ['toke] }\end{array}$ & $<$ Toque & Toque (futebol) (Esporte) & OL93: 19 \\
\hline
\end{tabular}

\begin{tabular}{|l|l|l|l|}
\hline Palavra & Etimologia provável & Significado & Fonte \\
\hline Torpediá & $<$ Torpedear & $\begin{array}{l}\text { Atacar com torpedos } \\
\text { (Tecnologia e Desenvolvi- } \\
\text { mento) }\end{array}$ & $\begin{array}{l}\text { RH2008: } \\
259\end{array}$ \\
\hline [tohpedi'a] & & & \\
\hline
\end{tabular}

252 Varia com tiru $_{869}$.

253 Varia com tiro $_{867}$. 
872.

\begin{tabular}{|l|l|l|l|}
\hline Palavra & Etimologia provável & Significado & Fonte \\
\hline $\begin{array}{l}\text { Torpedo } \\
\text { [toh'pedo] }\end{array}$ & $<$ Torpedo & $\begin{array}{l}\text { Torpedo (Tecnologia e De- } \\
\text { senvolvimento) }\end{array}$ & RH2008: \\
& & & 259 \\
\hline
\end{tabular}

873.

\begin{tabular}{|l|l|l|l|}
\hline Palavra & Etimologia provável & Significado & Fonte \\
\hline Trámite & $<$ Trâmite PT / & Transação de negócios, tra- & RH2008: 206 \\
['trãmite] & Trámite ESP & mite (Economia) & \\
& & & \\
\hline
\end{tabular}

\begin{tabular}{|l|l|l|l|l|}
\hline 874. & Palavra & Etimologia provável & Significado & Fonte \\
\cline { 2 - 5 } & $\begin{array}{l}\text { Trapolin } \\
\text { [trãpo'lĩ] }\end{array}$ & $\begin{array}{l}<\text { Trampolim PT / } \\
\text { Trampolín ESP }\end{array}$ & Trapolim (Esporte) & RH2008: 260 \\
\cline { 2 - 5 }
\end{tabular}

\begin{tabular}{|l|l|l|l|}
\hline 8alavra & Etimologia provável & Significado & Fonte \\
\cline { 2 - 3 } & Transmití & Transmitir (Tecnologia e & RH2008:67 \\
[trãsmi'ti] & $<$ Transmitir & Desenvolvimento) & \\
\hline
\end{tabular}

\begin{tabular}{|c|c|c|c|}
\hline Palavra & Etimologia provável & Significado & Fonte \\
\hline $\begin{array}{l}\text { Transportá } \\
\text { [trãspoh'ta] }\end{array}$ & $<$ Transportar & $\begin{array}{l}\text { Transportar (Tecnologia e } \\
\text { Desenvolvimento) }\end{array}$ & EX2011: 04 \\
\hline
\end{tabular}

\begin{tabular}{|l|l|l|l|}
\hline 8alavra & Etimologia provável & Significado & Fonte \\
\cline { 1 - 4 } & $\begin{array}{l}\text { Transporte } \\
\text { [trãs'pohte] }\end{array}$ & $\begin{array}{l}\text { Transporte (Tecnologia e } \\
\text { Desenvolvimento) }\end{array}$ & EX2011: 04 \\
\hline
\end{tabular}

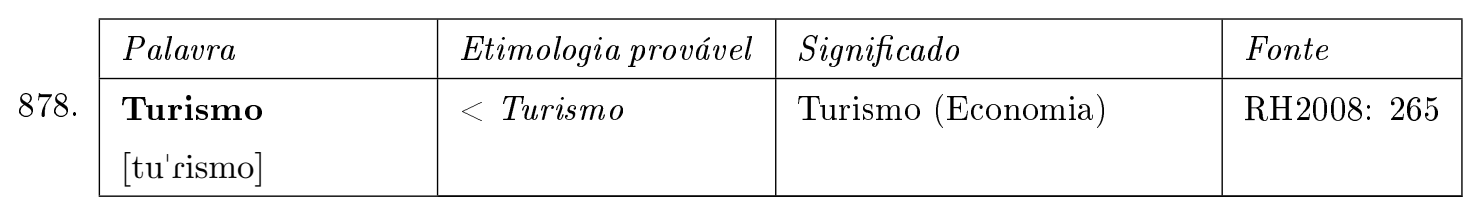

\begin{tabular}{|c|c|c|c|c|}
\hline \multirow[b]{2}{*}{879 . } & Palavra & Etimologia provável & Significado & Fonte \\
\hline & $\begin{array}{l}\text { Turista } \\
\text { [tu'rista] }\end{array}$ & $<$ Turista & Turista (Economia) & RH2008: 265 \\
\hline
\end{tabular}

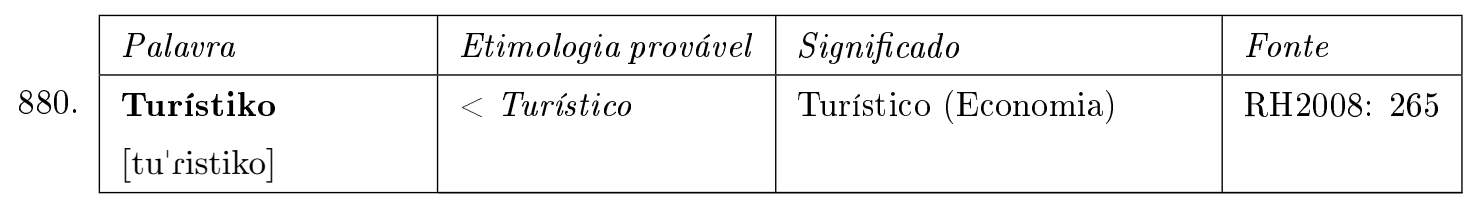




\begin{tabular}{|l|l|l|l|}
\hline 8alavra & Etimologia provável & Significado & Fonte \\
\hline Uranio & $<$ Urânio PT / & Urânio (Tecnologia e De- & RH2008: \\
[u'ranio] & Uranio ESP & senvolvimento) & 267 \\
\hline
\end{tabular}

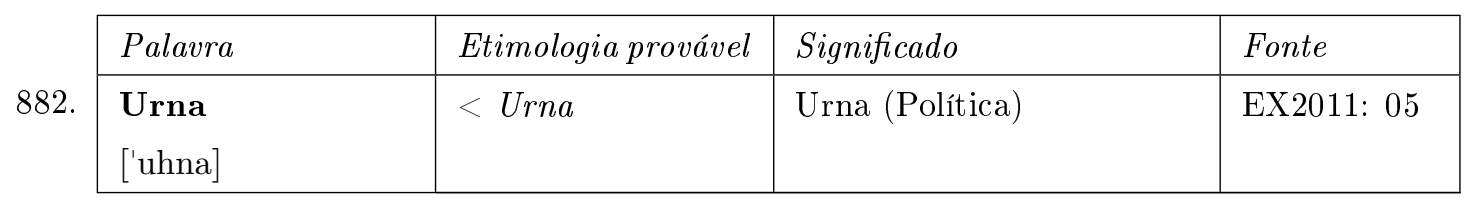

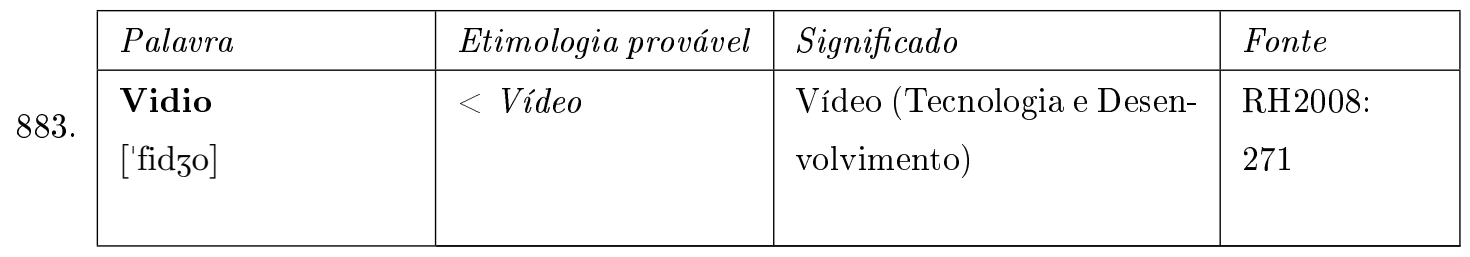

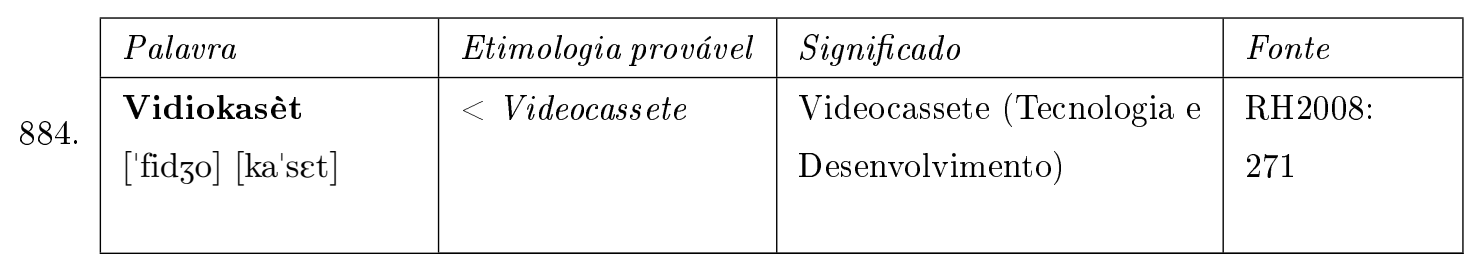

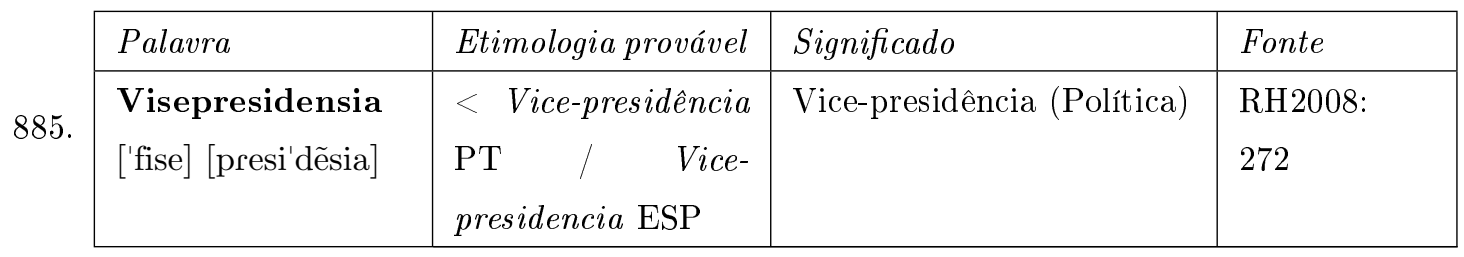

\begin{tabular}{|l|l|l|l|}
\hline 8alavra & Etimologia provável & Significado & Fonte \\
\hline Visepresidente & $<$ Vice-presidente & Vice-presiden-te (Política) & RH2008: \\
['fise] [presi'dẽte] & & & 272 \\
\hline
\end{tabular}

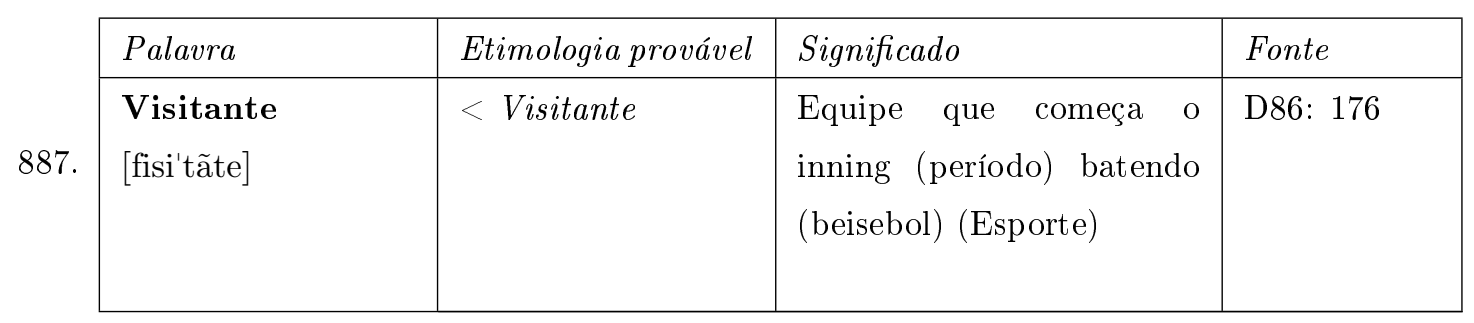

\section{PORTUGUÊS}




\begin{tabular}{|l|l|l|l|}
\hline Palavra & Etimologia provável & Significado & Fonte \\
\hline Kohida & $<$ Corrida & Espécie de pontuação, & D86: 170 \\
[ko'xida $]$ & & $\begin{array}{l}\text { ocorre quando um ata- } \\
\text { cante chega a Casa Base } \\
\text { sem ser eliminado. No }\end{array}$ & \\
& & $\begin{array}{l}\text { fim do jogo, a equipe } \\
\text { com maior número de } \\
\text { corridas ganha. (beisebol) } \\
\text { (Esporte) }\end{array}$ & \\
\hline
\end{tabular}

\begin{tabular}{|l|l|l|l|}
\hline Palavra & Etimologia provável & Significado & Fonte \\
\hline $\begin{array}{l}\text { Sírkulo di mei } \\
\text { mei } \\
\text { ['sixkulo] [di] ['mej] } \\
{[\text { 'mej] }}\end{array}$ & $<$ Círculo do meio & $\begin{array}{l}\text { Área central do campo de } \\
\text { futebol (Esporte) }\end{array}$ & C2010: 11 \\
\hline
\end{tabular}

890.

\begin{tabular}{|l|l|l|l|}
\hline Palavra & Etimologia provável & Significado & Fonte \\
\hline $\begin{array}{l}\text { Zjurnalismo }^{\mathbf{2 5 4}} \\
\text { [3ohna'lismo] }\end{array}$ & $<$ Jornalismo & Jornalismo (Tecnologia e & RH2008: \\
& & Desenvolvimento) & 195 \\
\hline
\end{tabular}

\begin{tabular}{|l|l|l|l|}
\hline 891. & Etimologia provável & Significado & Fonte \\
\hline $\begin{array}{l}\text { Zjurnalista } \\
\text { [3ohna'lista }\end{array}$ & $<$ Jornalista & $\begin{array}{l}\text { Jornalista (Tecnologia e } \\
\text { Desenvolvimento) }\end{array}$ & $\begin{array}{l}\text { RH2008: } \\
195\end{array}$ \\
\hline
\end{tabular}

\section{FRANCÊS}

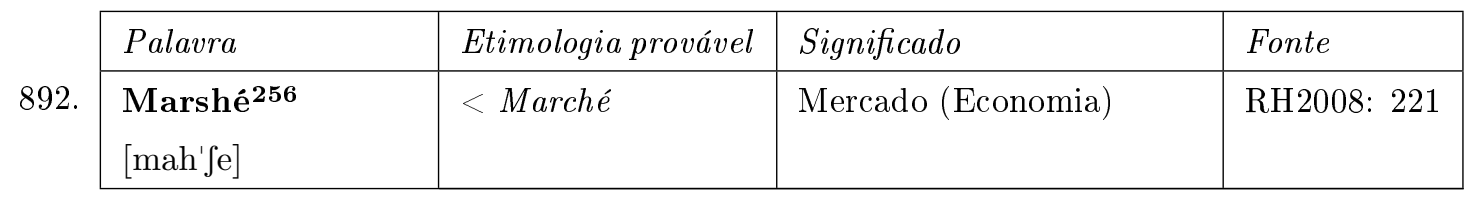

\section{ESPANHOL/HOLANDÊS}

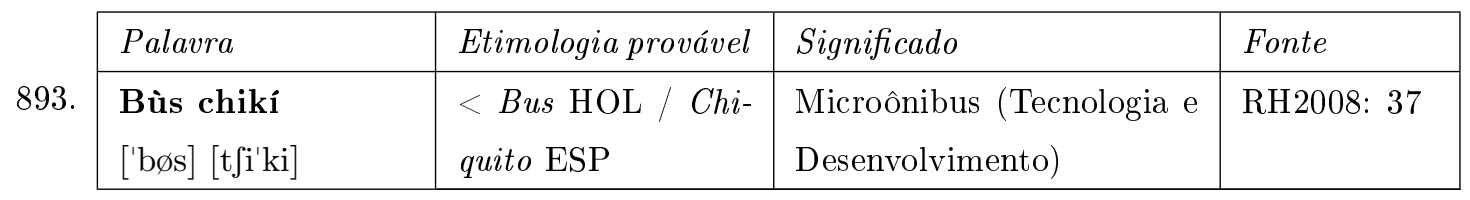

254 Varia com periodismo ${ }_{188}$.

255 Varia com periodista $a_{189}$ e notisiero $_{178}$.

256 Varia com merkado ${ }_{734}$ e waf 957. 
894.

\begin{tabular}{|c|c|c|c|}
\hline Palavra & Etimologia provável & Significado & Fonte \\
\hline $\begin{array}{l}\text { Mashin di feita } \\
{[\text { ma'fĩ] [di] ['fejta] }}\end{array}$ & $\begin{array}{l}\Leftarrow \text { Machine } \mathrm{HOL} / \\
\text { Afeitar ESP }\end{array}$ & $\begin{array}{l}\text { Barbeador (máquina) } \\
\text { (Tecnologia e Desenvolvi- } \\
\text { mento) }\end{array}$ & $\begin{array}{l}\text { RH2008: } \\
163\end{array}$ \\
\hline
\end{tabular}

895.

\begin{tabular}{|l|l|l|l|}
\hline Palavra & Etimologia provável & Significado & Fonte \\
\hline Mashin di kose & $\Leftarrow$ Mashin HOL / & Máquina de costura & RH2008: \\
[ma'ji] [di] ['kose] & Coser ESP & $\begin{array}{l}\text { Tecnologia e Desenvolvi- } \\
\text { mento) }\end{array}$ & 163 \\
& & & \\
\hline
\end{tabular}

896.

\begin{tabular}{|l|l|l|l|}
\hline Palavra & Etimologia provável & Significado & Fonte \\
\hline $\begin{array}{l}\text { Preis di ganga } \\
\text { ['prejs] [di] ['gãga] }\end{array}$ & $<$ Prejs HOL / & Preço irrisório (Economia) & RH2008: \\
& Ganga ESP & & 87 \\
\hline
\end{tabular}

897.

\begin{tabular}{|l|l|l|l|}
\hline Palavra & Etimologia provável & Significado & Fonte \\
\hline $\begin{array}{l}\text { Preis di kosto } \\
\text { ['prjs] [di] ['kosto] }\end{array}$ & $\begin{array}{l}<\text { Prijs HOL / } \\
\text { Costo ESP }\end{array}$ & Preço de custo (Economia) & HH88: 40 \\
\hline
\end{tabular}

898.

\begin{tabular}{|l|l|l|l|}
\hline Palavra & Etimologia provável & Significado & Fonte \\
\hline $\begin{array}{l}\text { Promé-minister } \\
{[\text { pro'me }][\text { mi'nistch }]}\end{array}$ & $\begin{array}{l}\text { Minister HOL } \\
\text { Primer ESP / }\end{array}$ & $\begin{array}{l}\text { Primeiro-ministro (Polí- } \\
\text { tica) }\end{array}$ & EX2011: 05 \\
\hline
\end{tabular}

\begin{tabular}{|l|l|l|l|}
\hline Palavra & Etimologia provável & Significado & Fonte \\
\hline $\begin{array}{l}\text { Stashon di gaso- } \\
\text { lin Estación ESP / } \\
{[\text { esta'fõ }]} \\
{[\text { gaso'lî] }]}\end{array}$ & $\begin{array}{l}<\text { Posto de gasolina } \\
\text { Gasoline HOL }\end{array}$ & & RH2008:88 \\
\hline
\end{tabular}

\begin{tabular}{|lr|l|l|l|}
\hline 900. & Etimologia provável & Significado & Fonte \\
\hline $\begin{array}{l}\text { Tiramentu } \\
\text { speer } \\
\text { [tira'mẽtu }]\end{array}$ & di & Tirar $/<$ Speer & $\begin{array}{l}\text { Lançamento de dardo (Es- } \\
\text { porte) }\end{array}$ & EX2011: 10 \\
{$[$ is'pyh $]$} & & & \\
\hline
\end{tabular}

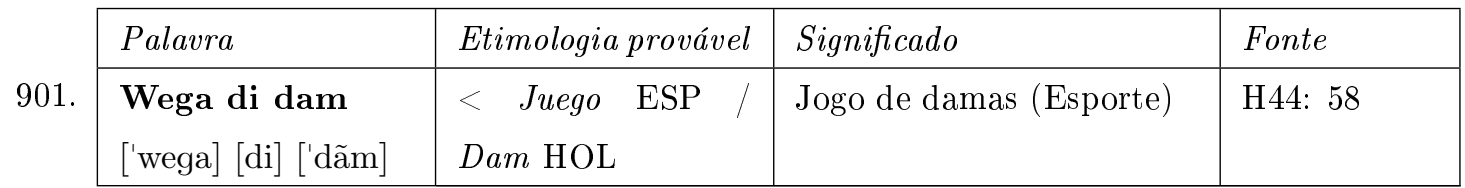

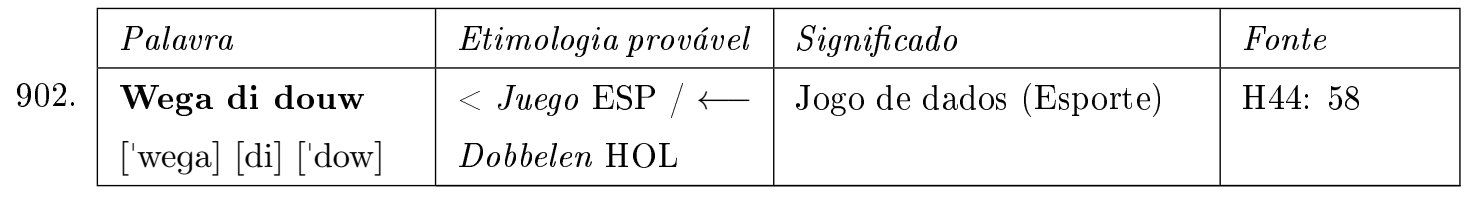


903.

\begin{tabular}{|l|l|l|l|}
\hline Palavra & Etimologia provável & Significado & Fonte \\
\hline Zag di koriente & $<$ Zaag HOL / Cor- & Serra elétrica (Tecnologia e & RH2008: \\
['zah] [di] [ko'rjẽte] & riente ESP & Desenvolvimento) & 282 \\
& & & \\
\hline
\end{tabular}

ESPANHOL/INGLÊS

904.

\begin{tabular}{|l|l|l|l|}
\hline Palavra & Etimologia provável & Significado & Fonte \\
\hline $\begin{array}{l}\text { Liña òf nèt } \\
\text { ['lĩna] [əf] ['nct] }\end{array}$ & $\begin{array}{l}\text { Liña ESP / Of } \\
\text { net ING }\end{array}$ & $\begin{array}{l}\text { Linha de rede (futebol) } \\
\text { (Esporte) }\end{array}$ & H44: 29 \\
\hline
\end{tabular}

905.

\begin{tabular}{|l|l|l|l|}
\hline Palavra & Etimologia provável & Significado & Fonte \\
\hline $\begin{array}{l}\text { Out for regla } \\
\text { ['awt] ['foh] ['regla] }\end{array}$ & $\begin{array}{l}<\text { Out for ING / } \\
\text { Regla ESP }\end{array}$ & Toque com falha (Esporte) & D86: 173 \\
\hline
\end{tabular}

\begin{tabular}{|l|l|l|l|}
\hline Palavra & Etimologia provável & Significado & Fonte \\
\hline Picher Habridor & $<$ Pitcher ING / & $\begin{array}{l}\text { Lançador, que inicia a ação } \\
\text { de cada jogada lançando a } \\
\text { ['pitfer] [habri'do] }\end{array}$ & Abridor ESP \\
& & $\begin{array}{l}\text { Eola sobre a casa base onde } \\
\text { o batedor estará preparado } \\
\text { para bater (beisebol) (Es- } \\
\text { porte) }\end{array}$ & \\
\hline
\end{tabular}

\begin{tabular}{|l|l|l|l|l|}
\hline 907. & Palavra & Etimologia provável & Significado & Fonte \\
\cline { 2 - 4 } & $\begin{array}{l}\text { Wega di floret } \\
\text { ['wega] [di] [flo'set] }\end{array}$ & $\begin{array}{l}<\text { Juego ESP / Flo- } \\
\text { ret } \text { ING }\end{array}$ & Esgrima (Esporte) & H44: 58 \\
\hline
\end{tabular}

\section{ESPANHOL/PORTUGUÊS}

908

\begin{tabular}{|l|l|l|l|}
\hline Palavra & Etimologia provável & Significado & Fonte \\
\hline $\begin{array}{l}\text { Liña di mei mei } \\
[' \text { 'ĩna }] \text { [di }] \quad[\text { 'mej] }] \\
{[\text { 'mej] }}\end{array}$ & PORT & $\begin{array}{l}\text { Linha do meio (futebol) } \\
\text { (Esporte) }\end{array}$ & C2010: 11 \\
\hline
\end{tabular}

HOLANDÊS + ESPANHOL/PORTUGUÊS

909.

\begin{tabular}{|l|l|l|l|}
\hline Palavra & Etimologia provável & Significado & Fonte \\
\hline $\begin{array}{l}\text { Bòm atómiko } \\
\text { [bõa'tõmiko] }\end{array}$ & $\begin{array}{l}<\text { Bom HOL, Atô- } \\
\text { mico PORT / Ató- } \\
\text { mico ESP }\end{array}$ & $\begin{array}{l}\text { Bomba atômica (Tecnolo- } \\
\text { gia e Desenvolvimento) }\end{array}$ & RH2008: 33 \\
\hline
\end{tabular}

257 Varia com esgrima 616 .

258 Varia com atombòm ${ }_{256}$. 
910.

\begin{tabular}{|l|l|l|l|}
\hline Palavra & Etimologia provável & Significado & Fonte \\
\hline Hür di edifisio & $<$ Huur HOL, Edi- & Seguro domiciliar (Econo- & EX2011: 05 \\
['hyr] [di] [edi'fisio] & fício PT / Edificio & mia) & \\
& ESP & & \\
\hline
\end{tabular}

911.

\begin{tabular}{|l|l|l|l|}
\hline Palavra & Etimologia provável & Significado & Fonte \\
\hline Karchi di kastigu & $<$ Kaart HOL / & Cartão de penalidade (fu- & C2010: 17 \\
['kaht]i] [di] & Castigo ESP/POR & tebol) (Esporte) & \\
{$[$ kas'tigu $]$} & & & \\
\hline
\end{tabular}

912.

\begin{tabular}{|c|c|c|c|}
\hline Palavra & Etimologia provável & Significado & Fonte \\
\hline $\begin{array}{l}\text { Mashin di habri } \\
\text { palu } \\
{[\text { ma' [ñ [di] ['habri }]}\end{array}$ & $\begin{array}{l}<\text { Machine } \mathrm{HOL} \\
/ \quad \text { Abrir, } \\
\text { ESP } / \mathrm{POR}\end{array}$ & $\begin{array}{l}\text { Serra circular (Tecnologia } \\
\text { e Desenvolvimento) }\end{array}$ & $\begin{array}{l}\text { RH2008: } \\
163\end{array}$ \\
\hline
\end{tabular}

913.

\begin{tabular}{|l|l|l|l|}
\hline Palavra & Etimologia provável & Significado & Fonte \\
\hline Mashin di konta & $\Leftarrow$ Machine HOL / & Calculadora (Tecnologia e & RH2008: \\
[ma'Jĩ] [di] ['kõta] & Conta ESP/POR & Desenvolvimento) & 163 \\
& & & \\
\hline
\end{tabular}

\begin{tabular}{|l|l|l|l|}
\hline Palavra & Etimologia provável & Significado & Fonte \\
\hline Mashin di kòrta & $\Leftarrow$ Machine HOL & Cortador de relva (Tecno- & RH2008: \\
yerba & $/$ Cortar relva & logia e Desenvolvimento) & 163 \\
$\begin{array}{l}\text { [ma'Sĩ] [di] ['kohta] } \\
\text { ['jehba] }\end{array}$ & ESP/POR & & \\
\hline
\end{tabular}

\begin{tabular}{|l|l|l|l|}
\hline Palavra & Etimologia provável & Significado & Fonte \\
\hline Mashin di laba & $\Leftarrow$ Machine HOL & Máquina de lavar (Tecno- & RH2008: \\
paña 259 & $/$ Lavar paño & logia e Desenvolvimento) & 163 \\
{$\left[\begin{array}{l}\text { ma'Jĩ] [di] [nlaba] } \\
\text { [npãna] }\end{array}\right.$} & ESP/POR & & \\
\hline
\end{tabular}

916

\begin{tabular}{|l|l|l|l|}
\hline Palavra & Etimologia provável & Significado & Fonte \\
\hline $\begin{array}{l}\text { Pòst aéreo } \mathbf{2 6 0} \\
\text { [posta'rerio] }\end{array}$ & $\begin{array}{l}\text { Post HOL / Aé- } \\
\text { reo ESP/POR }\end{array}$ & Correio aéreo (Tecnologia e & RH2008: \\
& & Desenvolvimento) & 203 \\
\hline
\end{tabular}

259 Varia com wasmashin 404.

260 Varia com lùgtpòst ${ }_{319}$. 


\begin{tabular}{|c|c|c|c|c|}
\hline \multirow[b]{2}{*}{917.} & Palavra & Etimologia provável & Significado & \multirow{2}{*}{$\begin{array}{l}\text { Fonte } \\
\text { HH88: } 35\end{array}$} \\
\hline & $\begin{array}{l}\text { Sistema di huur- } \\
\text { koop } \\
\text { [sis'tema] [di] ['hyh- } \\
\text { kop] }\end{array}$ & $\begin{array}{l}<\quad \text { Sistema } \\
\text { ESP/POR } \\
\text { Huurkoop HOL }\end{array}$ & $\begin{array}{l}\text { Sistema de arredamento } \\
\text { (Economia) }\end{array}$ & \\
\hline & Palavra & Etimologia provável & Significado & Fonte \\
\hline 918. & $\begin{array}{l}\text { Zag di habri palu } \\
{[\text { 'zah }] \quad[\text { di }] \quad[\text { 'habri }]} \\
{[\text { 'palu }]}\end{array}$ & $\begin{array}{lcr}< & \text { Zaag } & \text { HOL } \\
/ & \text { Abrir } & \text { pau } \\
\text { ESP } / \text { POR } & \\
\end{array}$ & $\begin{array}{l}\text { Serra (Tecnologia e Desen- } \\
\text { volvimento) }\end{array}$ & EX2011:05 \\
\hline
\end{tabular}

\section{HOLANDÊS/INGLÊS}

\begin{tabular}{|c|c|c|c|c|}
\hline \multirow[b]{2}{*}{919.} & Palavra & Etimologia provável & Significado & Fonte \\
\hline & $\begin{array}{l}\text { Akrobat } \\
\text { [akro'bat] }\end{array}$ & $\begin{array}{l}<\text { Acrobat ING } \\
\text { Acrobaat HOL }\end{array}$ & Acrobata (Esporte) & RH2008: 5 \\
\hline \multirow[b]{2}{*}{920.} & Palavra & Etimologia provável & Significado & Fonte \\
\hline & $\begin{array}{l}\text { Bowling }^{261} \\
\text { ['bowlĩ] }\end{array}$ & $<$ Bowling & Boliche (Esporte) & P92: 36 \\
\hline
\end{tabular}

\begin{tabular}{|c|c|c|c|c|}
\hline & Palavra & Etimologia provável & Significado & Fonte \\
\hline 921. & $\begin{array}{l}\text { Coach } \\
\left.\text { ['kowt } \int \mathrm{i}\right]\end{array}$ & $<$ Coach & Técnico (Esporte) & C2010: 17 \\
\hline
\end{tabular}

\begin{tabular}{|c|c|c|c|c|}
\hline & Palavra & Etimologia provável & Significado & Fonte \\
\hline 922. & $\begin{array}{l}\text { Croquet }^{262} \\
\text { ['krokst] }\end{array}$ & $<$ Croquet & Críquete (Esporte) & P92: 48 \\
\hline
\end{tabular}

\begin{tabular}{|c|c|c|c|c|}
\hline & Palavra & Etimologia provável & Significado & Fonte \\
\hline 923. & $\begin{array}{l}\text { Floret } \\
\text { [flo'ret] }\end{array}$ & $<$ Floret & $\begin{array}{l}\text { Tipo de espada (esgrima) } \\
\text { (Esporte) }\end{array}$ & OL93: 19 \\
\hline
\end{tabular}

\begin{tabular}{|l|l|l|l|}
\hline Palavra & Etimologia provável & Significado & Fonte \\
\hline $\begin{array}{l}\text { Òfsait } \\
\text { ['ofsajt] }\end{array}$ & $<$ Offside & $\begin{array}{l}\text { Impedimento (futebol) } \\
\text { (Esporte) }\end{array}$ & RH2008: 180 \\
\hline
\end{tabular}

\section{HOLANDÊS/PORTUGUÊS}

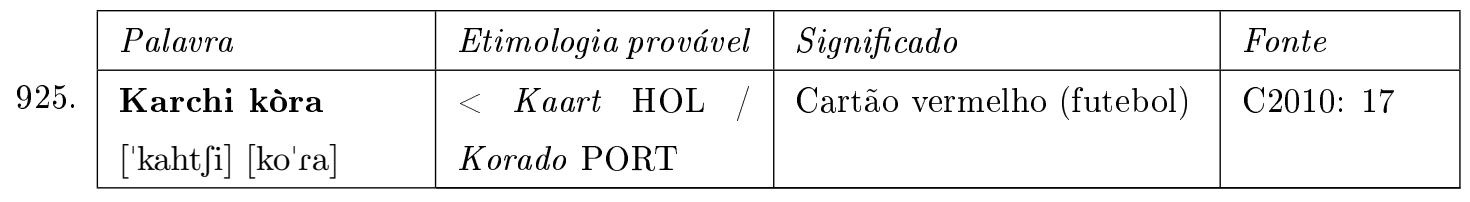

261 Varia com kegel 307 .

262 Varia com kreket ${ }_{156}$. 


\section{HOLANDÊS/SUECO}

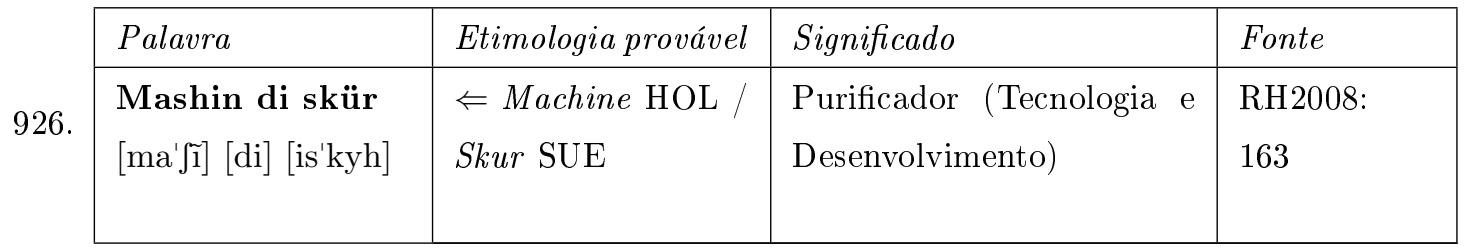

ESPANHOL/PORTUGUÊS + ESPANHOL

\begin{tabular}{|l|l|l|l|}
\hline Palavra & Etimologia provável & Significado & Fonte \\
\hline $\begin{array}{l}\text { Kapital Capital } \\
\text { kribí263 } \\
{[\text { kapi'tat] [inskri'bi] }}\end{array}$ & $\begin{array}{l}\text { Capital emitido (Econo- } \\
\text { mia) }\end{array}$ & HH88: 40 \\
\hline
\end{tabular}

ESPANHOL/PORTUGUÊS + ESPANHOL + HOLANDÊS

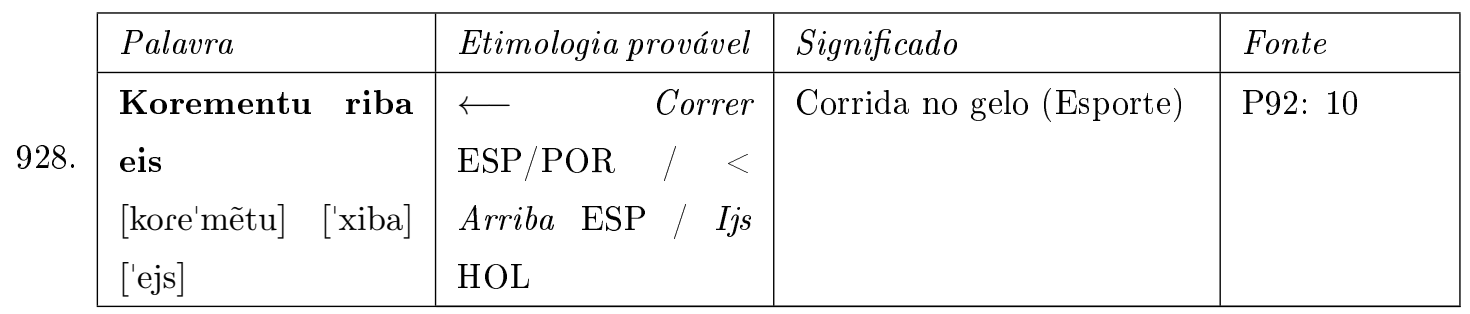

INGLÊS + ESPANHOL/PORTUGUÊS

929.

\begin{tabular}{|l|l|l|l|}
\hline Palavra & Etimologia provável & Significado & Fonte \\
\hline $\begin{array}{l}\text { Step di penalti } \\
\text { [is'tcp }] \quad \text { Step ING, Pế- } \\
{[\text { pe'nałti }]}\end{array}$ & $\begin{array}{l}\text { Área do pênalti (futebol) } \\
\text { nalti PORT / Pe- } \\
\text { nalty ESP }\end{array}$ & (Esporte) & \\
\hline
\end{tabular}

\section{INGLÊS/PORTUGUÊS}

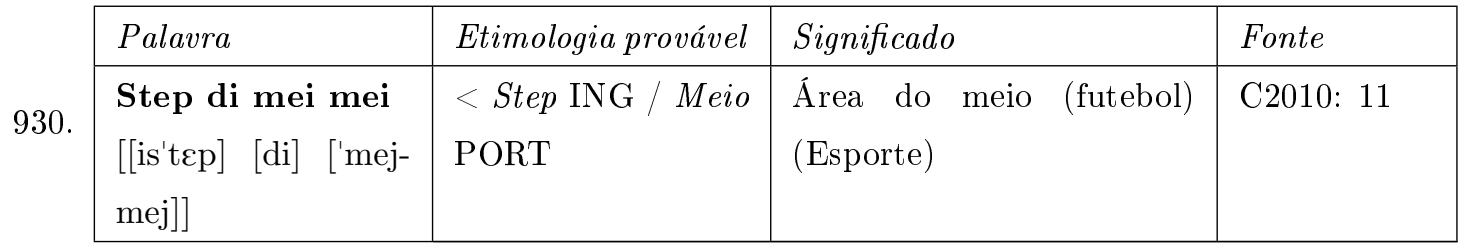

\section{ETIMOLOGIA DESCONHECIDA}

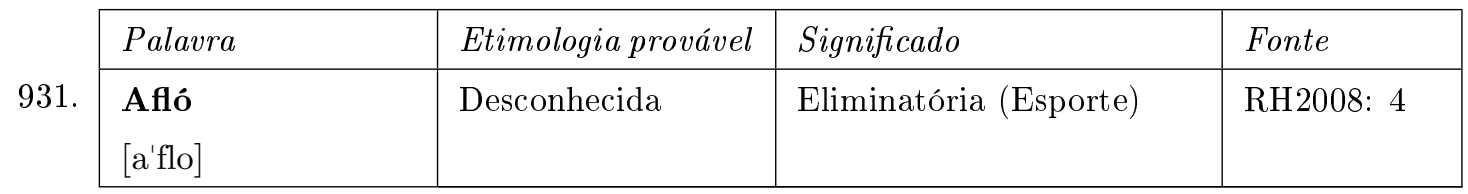

\begin{tabular}{|c|c|c|c|c|}
\hline & Palavra & Etimologia provável & Significado & Fonte \\
\hline 932. & $\begin{array}{l}\text { Aliniashon } \\
\text { [alinia'fõ] }\end{array}$ & Desconhecida & $\begin{array}{lll}\text { Escalação de jogadores } \\
\text { (Esporte) }\end{array}$ & D86: 162 \\
\hline
\end{tabular}

${ }^{263}$ Varia com geplaatst kapitaal ${ }_{291}$. 


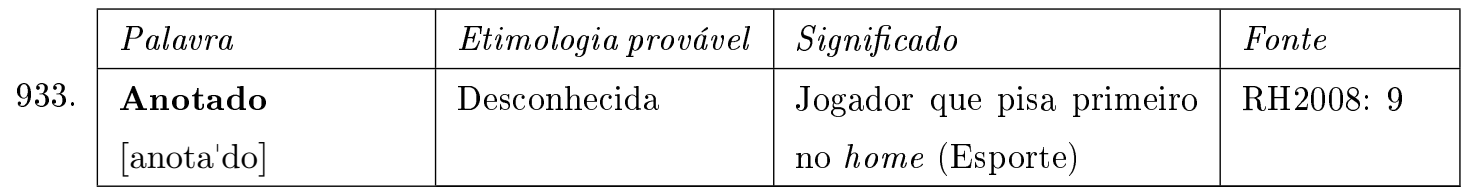

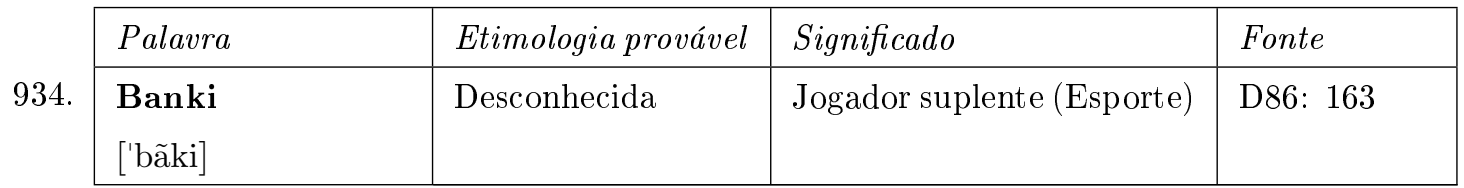

\begin{tabular}{|c|c|c|c|c|}
\hline & Palavra & Etimologia provável & Significado & Fonte \\
\hline 935. & $\begin{array}{l}\text { Bari base } \\
\text { [ba'ri] ['base] }\end{array}$ & Desconhecida & $\begin{array}{l}\text { Tipo de lançamento (Es- } \\
\text { porte) }\end{array}$ & D86: 163 \\
\hline
\end{tabular}

\begin{tabular}{|c|c|c|c|c|}
\hline & Palavra & Etimologia provável & Significado & Fonte \\
\hline 936. & $\begin{array}{l}\text { Bons } \\
\text { ['bõs] }\end{array}$ & Desconhecida & $\begin{array}{l}\text { Movimento específico da } \\
\text { bola no beisebol (Esporte) }\end{array}$ & D86: 164 \\
\hline
\end{tabular}

\begin{tabular}{|l|l|l|l|}
\hline Palavra & Etimologia provável & Significado & Fonte \\
\hline Box & Desconhecida & Local em que o lançador & D86: 164 \\
['bokis] & & $\begin{array}{l}\text { faz seu lançamento (Es- } \\
\text { porte) }\end{array}$ & \\
& & & \\
\hline
\end{tabular}

938.

\begin{tabular}{|l|l|l|l|}
\hline Palavra & Etimologia provável & Significado & Fonte \\
\hline $\begin{array}{l}\text { Bula na awa } \\
\text { ['bula] [na] ['awa] }\end{array}$ & $<$ Desconhecida & $\begin{array}{l}\text { Jogo com bola na água } \\
\text { (Esporte) }\end{array}$ & P92: 48 \\
& & & \\
\hline
\end{tabular}

\begin{tabular}{|c|c|c|c|c|}
\hline & Palavra & Etimologia provável & Significado & Fonte \\
\hline 939. & $\begin{array}{ll}\text { Chalaka den la- } \\
\text { ria } \\
\text { ['tfalaka] } & \\
\text { ['larja] } & \end{array}$ & Desconhecida & $\begin{array}{l}\text { Chute de "bicicleta" em } \\
\text { jogo de futebol (Esporte) }\end{array}$ & C2010: 21 \\
\hline
\end{tabular}

\begin{tabular}{|l|l|l|l|}
\hline Palavra & Etimologia provável & Significado & Fonte \\
\hline $\begin{array}{l}\text { Djul } \\
\text { De4 } \\
\text { ['dzuł }]\end{array}$ & Desconhecida & $\begin{array}{l}\text { Tipo de jogo de amarelinha } \\
\text { (Esporte) }\end{array}$ & RH2008: 58 \\
& & & \\
\hline
\end{tabular}

\begin{tabular}{|c|c|c|c|c|}
\hline & Palavra & Etimologia provável & Significado & Fonte \\
\hline 941. & $\begin{array}{l}\text { Dragbunt } \\
\text { [drah'bãt] }\end{array}$ & Desconhecida & $\begin{array}{l}\text { Toque de bola em beisebol } \\
\text { (Esporte) }\end{array}$ & P92: 27 \\
\hline
\end{tabular}

264 Varia com pele 342. 


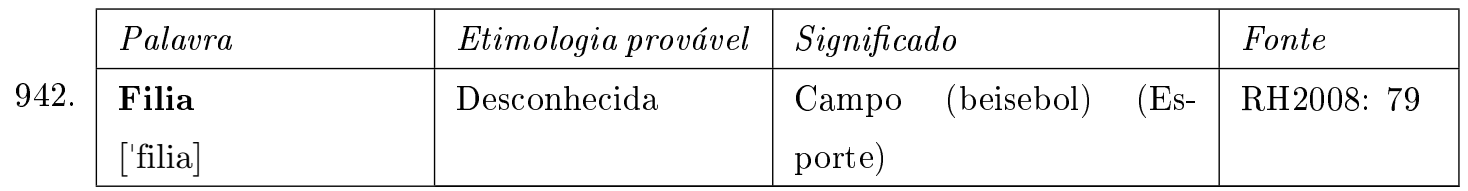

943.

\begin{tabular}{|l|l|l|l|}
\hline Palavra & Etimologia provável & Significado & Fonte \\
\hline $\begin{array}{l}\text { Fungia } \\
\text { ['fũhia] }\end{array}$ & Desconhecida & $\begin{array}{l}\text { Ação de bater a bola para } \\
\text { o treinador (Esporte) }\end{array}$ & D86: 167 \\
\hline
\end{tabular}

\begin{tabular}{|l|l|l|l|}
\hline Palavra & Etimologia provável & Significado & Fonte \\
\hline Fungiado & Desconhecida & $\begin{array}{l}\text { Pessoa que bate a bola } \\
\text { dentro do "out-field" (bei- } \\
\text { sebol) (Esporte) }\end{array}$ & D86: 167 \\
& & (füdo
\end{tabular}

\begin{tabular}{|c|c|c|c|}
\hline Palavra & Etimologia provável & Significado & Fonte \\
\hline $\begin{array}{l}\text { Fungo } \\
\text { ['fũgo] }\end{array}$ & Desconhecida & $\begin{array}{l}\text { Forma de bater a bola (bei- } \\
\text { sebol) (Esporte) }\end{array}$ & D86: 167 \\
\hline
\end{tabular}

\begin{tabular}{|c|c|c|c|}
\hline Palavra & Etimologia provável & Significado & Fonte \\
\hline $\begin{array}{l}\text { Ganashi } \\
{[\text { ga'naji] }}\end{array}$ & Desconhecida & Gasto (Economia) & RH2008: 108 \\
\hline
\end{tabular}

\begin{tabular}{|c|c|c|c|}
\hline Palavra & Etimologia provável & Significado & Fonte \\
\hline $\begin{array}{l}\text { Ganashi bruto } \\
\text { [gã'nãfi] ['bruto] }\end{array}$ & Desconhecida & Gasto bruto (Economia) & HH88: 35 \\
\hline
\end{tabular}

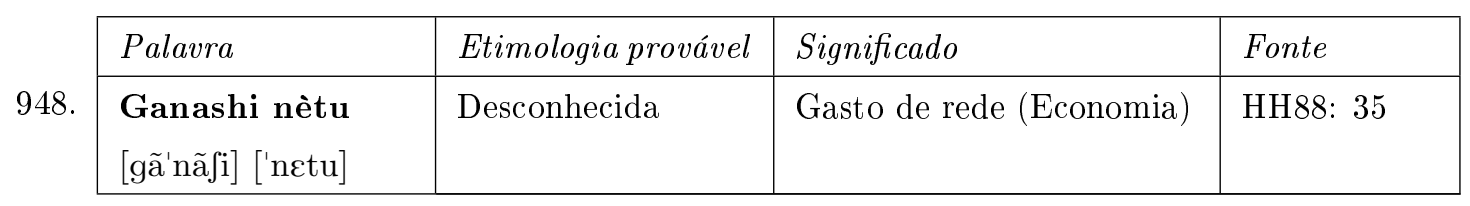

\begin{tabular}{|c|c|c|c|}
\hline Palavra & Etimologia provável & Significado & Fonte \\
\hline $\begin{array}{l}\text { Hila } \\
\text { ['hila] }\end{array}$ & Desconhecida & $\begin{array}{l}\text { Tipo de jogo em que as me- } \\
\text { ninas rodam as saias (Es- } \\
\text { porte) }\end{array}$ & RH2008: 98 \\
\hline
\end{tabular}

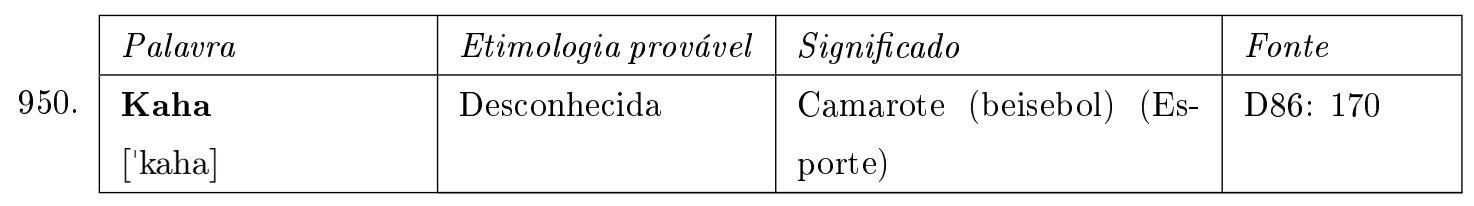




\begin{tabular}{|l|l|l|l|}
\hline Palavra & Etimologia provável & Significado & Fonte \\
\hline Kup & Desconhecida & Protetor da parte delicada & D86: 171 \\
['køp] & & $\begin{array}{l}\text { de um homem, usado em } \\
\text { partidas de beisebol (Es- } \\
\text { porte) }\end{array}$ & \\
& & & \\
\hline
\end{tabular}

\begin{tabular}{|c|c|c|c|}
\hline Palavra & Etimologia provável & Significado & Fonte \\
\hline $\begin{array}{ll}\text { 952. } & \text { Machikon } \\
{[\text { matji'kõ }]}\end{array}$ & Desconhecida & $\begin{array}{l}\text { Quando o jogador não faz } \\
\text { bom contato com a bola } \\
\text { (beisebol) (Esporte) }\end{array}$ & D86: 172 \\
\hline
\end{tabular}

\begin{tabular}{|l|l|l|l|}
\hline Palavra & Etimologia provável & Significado & Fonte \\
\hline S53. & Desconhecida & Poupança, caixa (Econo- & RH2008: 227 \\
['sãm] & mia) & & \\
\hline
\end{tabular}

\begin{tabular}{|c|c|c|c|c|}
\hline & Palavra & Etimologia provável & Significado & Fonte \\
\hline 954. & $\begin{array}{l}\text { Shóbel }^{266} \\
\text { ['`วbદł] }\end{array}$ & Desconhecida & Embaralhar (Esporte) & D86: 175 \\
\hline
\end{tabular}

\begin{tabular}{|l|l|l|l|}
\hline Palavra & Etimologia provável & Significado & Fonte \\
\hline Tribey & Desconhecida & Jogador bate a bola pra & D86: 176 \\
terceira base (beisebol) & \\
['tribi] & & (Esporte) & \\
& & & \\
\hline
\end{tabular}

\begin{tabular}{|c|c|c|c|}
\hline Palavra & Etimologia provável & Significado & Fonte \\
\hline $\begin{array}{l}\text { Twobey } \\
\text { ['towbi] }\end{array}$ & Desconhecida & $\begin{array}{l}\text { Jogador bate a bola pra se- } \\
\text { gunda base (beisebol) (Es- } \\
\text { porte) }\end{array}$ & D86: 176 \\
\hline
\end{tabular}

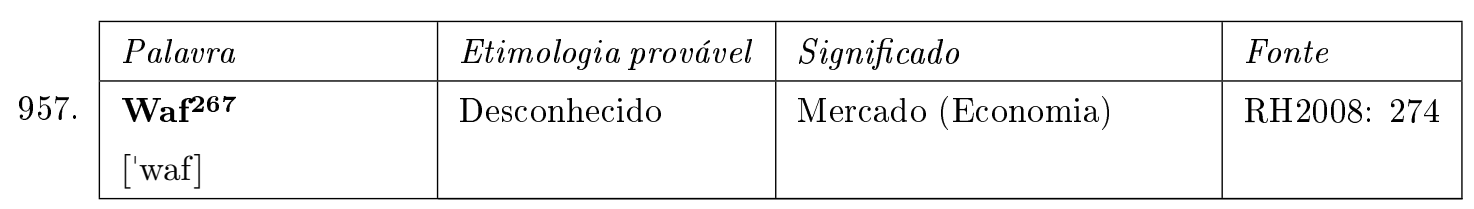

\footnotetext{
265 Varia com ahoro $_{8}$ e spar $_{375}$.

266 Varia com barahá ${ }_{32}$.

267 Varia com marshé 892 e waf 957 .
} 